$$
\operatorname{Pontifícia~}_{\text {Universidade }} \text { Católica }_{\text {do Rio daneiro }}
$$

Allane de Souza Pedrotti Matos

\title{
"ACABOU A QUALIDADE DA ESCOLA": CONSTRUÇÃO DE ESTIGMA EM NARRATIVAS SOBRE COTAS DE INGRESSO NO CEFET/RJ
}

\section{Tese de Doutorado}

Tese apresentada como requisito parcial para obtenção do grau de Doutor pelo Programa de Pósgraduação em Estudos da Linguagem do Departamento de Letras da PUC-Rio.

Orientadora: Profa. Liana de Andrade Biar 


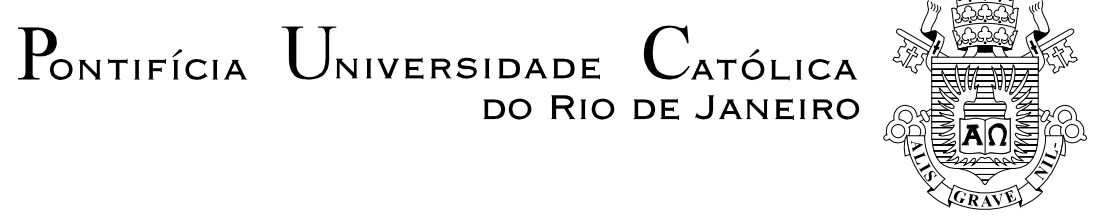

Allane de Souza Pedrotti Matos

\begin{abstract}
"Acabou a Qualidade da Escola": Construção de Estigma em Narrativas sobre Cotas de Ingresso no CEFET/RJ
\end{abstract}

Tese apresentada como requisito parcial para obtenção do grau de Doutor pelo Programa de PósGraduação em Estudos da Linguagem da PUC-Rio. Aprovada pela Comissão Examinadora abaixo.

Profa. Liana de Andrade Biar

Orientadora e Presidente

Departamento de Letras - PUC-Rio

Profa. Adriana Nogueira Accioly Nóbrega

Departamento de Letras - PUC-Rio

Profa. Maria Cristina Giorgi

CEFET/RJ

Prof. Georg Walter Wink

Universidade de Copenhague

Prof. Fabio Sampaio de Almeida

CEFET/RJ

Rio de Janeiro, 30 de abril de 2020 
Todos os direitos reservados. É proibida a reprodução total ou parcial do trabalho sem autorização da universidade, da autora e do orientador.

\section{Allane de Souza Pedrotti Matos}

Graduada em Pedagogia pela UFRJ em 2007. Mestre em Sistemas de Gestão (área de concentração Gestão do Conhecimento) pela UFF em 2014. Realizou Doutoramento Sanduíche na Dinamarca, University of Copenhagen, pela CAPES, onde desenvolveu pesquisa e ministrou disciplina para a graduação como professora convidada. Atualmente compõe a equipe de Coordenação Pedagógica do Ensino Profissional Técnico de Nível Médio do CEFET/RJ, Unidade Maracanã, onde é servidora desde 2009.

Ficha Catalográfica

Matos, Allane de Souza Pedrotti

"Acabou a qualidade da escola" : construção de estigma em narrativas sobre cotas de ingresso no CEFET/RJ / Allane de Souza Pedrotti Matos ; orientadora: Liana de Andrade Biar. - 2020.

212 f. : il. color. ; $30 \mathrm{~cm}$

Tese (doutorado)-Pontifícia Universidade Católica do Rio de Janeiro, Departamento de Letras, 2020.

Inclui bibliografia

1. Letras - Teses. 2. Linguística aplicada. 3. Análise de narrativa. 4. Narrativa. 5. Estigma. 6. Sistema de avaliatividade. I. Biar, Liana de Andrade. II. Pontifícia Universidade Católica do Rio de Janeiro. Departamento de Letras. III. Título. 
À minha filha, Maria Luíza.

Foi por você, é por você e sempre será por você. 


\section{Agradecimentos}

À minha querida orientadora Liana Biar, responsável pelo meu crescimento acadêmico, pela paciência com meus lentos aprendizados, desesperos e lamentações, para além desta pesquisa e tese.

À Cristina Giorgi, por ter me apresentado o NAVIS e ter me levado pela mão para este caminho que amei ter percorrido.

Às professoras do PPGEL, em especial Adriana Nóbrega, Liliana Bastos e Inês Miller, por tanta inspiração, reflexão e carinho nas aulas e fora delas. À Chiquinha, pela atenção, carinho e todas as ajudas.

Ao professor Georg Wink, pelo acolhimento, carinho e ajudas infinitas em Copenhague e orientação e supervisão da pesquisa. À professora Ana Rita Mota, pela parceria e companheirismo dentro e fora da Universidade de Copenhague.

Ao José Cláudio Teixeira, por todos os cuidados, preocupações e por me formar dentro do CEFET/RJ. À Clara Alves, que me criou dentro do CEFET/RJ e se empenha em me fazer sentir um mulherão que conquista o mundo.

Ao pai da minha filha, Guilherme Matos, pelo companheirismo incondicional, e à família Matos, que para sempre será minha também, por toda a ajuda neste processo.

À minha irmã, Alline Pedrotti, e minha tia Gloria Regina, pelo companheirismo e revisões e traduções dos textos, conteúdos e conversas. À minha mãe, Leilane Pedrotti, in memoriam, por ter me ensinado a ser uma mulher enorme. Ao meu pai, Allan Pedro, pela minha criação para a persistência e luta.

À minha filha, Maria Luíza, pela doação de amor e carinhos infinitos e gratuitos, pela paciência com minhas ausências e pelo companheirismo, mesmo sendo uma criança.

Ao CEFET/RJ, pelos auxílios e autorizações concedidos, aos alunos e aos colegas professores que colaboraram para esta pesquisa.

À CAPES e à PUC-Rio, pelos auxílios concedidos, sem os quais este trabalho não poderia ter sido realizado.

À Universidade de Copenhague e seus funcionários, pelos convites, aceites, cuidados e acolhimentos para que minha atuação profissional fosse valorizada e confortável.

O presente trabalho foi realizado com apoio da Coordenação de Aperfeiçoamento de Pessoal de Nível Superior - Brasil (CAPES) - Código de Financiamento 001 


\section{Resumo}

Pedrotti, Allane de Souza; Biar, Liana de Andrade. "Acabou a qualidade da escola": Construção de estigma em narrativas sobre cotas de ingresso no CEFET/RJ. Rio de Janeiro, 2020. 212 p. Tese (Doutorado em Estudos da Linguagem) - Departamento de Letras, Pontifícia Universidade Católica do Rio de Janeiro.

O objetivo desta tese de doutorado é analisar, nas construções discursivas dos docentes do CEFET/RJ, como o estigma de "cotista" é criado, negociado ou desafiado pelos integrantes da instituição. Para dar conta da articulação entre os conceitos propostos na pesquisa e o objetivo principal, esta proposta geral se desdobrou em questões específicas sobre: quais recursos lexicogramaticais e discursivos, nas narrativas docentes, se relacionam ao estigma das cotas e os negociam; a quais sistemas de coerência os docentes se afiliam; e quais estratégias retóricas os docentes utilizam para criação, manipulação, manutenção, resistência, subversão, etc. dos sistemas de coerência sobre cotas. Para tanto, a arquitetura teórica desta tese foi baseada na noção de estigma (GOFFMAN, 1988), que orienta esta pesquisa de maneira geral, e apoiada discursivamente na análise de narrativa (LABOV, 1972) combinada à análise crítica do discurso, pelo viés das estratégias retóricas descritas por Ruth Wodak e colaboradores (2009). Ao realizar as análises, foi utilizado o suporte instrumental da Linguística Sistêmico-Funcional (HALLIDAY, 1985) por meio da noção de multifuncionalidade, (REZENDE \& RAMALHO, 2006) e do Sistema de Avaliatividade (MARTIN; WHITE, 2005; NÓBREGA, 2009; WHITE, 2004), de modo que as estratégias de Wodak $e$ colaboradores. fossem entrelaçadas, para o embasamento das descrições, aos itens lexicogramaticais de avaliação identificados nas narrativas. Ao final das análises, foi possível identificar o sistema de coerência da meritocracia, representado especificamente nas metáforas de esforço individual, de escada para o sucesso e posse das vagas públicas a determinado setor da sociedade, no qual não se encontram os próprios cotistas. Esse sistema apareceu por intermédio dos itens lexicogramaticais de avaliação, que são índices textuais de uma série de expectativas, pressuposições e preconceitos que instanciam os estigmas para os alunos que acessam o CEFET/RJ pela política de cotas. Entender como esses 
estigmas são criados é relevante não só para a instituição estudada em si, mas para a sociedade em geral. O Discurso presente nas narrativas sobre cotas deslegitima a política de cotas como um todo no Brasil, mitigando a força e a importância das políticas afirmativas brasileiras, especialmente no cenário político atual. Por esse motivo, os resultados desta tese são fundamentais para se repensar o engajamento no caminho das cotas no Brasil.

\section{Palavras-Chave}

Narrativa; estigma; políticas afirmativas; cotas raciais; educação brasileira. 


\section{Abstract}

Pedrotti, Allane de Souza; Biar, Liana de Andrade (Advisor). "The school's quality is over": Stigmas construction in admission quota's narratives in CEFET/RJ. Rio de Janeiro, 2020. 212 p. Tese de Doutorado Departamento de Letras, Pontifícia Universidade Católica do Rio de Janeiro.

The objective of this doctoral thesis is to analyze, in the discursive constructions of CEFET / RJ professors, how the stigma of "quota holder" is created, negotiated or challenged by the members of the institution. In order to accomplish the articulation between the concepts proposed in the research and the main objective, this general proposal unfolded in specific questions about which grammatical and linguistic lexical resources, in the teaching narratives, are related to the stigmas of quotas and negotiate them; to which systems of coherence the teachers are affiliated to; and what rhetorical strategies teachers use for creation, manipulation, maintenance, resistance, subversion, etc. of quota coherence systems. To this end, the theoretical architecture of this thesis is based on the notion of stigma (GOFFMAN, 1988), that guides this research in a general manner, and discursively supported in the narrative analysis (LABOV, 1972) combined with critical discourse analysis, through the rhetorical strategy bias described by Wodak et al. (2009). When performing the analyses, the instrumental support of Systemic Functional Linguistics (HALLIDAY, 1985) was used, through the notion of multifunctionality (REZENDE \& RAMALHO, 2006), and the Evaluative System (MARTIN; WHITE, 2005; WHITE, 2004; NÓBREGA, 2009) so that the strategies of Wodak et al. (2009) were intertwined, to build the basis of the descriptions, with the lexicogrammatical evaluation items identified in the narratives. At the end of the analyses, it was possible to identify the meritocracy coherence system, specifically the aspect that brings metaphors of individual effort, climbing the ladder to success and possession of public vacancies to a certain sector of society other than where the quota students themselves are. This system appeared through lexicogrammatical evaluation items that are textual indices of a series of expectations, assumptions and prejudices that instantiate the stigmas for students who access CEFET/RJ using quota policy. To comprehend how these stigmas are 
created is relevant not only to the institution in question, but to the society in general. The Discourse present in the narratives about quotas delegitimizes the whole quota policy in Brazil, mitigating the strength and the importance of Brazilian affirmative policies, especially in the current political scenario. For this reason, the results of this thesis are fundamental to rethink the engagement on the path of quotas in Brazil.

\section{Keywords}

Narrative; stigma; affirmative policies; racial quotas; brazilian education. 


\section{Sumário}

1 Introdução

2 O CEFET/RJ, as cotas e a pesquisadora

3 Posicionamento metodológico e contexto de pesquisa

3.1 Por que olhar a microinteração nesta pesquisa? 40

3.2 Explicando melhor o cunho (auto)etnográfico 41

$3.3 \mathrm{O}(\mathrm{meu})$ local de fala 42

3.4 Procedimentos de pesquisa 44

3.4.1 Geração de dados $\quad 44$

3.4.1.1 Seleção dos participantes $\quad 45$

3.4.1.2 Entrevistas $\quad 47$

3.4.1.3 Os participantes das entrevistas $\quad 48$

3.4.2 Procedimentos de análise 49

3.4.2.1 Transcrição dos dados 49

3.4.2.2 Caracterização geral dos dados $\quad 50$

3.4.3 Recorte analítico e categorias selecionadas 51

3.5. Questões éticas e políticas da pesquisa 54

4 Fundamentação teórica $\quad 57$

4.1 Narrativa e as (re)construções sociais e pessoais 58

4.2 Os sistemas de coerência das ordens sociais 61

$4.3 \mathrm{O}$ estigma por Goffman e os estigmas sobre cotas 63

4.4 O Sistema de Avaliatividade 65

4.5 Estratégias retóricas a partir de Wodak et al. 69

4.6 A Meritocracia e a manutenção de uma poderosa ordem social 73

4.7 Encaminhamentos 82 
5 Como os estigmas são construídos discursivamente nas narrativas

5.1 Narrativas de transferência de culpa ou responsabilidade

5.1.1 Conclusões da seção

5.2 Narrativas de trivialização das discriminações

5.2.1 Conclusões da seção

5.3 Narrativas de engajamento docente

5.3.1 Conclusões da seção

5.4 Narrativas de conservação do velho modelo

5.4.1 Conclusões da seção

5.5 Narrativas de descrédito dos alunos e da política de cotas

5.5.1 Conclusões da seção

5.6 Narrativas de descontinuação da política de cotas

5.6.1 Conclusões da seção

5.7 Conclusões do capítulo

6 Considerações Finais

6.1 Aplicações e implicações

6.2 Limitações

6.3 Caminhos futuros

7 Referências bibliográficas 


\section{Lista de figuras}

Figura 1 Antes e depois das cotas 150

Figura 2 Cartaz exposto em um dos acessos principais do 187 CEFET/RJ 


\section{Lista de quadros}

Quadro 1 Modificações de nomes ao longo do centenário de existência do atual CEFET/RJ

Quadro 2 Organização visual resumida do Sistema de

Avaliatividade

Quadro 3 Terminologias adaptadas de estratégias discursivas segundo Wodak et al. (2009) 


\section{Lista de esquemas}

Esquema 1 Distribuição de cotas no CEFET/RJ, conforme 24 regimento da Lei $12.711 / 2012$

Esquema 2 Desenho da arquitetura teórico-metodológica da tese 57

$\begin{array}{lll}\text { Esquema } 3 \text { Relação entre estigmas, narrativas e modos de } & 114\end{array}$ realização discursiva

$\begin{array}{lll}\text { Esquema } 4 \text { Relação entre estigmas, narrativas e modos de } & 124\end{array}$ realização discursiva

Esquema 5 Relação entre estigmas, narrativas e modos de realização discursiva

Esquema 6 Relação entre estigmas, narrativas e modos de realização discursiva

Esquema 7 Relação entre estigmas, narrativas e modos de realização discursiva

Esquema 8 Relação entre estigmas, narrativas e modos de realização discursiva

Esquema 9 Ciclo dos principais estigmas

Esquema 10 Organização da construção discursiva de índices sobre "cotista" 


\section{Lista de tabelas e organograma}

Tabela 1 Caracterização dos dados/alunos 50

Tabela $2 \quad$ Caracterização dos dados/docentes/equipe 51 pedagógica

Organograma 1 Organização hierárquica do Departamento de 31 Ensino Médio e Técnico 


\section{Lista de excertos}

Excerto 1 "eles mesmos se punem, eles se jubilam" 87

Excerto 2 "eles tiveram uma experiência de alunos de $1^{\text {a }}$ qualidade" 89

$\begin{array}{lll}\text { Excerto } 3 \text { "falta educação" } & 91\end{array}$

Excerto 4 "a gente sempre teve problema do garoto que era carente" 94

Excerto 5 "nós ficávamos em pânico" 96

$\begin{array}{lll}\text { Excerto } 6 \text { "levei um susto" } & 97\end{array}$

Excerto 7 "com certeza ela resgata muitos alunos" 100

Excerto 8 "pra você ver né o ponto que a gente chega" 101

Excerto 9 "ele levantou pra partir pra cima de mim" 103

Excerto 10 "bem bem bicho do mato" 104

Excerto 11 “eles não iam aguentar” 105

Excerto 12 "mais gente que tava entendendo menos o que eu estava 107 falando"

Excerto 13 "não tava acostumado a anotar nada na sala de aula" 110

Excerto 14 "eles mesmos se punem, eles se jubilam" 116

Excerto 15 "mas isso foi um caso pontual" 117

Excerto 16 "as turmas estão mais coloridas" 119

Excerto 17 "o aluno que eu recebo ele vem mudando" 121

Excerto 18 "com a cota a gente tem hoje mais afrodescendentes na 122 sala"

Excerto 19 “a gente não vai conseguir resgatar" 125

Excerto 20 "eles não tinham referência nenhuma em casa" 128

Excerto 21 "a gente se articula de todas as formas" 131

Excerto 22 "a gente se une não é na felicidade, eu acho que é no 133 desespero"

Excerto 23 "essas preocupações a gente teve" 136

Excerto 24 "eu acho que a política de cotas como política é um 140 fracasso"

Excerto 25 "o pessoal sem interesse" 141

Excerto 26 "foi justamente o que aconteceu" 144 
Excerto 27 "eu esperava que ia ser um arraso, que ia ser uma avalanche"

Excerto 28 "a gente esperar qualquer coisa" 147

Excerto 29 “jamais pensei lidar" 149

Excerto 30 "eles tiram a vaga de alguém" 151

Excerto 31 "ele tá lutando contra a maré" 155

Excerto 32 "há um muro invisível" 158

Excerto 33 "isso é muito pior do que não entrar" 161

Excerto 34 "era o grande mal que a gente estaria fazendo colocando 164 o aluno aqui"

Excerto 35 "o cara não sabe nem fazer conta e tá aqui no cefet" 165

Excerto 36 "salvar aqueles que quase não têm chance nenhuma" 166

Excerto 37 "mesmo que ele bata a cabeça pra lá e pra cá" 167

Excerto 38 "bacana pro cotista, pro não cotista, se ferrou" 169

Excerto 39 "ele é muito mais educado hoje" 170

Excerto 40 "ele se acostumou com o aluno nota dez" 174

Excerto 41 "pra mim não alterou nada" 176

Excerto 42 "foi um aprendizado eu acho que pra todo mundo" 177

$\begin{array}{ll}\text { Excerto } 43 \text { "você tem que nivelar" } & 178\end{array}$ 
É impossível falar sobre história única sem falar de poder. Há uma palavra, uma palavra da tribo Igbo, que eu lembro sempre sobre as estruturas de poder do mundo, e a palavra é "nkhali". É um substantivo que livremente se traduz: "ser maior que o outro". Como nossos mundos econômicos e políticos, histórias também são definidas pelo princípio do "nkhali". Como são contadas, quem as conta, quando e quantas histórias são contadas, tudo realmente depende do poder. Poder é a habilidade de não só contar a história de outra pessoa, mas de fazê-la a história definitiva daquela pessoa.

(...)

A "única história cria estereótipos". E o problema com estereótipos não é que eles sejam mentira, mas que eles sejam incompletos. Eles fazem uma história tornar-se a única história.

(...)

Histórias importam. Muitas histórias importam.

Chimamanda Ngozi Adichie. TED Talks, 2009. 


\section{Introdução}

"Eu tinha um grupo de amigos no primeiro ano, ainda tenho, mas, enfim, se dissipou... alguns que a maioria era não cotista só tinha eu e mais um colega... ele continuou e eu sentia que tinha um certo preconceito ali porque teve até uma vez que esse meu outro amigo ele foi deixado de lado as pessoas estavam fugindo... assim, era do primeiro ano, as pessoas eram meio infantis e elas ficaram fugindo dele por ele ser cotista, tipo, não queriam estar com ele, não queriam falar com ele nem compartilhar qualquer coisa e eu achei aquilo meio estranho porque era como se, sei lá, não... não fossem todos humanos ali, parecia que eles estavam lidando com um animal, algum tipo de coisa assim e essa experiência... pra mim, ver aquilo foi meio... foi meio perturbador, meio chocante $e$ aconteceu comigo também, mas não foi tão assim porque eu consegui me integrar melhor com eles. E depois de um tempo o preconceito foi diminuindo, mas no começo as pessoas realmente elas falavam mal uma das outras.... os não cotistas falavam mal da gente e isso é... sei lá, era assunto que dava confusão mesmo... era sempre por baixo dos lençóis, ninguém chegava, batia boca na hora, falava assim abertamente, mas sempre teve esse tipo de, assim... atritos entre a gente."

(Trecho da entrevista realizada com Guilherme, aluno participante desta pesquisa.)

Desde a década de 1920, ações afirmativas de inclusão de grupos minoritários ocorrem no mundo, objetivando, para além da inclusão, a diminuição de práticas discriminatórias. Essa noção originou-se na Índia, em 1919, e, segundo Soares (2014, p. 26), "a proposta de ação afirmativa foi criada com o intuito de elaborar uma 'representação diferenciada' dos 'Dalits e Advasis', que pertenciam a uma esfera inferior na sociedade". Nos Estados Unidos, por exemplo, o Ato de Direitos Civis foi alterado em 1964 para garantir o impedimento de toda e qualquer discriminação em instituições educacionais. Aqui no Brasil, em 1968, técnicos do Ministério do Trabalho e do Tribunal Superior de Trabalho pensaram na criação de uma lei que obrigaria as empresas a manter de $10 \%$ a $20 \%$ de empregados negros para solucionar o problema da discriminação racial no mercado de trabalho, mas a lei não é elaborada (SOARES, 2014, p. 28).

Os avanços legislativos no Brasil aconteceram, de fato, quando o Supremo Tribunal Federal sanciona, em 2012, a Lei oㅜ 12.711 (BRASIL, 2012), que garante a reserva de $50 \%$ das vagas para instituições federais de educação superior. Assim como as universidades federais, os institutos federais e as instituições irmãs, como os Centros Federais de Educação Tecnológica (CEFETs), passaram a atender à legislação. A reserva de vagas passou a ser constituinte dos editais para acesso ao Ensino Básico dessas instituições, que abrem processo seletivo para a entrada de alunos no Ensino Médio em todo o Brasil. Apesar da existência 
de iniciativas anteriores, é a Lei o 12.711/2012 (BRASIL, 2012) que finalmente inicia, de forma consistente, uma política de acesso equânime às instituições federais de educação para a população.

O combate às discriminações e inclusão de minorias na sociedade envolve discussões muito mais aprofundadas, incluindo questões dos âmbitos político e social. A princípio, reduziu-se a conquista à questão da reserva de porcentagens de vagas, que a lei traz como um passo positivo para o início desse processo de equidade. Porém, vale abordar aqui a importância de voltar o olhar para além das oportunidades numéricas e entender que a questão da equidade de oportunidades não resolve, em sua gênese, o problema do racismo e de discriminações diversas no Brasil.

São necessárias políticas de esclarecimento histórico-social e conscientização para a sociedade sobre tudo que envolve a cristalização dos sentidos sobre raça e desigualdades sociais no país. O momento político brasileiro mostra o quanto lutas "de minorias" são desrespeitadas por grupos ideológicos opostos e sedimentados nesta sociedade. O respeito, a atenção e empatia sobre situações precárias ou de discriminação de pessoas são indexicalizados como pauta da esquerda política, quando deveriam ser pauta humanitária de qualquer segmento político.

É necessário, por isso, um trabalho profundo de respeito às diferenças, às raças, às classes sociais, aos gêneros e, principalmente, à história do povo brasileiro. É claro que melhorar a democratização do acesso às universidades, empregos e escolas é um dos caminhos, como já se pôde vivenciar ao longo dos anos da Lei de Cotas (BRASIL, 2012). Mas é necessário prestar atenção nos diversos ângulos que envolvem as discriminações para que, de fato, haja alguma modificação social que solidifique novos comportamentos.

A partir dessa mudança de padrão, a equidade de oportunidades passaria a fazer mais sentido. Melhorar a possibilidade de acesso a todos é ainda um passo bastante pequeno, haja vista os problemas que surgem sobre a permanência dos alunos nas instituições. E esse problema de permanência não se dá somente pela falta de recursos materiais ou curriculares de reparação de conteúdos de disciplinas (LEMOS, 2017). As discriminações sofridas pelos alunos nas instituições, a construção dos estigmas sobre eles, as dificuldades acadêmicas criadas para burlar a Lei de Cotas e "filtrar" os alunos após a entrada são exemplos dos obstáculos de permanência que eles enfrentam (BRASIL, 2012; MARQUES, 2018). 
Entendo que esses obstáculos são oriundos do Discurso ${ }^{1}$ do mérito que acaba por dar base e, também, por justificar ações que criam e aumentam as dificuldades dos alunos em suas vidas acadêmicas. Esse Discurso é sacudido com a chegada das políticas afirmativas, em especial pela Lei de Cotas (BRASIL, 2012). Em um país racista como o Brasil, sempre haverá a disputa por espaços e os corpos que não deveriam estar ali seguiram incomodando por muito tempo.

Então, acredito que a resistência ao avanço dos reparos históricos resta à parte da sociedade que segue pelo caminho do desrespeito às dificuldades que as minorias passam em suas vidas. Essa parte da sociedade parece desacreditar no poder do lastro histórico nas vidas das minorias. E não apenas desacredita, como reforça ideais para que seja garantida a manutenção dos danos que o passado causou. As minorias precisam ser incluídas efetivamente na sociedade, tendo o respeito que merecem em todos os âmbitos, e as políticas precisam ter como objetivo a desnaturalização das discriminações que hoje ocorrem no Brasil.

Trago este resumido histórico para sublinhar o fato de a política de cotas ter ganhado impulso nos estudos e em pesquisas sobre o Ensino Superior no Brasil2. Ao ouvir ou falar sobre a política de cotas no Brasil, basicamente vêm à mente as discussões acaloradas que se experimenta em eventos sociais com amigos ou família, quando as histórias que circulam no senso comum parecem tomar conta de um campo de batalha discursivo sobre, principalmente, a meritocracia. $A$ isto se acrescenta, então, o discurso sobre a falta de capacidade de acompanhamento dos cursos, o desperdício da verba pública, o desinteresse e o não merecimento de estudar.

Para uma cultura bacharelista ${ }^{3}$ como a brasileira, o fato de a discussão sobre cotas ter base no contexto de acesso às universidades públicas deixa o campo de disputa ainda mais acirrado. Isso acontece porque essas universidades são foco ou objetivo principal da sociedade de classe média/alta, em detrimento da

\footnotetext{
${ }^{1}$ Nessa tese, e em algumas vertentes de análise do discurso, há uma diferenciação sobre o uso da letra "d" maiúscula ou minúscula em "discurso". Esta delimitação tem como objetivo distinguir o discurso com "d" minúsculo como instância de uso da linguagem, sendo a prática de linguagem que se produz em uma situação social específica, e o Discurso com " $D$ " maiúsculo como o que circula nos contextos macrodiscursivos (GEE, 2000).

${ }^{2}$ Apresento aqui alguns artigos sobre cotas nas universidades: ARAUJO, 2019; CAVALCANTI et al., 2019; GUERRINI et al., 2018; LEMOS, 2017; MARQUES, 2018; MOEHLECKE, 2004; PAULA, 2017; QUEIROZ et al., 2015; TREVISOL; NIEROTKA, 2016.

${ }_{3}^{3}$ Apesar da origem do termo vir de estudos críticos da área jurídica sobre a subformação de advogados para fins políiticos, utilizo aqui o termo ressignificado por mim, em alinhamento ao senso comum sobre tradição de educação formal no Brasil, redefinindo-o sob o viés do poder da formação superior em uma sociedade segregada, como a brasileira. Para entender a origem do termo, sugiro a leitura de Medina (2009) e de Holanda (1995).
} 
formação omnilateral ${ }^{4}$ do aluno na educação básica. A cultura da função propedêutica do ciclo básico, valorizada apenas como um caminho à universidade, afasta os objetivos de formação integral da escola. Essa cultura torna a vaga à universidade pública um bem necessário ao prosseguimento dos ciclos acadêmicos, cuja disputa pertence a determinado segmento da sociedade.

A força propedêutica que a formação básica apresenta faz com que não haja reflexões sobre as cotas, então, para o ensino básico. Ainda. O que trago através desta pesquisa é a possibilidade de pensar a formação humana que, segundo a Lei de Diretrizes e Bases da Educação (LDB) (BRASIL, 1996), é obrigação do Estado e direito de todos. Os estudos que encontramos sobre cotas, em sua maioria, relacionam o discurso meritocrático ao desempenho acadêmico dos alunos "cotistas" , de forma quantitativa e especificamente em universidades. Senti a necessidade, no entanto, de entender de que modo esses discursos constroem os estigmas sobre os alunos nas narrativas sobre cotas.

Para entender as construções discursivas sobre o estigma dos alunos que acessam as instituições pela política de cotas, esta pesquisa adentra uma das maiores e mais antigas (cem anos de existência) instituições federais de ensino do Brasil, o Centro Federal de Educação Tecnológica Celso Suckow da Fonseca - CEFET/RJ. Proponho, com este estudo, o olhar sobre as cotas no Ensino Médio sob uma concepção êmica ${ }^{6}$, ou seja, a partir dos próprios membros da comunidade do CEFET/RJ, oferecendo possibilidades de reflexões acerca dos estigmas (GOFFMAN, 1988) imputados aos alunos.

Quando falamos em escolas de referência, como as federais, a realidade separatista vigora, tal como nas universidades públicas do país. As provas de acesso são difíceis e as relações candidato $x$ vaga são exorbitantes ${ }^{7}$ (no caso do CEFET/RJ: Informática, turno manhã - 52,41, e Administração, turno tarde $47,22)$, afastando a participação de alunos oriundos de escolas municipais e atraindo a atenção de alunos de escolas particulares renomadas e de cursos preparatórios.

\footnotetext{
${ }^{4}$ Formação multilateral ou integral, que ultrapassa a prática meramente aplicada, trazendo o conceito de pensar sobre o fazer e sobre a sua concepção. Caminha junto ao princípio da politecnia, cujo projeto se baseia tanto no rompimento com a formação profissional puramente aplicada quanto na quebra da formação propedêutica destacada do mundo do trabalho (SAVIANI, 1989).

${ }^{5}$ Cabe pontuar que, nesta tese, o termo "cotista" será utilizado entre aspas ao longo de todo o trabalho, exatamente para ressaltar e lembrar ao leitor que é o principal estigma que o aluno carrega. ${ }^{6}$ Segundo Biar (2015) a perspectiva êmica de pesquisa é aquela em que "os próprios participantes do encontro têm e demonstram sobre suas ações" em uma situação social.

${ }^{7}$ Esses dados foram solicitados pessoalmente por mim à Divisão de Concursos do CEFET/RJ, que me enviou as planilhas com os dados que não estão publicizados. A relação candidato $x$ vaga depende do curso e do turno. Expus aqui as maiores relações de 2017, para melhor ilustrar a concorrência pela qual os alunos passam.
} 
A Lei de Cotas, em si, não especifica detalhadamente como deve ser realizada a divisão dos $50 \%$ das vagas que manda reservar, deixando que a autonomia de cada instituição federal decida sobre a melhor forma de aplicação da cota. Segundo a letra da Lei:

Art. 4ำ As instituições federais de ensino técnico de nível médio reservarão, em cada concurso seletivo para ingresso em cada curso, por turno, no mínimo 50\% (cinquenta por cento) de suas vagas para estudantes que cursaram integralmente o ensino fundamental em escolas públicas.

Parágrafo único. No preenchimento das vagas de que trata o caput deste artigo, $50 \%$ (cinquenta por cento) deverão ser reservados aos estudantes oriundos de famílias com renda igual ou inferior a 1,5 salário-mínimo (um salário-mínimo e meio) per capita.

Art. 5ํㅡㄹ cada instituição federal de ensino técnico de nível médio, as vagas de que trata 0 art. $4^{\circ}$ desta Lei serão preenchidas, por curso e turno, por autodeclarados pretos, pardos e indígenas, em proporção no mínimo igual à de pretos, pardos e indígenas na população da unidade da Federação onde está instalada a instituição, segundo o último censo do Instituto Brasileiro de Geografia e Estatística (IBGE).

Parágrafo único. No caso de não preenchimento das vagas segundo os critérios estabelecidos no caput deste artigo, aquelas remanescentes deverão ser preenchidas por estudantes que tenham cursado integralmente o ensino fundamental em escola pública (BRASIL, 2012).

Desta forma, no Brasil, o principal item exposto pela lei a ser atendido é o de que os $50 \%$ reservados têm que ser preenchidos por alunos que tenham cursado o ensino fundamental inteiramente em escolas públicas. Desses $50 \%$, metade precisa ser distribuída para famílias de renda de até 1,5 salário mínimo. A distribuição para atender aos grupos de negros, pardos e indígenas, apesar de livre, deve ser proporcional e equilibrada entre si. No CEFET/RJ, por sua vez, o entendimento da lei pelo setor responsável, junto ao departamento jurídico, sobre essa divisão e distribuição, ocorre conforme o Esquema 1 a seguir: 
Esquema 1: Distribuição de cotas no CEFET/RJ, conforme regimento da Lei no 12.711/2012 (BRASIL, 2012).

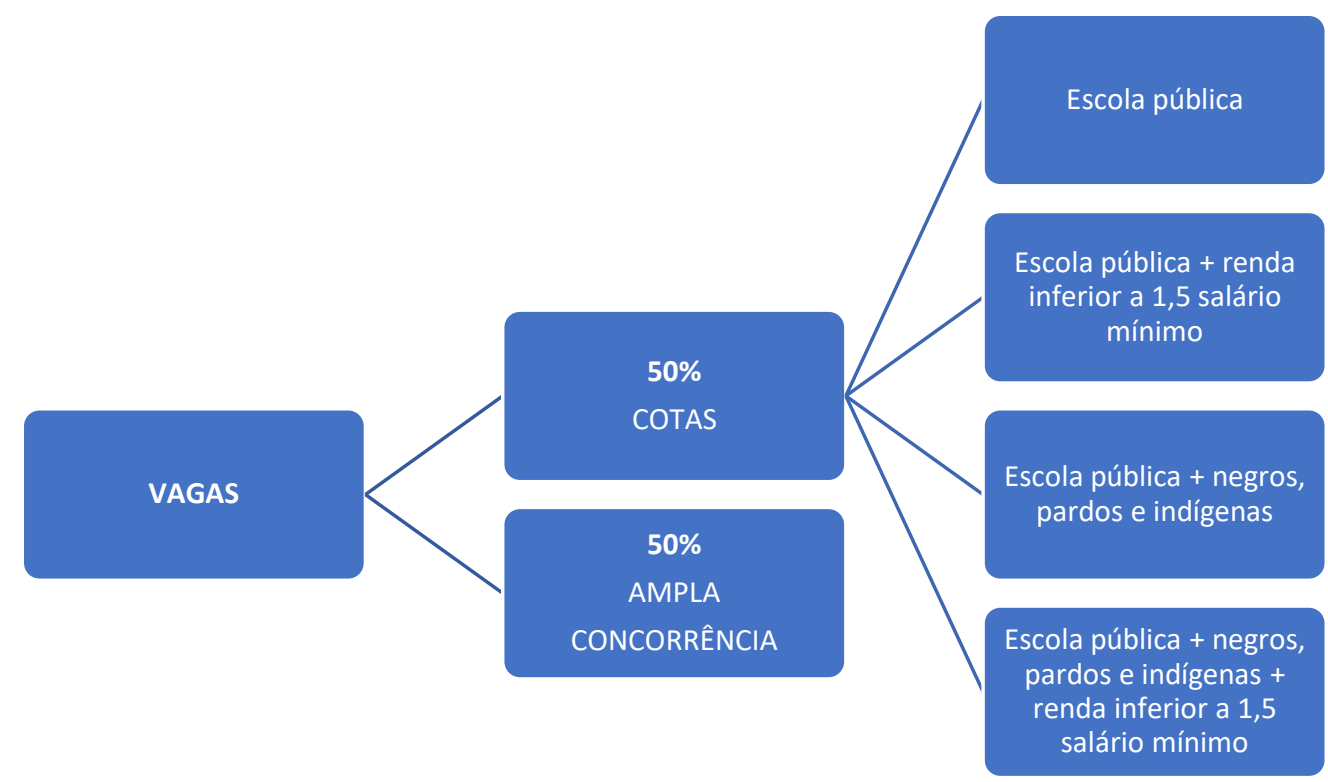

Fonte: Elaborado pela autora a partir do edital de acesso de alunos novos de 2019.

Não apenas acreditando, mas apostando na pesquisa crítica e posicionada, deixo explícito meu posicionamento nesse processo metodológico, tendo em vista o contexto no qual esta pesquisa se insere e a minha atuação no universo do trabalho. O local estudado não é apenas campo de pesquisa etnográfica, no qual estou inserida etnograficamente para gerar dados de pesquisa. Sou constituinte deste campo e atuo ativamente sobre a pesquisa, como pesquisadora, e sobre o cotidiano escolar, na função de componente da equipe de coordenação pedagógica.

O objetivo principal deste trabalho, então, é analisar, nas construções discursivas da comunidade do CEFET/RJ que recebeu em 2013 a política de cotas, como os estigmas sobre cotas e sobre os "cotistas" são criados, negociados ou desafiados pelos integrantes da instituição. No recorte proposto para esta tese, analiso especificamente o discurso dos docentes ${ }^{8}$ em situação de entrevista. Para dar conta da articulação entre os conceitos propostos neste estudo e o objetivo principal, esta proposta geral se desdobra em três questões de pesquisa, especificadas a seguir:

\footnotetext{
${ }^{8}$ Mais à frente, no capítulo de metodologia, explico o porquê da escolha de focar na análise das narrativas dos docentes, deixando de lado as narrativas dos alunos entrevistados.
} 
1. A partir de que recursos lexicogramaticais e discursivos as narrativas docentes constroem e negociam o estigma das cotas? Buscarei marcas de avaliação presentes nas construções discursivas, tentando identificar nos itens lexicogramaticais e paralinguísticos de avaliação as descrições sobre os alunos "cotistas".

2. A quais sistemas de coerência os docentes se afiliam? Quais são as marcas de alinhamento dos participantes com discursos (re)produzidos e ancorados em sistemas de coerência de senso comum sobre cotas? Esta questão surge para entender como as narrativas dos entrevistados se relacionam com os embates discursivos sobre a política de cotas.

3. Quais estratégias retóricas os docentes utilizam para criação, manipulação, manutenção, resistência, subversão, etc. dos sistemas de coerência sobre cotas vigentes na sociedade? Por meio da identificação das estratégias utilizadas, foi possível entender o caminho da construção discursiva dos estigmas sobre os alunos.

Com os objetivos específicos aqui propostos, a principal tarefa que este trabalho toma pra si é compreender como se constroem discursivamente os índices que formam os estigmas sobre cotas, sobretudo o próprio termo "cotista" como identificação dos alunos. É preciso entender as categorizações indexicais que identificam "alunos" e, separadamente, "cotistas" na escola, termo que se repete por todas as entrevistas. Ou seja, é necessário entender a indexicalização do termo "cotista", que é utilizado não apenas por docentes ou por pessoas que se posicionam contra cotas, mas por toda a comunidade escolar, incluindo os próprios alunos que acessam pela política de cotas e eu.

Para dar conta dos objetivos que aqui proponho, incluindo os últimos questionamentos mais gerais que realizei nos parágrafos anteriores, esta tese apresentará a seguinte distribuição textual:

No capítulo 2, apresento o contexto do CEFET/RJ, sua história e construções identitárias mais amplas ao longo de seus cem anos de existência e remodelações. Nesse capítulo, explico também a minha posição dentro dessa instituição e os modos como eu me divido, ou me misturo, enquanto pesquisadora e servidora. Também apresento alguns detalhes específicos sobre as organizações administrativa e pedagógica internas. 
No capítulo 3, exponho o posicionamento metodológico e o contexto de pesquisa, e lá serão apresentadas as costuras teóricas que proponho nesta tese. Esse alinhamento de teorias é o desafio que assumi para alcançar o entendimento sobre as construções discursivas, acreditando que a união de conceitualizações e procedimentos metodológicos de análise seja muito rico para as pesquisas sociais. Ainda nesse capítulo, explico o que entendo por olhar microinteracional e o lugar desta visada na pesquisa, informo sobre as nuances autoetnográficas presentes em meu estudo e me posiciono em meu local de fala. Descrevo, ainda, os procedimentos de pesquisa que mobilizo, como os modos de geração de dados, as metodologias de análise, as características das entrevistas e das transcrições, os recortes analíticos que faço, a descrição dos participantes e as questões éticas que envolvem a minha pesquisa de doutorado.

No capítulo 4, faço uma revisão teórica sobre o arcabouço de teorias que utilizarei para dar suporte às análises que proponho. A essa altura da tese, eu desenvolvo a ideia de que as narrativas são (re)construções pessoais e sociais do sujeito (LABOV,1972) e adentro o conceito de sistema de coerência (LINDE, 1993). Então, desenvolvo a discussão de Littler (2018) sobre meritocracia, relacionando-a com autores do discurso (FOUCAULT, 1972; BAKHTIN, 2003; GOFFMAN, 1986). Após isso, trago Goffman (1988) para apresentar o conceito de Estigma e mostro de que forma esse conceito é transportado para o meu contexto de pesquisa e utilizado como o resultado da indexicalização do discurso sobre cotas no Brasil. Ainda nesse capítulo, sigo para a explicação das teorias que embasam os procedimentos analíticos dos dados e dou enfoque à proposta e análise de movimentos retóricos organizada por Wodak et al. (2009) e ao sistema de avaliatividade (MARTIN; WHITE, 2005; NÓBREGA, 2009; WHITE, 2004).

No capítulo 5, inicio o processo de análise de 43 excertos de narrativas dos docentes entrevistados para esta pesquisa. O capítulo é dividido em narrativas que foram analisadas de acordo com a lente de análise das estratégias retóricas propostas por Wodak et al. (2009) e sua relação com a construção dos estigmas sobre cotas e sobre os alunos "cotistas". As subseções são organizadas da seguinte maneira: (i) narrativas de transferência de culpa ou responsabilidade, (ii) narrativas de trivialização das discriminações, (iii) narrativas de engajamento docente, (iv) narrativas de conservação do velho modelo, (v) narrativas de descrédito dos alunos e da política de cotas e (vi) narrativas de descontinuação da política de cotas. 
Por fim, no capítulo 6, apresento as considerações finais desta tese, nas quais estão a costura final de todas as discussões e conclusões a que cheguei. Neste ponto, poderá ser verificado que os objetivos que propus neste estudo foram cumpridos. 
unidade Maracanã estão as diretorias ${ }^{9}$ que também são sistêmicas, planejando, definindo, acompanhando e avaliando as atividades dos campi. Em todos os campi são oferecidos cursos técnicos de nível médio, além de outros níveis de ensino até o doutorado, como na unidade Maracanã.

A estrutura curricular dos antigos Ensino Médio e Ensino Técnico do CEFET/RJ também passou por modificações no percurso das alterações pedagógicas e estruturais. A última mudança ocorreu com a efetivação da nova modalidade de ensino (modalidade integrada) com o edital de 2012 para a entrada de alunos novos em 2013. De 1998 até 2012, o regime existente na instituição era o de concomitância interna, que compreendia duas matrículas para cada aluno, sendo uma para cada turno com segmento médio separado do técnico. Isso significava a existência de dois currículos separados para a formação básica e para a formação técnica. Com este modelo, o índice de evasão tornava-se alto, em especial nos cursos técnicos, chegando a mais de $90 \%$ em alguns cursos ${ }^{10}$.

Com a mudança de gestão do departamento de ensino médio e técnico, esses dados começaram a ser trabalhados para iniciar uma gestão que relacionasse os processos pedagógicos e acadêmicos com os índices de aprovação e evasão. Por meio dessas análises, foi possível entender que o modelo que vigorava não atendida ao índice mínimo de evasão recomendado pelo Ministério da Educação (MEC).

Concomitantemente aos estudos da nova gestão, grupos de estudos foram formados com equipes pedagógicas e docentes interessados em discutir processos didático-pedagógicos pertinentes à realidade da instituição. Desses grupos participavam também os gestores do departamento junto às equipes que se alinhavam sobre as concepções de politecnia (FRIGOTTO, 1985). Para fins de localização contextual, a politecnia objetiva oportunizar uma formação omnilateral, que assegura a criticidade do processo do fazer, adjacente à formação técnica, com base no trabalho como princípio educativo.

Os $371^{11}$ docentes do CEFET/RJ Maracanã dividem-se entre o ensino profissional técnico de nível médio (modalidade Integrado ${ }^{12}$ e modalidade subsequente), graduações, mestrados e doutorados. Destes, 116 têm a titulação

\footnotetext{
9 Diretoria de Ensino, Diretoria de Pós-Graduação, Diretoria de Extensão, Diretoria de Gestão Estratégica, Diretoria de Extensão, Diretoria de Administração e Planejamento.

10 Dados dos arquivos de estudos internos do departamento.

${ }^{11}$ Dados públicos de prestação de contas retirados em 2017 do site do CEFET/RJ (www.cefet-rj.br).

12 Modalidade Integrada é a modalidade definida pelo MEC para os cursos de Nível Médio integrados curricularmente ao Ensino Técnico, característicos de instituições de formação técnica como CEFETs e IFFs. Já a Modalidade Subsequente é o curso de Nível técnico para pessoas que já possuem a formação de Nível Médio ou que estão em vias de terminá-la em outra instituição que não o CEFET/RJ.
} 
de doutorado e 163 têm a titulação de mestrado. A estrutura física utilizada pelo departamento de ensino médio e técnico, responsável pelos 11 cursos profissionais técnicos de nível médio e subsequentes, corresponde a 34 salas distribuídas em diversos blocos. Essas salas atendem às 64 turmas divididas entre os turnos da manhã e da tarde e mais um número de turmas no turno da noite, este último somente para a modalidade subsequente, a qual não foi abordada neste estudo devido à delimitação de escopo de pesquisa.

Cabe expor, a partir do cenário descrito nesta subseção, a minha relação com a instituição. Ocupo cargos de gestão desde a minha entrada no CEFET/RJ, que se deu em 2009, tendo passado os primeiros quatro anos chefiando a divisão de apoio pedagógico, na qual estão lotados os orientadores educacionais, cujo trabalho acontece na interação com os alunos para acompanhamento acadêmico deles junto aos docentes. Portanto, nos cinco primeiros anos de instituição, os laços criados com os docentes foram se estreitando para que o trabalho com os alunos fluísse da melhor forma possível. Com a minha mudança de setor para o departamento, hierarquicamente acima da primeira divisão, em um ano fui convidada a assumir o cargo de coordenadora pedagógica do departamento, o qual ocupei até julho de 2018, quando me licenciei por um ano e sete meses para o desenvolvimento desta pesquisa.

Com o cargo, a minha atuação passou a se dar diretamente com os coordenadores (de disciplina e área) dos docentes e, devido à natureza do trabalho de coordenação pedagógica, todas as situações referentes a problemas, reflexões e articulações pedagógicas foram e são realizadas por mim junto aos docentes. Cabe uma breve explicação da característica do trabalho de coordenação pedagógica a que o departamento se alinha, a fim de compreender as relações entre mim e os docentes para este estudo.

Vale explicar, também, que me coloco e me posiciono neste momento como "departamento" por ter criado o cargo que ocupei através de um projeto de reorganização pedagógica, solicitado a mim pelo Departamento, quando ainda estava na chefia da Divisão de Apoio Pedagógico. Sendo assim, eu fui a autora inicial das atribuições, concepções e o modus operandi do cargo de coordenador pedagógico, que antes não existia no CEFET/RJ, unidade Maracanã. Desta forma, entrego a mim mesma o poder de descrever como a equipe de coordenação pedagógica do Departamento operou a partir de sua criação até meados de 2018, quando saí do cargo.

O trabalho de Coordenação Pedagógica que realizo no Departamento vai além da dimensão hierárquica de pedagogia de "supervisão", definida 
historicamente na educação. Acredito na atuação dialógica, que é realizada em parceria com as coordenações de disciplina, de curso e com os profissionais da orientação educacional de alunos. Neste sentido, entendo que os espaços de diálogo têm extrema importância para essa transformação. Com isso, sustento a proposta de proporcionar espaços de trocas de experiências e discussões diante das situações que os docentes vivem diariamente. O trabalho da coordenação pedagógica é proporcionar reflexões de construção, desconstrução e reconstrução das ações pedagógicas, através da articulação em grupo entre todos esses agentes escolares.

A equipe de coordenação pedagógica construiu, até o ponto em que eu estive como coordenadora, novos projetos de articulação com os docentes, de modo a proporcionar trocas de experiências acerca de metodologias de ensino e avaliação entre seus pares, que estão em sala de aula, e que muito sabem sobre o que realizam. Por fim, a coordenação pedagógica do departamento não só não se alinha, como marca posição crítica ao que a tradicional coordenação e supervisão pedagógica realiza e acredito que, além de afastar pessoas e criar embates, impõe métodos fixos de ensino e avaliação de modo a padronizar tanto os docentes quanto os discentes.

Para completar o entendimento das relações que tenho com o corpo docente e equipe pedagógica, a estrutura é mais bem explicada através do próprio organograma do CEFET/RJ:

Organograma 1: Organização hierárquica do Departamento de Ensino Médio e Técnico.

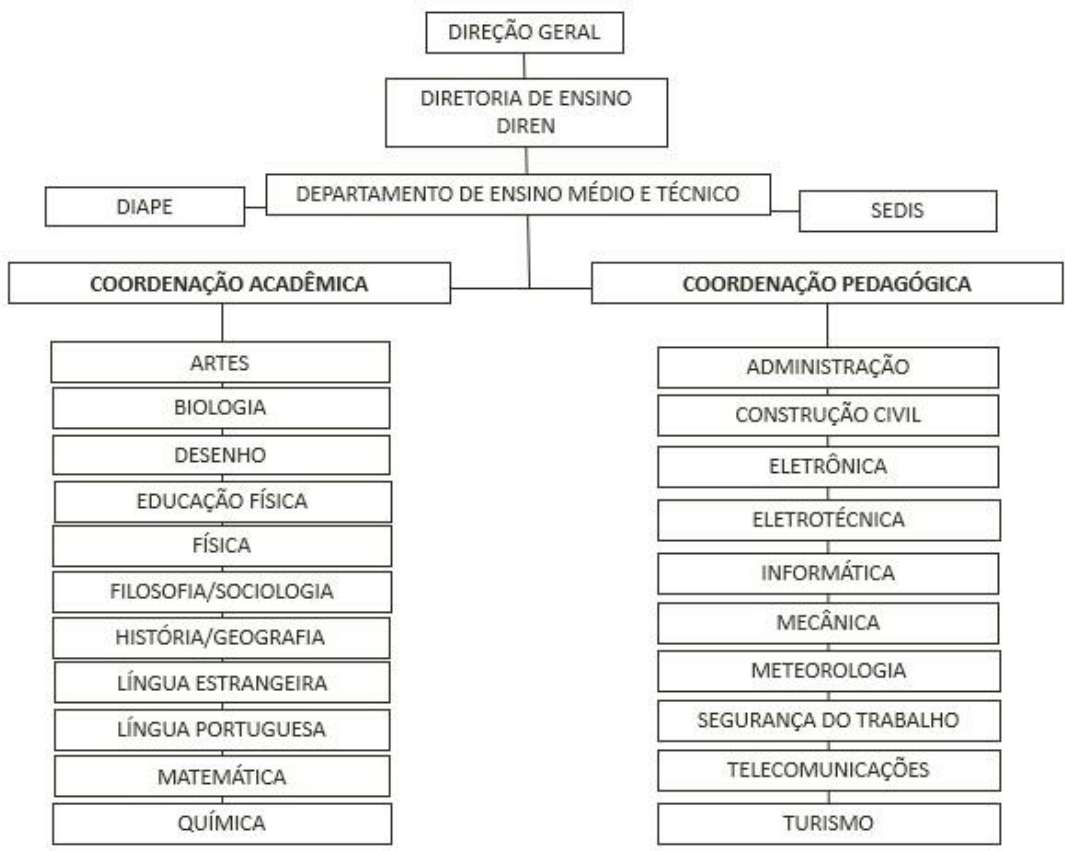

Fonte: Projeto Pedagógico de Curso. Documento publicizado no site do CEFET/RJ. 
Esse organograma mostra não só a organização hierárquica ou física das coordenações, mas também como funciona a estrutura ampla de representatividade dos colegiados quando ocorrem mudanças, como a reforma curricular. E a reforma aconteceu na mesma época em que o sistema de cotas foi implementado. Para que as mudanças acontecessem, os professores se reuniram em diversas comissões ao longo de 2011 e 2012, guiadas pelo departamento.

A partir da delimitação da nova estrutura curricular, o edital ${ }^{13}$ para acesso de novos alunos foi elaborado e publicado. Alguns docentes questionaram a adequação do edital à Lei no 12.711/2012, Lei de Cotas (BRASIL, 2012) e, então, o setor responsável pelo concurso realizou uma consulta pública ao MEC, que respondeu que deveria ser aplicada a Lei de Cotas (BRASIL, 2012) e, por isso, o setor de concursos retirou o edital publicado para adaptação à legislação, republicando-o, posteriormente, para a continuação das inscrições. Dado o tempo exíguo entre o edital, o processo seletivo e o início das aulas, a instituição não teve tempo hábil para ajustar as organizações pedagógicas internas para recepção dos alunos "cotistas".

Rapidamente, espalhou-se a notícia de que a metade dos alunos que o CEFET/RJ receberia naquele ano era de cotas, pelos mais variados meios entre a comunidade escolar, não só nos encontros pessoais, mas, também, em discussões virtuais pela página do facebook, criada e administrada por alunos. Até o ano de 2012, os alunos matriculados no regime de concomitância interna eram, quase que em sua totalidade, oriundos de escolas particulares, configurando um público de discente majoritariamente branco e de renda familiar média/alta. Com a mudança, foram criadas expectativas de atributos diferenciados dos normativos da instituição, não só no que se refere ao padrão racial da escola, mas ao medo de "queda" da qualidade de ensino, muitas vezes repetido.

O discurso de receio na imagem projetada de excelência percorreu todos os espaços escolares formais e informais. O título desta tese, inclusive, remete a uma frase dita em um conselho de classe por uma docente, ao se pronunciar sobre a entrada "destes" alunos no CEFET/RJ, e foi completada com a afirmação de que ela não estava acostumada com "este tipo de aluno, sujo, fedorento e com roupas

\footnotetext{
13 Para estudar no CEFET/RJ, é necessário realizar concurso público em forma de vestibular. O edital de seleção é elaborado e revisado pelos setores de concurso e pedagógico e publicado no site do CEFET/RJ; os candidatos se inscrevem e realizam a prova para eliminação em primeira instância (disciplinas gerais) e classificação em segunda instância (língua portuguesa e matemática).
} 
largadas". Esta tese toma para si exatamente a tarefa de criar entendimentos sobre discursos como esse.

A implementação da política de cotas no CEFET/RJ, portanto, foi um tanto quanto confusa por diversos motivos e, em especial, pelo despreparo de toda a comunidade escolar diante da exigência de seu início no edital de 2012. Alunos, ex-alunos e docentes já começaram a externalizar, via redes sociais, préconceituações e antecipações do quão ruim seria a entrada de alunos pela reserva de vagas pela política de cotas. Em resumo, a implementação da política foi uma questão relevante na época. As falas oriundas de postagens, que retirei da rede social facebook que exponho aqui, podem ilustrar melhor como isso aconteceu.

No grupo aberto de alunos do CEFET/RJ (no qual docentes e demais profissionais também estão inseridos), um aluno questiona, em 2012, frente à mudança de política de acesso à escola, como funcionaria a nova entrada de alunos através das cotas e, logo a seguir, seguem as respostas que considero mais expressivas para essa contextualização:

(Aluno 1 realiza a pergunta - 8 de agosto de 2012)

"Relativo a cota que obriga as universidades públicas e escolas técnicas de nível superior permitirem a entrada de $50 \%$ do total de vagas para alunos de escolas públicas. Essa conta será para alunos de escolas: estaduais, federais e militares?"

(Professora 1 - Ensino Médio)

"O Colégio Militar tem cotas para filhos de militares, E MUUUUUITAS!!! O concurso público para os filhos de civis oferta um número muito reduzido de vagas e nunca vejo as pessoas protestarem contra isso. Instituições militares como Colégio Naval, EpCar etc estão vinculadas ao Ministério da Defesa, não ao MEC (tanto que, lá, falar de greve é praticamente um sacrilégio rs!). Quanto ao uso de ações afirmativas (como é o caso das cotas raciais e/ou sociais), sugiro leitura aprofundada e um olhar histórico para o problema da exclusão de negros e pobres das escolas e universidades no Brasil. No CEFET/RJ, inclusive, há pesquisadores que estudam a temática a fundo no Mestrado em Relações Etnicorraciais, pioneiro no país e referência para várias outras instituições. Aquela casinha vermelha que fica perto do pátio é o NEAB (Núcleo de Estudos Afro-Brasileiros) e, em vários horários ao longo do dia, vocês podem conversar com os alunos do Mestrado (muitos deles COTISTAS, e nem por isso menos capazes, como o senso comum insiste em rotulá-los). Vale a pena pesquisar a fundo a temática."

(Professor 2 - Ensino Médio)

"Nenhum sistema de cotas, seja ele aplicado em qualquer lugar do mundo, em relação a seja qual for o segmento (mulheres na política, necessidades especiais, idosos, classe social) é uma forma fácil. Ao contrário, é uma forma política de luta de combate às desigualdades. Há um princípio aristotélico que diz o seguinte: 'A verdadeira igualdade consiste em tratar-se igualmente os iguais e desigualmente os desiguais a medida em que se desigualem'. Só é possível entendermos a necessidade do sistema de cotas raciais no Brasil, se estudarmos a história do privilégio histórico dos brancos, os projetos de embranquecimento desta nação, a história da eugenia e a história da tentativa de genocídio das populações negras que aqui chegaram por sequestro e têm sido desumanamente exploradas há séculos. A reação que surge às cotas vem de um segmento da sociedade que tem gozado de muitos privilégios, dos quais não quer abrir 
mão, em nome de uma falsa meritocracia. Hoje, há muitas pesquisas científicas de qualidade, produzidas pelos pesquisaodres $(\mathrm{sic})$ e pelos órgãos mais sérios e mais comprometidos do país que provam que a única maneira de nos aproximarmos de alguma equidade e de alguma democracia no Brasil a médio prazo é pelas ações afirmativas. Deixo-Ihes alguns documentos e pesquisas oficiais para leitura, para que essa discussão seja embasada teoricamente, não em achismos, que não nos levam a lugar algum."

(Professora 1 - Ensino Médio)

"Investir em Educação Básica é fundamental, sem dúvida, e, em nenhum momento, as ações afirmativas excluem essa necessidade (até porque comprometeria todo processo de formação de uma elite intelectual oriunda de grupos sociais desprivilegiados historicamente, como é o caso de negros e pobres). A questão é que, se só for investido na base, esperaremos mais 30, 40,50 anos para termos o resultado efetivo disso. A situação é tão grave, tão crítica, que não temos mais tempo a perder. Fadar o aluno negro/pobre ao fracasso na universidade porque ele não tem base é muito cruel e, ao mesmo tempo, exime o Estado de suas próprias responsabilidades. Falar de falta de base é muito relativo. Se pensarmos a realidade do CEFET/RJ, por exemplo, tenho muitos alunos que entram sem base, e olha que fizeram cursinho preparatório, estudaram em escola supostamente de ponta etc. Se o cara tiver dificuldade na faculdade, tendo feito o vestibular tradicional, a culpa é exclusiva do aluno (porque ele não estudou, não quis nada e aquelas coisas todas que escutamos sempre); agora, se o cara é cotista e ficar reprovada, quem tem culpa é a pobreza dele e a falta de base? É essa a lógica? O @@@ ${ }^{14}$ colocou aí o resultado da primeira turma de Medicina da UERJ com cotistas: médicos e residentes negros, de origem pobre, só para contrariar o discurso de que não daria certo por ser uma política 'eleitoreira'."

(Aluno 2, que logo após esta resposta postou um vídeo intitulado "cotas e o afrocoitadismo")

"Dizer que favela é a nova senzala é um retrocesso absurdo. A sociedade é mil vezes mais complexa do que isso. Reparação histórica, p'ra mim, é um argumento completamente inválido, Cota RACIAL não deveria estar em discussão. O que deveria estar em discussão é a qualidade da educação pública. Num país altamente miscigenado, eu pergunto aqui: quem é negro e quem é branco? Eu sou negro? Eu tenho direito à cota na universidade? Eu tenho conhecimento de dois tataravôs meus, que eram negros, de pele bem escura. Então eu sou afrodescendente? Pela lógica, sim. Se alguém disser que eu não sou, e não tenho direito à cota, então nós vivemos uma verdadeira loteria. Aliás, eu não sou afrodescendente, eu sou brasileiro!."

(Aluno 3)

"Eu nem vejo como problema os pobres entrarem no Ensino Superior, o problema é eles ocuparem vaga e não concluírem o curso ou abandonarem! Como disse o@@@@, tem-se que oferecer meios do aluno se manter no curso."

Esses são apenas alguns comentários que separei para mostrar os rumores que já se formavam antes dos primeiros alunos serem matriculados no CEFET/RJ pela política de cotas. Como se pode perceber, já havia uma série de opiniões sobre as cotas e expectativas de diversas situações que hoje formam os estigmas sobre os alunos. Mas, principalmente, é importante observar que o principal índice criado para o aluno, o termo "cotista", já era evidenciado até mesmo nas falas dos docentes que defenderam a política de cotas. É interessante notar esse aspecto

\footnotetext{
${ }^{14}$ Os nomes citados foram trocados por “@@@”, para a proteção das identidades.
} 
em que trabalharei no capítulo de análise, pois o termo é uma determinação de que seu processo seletivo de acesso pelas cotas se tornaria sua identidade ao longo de toda a sua trajetória acadêmica dentro da escola.

Essas opiniões, junto a mais outras diversas que circulavam nesse período pelos espaços virtuais, reverberaram após a entrada dos alunos no CEFET/RJ. Estando na coordenação pedagógica, posso contar que as reuniões em geral e de conselhos de classe giravam em torno do problema que estávamos enfrentando a partir de 2013, que era o de desempenho ruim dos alunos. Mesmo sabendo que a mudança curricular veio concomitante à implementação da política de cotas, nunca foi colocada em xeque a possibilidade de haver a necessidade de reajustes nos currículos novos. A culpa dos maus desempenhos seria sempre dos, então, "cotistas".

Até então não havia nenhum levantamento sobre o desempenho dos alunos para entender se o problema havia sido realmente dos alunos "cotistas" novos ou de todos os alunos em geral por todas as mudanças oriundas na reformulação da modalidade de ensino, que incluíram, inclusive, horários completamente diferentes dos existentes. Esses levantamentos estatísticos foram realizados a partir de 2014, pela chefia do departamento de ensino médio e técnico. Quando foi realizado o levantamento, havia, sim, uma tendência dos alunos "cotistas" ao desempenho acadêmico abaixo da média 6,0.

Porém, conforme pode ser encontrado em um estudo realizado por mim e pela chefia do departamento e publicado nos anais do I Encontro Integrado de Educação Profissional Intercampi do CEFET/RJ (PEDROTTI; TEIXEIRA, 2017), após a implementação de políticas de permanência, o quadro muda drasticamente. O estudo que publicamos engloba todos os alunos que obtiveram desempenho baixo, entre 2015 e 2017, sem delimitação de quem é "cotista" ou não. Isso indicou, à época, que qualquer problemática que envolvesse falta de base não deveria ser direcionada a alunos de cotas ou não, mas à falta de política de permanência que fossem eficientes na escola para todos os alunos. Não importa, ou não deveria importar enquanto departamento, se o aluno que está com média abaixo de seis marcou a caixinha de "cotas" ao preencher o formulário de inscrição para o certame público.

Mas, como eu disse anteriormente, em todas as reuniões realizadas entre docentes e equipes pedagógicas, a culpabilização aos "cotistas" estava sempre em voga. Após a implementação da política de cotas, todo e qualquer grupo de alunos em uma turma que estivesse com baixo rendimento eram imediatamente identificados como "cotistas", sem mesmo haver a certeza se haviam acessado 
pela política. Vale ressaltar que somente o departamento tem essas informações e, mesmo após o levantamento estatístico desses dados de desempenho acadêmico pela chefia, eles não foram publicizados ${ }^{15}$ exatamente pela delicadeza sobre as informações oriundas das estatísticas.

Percebo que essa é uma questão que se iniciou antes mesmo da implementação da política de cotas. Foi reforçada nos primeiros anos e levemente diluída ao completar o primeiro ciclo de formação dos alunos que entraram em 2013. Porém, é ainda uma questão forte e que paira nas reuniões de colegiados, pedagógicas e conselhos de classe, em especial, nas disciplinas que demandam fundamentos básicos do ensino fundamental. E é por esse motivo, a onipresença dos estigmas sobre as cotas, que tomei por hábito fazer as anotações durante essas reuniões.

No início das minhas observações, para entender qual era o caminho que precisava dar ao meu tema de pesquisa, comecei algumas dessas anotações durante as reuniões institucionais e após algumas entrevistas. A nota que abre este capítulo fez parte do meu diário de bordo após uma entrevista bastante tensa para mim e, suponho, para o aluno também. Havíamos vivido uma situação extrema de embate, eu, enquanto representante do Departamento de Ensino Médio e Técnico (e vista pelos alunos como representante da Direção Geral), e o aluno presente nessa entrevista específica.

Uma aluna havia postado nas redes sociais opiniões bastante ofensivas e evidentemente racistas, e o coletivo negro Azoilda Loretto do CEFET/RJ se mobilizou rapidamente para que a situação tivesse uma resposta. Porém, essa mobilização foi tão rápida que aconteceu antes mesmo da situação ter chegado oficialmente ao Departamento para ações e sanções cabíveis. Por isso, o coletivo negro Azoilda Loretto do CEFET/RJ e os alunos passaram à frente da situação para resolver o episódio de racismo do modo que eles acharam justo. Colaram cartazes pela escola em resposta e já haviam planejado ações pontuais diretamente com a aluna responsável pela postagem.

Resumindo essa história, tudo culminou na fatídica reunião de que participei junto a mais outros dois profissionais representando o departamento. Tudo que foi dito pelo departamento, incluindo minhas falas indicando a solução mediada pela legislação, foi interpretado negativamente pelos demais integrantes da sala e ao sabor da dor que os alunos estavam sentindo com a situação. Nessa reunião

\footnotetext{
${ }^{15} \mathrm{~A}$ decisão pela não publicação dos dados estatísticos sobre a relação entre desempenho escolar e modo de acesso ao CEFET/RJ foi tomada pela chefia do departamento junto à equipe pedagógica para preservação dos alunos, suas identidades, e evitar que quaisquer estigmas fossem criados ou reforçados a partir dos resultados.
} 
também estava o aluno que cerca de um ano depois eu chamei para a entrevista da minha pesquisa de doutorado. As notas de campo mostram o quanto essa entrevista foi recheada de medos, dores, assimetrias e explicações demasiadas de ambos os lados, criando uma interação extremamente tensa.

Trago essa história para ilustrar a importância das emoções que perpassam a interação em minhas entrevistas de pesquisa. Esse é apenas um dos exemplos das tensões que experimentei e, provavelmente, os participantes também experimentaram, nas entrevistas para a pesquisa que origina agora a minha tese. Não é um campo fácil de adentrar tematicamente. Os elementos interacionais oriundos da minha dupla atuação (pesquisadora/coordenadora) também trouxeram densidade a tudo que foi conversado, gerado, discutido e analisado em meus dados.

O escopo da pesquisa foi desenhado, então, a partir da minha perspectiva empírica, quando percebi, em meu campo de trabalho, certas construções dialógicas sobre o aluno "cotista". Nas discussões no CEFET/RJ sobre cotas, identifiquei expectativas e estereótipos que julguei como problemáticos em relação aos alunos. Como ocupava o cargo de coordenadora pedagógica na instituição, a pesquisa acabou por apresentar esse viés (auto)etnográfico.

Por fim, desde a implantação da política de cotas, o CEFET/RJ, representado por todos os componentes que atuam sobre a trajetória acadêmica dos alunos (coordenação pedagógica, professores, equipes multiprofissionais de apoio), vem lutando pela manutenção dos alunos na escola. A grande problemática é a que envolve a permanência e diminuição da evasão, seja por reprovação, seja por desistência. Como a política de cotas foi implementada junto à mudança curricular, os olhos e mãos de todos esses componentes estavam voltados somente para a nova estrutura curricular, não havendo reuniões prévias para orientação sobre a permanência dos alunos de cotas.

Por esse motivo, não somente os estudos estatísticos sobre dados de evasão, reprovação e desempenho acadêmico apenas foram iniciados nos anos seguintes à entrada dos alunos "cotistas", como também os programas mais sólidos de permanência só foram pensados a partir de 2015. Isto é, até 2015 não havia programas de recuperação de conteúdos direcionados aos alunos com médias bimestrais abaixo de 6,0 (média para aprovação), além das monitorias. Apenas após a percepção de que os alunos estavam indo mal, foram iniciados os planejamentos sobre ações de permanência para eles, como os programas de matemática básica, química zero e ampliação de monitorias já existentes. 
Sendo assim, o que ficava no ar eram sensações empíricas de que a "culpa" pela queda brusca de desempenho geral era dos "cotistas", não havendo dados estatísticos, até então, que comprovassem o contrário. O senso comum de que a entrada dos alunos por cotas trouxe a queda da qualidade de aprendizagem prevaleceu, criando bases para histórias em comum de insucesso da política de cotas. Hoje, já existem dados que indicam que a maior evasão no CEFET/RJ ocorre no primeiro ano, por alunos que desistem da escola logo no primeiro bimestre, o que o departamento chama de "evasão zero". Os motivos variam desde a escolha por outros colégios, para os quais os alunos também obtiveram aprovação, ou desistências por motivos múltiplos, não relacionados ao CEFET/RJ em si.

Mas tenho a sensação, após ouvir tantas histórias em reuniões, conselhos de classe e nas entrevistas da minha pesquisa, que as narrativas são demonstração de que o pensamento de "culpa" pela degradação da escola aponta sempre ao aluno "cotista". Após esses anos da implantação da política de cotas, mesmo com todos os avanços de política de permanência e esforços múltiplos de todas as equipes e colegiados, mesmo após dados estatísticos que comprovam que a evasão maior não é a do "cotista", as histórias são sempre culpabilizando o aluno por tudo de ruim que ocorre na escola.

Esta orientação sobre a instituição é necessária para que se entendam as características identitárias que originam o CEFET/RJ e guiam a manutenção de elementos pontuais sobre o constructo do ideal do mérito. É preciso entender as bases de formação ideológicas e, consequentemente, discursivas da instituição para visualizar as expectativas que se apresentam sobre os alunos. Agora, após o entendimento sobre o que é o CEFET/RJ, no próximo capítulo exponho o posicionamento metodológico da pesquisa de tese e seu contexto. Nesse capítulo, então, são apresentados a caracterização dos dados, o contexto da pesquisa, a metodologia utilizada e as questões éticas e políticas inerentes à pesquisa. 


\section{3 Posicionamento metodológico e contexto de pesquisa}

"Na minha sala tem uma garota, a Ana, ela se acha melhor por ter não ter cota e ter passado e, tipo, menospreza quem é cotista, eu, no caso, sou cotista, quando ela vem assim... só que eu não dou muita ideia pra ela não, aí ela quer vir com esses argumentos 'ah, porque ela estudou no xx (colégio particular)', que é uma escola que tem aqui perto e eu vim de escola fundamental só que se for olhar as notas, a minha nota foi melhor do que a dela então, a cota, no meu caso, não fez diferença alguma."

(Trecho da entrevista realizada com Claudio, aluno participante desta pesquisa.)

Neste capítulo, explicito o posicionamento epistemológico e metodológico da pesquisa e meu lugar de fala neste processo de doutoramento.

A pesquisa qualitativa se preocupa com fenômenos e processos sociais que permitem a percepção de aspectos que estruturam a vida social (PÁDUA, 2004, p. 36) e que constroem as representações sociais. Completando essa ideia, dialogo com Creswell (2007), que entende a pesquisa qualitativa como um meio para explorar e para entender o significado que os indivíduos ou os grupos atribuem a um problema social ou humano. Esta pesquisa trabalha com especial atenção à dimensão sociocultural "que se expressa por meio de crenças, valores opiniões, representações, formas de relação, simbologias, usos, costumes, comportamentos e práticas" (MINAYO, 2017, p. 2).

Neste viés, torna-se cada vez mais habitual nas pesquisas sociais a ideia de que os conhecimentos teóricos são "particulares, situados e contextualizados" (LOPES, 2004, p. 167-168). Partindo da conclusão de Minayo (2017, p. 3) de que "cada individualidade é manifestação do viver total", preconizo nesta pesquisa a valorização da fala particular dos participantes. Nesse sentido, trabalho com a ideia de que as narrativas dos participantes deste estudo são coconstruídas nos alinhamentos aos discursos de seus pares na escola. De certa forma, assim se apresenta o grupo do qual fazem parte, trazendo à tona aspectos culturais macros da instituição que tangenciam a singularidade dos participantes (MINAYO, 2017, p. 3).

E é pelo viés da perspectiva construcionista que encontro métodos que orientam as análises interacionais do discurso nesta pesquisa. A epistemologia construcionista, segundo Bastos e Biar (2015, p. 99), "marca boa parte da reflexão contemporânea e brasileira da Linguística Aplicada, especialmente no que diz 
respeito ao seu caráter multi e interdisciplinar e sua postura crítica e eticamente informada sobre as diferentes questões sociais que constituem seu interesse". Através dessa perspectiva, então, me posiciono de forma que possa me engajar com o tema de pesquisa com o compromisso ético de transformação das problemáticas sobre cotas no Brasil.

Por fim, por apresentar um foco multiparadigmático, Denzin e Lincoln (2006, p. 20) indicam que "a pesquisa qualitativa, como um conjunto de atividades interpretativas, não privilegia nenhuma única prática metodológica em relação à outra", sugerindo que se usem múltiplas abordagens de análises e de práticas interpretativas. Na próxima seção, abordarei três pontos basilares para este posicionamento metodológico: o olhar sobre o micro na interação, a pesquisa de cunho (auto)etnográfico e o local de fala.

\title{
3.1. \\ Por que olhar a microinteração nesta pesquisa?
}

Para iniciar o posicionamento desta pesquisa na base interacionista, esta subseção tratará de abordar o olhar sobre o "micro" dentro da interação, partindo da ideia de Miller e Glassner (1997, p. 126), segundo a qual

\begin{abstract}
a pesquisa não pode refletir o mundo social exatamente como ele é, mas pode proporcionar acesso aos significados que as pessoas atribuem às experiências vividas nestes mundos sociais. Enquanto a entrevista é, por si só, uma interação simbólica, isso não descarta a possibilidade de que o conhecimento do mundo social além da interação possa ser obtido.
\end{abstract}

Considerando que a pesquisa qualitativa possibilita o olhar sobre as práticas de linguagem que emergem dos encontros sociais e nas quais ocorrem construções identitárias (BASTOS; BIAR, 2015, p. 103), a perspectiva de colocar uma lente sobre a microinteração posiciona o discurso que dela surge como objeto de pesquisa. Entendo que as interações propostas pelas entrevistas, na fase de geração de dados desta pesquisa, são por si uma ordem interacional micro que pode representar uma ordem social macro. E é a partir dessa compreensão que busco perceber quais aspectos interacionais ajudam a responder as questões de pesquisa que propus.

Neste sentido, ao me posicionar sob o paradigma de pesquisa interpretacionista, encontro na consideração de Biar (2009, p. 6-7) a reflexão 
sobre a dimensão do trabalho de Goffman de "tornar explícitos tais elementos, com vistas a fornecer bases teóricas para que se entendam os modos como as pessoas atribuem valor simbólico ao que é dito e feito nos encontros sociais".

\section{2. \\ Explicando melhor o cunho (auto)etnográfico}

Entendo aqui que meu local na pesquisa não é isento do olhar pessoal, construído através da imersão no campo de geração de dados. O que se denomina (auto)etnográfico desenha essa pesquisa como um dos posicionamentos metodológicos que percorremos, reconhecendo a influência dos trajetos pessoais no processo de investigação. O caráter autoetnográfico que este estudo tem permite a análise da experiência pessoal a fim de entender a experiência social (ELLIS; ADAMS; BOCHNER, 2011, p. 273), abrindo passagem para que o leitor consiga ver o meu mundo como pesquisadora, através dos meus olhos.

Com o caráter "auto", consigo atender às questões que emergem do fato de eu não ser apenas uma participante observadora, como o seria em uma metodologia etnográfica comum. As próprias questões de pesquisa que surgiram ao longo da etapa de geração de dados vieram à tona por eu estar dentro do CEFET/RJ, trabalhando e vivendo as experiências junto aos participantes. Não faço apenas notas do que acontece e observo, mas vivo o que acontece. Não só entrevisto os membros daquele espaço, não só examino o modo de se falarem ou se relacionarem e não só investigo os usos dos espaços, mas estou nesses lugares físicos e simbólicos, eu falo, uso e me relaciono nesse espaço, percebendo criticamente as experiências.

Dentre as classificações de autoetnografia que Ellis, Adams e Bochner (2011, p. 278) sugerem, consigo fazer dialogar esta pesquisa com duas delas: a reflexiva e a etnografia narrativa. A primeira valoriza o próprio momento da entrevista, focando nas significações produzidas interativamente e nas dinâmicas emocionais ali presentes, considerando, inclusive, os próprios sentimentos da pesquisadora. A segunda classificação proposta pelos autores, ao qual me alinho neste estudo, refere-se às narrativas que possibilitam a afiliação das experiências do pesquisador nas análises etnográficas dos participantes. 
Chang (2008) cita a emersão da autoetnografia como uma poderosa ferramenta para pesquisadores que lidam com relações humanas, como educadores, sociólogos e profissionais de outras áreas, como a médica. Do mesmo modo, é preciso reconhecer que as experiências pessoais influenciam o processo de pesquisa de muitas formas, já que o pesquisador pode decidir pelo campo de estudo, os recursos e as circunstâncias pessoais que o motivam a estudar aquele objeto (ELLIS; ADAMS; BOCHNER, 2011, p. 274).

Nesta pesquisa de cunho (auto)etnográfico, conto com a experiência pessoal como modo de dar substância às experiências culturais vivenciadas por mim. Desse modo, busco tornar possível a exposição das especificidades culturais da comunidade estudada, possibilitando que essas características se tornem familiares ao leitor (ELLIS; ADAMS; BOCHNER, 2011, p. 273). Chang (2008, p. 43) defende que "a autoetnografia deve ser etnográfica em sua orientação metodológica, cultural em sua orientação interpretativa e autobiográfica em sua orientação de conteúdo", o que sustenta a minha ideia inicial de que o olhar não isento do pesquisador atravessa as orientações metodológica, interpretativa e de conteúdo do corpus desta pesquisa.

Partindo da ponderação de Ellis, Adams e Bochner (2011, p. 274) de que a autoetnografia "é uma das abordagens que reconhece e acomoda a subjetividade, a emotividade e a influência do pesquisador na pesquisa, em vez de se esconder dessas questões ou fingir que elas não existem", e com a reflexão iniciada nesta subseção, trazemos à tona o meu lugar de fala neste estudo, que será desenvolvido na subseção a seguir pelo questionamento sobre quem possui o direito de falar e que diferença existe no fato de ter sido falado, ou seja, qual é o meu local de fala neste estudo.

\section{3.}

\section{O (meu) local de fala}

Quando minha atuação no CEFET/RJ trouxe a possibilidade de abordar o tema das cotas, era evidente para mim a posição assimétrica que se apresentaria nas interações não só vividas no dia a dia do fazer da minha profissão, mas no momento interacional proposto para a geração de dados deste estudo, ou seja, a entrevista de pesquisa. Não só pelo cargo por mim ocupado na instituição, mas pelo local de onde falo, marcado pela posição social econômica que tenho 
atualmente, por ser parda ${ }^{16}$ (e não negra), mulher e por não ter sido "cotista" em nenhum ciclo de formação pelo qual passei (fui apenas bolsista parcial nas escolas particulares).

$\mathrm{E}$, ainda, temendo uma possível essencialização do racismo, assumo o risco de não desenvolver discussão sobre o tema, mas trago a reflexão de como a raça é relacional tanto no plano macrossocial quanto no microinteracional. A raça também é uma construção social discursiva e o racismo tem uma lógica colonial que está ligada à questão racial (BENTO, 2014). Portanto, o racismo é construído também na interação.

E é nesse contexto que justifico o diálogo do ponto localizado de onde falo, entendendo que há, implicitamente, um contrato de troca de enunciados. Esse contrato "confere aos protagonistas da relação discursiva respectivamente o estatuto de locutor, isto é, de falante autorizado a falar daquilo que fala e a falar do modo que fala, e o estatuto de ouvinte ou de leitor do discurso, isto é, de destinatário" (RODRIGUES, 1996).

$\mathrm{Na}$ linha Foucaultiana, refletir sobre o enunciador traz alguma intelecção sobre o lugar de fala, o qual nenhum outro tem "permissão" de ocupar. Foucault (1972, p. 65) formula sua reflexão questionando:

\begin{abstract}
[...] quem fala? Quem, no conjunto de todos os indivíduos-que-falam, está autorizado a ter esta espécie de linguagem? Quem é seu titular? Quem recebe dela sua singularidade, seus encantos e de quem, em troca, recebe, senão sua garantia, pelo menos a presunção de que é verdadeira? Qual é o estatuto dos indivíduos que têm - e apenas eles o direito regulamentar ou tradicional, juridicamente definido ou espontaneamente aceito, de proferir semelhante discurso?
\end{abstract}

Encontro na importância que Bakhtin (1990) dá ao contexto social a localização do enunciado neste processo, quando ele afirma que "a enunciação enquanto tal é um puro produto da interação social, quer se trate de um ato de fala determinado pela situação imediata ou pelo contexto mais amplo que constitui o conjunto das condições de vida de uma determinada comunidade linguística" (BAKHTIN, 1990, p. 121).

E como componente participante das interações sociais, não posso deixar de lado as intersecções que me constituem e me colocam em determinado lugar. Djamila Ribeiro (2017, p. 51) desenvolve sua reflexão sobre a importância de entender este lugar em que estamos, indicando que a luta contra as

\footnotetext{
${ }^{16}$ Esta é uma autodeclaração consciente de que, mesmo não me sentindo branca (tanto pela minha cor como por experiências de discriminações vividas por mim), posso ser lida socialmente como branca na maioria dos espaços por onde circulo.
} 
desigualdades ganha valor ao reconhecermos que partimos de lugares diferentes, pois experienciamos as situações de modo diferente. E por "experiências", a autora não define vivências individuais, mas o entendimento de "como o lugar social que certos grupos ocupam restringem oportunidades" (RIBEIRO, 2017, p. $61)$.

Entender e assumir o meu lugar neste processo de pesquisa é respeitar o locus social de grupos invisibilizados, enfrentando o fato de que a não universalização do meu ser enquanto pesquisadora, mulher, não cotista (e mais outras intersecções minhas) abre espaço para admitir que não deixei de ser beneficiada pelas opressões que infligem outros grupos como os alunos deste estudo (RIBEIRO, 2017, p. 68). Considero-me, então, localizada no grupo que detém o poder, em especial, por ocupar um cargo de gestão ao momento da geração de dados da minha pesquisa.

Não levo este posicionamento como problemático, mas atendo ao que Ribeiro (2017) sugere com a finalidade de ser leal ao locus social dos grupos que estudo e aproveito a possibilidade de autorreflexão, enquanto pesquisadora e mulher em posição privilegiada e hegemônica.

\section{4. \\ Procedimentos de pesquisa}

\subsection{1. Geração de dados}

Para atender aos objetivos da pesquisa, preconizei o meu contato direto com os participantes desde o convite para a entrevista até o momento da interação gravada em áudio. Para que fosse possível iniciar a fase de geração de dados, foi necessário o pedido de autorização para realização da pesquisa dentro do CEFET/RJ, pelo diretor geral, que prontamente autorizou via processo interno de pedido de autorização de pesquisa. É de interesse da instituição que seu espaço escolar seja objeto de estudo, tendo em vista que os resultados das pesquisas que envolvem os alunos acabam servindo, como objetivo paralelo, de possibilidade de melhoria para os próprios processos pedagógicos internos.

É fato que o cargo que ocupava facilitou a abertura para a minha entrada em um campo além do dia a dia do meu trabalho. Mergulhar nas profundezas das 
histórias que constroem e reconstroem vidas, as mesmas com que lidamos todos os dias no departamento de ensino, é tão apaixonante quanto inquietante. Estar dentro do CEFET/RJ para poder explicar minha intenção de pesquisa a todos os atores que têm o poder da autorização para o estudo no campo, sem dúvidas, facilitou todo o processo de entrada na instituição para além do tempo de minha rotina laboral.

Outra vantagem da minha presença constante como coordenadora e pesquisadora foi a possibilidade de misturar esses papeis ao sabor das experiências que vivo lá dentro, percebendo essa mistura e seus atravessamentos. Assim, consigo vivenciar um campo de observação mais amplo e, desde o início da pesquisa, os olhos passaram a ser mais atentos em cada presença de pessoas e em espaços. De certa forma, as histórias contadas não eram desconhecidas por mim. A cada entrevista que apareciam entrelaçamentos de experiências, citações de pessoas de forma mútua (em entrevistas separadas) ou a cada isenção de exposições de opinião, sentia-me dentro das histórias, como quem costura uma colcha de retalhos.

Ao mesmo tempo, e de modo dicotômico, o fato da presença da assimetria entre mim e os participantes, alunos e docentes, trouxe um medo que pairava em momentos anteriores e posteriores aos momentos de interação gravada. De modo que julgo interessante, os participantes pareciam fazer questão de expor seus medos: da gravação, de ser analisado, de falar mal de alguém, de ficar nervoso e de ser "racista". O trabalho de face ${ }^{17}$ (GOFFMAN, 2011) dos participantes já era iniciado antes mesmo da interação gravada.

\subsubsection{1. Seleção dos participantes}

O convite aos participantes para a entrevista para esta pesquisa foi realizado da seguinte forma: para os alunos, o acesso ao sistema que eu já tinha facilitou a localização dos "cotistas", de modo que o convite foi direcionado primeiramente àqueles do grupo 05 (escola pública + negros, pardos e indígenas + renda inferior

\footnotetext{
${ }^{17}$ Segundo Biar (2015, p. 132), Goffman conceitua o dinamismo do self a partir do conceito de face como sendo o valor social positivo que o sujeito reivindica para si. As estratégias para que os padrões esperados e positivos sejam mantidos em uma interação são realizadas através do trabalho de face, que corresponde a determinados padrões verbais e não verbais de expressão, que são guiadas e sustentadas por sua própria impressão do encontro social onde a interação está acontecendo.
} 
a 1,5 salário mínimo). Em turmas em que não havia alunos do grupo 05, direcionei o convite aos grupos 04 e 03 (escola pública + negros, pardos e indígenas; escola pública + renda inferior a 1,5 salário mínimo, respectivamente); já com os docentes, busquei um por área, direcionando o convite aos docentes que participaram da modalidade anterior à Lei de Cotas e que permaneciam lecionando na modalidade integrada, após a Lei (BRASIL, 2012).

O convite aos docentes não foi por afinidade pessoal, e o critério de escolha acabava sendo localizado situacionalmente. Alguns convites aos docentes para participarem da pesquisa foram feitos após reuniões de equipes ou de conselhos deliberativos $^{18}$ em que eu percebia, em suas falas nessas reuniões, que 0 professor tinha experiências em momentos anterior e posterior às cotas. Outros convites foram feitos após minhas lembranças e anotações pessoais de falas dos docentes sobre alunos, nos conselhos de classe. A minha curiosidade aguçada para receber novas narrativas desses docentes com falas "intrigantes" em conselhos de classe guiaram boa parte dos convites.

Expliquei a pesquisa já no convite aos participantes, que foi realizado de modo pessoal. No momento em que eu começava a gravar a interação, explicava novamente a pesquisa de modo ainda mais detalhado e deixava em aberto a possibilidade de questionamentos e dúvidas sobre o tema da tese. O local que escolhi para as gravações foi uma pequena sala de reuniões dentro do CEFET/RJ, situada próxima às coordenações de disciplina, a qual era trancada para não haver interrupções ao longo da entrevista. O período de geração de dados foi de novembro de 2016 a julho de 2017. Após cada entrevista, as minhas impressões e sentimentos eram registrados em um diário de campo, que são expostos aqui em alguns momentos de abertura de capítulos. O detalhamento sobre os dados gerados encontra-se exposto na subseção 3.4.2. deste capítulo.

\footnotetext{
${ }^{18}$ As instituições federais de ensino apresentam conselhos deliberativos em diversas instâncias, que não somente auxiliam os departamentos nas decisões mais difíceis, mas tentam garantir a gestão democrática por intermédio dessas reuniões. No CEFET/RJ Maracanã, temos o CONDMET (Conselho de Docentes do Ensino Médio e Técnico). As reuniões ordinárias são mensais, com datas delimitadas no calendário, fora as extraordinárias, e cada área e disciplina possui um representante que deve representar a opinião e decisão de suas equipes de colegiados docentes.
} 


\subsubsection{2. Entrevistas}

As entrevistas, nesta pesquisa, têm função para além de método de geração de dados. A entrevista é tomada, neste estudo, como o próprio evento de fala, considerando as especificidades discursivas que estão no momento interacional dessa etapa de geração de dados da pesquisa. Essas particularidades presentes na interação dão conta de atender a determinadas regras que cercam o discurso em contextos variados (HYMES, 1972, 1981 apud MISHLER, 1991, p. 35).

Conforme discutido na seção 3.1., destaco a importância do olhar sobre o "micro" nesta pesquisa. Os itens que emergem da interação face a face (GOFFMAN, 2011) podem conter elementos macrossociais que situam o discurso do participante em seu tempo histórico e no espaço. Na microinteração, por sua vez, encontram-se, dentre outros, aspectos de assimetria que indicam a identidade macro da instituição em estudo. Foram consideradas, então, as negociações envolvidas no processo de geração de dados, desde o convite aos participantes até o momento das entrevistas.

A opção por localizar a entrevista como evento de fala nesta tese traz, então, a possibilidade de convergir as minhas perspectivas e a dos participantes. Hoeltgebaum, Godoi e Lenzi (2012, p. 97) desenvolvem a ideia de que "aceitar os pensamentos múltiplos e a subjetividade de cada discurso contribui para a construção do objeto, uma vez que cada entrevista possibilita ao pesquisador reviver, com nova versão, os acontecimentos". Assim, como já dito, ofereço uma perspectiva êmica de investigação, através da qual pretendo orientar as análises das entrevistas gravadas, atendendo às categorias selecionadas, conforme explicarei na subseção 3.4.3..

Seguindo esta reflexão, os excertos de análise são uma representação parcial do que ocorreu no momento interacional (MISHLER, 1991, p. 48) e é esta concepção que sigo em minha tese, considerando que sobre o próprio evento de fala, recaem, também, categorias de análise. A eleição da mesclagem entre entrevista semiestruturada e em profundidade proporcionou maior leveza na etapa de geração de dados, tornando o processo mais dinâmico e natural.

A entrevista semiestruturada pressupõe uma espécie de roteiro, no qual constam perguntas principais que se complementam por questões que possam surgir no momento da entrevista. Dessa forma, parece acontecer uma conversa mais espontânea, sem respostas que possam padronizar-se a possibilidades 
previamente delimitadas (MANZINI, 1990/1991, p. 154). Com a entrevista em profundidade, busco entender como os assuntos são percebidos pelos participantes. Na próxima subseção, explico com maior detalhamento as características sobre os participantes desta pesquisa.

\subsubsection{3.}

\section{Os participantes das entrevistas}

Os participantes docentes têm formações entre mestrado e doutorado e se relacionam comigo hierarquicamente enquanto coordenadora, diante do cargo que eu ocupava no momento da geração de dados. Cabe acrescentar que, frente à concepção de coordenação pedagógica apresentada, a qual nos alinhamos no departamento de ensino médio e técnico, em geral tenho relação amistosa com os docentes, o que facilitou a aceitação aos convites de participação na pesquisa.

Dos 16 alunos entrevistados, 7 entraram através de cota com componente racial, o que também corresponde, superficialmente, à quantidade geral relacionada de negros na escola. Dos demais alunos, 8 entraram através de cota com componente de baixa renda e 1 entrou por cota de origem escolar pública sem nenhum dos outros dois componentes (racial ou social). Cabe ressaltar que nem todas as turmas têm matriculados alunos de cotas do grupo 05. Por motivo de atenuar a burocracia que envolve pesquisa com menores de idade, optei por selecionar as turmas de $4^{\circ}$ ano para realizar os convites de participação. Os alunos do último ano passaram, também, por mais tempo de vivência na instituição como alunos oriundos da política de cotas. Nessas turmas, os alunos já são maiores de idade, o que facilitou o processo de geração de dados.

Infelizmente, por razões de tempo e espaço de tese, somente as entrevistas com os docentes foram o foco desta pesquisa. Apesar de eu optar por deixar registradas as informações sobre as entrevistas com os alunos, esses dados não foram analisados para a tese. Os alunos ilustraram os contrapontos e, além de suas entrevistas servirem como abertura dos capítulos, auxiliaram substancialmente, também, como parte do contexto e entendimento maior sobre quais estigmas existiam sobre os alunos "cotistas". Os próprios alunos ofereceram elementos que explicitaram como eles mesmos são vistos, descritos e esperados pela comunidade escolar e isso será explorado em trabalhos futuros. 


\title{
3.4.2. Procedimentos de análise
}

Dada a possibilidade de encaminhar diversas direções analíticas para os dados gerados, as análises foram realizadas em camadas, de modo que possibilitem olhares de diferentes ângulos sobre a interação proposta. A escolha de realizar um recorte analítico com mais de uma categoria selecionada auxiliará no alinhamento aos objetivos iniciais traçados para a pesquisa. Nesta subseção, detalho os procedimentos metodológicos de entrevista, a transcrição de dados e as categorias selecionadas para o recorte analítico.

\subsubsection{1.}

\section{Transcrição dos dados}

\begin{abstract}
Entendo que os primeiros movimentos de análise começam no momento da seleção dos dados a serem transcritos. Conforme argumenta Mishler (1991, p. 48) "cada transcrição inclui algumas e exclui outras características da fala e reorganiza o fluxo de fala em linhas de texto dentro dos limites de uma página". Em minha pesquisa, optei por transcrever todas as entrevistas em sua íntegra. Esta foi a forma que encontrei de lançar o olhar mais apurado para cada entrevista gravada de modo que, enquanto realizava a transcrição bruta, era necessário parar em vários momentos para reouvir o que estava sendo narrado. Considerei este processo inicial de suma importância para que o primeiro contato com as gravações tivesse uma atenção mais refinada.
\end{abstract}

As convenções de transcrição que utilizei nas transcrições são as de Schnack, Pisoni e Ostermann (2005), expostas no Anexo A. Nas transcrições, detalhes paralinguísticos da fala como pausas e micropausas, interrupções, sobreposições de fala e alongamentos de vogais foram considerados importantes para as análises. Mishler (1991, p. 50) descreve essa importância quando cita que "os procedimentos sistemáticos de transcrição são necessários para a análise e interpretação válidas dos dados de entrevistas".

A partir da transcrição, com todo o material bruto em mãos e já tendo direcionado um olhar detalhado sobre todas as entrevistas, passei a reouvir as entrevistas uma a uma, anotando as partes que chamaram mais atenção no que 
se referia especificamente ao tema de pesquisa. Da totalidade dos dados, apenas os excertos narrativos que tematizavam as cotas foram selecionados para análise.

\subsubsection{2.}

\section{Caracterização geral dos dados}

Para atender aos objetivos traçados para esta pesquisa, foram realizadas 29 entrevistas, sendo 16 delas com alunos "cotistas" e 14 com docentes, conforme Tabelas 1 e 2. Com o total de 29 arquivos de gravação, há, aproximadamente, 14 horas de entrevistas gravadas em áudio, conforme mostrado nessas tabelas. As entrevistas foram realizadas de acordo com a disponibilidade de tempo que os participantes apresentaram, tendo o período de gravações ocorrido de novembro de 2016 a julho de 2017. Foram explicitados, em momento anterior às gravações, todos os direitos que os participantes tinham, inclusive sobre sua desistência de participação a qualquer momento da pesquisa. Até a presente data, nenhum participante solicitou a exclusão dos dados gravados ${ }^{19}$.

Tabela 1: Caracterização dos Dados / Alunos $^{20}$.

\begin{tabular}{|c|c|c|c|c|}
\hline Entrevista & Cota & Participante & Duração & Tópicos/blocos temáticos \\
\hline Marcos & 03 & Allane & $50^{\prime} 42^{\prime \prime}$ & 1. Sentimento ao passar para o CEFET/RJ. \\
\hline Marcela & 04 & Allane & $33^{\prime} 15^{\prime \prime}$ & \multirow{2}{*}{ Dificuldades encontradas no $1^{\circ}$ ano. } \\
\hline Vinícius & 05 & Allane & $09^{\prime} 01^{\prime \prime}$ & \\
\hline Laís & 04 & Allane & $27^{\prime} 01^{\prime \prime}$ & \multirow[t]{2}{*}{ 3. Sentimentos vividos no $1^{\circ}$ ano. } \\
\hline Guilherme & 04 & Allane & $17^{\prime} 52^{\prime \prime}$ & \\
\hline Gilberto & 04 & Allane & $30^{\prime} 12^{\prime \prime}$ & \multirow{3}{*}{$\begin{array}{l}\text { 4. Situações de percepção de tratamento } \\
\text { diferenciado recebido pelos alunos e } \\
\text { pelos docentes. }\end{array}$} \\
\hline Isadora & 04 & \multirow{2}{*}{ Allane } & \multirow{2}{*}{$36^{\prime} 55^{\prime \prime}$} & \\
\hline Luana & 04 & & & \\
\hline Luciano & 05 & Allane & $22^{\prime} 32^{\prime \prime}$ & \multirow{2}{*}{$\begin{array}{l}\text { 5. Descrição de situações de discriminação } \\
\text { vividas. }\end{array}$} \\
\hline Aline & 04 & Allane & $21^{\prime} 19^{\prime \prime}$ & \\
\hline Suzana & 02 & Allane & $27^{\prime} 21^{\prime \prime}$ & \multirow{2}{*}{$\begin{array}{l}\text { 6. Descrição de situações de discriminação } \\
\text { conhecidas/presenciadas. }\end{array}$} \\
\hline Leonardo & 05 & Allane & $17^{\prime} 59^{\prime \prime}$ & \\
\hline Yasmin & 04 & Allane & $28^{\prime} 51^{\prime \prime}$ & \multirow{2}{*}{ 7. Opinião sobre cotas. } \\
\hline Cintia & 03 & Allane & $30 \prime 50^{\prime \prime}$ & \\
\hline Claudio & 03 & Allane & $17^{\prime} 01^{\prime \prime}$ & 8. Opinião sobre coletivos negros. \\
\hline
\end{tabular}

Fonte: Elaborado pela autora por meio de dados da pesquisa.

\footnotetext{
${ }^{19}$ A pesquisa foi submetida à Comissão de Ética em Pesquisa da PUC-Rio e, em 26 de julho de 2017, obteve parecer favorável para o seu desenvolvimento.

20 Os nomes dos participantes, tanto alunos quanto servidores, foram modificados, a fim de atender aos critérios da Comissão de Ética e a fim de proteger a identificação dos entrevistados.
} 
Tabela 2: Caracterização dos Dados / Docentes/Equipe Pedagógica.

\begin{tabular}{|c|c|c|c|}
\hline Entrevista & Participante & Duração & Tópicos/blocos temáticos \\
\hline Laura & Allane & $46^{\prime} 06^{\prime \prime}$ & \multirow{3}{*}{$\begin{array}{l}\text { 1. Sentimento ao saber que haveria a entrada de } \\
\text { alunos "cotistas". }\end{array}$} \\
\hline Luciano & Allane & $41^{\prime} 39^{\prime \prime}$ & \\
\hline Ana & Allane & $37^{\prime} 38^{\prime \prime}$ & \\
\hline Gabriela & Allane & $32^{\prime} 24^{\prime \prime}$ & Mudanças realizadas ou não nas práticas \\
\hline Afonso & Allane & $29^{\prime} 02^{\prime \prime}$ & \\
\hline Vicente & Allane & $21^{\prime} 21^{\prime \prime}$ & Mudanças realizadas ou não na estrutura \\
\hline Júlio & Allane & $284^{\prime \prime}$ & curricular. \\
\hline Paloma & Allane & $45^{\prime} 04^{\prime \prime}$ & 4 Pensamentos sobre os novos alunos \\
\hline Jonas & Allane & $33^{\prime} 31^{\prime \prime}$ & \\
\hline Pedro & Allane & $41^{\prime} 59^{\prime \prime}$ & 5. Descrição de situações de discriminação \\
\hline Eduardo & Allane & $44^{\prime} 00^{\prime \prime}$ & conhecidas/presenciadas. \\
\hline Jeremias & Allane & $17^{\prime} 29^{\prime \prime}$ & 6. Opinião sobre cotas. \\
\hline Marcelo & Allane & $27^{\prime} 48^{\prime \prime}$ & \\
\hline Edson & Allane & $24^{\prime} 39^{\prime \prime}$ & Opinião sobre coletivos negros. \\
\hline Rafaela & Allane & $28^{\prime} 27^{\prime \prime}$ & \\
\hline
\end{tabular}

Fonte: Elaborado pela autora por meio de arquivos com dados da pesquisa.

Após geração de dados, transcrição das entrevistas, ensaios de análises das narrativas e discussão em exame de qualificação, a tese tomou um caminho diferente dos objetivos engendrados que motivaram de início esta pesquisa. Em um primeiro momento, a ideia era focar principalmente nas narrativas dos alunos, colocando a lente sobre elementos interacionais de construção de identidade através dos estigmas recebidos por eles. Porém, ao me deparar com as narrativas dos docentes, percebi a importância de entender o porquê do Discurso estigmatizante sobre as cotas, antes de olhar para como os alunos se sentiam quando ouviam deliberadamente esse discurso. $\mathrm{E}$, assim, encontrei mais sentido e importância social para a minha pesquisa. Na próxima seção, explico como foi realizada a seleção dos excertos para o capítulo de análise.

\subsection{3.}

\section{Recorte analítico e categorias selecionadas}

Já que esta pesquisa se apoia em mecanismos interpretativos alicerçados na minha experiência no campo, a análise de narrativa é informada pela sociolinguística interacional. Mais especificamente, é utilizada como categoria a identificação da narrativa (LABOV, 1972), em interface com os pressupostos do 
Sistema de Avaliatividade (MARTIN; WHITE, 2005), os sistemas de coerência (LINDE, 1993), o conceito de estigma (GOFFMAN, 1988) e as estratégias retóricas de Wodak et al. (2003), vindas da Análise Crítica do Discurso. Em diálogo com a concepção de bricolagem (DENZIN; LINCOLN, 2006, p.17-18), e conforme já explicitei nessa tese, pretendo realizar o entrecruzamento de teorias analíticas.

Explicando mais detalhadamente, logo após as transcrições terem sido concluídas por mim, me dei conta de que havia uma série de narrativas sendo enunciadas nas entrevistas. Após a seleção e excertos referentes às cotas e as caracterizações dos alunos "cotistas", percebi que os mecanismos de avaliação sobre os alunos e sobre as cotas tomavam peso nas histórias contadas. Não eram apenas histórias vividas, sabidas, reportadas. Havia uma carga avaliativa forte e eminente nessas histórias, sejam elas a favor ou contra as cotas.

Foi necessário, então, averiguar nos dados se esses itens de avaliação eram recorrentes nas narrativas de todos os docentes entrevistados. Então, percorri mais algumas vezes as entrevistas transcritas, acompanhando a leitura junto aos áudios gravados, para destacar os itens que mais se aproximavam de avaliações ou julgamentos sobre os alunos e sobre as cotas. Percebi, neste momento, que seria necessário um aporte teórico sobre avaliação no discurso e resolvi combinar a Análise de Narrativa com o Sistema de Avaliatividade.

Após realizar o trabalho de localização dos itens de avaliação e das características sobre os alunos "cotistas" que apareceram nas entrevistas, selecionei duas grandes narrativas para analisar e apresentar para a banca de qualificação. Na qualificação foram apontados aspectos de extrema importância para a continuação da minha pesquisa, dentre eles, a necessidade de um encaminhamento crítico em minha análise. Até então, o olhar que eu havia dado aos dados era bastante descritivo, sem muitos mergulhos questionadores sobre os itens de avaliação nas histórias.

A minha ida ao doutoramento sanduíche foi, então, decisiva para esse aspecto sobre as análises das narrativas. Na Universidade de Copenhague, tive contato com os conceitos de Análise Crítica do Discurso que dariam base para uma análise crítica das narrativas da minha pesquisa. Mais à frente, ainda neste capítulo, conto de forma detalhada como se deu este processo junto ao Professor Doutor Georg Wink.

Por fim, decidi refletir sobre a relação micro/macro através da teorização dos sistemas de coerência de Linde (1993), fechando, assim, o conjunto teórico para análise dos meus dados. A partir da definição das combinações de teorias que seriam utilizadas em minha tese, parti para a realização de um trabalho de 
selecionar de forma minuciosa todos os itens que faziam parte de estratégias retóricas discursivas (WODAK et al., 2009) para, quando do retorno ao Brasil, selecionar quais narrativas fariam parte da composição do capítulo de análise desta tese.

Mais uma vez, decidi por reouvir todas as entrevistas, acompanhando os áudios com as transcrições para selecionar quais narrativas entrariam no capítulo de análise da pesquisa. Realizei uma categorização dos dados de modo a expor os itens de avaliação que apareciam de forma ordinária nas entrevistas. Tendo categorizadas a frequência ${ }^{21} \mathrm{com}$ que esses itens apareciam, selecionei as narrativas mais canônicas que melhor exemplificariam as reflexões que encaminho em cada análise. Com o intuito de organizar as etapas de análise, as listo a seguir:

1. Análise de narrativa. Através da estrutura proposta por Labov (1972), a primeira etapa de análise se dedicou a entender como as narrativas se estruturam, buscando as regularidades que nelas aparecem. Além da estrutura narrativa, será dada atenção aos sistemas de avaliação presentes nas construções narrativas dos participantes, através das categorias do Sistema de Avaliatividade (MARTIN; WHITE, 2005). Esta etapa de análise se ancora/baseia nas caracterizações sobre os "cotistas" oferecidas pelos docentes em suas narrativas e se relaciona ao segundo objetivo específico que exponho no início do capítulo 3 , no posicionamento metodológico da pesquisa.

2. Identificação das estratégias retóricas. Aqui, utilizo a organização de estratégias retóricas elaborada por Wodak et al. (2009) para localizar a dimensão discursiva da construção dos estigmas dos alunos. Neste momento, há a transversalidade teórica com o Sistema de Avaliatividade, ao serem localizados os itens que apontam para os estigmas. Aqui, também, identifico e posiciono os discursos de manutenção de determinada ordem social.

3. Análise das relações micro e macro. Nesta fase, iniciei a busca das relações entre os aspectos microinteracionais com as construções ideológicas (sistemas de coerência) (LINDE, 1993) da comunidade escolar e, quando possível, sua extrapolação para as construções ideológicas/culturais de sociedade.

\footnotetext{
21 A frequência a que me refiro aqui não é a quantitativa, mas que apenas demonstram a ordinariedade de construções discursivas que apontaram para os índices sobre a política de cotas e sobre os alunos "cotistas".
} 
$\mathrm{Na}$ próxima seção, exponho as questões éticas e políticas da minha pesquisa.

\section{5. Questões éticas e políticas da pesquisa}

Tendo em vista meu duplo papel, enquanto pesquisadora e membra da instituição, que tomo como objeto, as questões éticas são diversas e bem delicadas. Sendo assim, seria inevitável que muitos elementos sensíveis fossem emergindo ao longo da pesquisa, desde o início. A própria escolha de tema da tese já é uma questão ética complexa, lembrando que o mote tanto para o título quanto para o desenvolvimento do tema foi uma reunião de conselho de classe e a fala de uma docente. Posso dizer que já por isso tenho o receio de que a própria docente se identifique ao ler o título da minha tese, apesar da reunião estar cronologicamente distante da defesa desta tese em si.

Outra questão que penso ter se apresentado está nos entrelaçamentos das histórias contadas e dos próprios atores envolvidos e projetados por diferentes participantes, de diferentes formas ao longo das próprias entrevistas. É interessante notar que alguns participantes citam outros que também participaram da pesquisa, mesmo que os convites tenham sido aleatórios, e não sendo realizados posteriormente à citação de algum participante. Um rápido exemplo disso é o caso de uma aluna citando determinado professor que teve um problema com uma turma específica: ao entrevistar esse mesmo docente, ele cita a turma da aluna que o mencionou, identificando a turma como problemática. Esses entrelaçamentos de histórias e alusão mútuas já mostram um possível problema ético da pesquisa e, por este motivo, todos os nomes foram trocados por outros nomes fictícios e completamente diferentes do original, para não restar qualquer semelhança.

Uma terceira questão ética é a própria assimetria entre mim e os participantes pesquisados, devido ao cargo que eu ocupava na instituição. É relevante atentar para os aspectos micros da interação que comunicam as relações de poder que passeiam no momento da gravação proposta, inclusive oferecendo olhar atento aos momentos de reenquadre à situação de entrevista. Esses momentos se fizeram presentes em muitas gravações, tendo em vista as mudanças de posicionamento situacional em meio às conversas gravadas devido 
aos alinhamentos, por mim e pelos entrevistados, aos sistemas de coerência da comunidade escolar da qual fazemos parte.

A própria abordagem dos docentes para as entrevistas também é um problema ético, tendo em vista que um dos parâmetros de escolha dos participantes da pesquisa foi exatamente as falas polêmicas dos docentes nas reuniões. Caso esses docentes leiam essa tese, por exemplo, no capítulo de metodologia estará explícito que este parâmetro de seleção o identificou como um potencial docente cujo discurso em alguma reunião foi questionável ou questionado por mim.

Além da problemática da assimetria interpessoal trazida pelo meu cargo, identifico outro problema importante na própria abordagem para a entrevista de pesquisa no que se refere ao tema. Discutir cotas, discriminação de minorias e racismo com pessoas que são potencialmente racistas já é, por si só, uma questão ética delicada. Digo isso em relação ao local de fala dos docentes que são, em sua esmagadora maioria, brancos e de classe social acima dos alunos "cotistas" sobre os quais falamos nas entrevistas de pesquisa. Somente um docente entrevistado nesta pesquisa de doutorado é negro, devido à escassez de docentes negros na instituição conjugado à aceitabilidade de participação para esta pesquisa.

Mais outra questão ética importante é o uso do próprio termo "cotista". Como já disse logo ao início desta tese, na introdução, utilizo o termo já sabendo que ele é um índice sobre as cotas, e é amplamente utilizado no Brasil. O aluno apenas é "cotista" durante o concurso para acesso ao CEFET/RJ. A partir do momento em que ele entra e se matricula na escola, não é mais "cotista". Dessa forma, para esta pesquisa, eu utilizo dados internos dizendo aqui quem é "cotista", mesmo já sendo aluno matriculado na escola, e quem não é. E isso é um dado interno ao qual somente tenho acesso por estar na coordenação pedagógica do departamento. Este dado, inclusive, não é publicado pelo departamento justamente para não haver problemas de segregação entre os alunos.

É importante ressaltar que o que ocorre dentro do CEFET/RJ, inclusive, não está permitido em qualquer regulamento ou convenção ética. Quando os alunos sabem quem é "cotista" e quem não é, isso é fruto de pesquisas individuais por meio de dados de transparência pública, e não por divulgação da escola. O aluno se matricula e, ainda assim, continua rotulado como "cotista". Essa etiqueta transferida a ele não sai ao longo do Ensino Médio inteiro e eu, como pesquisadora, me apropriei dessas etiquetas para a minha pesquisa, fazendo uso 
do termo. Como servidora da escola, obviamente, também me aproprio dessa etiqueta como identificação dos alunos.

O valor de julgamento no termo será feito ao longo das análises das narrativas, no capítulo 5, mas exponho aqui o problema ético que o próprio termo causa, a partir do momento em que, a partir dele, acabo selecionando e expondo quem acessou a escola pela política de cotas. Não pelos nomes, pois os nomes citados foram trocados ao longo de toda a tese, mas por ter trabalhado somente com os "cotistas" e os docentes. Conforme explico aqui, a seleção de quais alunos seriam entrevistados se deu a partir de uma lista interna do departamento impressa do sistema de alunos, a qual somente eu e o chefe do departamento temos acesso, através de senha.

Nesse sistema, é explicitada, então, qual cota o aluno utilizou para acessar o CEFET/RJ. Lembrando que, por decisão do departamento, esses dados não foram publicados devido à possibilidade de discriminação, caso os docentes e alunos soubessem quem utilizou a política e quem não utilizou. Pela delicadeza com que esses dados devem ser tratados, a solução encontrada por mim foi a de, novamente, modificar sistematicamente todos os nomes dos entrevistados. Foram escolhidos codinomes completamente diferentes foneticamente dos nomes originais, para que o sigilo das identidades fosse garantido.

No próximo capítulo, desenvolvo a fundamentação teórica estudada e utilizada por mim para formar a base conceitual e metodológica aos dados que foram analisados no capítulo 5. 


\section{4 \\ Fundamentação teórica}

"Eu estava na sala, não era aula dele, ele passou na sala abriu a porta apontou pra mim e falou 'eu vou dar um pente pra pentear o cabelo dessa menina' pro professor de matemática... ninguém riu na sala, o professor de matemática 'a um absurdo'... e ele fechou a porta, riu da minha cara, fechou a porta e saiu andando... aí eu não gritei nem nada... saí da sala, conversei com ele, falei que não achava bom o posicionamento dele, o que ele falou pra mim, achava que era racismo sim e no momento que outra pessoa não gosta da brincadeira um só não é brincadeira, se torna bullying ou algo do tipo... e ele falou que de forma alguma era racista porque a mãe dele era negra e que ele tinha o físico de negro, o cabelo, o nariz e eu não estendi, né, porque não ia mudar nada no primeiro momento."

(Trecho da entrevista realizada com Cintia aluna participante desta pesquisa)

Para o entendimento geral e mais organizado da arquitetura teórica que realizo em minha tese, abaixo apresento o Esquema 2, que reúne as teorias que trarei para discussão no presente capítulo e que serão base para as análises dos dados.

Esquema 2: Desenho da arquitetura teórico-metodológica da tese.

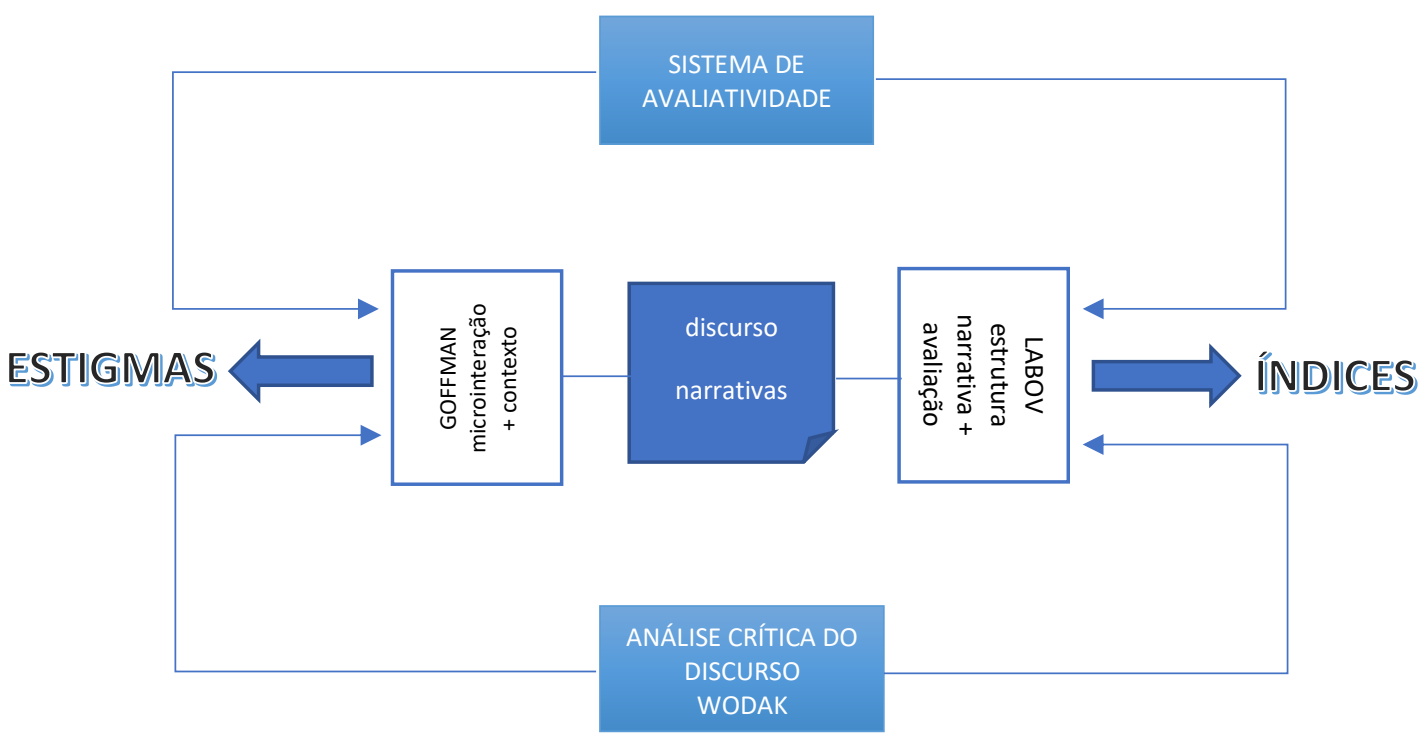

Fonte: Elaborado pela autora (2020). 
4.1.

A Narrativa e as (re)construções sociais e pessoais

Vindo da área de educação por formação inicial, meu contato com os estudos narrativos ainda é embrionário. Entender que as narrativas estão não somente em nossa rotina, mas em nossa construção identitária e interrelacional, se apresentou cada vez mais fascinante ao longo das disciplinas de doutorado que fiz nos quatro anos de estudo e de pesquisa. Os significados simplificados e rasos sobre narrativa que se aprende na escola foram dando lugar a autores que não somente descreveram a estrutura das histórias que se conta, mas que formalizaram as teorias narrativas. Da mesma forma, o valor discursivo que as narrativas têm trouxe mais sentido ainda à articulação de teorias que proponho nesta pesquisa.

Riessman (1993, p. 4) lembra que o histórico dos estudos narrativos na sociologia qualitativa não é recente, sendo oriundo da Escola de Chicago, e o que os diferenciam dos estudos etnográficos tradicionais é a atenção dada aos eventos, e não às histórias que o narrador cria sobre eles. É sob a perspectiva do evento narrado, sob o olhar político-social do contexto, que dou ênfase à prática discursiva da narrativa nesta pesquisa. E é essa relação com a prática discursiva que somente me dei conta após o aprofundamento da teoria sobre as narrativas durante as aulas.

Agora, pensando na estrutura narrativa em si, conheci, através da disciplina Análise de Narrativas, a proposta de Labov (1972). Segundo a teoria Laboviana, a arrumação dos eventos narrados é marcada por uma sequência verbal em tempo ordenado. Para Labov (1972, p. 359-360), a narrativa como "um método de recapitulação de experiências passadas através de uma combinação verbal sequencial de palavras para a sequência de eventos que (supostamente) ocorreram verdadeiramente"22. As histórias escolhidas para serem narradas constituem-se em histórias contáveis, e apresentam um ponto que o narrador interpreta como algo a ser compartilhado. Para Georgakopoulou (1997, p. 5) as "narrativas tendem a recontar eventos notáveis, ou seja, surpreendentes, perturbadores, interessantes, ou, por outro lado, eventos contáveis"23.

22 Tradução livre minha de Labov (1972, p. 359-360). Texto original: We define narrative as one method of recapitulating past experience by matching a verbal sequence of clauses to the sequence of events which (it is inferred) actually occurred.

${ }^{23}$ Tradução livre minha de Georgakopoulou (1997, p. 5).Texto original: [...] narratives tend to recount noteworthy events, that is, surprising, disturbing, interesting, or, otherwise, tellable events. 
Além disso, Labov (1972) esquematizou o formato canônico de se contar histórias, ao perceber que havia um padrão nas diferentes formas de narrar. A essas características comuns da narrativa ele denominou resumo, orientação, ação complicadora, avaliação, resolução e coda. Esses elementos organizativos da narrativa colaboram com a formação de significado das experiências vividas (SANTOS, 2016). Compreender isso fez toda a diferença para entender por onde eu deveria iniciar as minhas análises, tendo em vista que era necessário entender, primeiro, como os docentes estavam significando as cotas e os alunos "cotistas".

Resumidamente, explico o que é esperado de cada elemento da estrutura narrativa proposta por Labov (1972). O primeiro elemento da narrativa é o resumo ou sumário, que corresponde ao ponto inicial da história e a resume. O segundo segmento é a orientação, através do qual o narrador orienta a história a ser narrada com alguns dados de seu contexto, como as personagens, o local e o espaço temporal. A orientação é seguida pela ação complicadora, que basicamente é o evento principal ocorrido. Neste momento, podem-se encontrar, também, pontos de virada ${ }^{24}$ (MISHLER, 2002). No segmento da avaliação, estão presentes, como o próprio nome diz, as perspectivas avaliativas do narrador em relação ao que foi contado. Na resolução, é oferecido o desfecho da história com encaminhamentos sobre o encerramento do evento. A narrativa é finalizada com a coda, que traz a narrativa passada ao tempo real da narração, constituindo-se como uma avaliação mais geral.

É importante explicar que o modelo Laboviano tem suas limitações. As principais críticas dirigidas a ele giram em torno da sua abordagem estruturalista, que acaba sendo mais descritiva e autônoma em relação ao contexto sociocultural em que ela se apresenta. Por este motivo, nesta seção sobre narrativa, explico a sua relação com o locus social que a posiciona dentro de contextos.

As narrativas reorganizam as histórias experimentadas no passado e ao mesmo tempo trazem oportunidade de entender ou criar o sentido desse passado através de formas individuais de interpretação (RIESSMAN, 2008, p. 61). Para Labov (1972, p. 354), as narrativas trazem a possibilidade de se reviver eventos do passado, e a recriação de si temporalmente organizada (RABELO, 2011, p. 184) possibilita a reinterpretação das próprias histórias de vida, aprofundando as reflexões sobre essa (re)construção identitária. Nesta tese, será necessário, para

\footnotetext{
24 Segundo Mishler (2002, p. 107), os pontos de virada são "incidentes que muitas vezes ocorrem de modo repentino e inesperado" dentro da narrativa, trazendo novo sentido à compreensão do sujeito sobre a experiência contada.
} 
as análises que faço, compreender as (re)organizações sobre o tema de cotas nas histórias dos docentes.

Essa (re)construção vem atravessada por ações que incluem o modo como escolhemos nos projetar ao outro dentro de uma determinada unidade social. Isso significa que o repertório de histórias que o indivíduo escolhe para contar não só constrói o self (GOFFMAN, 1988) que ele deseja projetar, mas reconstrói sua própria identidade, encaixando-a nas novas unidades sociais reconhecidas por ele como tais. Essa identidade não somente significa o que o docente é naquele momento da interação da entrevista, mas entendo ser uma construção que elabora e executa determinada prática discursiva ressignificada.

Para este estudo, a narrativa é tomada, então, como prática discursiva, abrindo espaço para a "compreensão da relação entre discurso, identidade e sociedade" (FABRÍCIO; BASTOS, 2009, p. 41-42). Observando que "narrar é atividade das mais centrais e mais comuns na vida cotidiana" (GARCEZ, 2001, p. 190), entendo que, ao se contar e recontar histórias, as experiências e os conhecimentos são organizados socioculturalmente.

Não somente a organização temporal da experiência tem importância quando se narra uma história, visto que o fato narrado vem mergulhado em nuances morais de quem o conta, apresentando aspectos histórico-culturais inerentes a ele. Reisseman (1993, p. 4), por exemplo, situa as narrativas como reveladoras da vida social, ou seja, uma história individual é um campo sobre a cultura na investigação social. Fabrício e Bastos (2009, p. 42) afirmam que "contar histórias parece ser, assim, uma forma privilegiada, em nossa cultura, de projeção de sentido para a experiência humana." Ainda segundo as autoras, "a forma narrativa seria, assim, uma forma de prática social estruturadora não só do discurso, mas também das relações sociais, constituindo-se em um mecanismo rotineiro de intelecção [...] sobre quem somos, sobre quem são os outros e sobre o que nós e eles fazemos" (FABRíCIO; BASTOS, 2009, p. 42). Rabelo (2011, p. 173) indica que "o que se transmite com as narrativas é o grupo de regras pragmáticas que constitui o vínculo social, encontrando a matéria desse vínculo não só na significação dos relatos, mas no próprio ato de sua narração". Do mesmo modo, a estrutura narrativa reflete os modelos socioculturais de interpretação de mundo (RABELO, 2011, p. 6).

A prática narrativa, vista como prática discursiva, tem ganhado força nas pesquisas de diversas áreas pela possibilidade de "compreensão da relação entre discurso, identidade e sociedade, pois as formas narrativas de (re)construção da experiência organizam nossas ações, nossa percepção de mundo e nossas 
ficções identitárias" (FABRÍCIO; BASTOS, 2009, p. 41-42). Nesta pesquisa, aponto nas análises alinhamentos das narrativas a discursos de senso comum. Conforme será visto na seção de análise, trabalhei não somente com as codas avaliativas, mas também, em conjunto com o arcabouço importado do Sistema de Avaliatividade, busquei elementos avaliativos que surgiram por meio dos itens presentes em toda a estrutura narrativa. Esses itens correspondem a intensificadores lexicais e avaliações encaixadas no fluxo da história. Conforme o próprio Labov (1972) diz, a avaliação se "espalha" por toda a narrativa e pode ocorrer de duas formas. A avaliação externa aparece ao longo do relato, quando o narrador interrompe sua história e comunica diretamente ao interlocutor o seu ponto de vista sobre o fato narrado. Já a avaliação encaixada é dada de forma indireta, por meio de recursos linguísticos gramaticais, semânticos e/ou prosódicos (entonação, alongamento de vogais, diferenças no andamento rítmico da fala, etc.), que funcionam como elementos avaliativos da narrativa (NÓBREGA, 2009, p. 79-80). A avaliação se constitui, assim, como categoria para as análises desta pesquisa.

Passo agora à discussão sobre elementos mais macrodiscursivos, que envolvem o que muitas vertentes de análise do discurso chamam de ideologia. Para a tese, o conjunto principal de elementos da ordem social a que farei referência serão os sistemas de coerência, conforme trago agora na seção que se segue.

\section{2. \\ Os sistemas de coerência das ordens sociais}

Já que trabalhei com narrativas, entendo como necessário o desenvolvimento da reflexão sobre a criação de coerência. Linde (1993) desenvolve sua teoria sobre coerência narrativa destacando sua estreita relação com a forma como se moldam as narrativas para que se tornem legítimas quando contadas. Esse modelamento das histórias contadas "se conformam" naturalmente às ordens sociais, conferindo coerência na ordenação dos eventos narrados. Para a autora,

[...] o processo narrativo em si é o foco da análise e os tipos de narrativas ou outras formas de discurso disponíveis em uma determinada cultura são enfatizados, uma vez que esses recursos hermenêuticos influenciam significativamente a emoção e 0 
comportamento compreensíveis em uma cultura (LINDE, 1993, p. 48, tradução nossa $)^{25}$.

É necessária a projeção de histórias coerentes e aceitáveis para que se possa existir no mundo social (LINDE, 1993, p. 3). Por isso, a coerência é também uma exigência pessoal, pois "a coerência que produzimos para o consumo social tem relação com nosso desejo individual de entender nossa vida como coerente, como fazendo sentido, história de uma pessoa adequada" (LINDE, 1993, p. 17). Essa adequação atende ao conjunto de descrições normativas de demanda social que preparam sobre o que se pode esperar que seja uma ação situada (BRUNER, 1997, p. 41). Ainda para Linde (1993, p. 16) "o processo de criação de coerência não é uma questão simples; é, de fato, uma obrigação social que deve ser cumprida para que os participantes apareçam como membros competentes da sua cultura".

Nesta pesquisa, considero as caracterizações sobre os "cotistas" e o modelo de hierarquização via meritocracia como parte de um sistema de coerência que circula na ordem social e se atualiza na escola em foco, constituindo-se em Discurso. Esses sistemas de coerência que se alinham ao senso comum serão considerados nas análises deste estudo. Eles sustentam uma estrutura de poder que a política de cotas abala. A coerência da meritocracia é por ela própria um entrelaçado de poder e mérito (BARBOSA, 2014), conforme o termo cunhado por si só indica, e entrega o espaço escolar público de qualidade a determinada parcela da sociedade que, em consonância com os ideários de sua defesa, não são os "cotistas", como se verá no capítulo de análise.

Com isso, encontro afinidade com a reflexão de Linde (1993, p. 18), quando ela diz que "embora a coerência de um texto resulte das condições de como o texto é criado e negociado, há também uma base cultural para qualquer negociação". E para essa base cultural e a negociação a ela inerente, as estruturas de poder do Discurso não podem ser negligenciadas, em especial por se tratar de uma política pública tão controversa como a política de cotas.

Esse conjunto de crenças compartilhado pela sociedade em uma cultura específica é o que se define aqui como senso comum e "seus pressupostos são tão óbvios e transparentes para os membros de uma cultura que eles têm dificuldade de percebê-los como tal" (LINDE, 1993, p. 18). O sistema de coerência

25 Tradução livre minha do texto original: "the narrative process itself is the focus of analysis, and the types of narratives or other discourse forms available in a given culture are emphasized, since these hermeneutic resources significantly influence understandable emotion and behavior in a culture" (LINDE, 1993, p. 48). 
da meritocracia, tomado nesta pesquisa como um sistema de senso comum, é pilar para a sustentação do viés liberal de economia e, por isso, já não mais é identificado pelos membros que o utilizam como discurso, mas como "verdades" na validação de seus argumentos.

Assim sendo, os ideais identificados nos discursos das narrativas desta pesquisa contribuem para a manutenção do Discurso meritocrático. Fairclough (2010, p. 26) diz que "as ideologias são um elemento significativo dos processos através dos quais as relações de poder são estabelecidas, mantidas, encenadas e transformadas". Tomemos esta pesquisa, então, como instrumento de entendimento de quais ideologias circulam nos discursos da escola e que consequências, em termos que construção discursiva macro, estão ocorrendo nessas estruturas de poder aparentemente enraizadas no CEFET/RJ.

Para entender melhor a formação discursiva que cerca os estigmas sobre cotas atualizados por esses discursos, na próxima seção falo sobre o conceito de estigma, conforme desenvolvido por Goffman (1988).

\section{3. \\ O Estigma por Goffman e os estigmas sobre cotas}

Assim como sobre as narrativas, meu contato com o conceito de Estigma, por Goffman (1988), também se deu pelas disciplinas durante o caminho de doutoramento. Mesmo antes de prestar o certame para o programa de doutorado em estudos da linguagem da PUC-Rio, eu sabia sobre qual tema queria desenvolver a pesquisa, o que obviamente coloquei em meu projeto de aplicação para a seleção. Eu entendia que havia rotulações oriundas de determinadas etiquetas direcionadas aos alunos que acessavam o CEFET/RJ pela política de cotas. Apenas não compreendia, ainda, que havia uma teorização que respondia ao que eu estava descrevendo em meu projeto. Goffman (1988) se encaixa de modo perfeito no que precisava para entender as construções sobre os alunos.

O autor oferece a descrição da linguagem como componente das situações sociais. Considero aqui, então, com base no conceito de estigma definido por Goffman (1988), o indivíduo estigmatizado como aquele que está ou é inabilitado para aceitação em diferentes situações sociais. Nesta pesquisa, o aluno "cotista" enfrenta resistências múltiplas para existir no espaço escolar, não só por ações 
cotidianas sofridas, mas pela linguagem, por meio do discurso. Por este motivo, entendo que o aluno é lido como inapto para aceitação social no espaço escolar.

Para dar corpo às definições que aqui abordarei, faz-se necessária uma breve explicação sobre o que seriam, segundo o autor, as noções de identidade social virtual e identidade social real. Constantemente, são projetadas sobre o outro expectativas normativas, o que se chama de identidade social virtual. Em contraponto, está a identidade social real, na qual se encontram as categorias e os atributos do indivíduo que se atualizam na interação (GOFFMAN, 1988, p. 12).

O estigma surge onde está presente alguma expectativa socialmente estabelecida que é quebrada, dando espaço para a tensão entre o atributo e o estereótipo. Surge um desequilíbrio entre o que se projeta e o que se atualiza na interação, formando-se o estigma a partir da imposição de um atributo depreciativo do sujeito. A posição que passa a ocupar na sociedade é a de não aceitação devido à informação social negativa sobre o indivíduo, seja de modo voluntário ou involuntário (BIAR, 2015, p. 117).

No presente estudo, a partir das práticas discursivas que observei, considero o aluno matriculado na instituição via política de cotas como estigmatizado, tendo em vista a identidade histórica de alunado branco e de classe média que antes prevalecia no CEFET/RJ. Conjecturo, também, que a quebra de expectativa normativa sobre o aluno negro e pobre traz uma série de perspectivas negativas sobre seus comportamentos e desempenho escolar. O estereótipo que acompanha o aluno "cotista" faz com que, nos encontros mistos ${ }^{26}$ de copresença, os envolvidos enfrentem diretamente as causas e efeitos do estigma (GOFFMAN, 1988, p. 23).

Há de se considerar, neste sentido, que "as identidades se manifestam em copresença a partir de sinais de várias naturezas que a todo tempo os participantes de interações cotidianas emitem e interpretam" (BIAR, 2015, p. 116). A partir desses sinais, a situação social é entendida e definida, orientando o modo como o indivíduo deverá agir.

Entendo que, quando Goffman (1988) teoriza sobre o estigma, há o objetivo central de descrever sobre o que ele chama de manipulação de identidade deteriorada, no âmbito interacional. A manipulação a que ele se refere não apenas dá nome ao seu livro, mas se refere também à manipulação das tensões geradas durante o contato social e a manipulação das informações sobre o que o deteriora (GOFFMAN, 1988, p. 51). A descrição dos comportamentos interacionais em

26 Goffman (1988) define encontro misto como a situação social de interação entre um indivíduo estigmatizado e outro não estigmatizado. 
encontros mistos serve de base neste estudo para as análises das narrativas dos docentes, de modo a auxiliar nas reflexões sobre os constituintes ideológicos macrossociais que se reproduzem e/ou se atualizam no momento interacional.

Considerando neste estudo, como já se disse, o aluno "cotista" como uma categorização dentre todos os alunos ("cotistas" e "não cotistas"), são esperados determinados atributos depreciativos para eles. Como é possível se ver nas análises do capítulo 5 , os posicionamentos sobre as cotas aparecem em forma de caracterizações sobre os alunos, muitas delas atendendo às expectativas de comportamento, aparência e histórias sobre os "cotistas". Resta entender se esses atributos são criados para manter internamente uma ordem macrossocial discursiva sobre o "cotista", se atualiza o Discurso de senso comum na sociedade sobre eles ou ambos.

\section{4. \\ O Sistema de Avaliatividade}

Já discorri sobre a estrutura narrativa e as relações sociais localizadas nas interações. Neste momento, é necessário explicar com que base teórico-analítica atendi aos objetivos deste trabalho, entre eles me debruçar sobre as avaliações nas narrativas. Conforme expliquei na seção metodológica, meu contato com o Sistema de Avaliatividade se deu após perceber uma grande carga avaliativa nas narrativas. A partir do momento em que identifiquei os numerosos itens de avaliação, fui em busca de encontrar a teoria que melhor atenderia à conceitualização desses elementos. Ao cursar a disciplina Linguística SistêmicoFuncional, durante minha trajetória acadêmica do doutoramento, encontrei o aporte conceitual que traria sustentação teórica para os itens de avaliação das narrativas dos docentes entrevistados em minha pesquisa. Nesse momento, então, percebi a grande afinidade entre a análise de narrativas e a avaliatividade.

Considero, como também já explicado no capítulo de metodologia, a possibilidade de entrelaçar teorias para auxiliar na análise das narrativas, de forma que possa ser ampliada a visão sobre questões de avaliação no discurso. $\mathrm{Na}$ seção 4.1 discorri sobre como as narrativas são (re)construções de experiências situadas no processo social dos significados. Volto atenção, então, às avaliações dentro de toda estrutura narrativa para entender como o estigma sobre o aluno "cotista" é (re)significado. 
Muitos autores discorrem sobre avaliação e pretendo aqui manter uma linha de suporte teórico baseada na abordagem sociolinguística das narrativas (LABOV, 1972; LINDE, 1993, 1997) junto ao elemento de coconstrução de avaliação neste tipo de interação, encontrado no Sistema de Avaliatividade (MARTIN; WHITE, 2005). A integração dessas teorias não é novidade na área de estudos da linguagem e foi desenvolvida por Nóbrega (2009), que encontrou pontos de contatos entre elas, entendendo que, apesar de terem propósitos em si diferentes, ambas têm como ponto em comum a avaliação como item de grande valor para as análises no campo da linguagem.

O contexto, neste estudo, é o ponto de partida para o encontro dessas duas teorias. A análise de narrativa, segundo Nóbrega (2009), tem o foco contextual e as suas funções sociais são ressaltadas de acordo com o contexto específico. O Sistema de Avaliatividade "também se baseia em aspectos sociais e funcionais para conduzir investigações acerca da prática avaliativa" (NÓBREGA, 2009, p. 78).

Ambas as teorias têm foco, também, na dimensão interpessoal da avaliação, conforme explica a autora. Nas narrativas, os papéis desempenhados por todos os participantes têm importância para as negociações de sentido que estão presentes na interação e no contexto da narrativa. Do mesmo modo, no Sistema de Avaliatividade, a avaliação é negociada entre o falante e o ouvinte, incluindo o próprio uso da linguagem na dinâmica interacional (NÓBREGA, 2009, p. 89). Lima (2014, p.133) resume que "é por meio da função interpessoal que são instanciadas as relações pessoais e sociais dos participantes dos eventos discursivos, tanto no aspecto de sua configuração identitária como da sua relação com os outros atores sociais envolvidos no processo".

Os recursos oferecidos pelo Sistema de Avaliatividade auxiliam no estudo das relações da linguagem com os temas sociais (MAGALHÃES; NÓBREGA, 2016, p. 335). Considera-se que, quando há posicionamento no discurso, é possível identificar as marcas de emoções, construções ideológicas e criação de significados nas interações sociais, entendendo a experiência de cada um no mundo social. Pelo Sistema de Avaliatividade (MARTIN; WHITE, 2005), a avaliação permeia toda a narrativa, não só no elemento de avaliação proposto por Labov (1972), mas está presente inteiramente na estrutura narrativa.

Nóbrega e Abreu (2015, p. 254) organizam a conceituação do Sistema de Avaliatividade localizando-a, primeiramente, sob uma perspectiva hallidayana (HALLIDAY, 1985), a qual este autor relaciona estrutura social e contexto à produção discursiva, e subdivide as manifestações do sistema linguístico em 
metafunções derivadas do contexto (LIMA, 2014, p. 132). O sistema de avaliatividade encontra-se inserido na metafunção interpessoal da linguagem e organiza-se em subsistemas inter-relacionados, conforme resumido no quadro a seguir:

Quadro 2: Organização visual resumida do Sistema de Avaliatividade.

\begin{tabular}{|c|c|c|c|}
\hline \multicolumn{4}{|c|}{ SISTEMA DE AVALIATIVIDADE } \\
\hline Subsistemas & & & \\
\hline \multirow{3}{*}{ ATITUDE } & \multirow{3}{*}{ 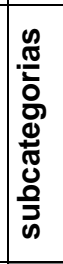 } & AFETO & \begin{tabular}{|c|} 
Recursos usados na \\
construção de emoções e \\
sentimentos
\end{tabular} \\
\hline & & JULGAMENTO & \begin{tabular}{c|} 
Avaliações de \\
comportamento humano
\end{tabular} \\
\hline & & APRECIAÇÃO & $\begin{array}{l}\text { Construção de valores de } \\
\text { coisas ou fenômenos }\end{array}$ \\
\hline ENGAJAMENTC & & & \\
\hline GRADAÇÃO & & & \\
\hline
\end{tabular}

Fonte: Elaborado pela autora a partir de Nóbrega e Abreu (2015, p. 254).

As subcategorias Afeto, Julgamento e Apreciação27 "se ligam por meio do afeto, uma vez que as emoções perpassam a prosódia do discurso em sua totalidade" (NÓBREGA; ABREU, 2015, p. 254). Para a pesquisa, foquei no eixo de análise da Atitude $^{28}$, com prevalência da subcategoria Julgamento, canalizando as análises na abordagem valorativa. Conforme explica White (2004, p. 177),

[...] a abordagem está interessada nas funções sociais desses recursos, não simplesmente como formas através das quais falantes/escritores individuais expressam seus sentimentos e posições, mas como meios que permitem que os indivíduos adotem posições de valor determinadas socialmente.

Seguindo por este caminho, a dimensão moral da avaliação também se constitui em um ponto de conexão entre as duas teorias que uni na análise. Segundo Nóbrega (2009, p. 89), o Sistema de Avaliatividade igualmente se preocupa em investigar, descrever e explicar as possíveis formas usadas por falantes/escritores com o objetivo de avaliar, adotar posicionamentos/posturas morais", entendendo a valoração como "um sistema da semântica do discurso" (MARTIN; WHITE, 2005, p. 25) e compreendida como "uso avaliativo da linguagem" (WHITE, 2009, p. 2 apud NÓBREGA, 2009, p. 89).

\footnotetext{
${ }^{27}$ As palavras referentes aos sistemas e subsistemas avaliativos são escritas com letras maiúsculas, conforme os fundamentos do Sistema de Avaliatividade (NÓBREGA, 2009, p. 87), os quais acompanho neste estudo, mantendo a proposição.

${ }^{28}$ Por questões de delimitação de escopo nas camadas de análise e devido à pouca recorrência nos dados, os subsistemas de Engajamento e Gradação não foram considerados.
} 
Neste momento, detalho rapidamente as subcategorias do sistema da Atitude, por meio do qual os participantes avaliam positiva ou negativamente os contextos (LIMA, 2014, p. 134). Primeiramente, abordo o Afeto, que aponta as reações afetivas do narrador na situação e por meio do qual lida com os recursos utilizados para o entendimento e construção de emoções individuais. No domínio do Afeto, o narrador é indicado a como se orientar emocionalmente à situação ou ao contexto (NÓBREGA, 2009, p. 95).

O subsistema Julgamento refere-se a elementos de avaliação de comportamentos e, por isso, relaciona-se a questões éticas (LIMA, 2014, p. 134). As categorias do Julgamento remetem ao posicionamento moral do narrador, que são avaliados de acordo com a cultura, crenças e ideologias em determinado contexto e, geralmente, são baseados nas experiências pessoais dele, relacionando-se à estima social (quebra de expectativas) ou à sanção social (repreensão pública) (NÓBREGA, 2009, p. 97; BORGES, 2017, p. 65).

Essas duas subdivisões do Julgamento vêm de diferentes representações e comunidades discursivas. A estima social são valores que "integram o processo mais básico de integração social e são regulados por meio, dentre outros, da cultura oral, estando mais estreitamente ligados a comportamentos passíveis de admiração, estranhamento, menosprezo ou reconhecimento" (LIMA, 2014, p. 138). A sanção social relaciona-se a avaliações codificadas pela cultura, e seus valores ligam-se "às obrigações morais e éticas, à cidadania e à filiação institucional. Por essas razões, os julgamentos de sanção social implicam atitudes não de admiração ou estranhamento, mas de louvor/destaque ou condenação/recriminação" (LIMA, 2014, p. 138).

Por fim, o subsistema Apreciação remete à preocupação estética (LIMA, 2014, p. 134) e performances e não faz referência à avaliação de comportamentos humanos. A estrutura da Apreciação inclui expressões de preferência e não preferência e tendem a encaixar-se em itens de processos cognitivos mentais ("eu acho", "penso", "acredito que") (EGGINS; SLADE, 1997, p. 126 apud NÓBREGA, 2009, p. 98).

Com essa abordagem, pretendo instrumentalizar de forma sistemática o modo como as avaliações e as posições de valor se alinham ou se distanciam de determinadas "comunidades de interesse associadas ao contexto" (WHITE, 2004, p. 177). Para além da estrutura lexicogramatical, o Sistema de Avaliatividade auxiliará, nas análises, o exame de todos os elementos avaliativos presentes na narrativa. A percepção desses elementos ocorre com o entendimento do sistema de crenças e significados, com a percepção da interação de múltiplos elementos 
em um enunciado (NÓBREGA, 2009, p. 94), com a localização de posicionamentos morais e com os aspectos prosódicos que definem itens de avaliação.

\section{5. \\ Estratégias retóricas a partir de Wodak et al.}

Ainda em um momento embrionário do desenvolvimento da tese, mas já com a pesquisa em andamento e com as primeiras narrativas-piloto analisadas, no momento da qualificação do meu doutoramento, estava presente na banca de avaliação o Professor Doutor Georg Wink, da Universidade de Copenhague. O convite para que o professor viesse ao Brasil para participar da banca de qualificação se deu pelo doutoramento sanduíche que estava prestes a realizar, por sete meses, sob sua orientação e supervisão, na referida universidade, na Dinamarca.

Neste momento de avaliação realizado pela banca de qualificação, dentre os diversos encaminhamentos sugeridos pelos membros, o professor atentou para o fato de que era necessário encontrar um modelo a ser seguido que capturasse melhor a retórica dos docentes entrevistados em minha pesquisa. Indicou que era necessário considerar os macrodiscursos aos quais as pessoas fazem referência e descobrir nas falas dos docentes o que se repete. Quais grandes tópicos ou quase citações aparecem e indicam o que ele chama de "grandes narrativas" que circulam no Brasil. Seria necessário identificar, por meio de ferramentas refinadas de análise, o poder persuasivo do discurso pelas estratégias retóricas, e constatar a existência do estigma por esse caminho.

Sendo assim, segui para meu doutoramento sanduíche na Universidade de Copenhague com a tarefa de encontrar não somente material de análise externa (dos países desenvolvidos) sobre as políticas afirmativas no Brasil, mas também para desenvolver uma análise mais apurada dos meus dados. O professor Georg, então, após um trabalho detalhado de leitura e supervisão sobre meus dados, indicou uma opção de caminho pelo modelo de retórica desenvolvido por Wodak et al. (2009).

Para iniciar a discussão e reflexão sobre o modelo que Wodak et al. (2009) propõem, trago aqui o próprio professor Wink (2018) para desenvolver melhor os pressupostos da Análise Crítica do Discurso. Vale ressaltar que esta tese não tem 
como ferramenta de análise central a ACD, mas posso dizer que bebo, bastante, dessa água para ter mais perspectiva crítica sobre as entrevistas, através exatamente do modelo proposto por Wodak et al. (2009).

Segundo Wink (2018), as políticas afirmativas no Brasil não reduziram a qualidade da educação, mas, ainda assim, não mudaram a posição negativa da sociedade sobre as cotas. Dessa forma, faz-se necessário e premente lançar olhar sobre a retórica e as estratégias retóricas utilizadas nos argumentos contra cotas. O que Wink (2018) traz à reflexão é que, mesmo com os dados apontando para o avanço positivo dos resultados, os argumentos anticotas ainda parecem sobreviver aos "hard facts" (WINK, 2018, p. 5). No caso do CEFET/RJ, mesmo ao final de um ciclo inteiro de formação, entendendo que os alunos, por meio das políticas de permanência, chegaram até o final para uma formação com menor evasão escolar, ainda são reproduzidos tópicos que deslegitimam a política de cotas como exitosa ou necessária.

Assim, Wink (2018, p. 6) lança a reflexão sobre o porquê dos argumentos anticotas serem tão poderosos, ainda. Por isso, é preciso ir além do enunciado e da sua mera repetição (WINK, 2018, p. 6), voltando o olhar para "como" eles argumentam, e não somente o que e onde argumentam.

Na próxima seção, desenvolvo a reflexão sobre os grandes Discursos, como o do esforço individualizado recompensado, que se sustentam na sociedade brasileira mediante narrativas mantidas pelo sistema de coerência da meritocracia. Por ora, trabalho agora na mesma direção, mas em sentidos opostos para entender como as narrativas-mãe ${ }^{29}$ da identidade nacional brasileira legitimam os argumentos presentes em estratégias retóricas específicas das narrativas dos docentes (WINK, 2018, p. 7).

O autor incorpora conceitos-chave de Foucault e sua concepção sobre discurso, partindo da ideia de que o discurso em si determina como uma posição crítica torna-se representação de um processo discursivo macro. A metodologia que Wink (2018) utiliza e que ofereceu como ferramenta na orientação desta pesquisa vem da ACD e pensa na complexidade dos discursos, com a sua fluidez e capacidade de produzir coerência através do que ele chama de coleções de símbolos persuasivos, como estereótipos ou "topoi”. Essa coleção de símbolos é acionada como catacreses, que Wink $(2018$, p.8) define como "conexão arbitrária

${ }^{29}$ Master-narratives (WINK, 2018, p.7). 
de uma questão complexa com uma imagem simples e coerente, mesmo que não tenha relação temática, que reforça o poder do discurso"30.

Para essa análise mais apurada e criticamente posicionada, Wink (2018) e eu utilizamos, então, as estratégias de Wodak et al. (2018). Os autores, também da linha da Análise Crítica do Discurso, entendem que os atos discursivos são constituídos socialmente de diversas maneiras. Para entender o discurso como prática social, é preciso entender que os atos discursivos são, primeiramente, responsáveis pela produção e criação de condições sociais. Depois, eles contribuem com a restauração, legitimação ou relativização de determinado status quo. Os atos discursivos são também utilizados para manter e reproduzir este status quo e, por fim, podem ser efetivos em transformar, desmantelar e até destruí-lo (WODAK et al., 2009, p. 8).

A partir desses entendimentos e delimitações dos atos discursivos, que os autores afirmam apresentarem "macrofunções sociais", eles organizam e distinguem, então, estratégias retóricas voltadas ao seu trabalho (WODAK et al., 2009). Para o estudo em questão, eles trabalham com estratégias retóricas macrodiscursivas que montam os discursos sobre refugiados. Para a minha pesquisa, os termos que Wodak et al. (2009) criam não atendem exatamente às narrativas da minha tese, cujos discursos têm recursos mais sutis de fala, que serão apreendidos e analisados através dos itens de avaliação. Por esse motivo, adaptei os termos dos autores, criando novas nomenclaturas que atendem, enfim, às características retóricas do discurso dos docentes em minhas entrevistas. No quadro 3, exponho a nova terminologia criada por mim e adaptada do modelo de Wodak et al. (2009).

\footnotetext{
${ }^{30}$ Tradução livre minha do texto original: the arbitrary connection of a complex issue with a simple and coherent, yet thematically unrelated image in the sense of Link, which reinforce the power of discourse (WINK, 2018, p. 8).
} 
Quadro 3: Terminologias adaptadas de estratégias discursivas segundo Wodak et al. (2009).

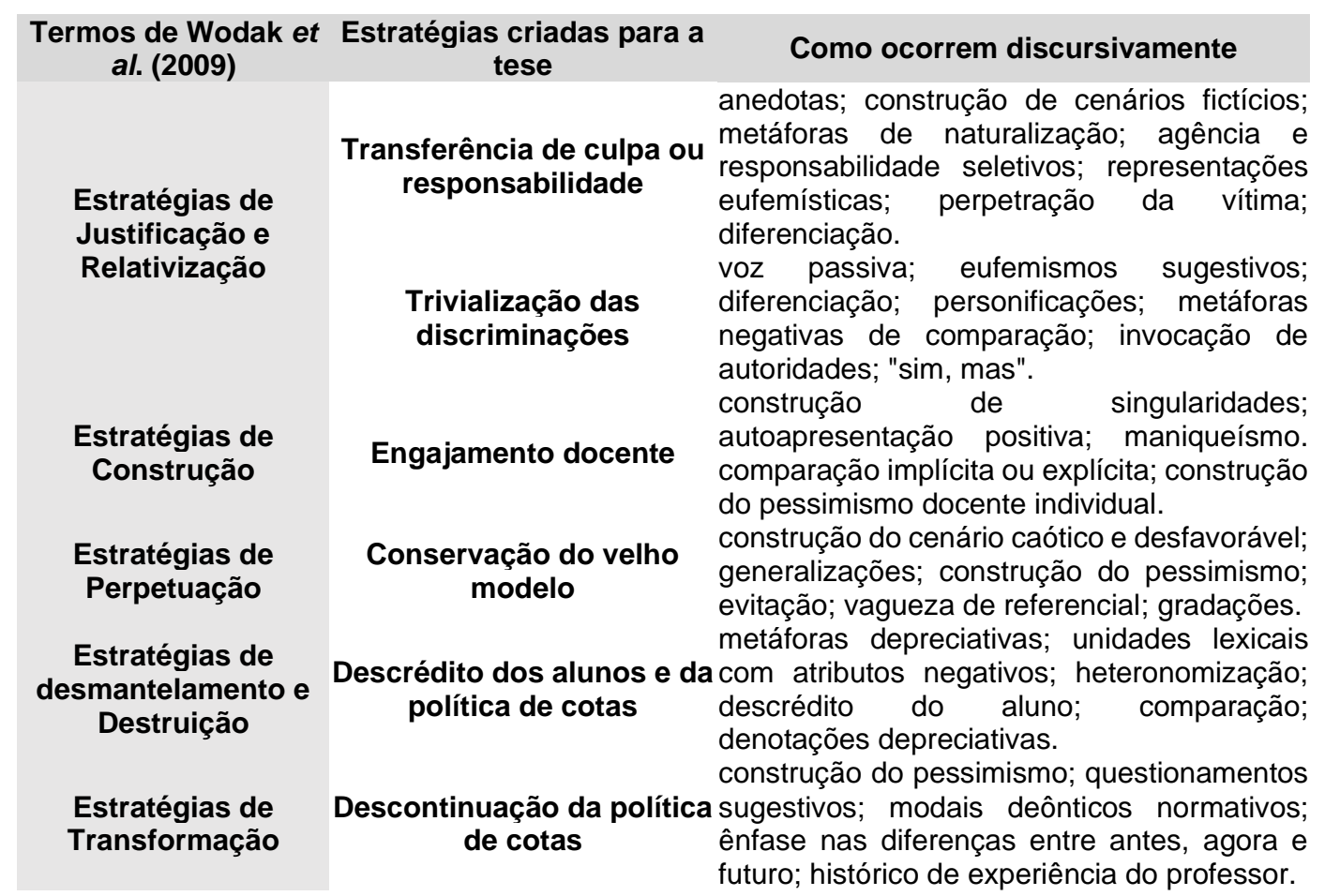

Fonte: Adaptado pela autora de Wodak et al. (2009).

Em um nível macro, então, Wodak et al. (2009) distinguem entre diferentes tipos de macroestratégias aplicadas na formação discursiva de sua pesquisa (WODAK et al., 2009, p. 33), instrumentalizando o que os autores definem como o objetivo da ACD que é "desmascarar as obscuras estruturas de poder, controle político e dominância, que servem como estratégias de inclusão e exclusão discriminatórias no uso da linguagem" (WODAK et al., 2009, p. 8).

Por fim, este modelo foi a opção metodológica que escolhi para lançar o olhar crítico sugerido no exame de qualificação pelos professores doutores presentes e, assim, apurar a construção discursiva dos estigmas em meus dados, seguindo os seguintes passos:

1. localizar a dimensão retórica do discurso nas narrativas dos docentes;

2. entender qual a função que a retórica ocupa na posição da estratégia para emitir uma opinião;

3. identificar especificamente as estratégias discursivas retóricas;

4. identificar e entender à qual argumentação macrossocial as estratégias se ligam. 
Adiante, na próxima seção, então, farei algumas reflexões sobre a meritocracia e as ideias em relação dialógica com esse Discurso.

\section{6. \\ A Meritocracia e a manutenção de uma poderosa ordem social}

Para nortear inicialmente a discussão sobre a meritocracia, a qual chamarei aqui de sistema de coerência de senso comum da meritocracia, sinto ser necessário me explicar sobre a fusão entre diferentes definições de discurso que farei. Dentre diversificadas linhas de concepções sobre discurso às quais somos expostos nos Estudos da Linguagem, dois autores me chamam a atenção pela minha incapacidade de "separá-los" em teorias diferenciadas: Bakhtin e Foucault. Ao longo do meu doutoramento, procurei trabalhar com essas duas definições de discurso de forma complementar. Resumindo aqui, Bakhtin explica o discurso como a língua em uso, enquanto Foucault o define como prática social centrada na linguagem. Portanto, basicamente a definição geral de discurso que utilizo para esta pesquisa é a da língua em uso em práticas sociais construídas, guiadas, modificadas e transformadas pela linguagem.

Ambos os autores trazem à tona a noção de ideologia em suas teorizações originais. Permitam-me aqui, dentre tantas permissões que peço para elucidar minhas reflexões "cruzadas", explicar que utilizarei o termo "ideologia" como sinônimo conceitual dos sistemas de coerência. Como nesta seção exponho as ideias de Bakhtin e Foucault sobre discurso, e ambos utilizam o termo "ideologia", serei fiel às teorias originais neste momento.

Antes de mergulhar no tema da meritocracia, é preciso entender algumas definições gerais sobre Discurso. Retomando Bakhtin (2003), a relação entre significado e significante é histórica e ideológica, sendo o significado uma arena de disputa. As palavras significam coisas diferentes, dependendo de quem fala, quem escuta, das posições onde quem fala ou escuta se encontra e dos momentos históricos. Nesse sentido, o significado "dança" conforme as posições ideológicas. Por isso, quando se fala de mérito, entra-se em uma arena de embates ideológicos diversos.

No contexto do CEFET/RJ, por exemplo, os diversos discursos estigmatizantes sobre os alunos compõem uma cadeia de enunciados dialógica. Todo o enunciado está intimamente relacionado com outros enunciados que o 
precederam e o sucederam. Dentro da escola, cada enunciado sobre cotas emitido forma um elo em uma corrente de comunicação e, assim, constrói sentidos específicos sobre as cotas.

Trazendo Goffman (1986) para esta discussão, encontro um caminho para entender em minha pesquisa, então, de que forma os enunciados constroem, transformam ou acentuam o poder do Discurso sobre cotas no CEFET/RJ. O enunciado está localizado em uma ordem social (macro) e em ordem(ns) interacional(is) (micro). A relação entre essas duas ordens é indexical. Essa ordem macro tem a ver com a história, com a ideologia e com contexto sociocultural. A ordem "micro" tem a ver com os cenários concretos de comunicação. Toda vez que se utiliza a linguagem, ela é contextualizada nestas duas esferas: ordem social e interacional.

Para Bakhtin (2003), essas duas ordens nunca estiveram separadas. O que garante essa costura é o gênero do discurso em questão, que é sempre local e situado interacionalmente e sem deixar de ser uma forma de organização social da linguagem em uso, para além da interação entre dois ou mais sujeitos em copresença, uma vez que esses enunciados são sempre dialógicos e atravessados por outros discursos.

Goffman (1986) chama a atenção para a necessidade de se olhar a ordem interacional, entendendo que, ao fazermos coisas juntas e interagirmos, construímos uma ordem macro. Pela gramática chamada de tradicional, palavras indexicais - como "isso" - em si mesmas não possuem significado. Elas ganham sentido quando estamos em uma relação completa de interação que depende de certo apontamento que se realiza dentro de um cenário de situação específica. $A$ indexicalidade, segundo Melo e Lopes (2015, p. 61), é

\footnotetext{
[...] embasada no viés foucaultiano de ordem do discurso compreendida, segundo Blommaert $(2006,2010)$, como procedimentos impostos ou por qualquer sociedade ou pelo próprio discurso, que controlam as produções discursivas, ora fazendo emergir alguns discursos, ora outros, relacionando-se aos valores normatizados, hierarquizados, estratificados e apontados no processo de indexicalização de Discursos.
}

Os autores trazem a voz de Blommaert (2010) para explicar que as ordens de indexicalidade são segmentadas e hierarquizadas para expor a relação de poder que existem nelas (MELO; LOPES, 2015, p. 62). Então, indexicalidade, por si, é apontar para uma coisa que é externa a ela mesma. O discurso é indexical porque aponta para uma ordem histórica e ideológica. O que fazemos com a análise do discurso interacional, como farei nesta tese, é tentar mostrar essa 
relação entre o uso específico da linguagem e as relações sociais, históricas e de poder, e como estão conectados com esse uso, considerando que o poder tem uma natureza discursiva (FOUCAULT, 1996).

Assim, podemos pensar sobre que ações na vida social o discurso está realizando. Quais são os embates presentes nas palavras e nos discursos sobre a meritocracia e a quais lastros históricos eles estão relacionados? Dessa forma, também devemos pensar quais são as posições que estão em embate. Nesta tese, conforme explicitarei mais à frente, mostrarei como essas relações dialógicas se dão nas entrevistas com os docentes. É nesse ponto em que a diferenciação proposta por Goffman (1986) entre ordem social e ordem interacional será útil: auxiliará a análise do ponto de vista mais concreto de como o discurso foi enunciado e gerado e, também, de onde ele vem em termos históricos e sociais mais amplos. Mais adiante, no capítulo de análise, será possível entender como estabeleci a relação entre essas duas ordens (GOFFMAN, 1986).

Mas convoco aqui o retorno à reflexão sobre o poder do discurso, em especial, o poder fundado pelo discurso (FOUCAULT, 1996). Considerando que a ideologia da Meritocracia tem suas raízes bem fixadas e estabelecidas por sujeitos e instituições que, obviamente, ocupam lugares de poder(es) para fixar esse discurso como base de sucesso na sociedade brasileira, pensemos em como a questão do mérito é criada e mantida por esses sujeitos. Estar dentro de uma ordem do discurso é pura e simplesmente deter o poder. Sendo assim, tudo que deriva dessa detenção também é poder: entender o discurso é poder, produzir mais discursos é poder, refutar outros discursos é poder.

O ideal contemporâneo da meritocracia, após muitas mudanças de sentido ao longo do tempo, aponta para como a sociedade deve ser organizada (LITTLER, 2018). Ou seja, "a meritocracia é o principal meio cultural de legitimação da cultura neoliberal contemporânea - e que, embora prometa oportunidades, na verdade cria novas formas de divisão social" (LITTLER, 2018, prefácio). É não só um tema cujo significado se modifica ao longo do tempo, mas um tópico sobre o qual todos possuem alguma opinião sobre. E, sendo assim, transforma-se em argumento que sustenta outras ideologias, posições e divisões de poder na sociedade (LITTLER, 2018).

Quando voltamos o olhar para uma instituição como o CEFET/RJ, em que a assimetria é tão bem delimitada pelas próprias estruturas institucionais, fica evidente quais são as margens que o poder do discurso delimita. Fazendo uma analogia, imagino a grande piscina que o CEFET/RJ possui para atividades de 
Educação Física. Grande e cheia, aparentemente limpa ${ }^{31}$, representa o Discurso sobre o mérito para o sucesso acadêmico dentro da instituição. Ele está ali, fixo, dentro de limites que as bordas da piscina impõem, sem possibilidades reais de mobilidade para a mudança de seu estado estanque. Agora, imagine uma cerca de arame farpado sendo instalada no entorno da piscina e alunos em volta que desejam muito pular para dentro dela, espalhar a água, renovar, talvez até trocar aquela água toda que só está limpa aparentemente, pois não sabemos a sua qualidade real além do que está ali.

Os alunos que cito representam o contradiscurso que pode abalar a ideologia do mérito. O contradiscurso, aparentemente, não pode entrar em algo que já está bem estabelecido e protegido na instituição. Pode transbordar, pode dar um trabalho hercúleo ter que trocar toda aquela água da piscina, mesmo que isso sirva de melhores caminhos para novos nadadores. Não separo aqui, como lados opostos e conflitantes, alunos versus professores. Nem sequer sei se os alunos que figuram minha analogia são somente os que acessaram a escola pela política de cotas. Mas enxergo dessa forma a resistência do contradiscurso sobre o mérito dentro do CEFET/RJ. Algo que exige, e exigirá, muita luta para que comece a ser aceito e exista alguma possibilidade de renovação de toda esta água.

O pensamento meritocrático vem formando bases para a reprodução da cultura neoliberal, alimentando a plutocracia e tornando a própria palavra "meritocracia" um termo-chave, essencial para a reprodução dessa cultura (LITTLER, 2018, p. 2). Considerando o sistema econômico neoliberal contemporâneo como alicerce de comportamentos sociais, entendo haver a criação, nesse sistema, do ideal de que a meritocracia seja necessária para a manutenção econômica "saudável" do país, conforme a cultura do mérito concebe. E, como sabemos, a economia neoliberal é guiada por grandes poderes empresariais que não apenas operam sobre recursos financeiros base do nosso país, mas controlam todas as relações de poder relacionadas ao trabalho, à educação e às estruturas sociais, de modo geral.

Vale lembrar que o CEFET/RJ é uma instituição centenária que possui fundações ideológicas balizadas pelas mentalidades de grandes empresas.

31 Uma pequena curiosidade: Pelo menos uma vez ao ano, a piscina do CEFET/RJ fica completamente verde, como se fosse um pântano. Segundo a prefeitura interna do campus, é colocado um produto químico para a limpeza da piscina, que deixa esta coloração antes da água ser purificada. Existem nas redes sociais diversas brincadeiras sobre isso, incluindo o próprio termo "pântano". Não à toa, essa analogia me vem à cabeça para representar o discurso e o contradiscurso sobre meritocracia e cotas. 
Dessa forma, alguns sistemas de coerência (LINDE, 1993), incluindo os de ideais empresariais, como o empreendedorismo, a competição, o ranqueamento e o esforço individual, tiveram muitos anos para formarem terreno nesta escola. Não somente a política de cotas chega em 2012 no CEFET/RJ para abalar essa estrutura, como também a modificação curricular para a modalidade integrada encontra barreiras pela comunidade escolar, devido ao caráter de formação para o mundo do trabalho (SAVIANI, 1994), e não somente ao trabalho.

Segundo Littler (2018, p. 2), a meritocracia introjeta a ideia de que o resultado do esforço proporciona melhorias na qualidade de vida. Ela cita que:

\begin{abstract}
[...] fomos encorajados a acreditar que, se nos esforçarmos o suficiente, podemos chegar lá: que raça, classe ou gênero não são, em um nível fundamental, barreiras significativas para o sucesso. Para liberar nosso talento interno, precisamos trabalhar duro e comercializar-nos da maneira certa para alcançar o sucesso (LITTLER, 2018, p. 2).
\end{abstract}

No caso específico do CEFET/RJ, eu não poderia encontrar melhor palavra que descreva a característica de formação esperada por grande parte da comunidade escolar, que é exatamente a ideia de "comercializar" os alunos e o currículo de modo que atenda às especificações do mercado. A meritocracia torna-se, a partir dessa ideia, um princípio organizador problemático, que encaminha a sociedade a novas desigualdades assimétricas e a novas formas de estratificação social (LITTLER, 2018, p. 35).

Subir a escada rumo a determinado sucesso pelo mérito é uma ideia que estrutura a concepção do individualismo, tendo em vista que o sujeito sobe a escada sozinho e por suas aptidões vocacionais (LITTER, 2018, p. 3). Obviamente, não leva em consideração toda gama de oportunidades que cercam o sujeito que consegue escalar a escada até o topo. Littler (2018, p. 24) aponta para o contraste e o abismo existente entre a elite dos governantes e o sistema de acesso a essa elite, supostamente aberto. A autora desenvolve a ideia de que

\footnotetext{
[...] a meritocracia é um sistema estruturado em torno do avanço de pessoas selecionadas com base na conquista individual; e, como mostro ao longo deste livro, sua ênfase no indivíduo é importante. A "ocracia" da "meritocracia" deriva da palavra grega para governo e, como ilustra essa definição, a palavra pode com modificações ("meritocrat") se referir a um grupo de elite de pessoas que governam e que conseguiram chegar nessa posição "com base na capacidade ou conquista individual" (LITTLER, 2018, p. 24).
}

E é exatamente nessa lacuna que mora a imagem do sujeito que deve subir a escada do sucesso. A meritocracia é trabalhada pela autora como um sistema social em que os sujeitos são selecionados a partir de estruturas cujos requisitos 
não são especificados (LITTLER, 2018, p. 24), bem como não há transparência sobre que fonte seleciona ou tem o poder de selecionar os sujeitos que "vencem".

Seguindo ainda a conceitualização histórica do termo por Littler (2018), trago para a reflexão a ideia contemporânea de que a meritocracia endossa a competitividade em um sistema hierárquico linear (LITTLER, 2018, p. 3). A consequência desse sistema é a obviedade de que determinados grupos, principalmente os minoritários, ficarão de fora da oportunidade de "chegar ao topo", devido, principalmente, às interseccionalidades desses grupos. Essas interseccionalidades são ignoradas no sistema meritocrático, tendo em vista que o que é levado em conta é especificamente o mérito pelo esforço individual de determinado ponto relacionado ao sucesso da escalada.

No caso do CEFET/RJ, e nos sistemas escolares, o topo da escada talvez seja a formação e conclusão do curso. Mas é possível entender que o sucesso do topo também está relacionado ao quanto de esforço foi aplicado àquela realidade para que o aluno se formasse. Vale refletir sobre os julgamentos sobre o "cotista" que, por exemplo, repetiu cada ano uma vez e se formou no dobro do tempo esperado (caso hipotético). Será que esse serviria de narrativa para ser contada quando se pergunta sobre as cotas nas escolas? Ou somente servem as histórias sobre um esforço árduo para transpassar barreiras intransponíveis, com metáforas de superação que beiram o imaginário fantasioso de absurdos depreciativos?

Ainda segundo Littler (2018, p. 10), "Discurso" significa um conjunto de significados compartilhados em uma "formação discursiva" historicamente específica, e pode ser transmitida através de instituições, imagens e comportamento, além da linguagem". Assim, é possível dizer que o sentido de meritocracia como discurso ideológico é construído em cada contexto específico (LITTLER, 2018). Para Foucault (1996), a produção de discurso é organizada, selecionada, controlada e distribuída por quem domina. Há mecanismos de controle operando sobre o discurso. Há também procedimentos de exclusão de discursos (FOUCAULT, 1996).

Aqui resumindo, o autor diz que os princípios externos de controle do discurso são os mecanismos de interdição, que abarcam as coisas sobre as quais não se falam, coisas que só podem ser ditas em determinados locais e coisas que só determinadas pessoas podem dizer, e os mecanismos de separação e rejeição, que são classificatórios. A partir desse último, um discurso é separado para descartar outro (por exemplo: razão e loucura, verdadeiro e falso) e isso inclui a ideia de que saber é poder, em referência à história da ciência. Já os princípios 
internos de controle trazem o discurso indisciplinar que impõe condições de funcionamento e regras, selecionando os sujeitos que falam. Esses mecanismos são a própria natureza do discurso de se preservar e se perpetuar, delimitando zonas discursivas irrestritas e zonas impenetráveis e proibidas (FOUCAULT, 1996).

Com essas definições de Foucault (1996), entendo que as narrativas maiores que são contadas, repetidas e modificadas dão uma espécie de suporte de sustentação para os discursos que estão na origem, ou seja, aqueles que são ditos, permanecem ditos e estão por dizer, e os que se repetem, quais sejam, os novos atos de fala. Esses discursos dizem além do acontecimento, mas dizem também o acontecimento. Littler (2018, p.10) traz em seu livro a descrição dos discursos que ela chama de narrativas neoliberais de justiça. A autora questiona, então, exatamente a questão sobre quem detém o poder do discurso, em movimento parecido com a provocação que faço acima, quando trouxe Foucault (1996) para a discussão.

A autora conduz à reflexão sobre os problemas, aos quais a meritocracia está ligada:

\footnotetext{
[...]a questão de quem governa a sociedade, a questão de um pequeno grupo influenciar muitos, a competitividade em geral e a educação em particular, o espinhoso problema do que significa ter "mérito" e a promessa (e, menos conspicuamente, as armadilhas) da mobilidade social (LITTLER, 2018, p. 24).
}

Trazendo uma reflexão mais direcionada sobre a meritocracia, entendo que exista uma grande narrativa abstrata que se atualiza cada vez que contamos uma história de "sucesso" de alguém que beirava o "fracasso". As narrativas pontuais e particularizadas comentam essa grande narrativa abstrata que vai se repetir em diversas narrativas midiáticas a que assistimos. Tais histórias reforçam o sucesso como recompensa de esforço e trabalho repetitivo, por exemplo. Essa ideia central está em muitos discursos concretos que fazem referência a uma narrativa original que paira sobre as histórias particularizadas. Para Littler (2018, p. 51), as narrativas neoliberais de justiça "tentam corrigir algumas formas de desigualdade enquanto perpetuam outras".

Mais uma vez relaciono essa reflexão ao CEFET/RJ, entendendo que cada história de sucesso contada e recontada nos diversificados espaços da escola infunde nas mentes dos alunos, e também dos docentes, a ideologia do mérito. Circula, assim, a ideia de que "apenas" é preciso que todos se esforcem para alcançar as exigências já estabelecidas nesta escola há mais de um século. Aqui 
trabalho com o isolamento do mérito às demais variáveis que interseccionam os alunos, como a própria ideologia da meritocracia segue.

A ideia que apresentei acima sobre a subida na escada desconsidera as interseccionalidades que atravessam os sujeitos, de modo que a definição de sucesso fica estrita ao mérito pelo seu esforço. Para Littler (2018, p. 31), as histórias com a metáfora da escada foram delineadas "para popularizar a meritocracia neoliberal, para promover maneiras estratificadas, individualistas e competitivas de organizar o mundo no interesse de poucos". Novamente, vamos ao encontro das estruturas de poder alimentadas pelos discursos e, de modo cíclico, originadas do próprio poder.

A meritocracia cresce no espaço da sociedade que fica entre os que obtêm o melhor e quase tudo e os que obtêm menos ou nada (LITTLER, 2018, p. 32). Para a autora, os inteligentes, proativos e ambiciosos são "ajudados em direção às posições de domínio que lhes são destinadas" (LITTLER, 2018, p. 32). Como os "talentosos" usufruem dos resultados de seus esforços, colhendo as recompensas excessivas da sociedade, por contraposição, os demais sofrem o não recebimento devido a esse "acúmulo" entregue ao "talentoso" (LITTLER, 2018, p. 33). Essa é a lógica da meritocracia conforme significada ${ }^{32}$ no sistema neoliberal econômico e político.

Os docentes do CEFET/RJ também vivem o discurso do mérito, ajudando a construir esse ideal e se alinhando ou não a ele. O esforço passa a ser intimado como ideologia dominante da escola. Até aí, o discurso em si é construtivo de um sistema de coerência que estabelece e estrutura a identidade institucional do CEFET/RJ, o que não deixa de ser um problema. Mas problema maior é o desmembramento desse Discurso nas mentes de cada aluno que passa a se exigir e ser exigido com o fator único do mérito, esquecendo quantas mais variáveis ele mesmo possui em sua caminhada acadêmica e de vida. É o que vejo no dia a dia, os esforços exaustivos, a corrida por algo que nem eles mesmos acreditam que possam ultrapassar ou conseguir. É, talvez, o medo de não fazer parte da narrativa isolada e particular de sucesso após ter "dado o sangue" (como aparece em algumas narrativas das entrevistas dos docentes).

De que terá valido à pena todo o esforço se, após "fracassar", os alunos apenas terão servido de material para reforçar a experiência não exitosa da

${ }^{32}$ Vale ressaltar que Jo Littler (2018) traz outras definições sobre meritocracia em seu livro, conceitualizadas a partir de outros modos de economia. Segundo a autora, a definição de meritocracia varia de acordo com o contexto em que se insere. Aqui, para esta tese, de forma crítica, tomo por base a conceitualização da ideologia dentro do sistema neoliberal de economia política. 
política de cotas? Sugiro pensar nisso, então, como um enorme e emergente dilema. O discurso que se remodelará, a partir de novas referências narrativas, é fruto de uma política de cotas que tinha tudo para dar errado ou foram simplesmente geradas para que a política desse errado? Littler (2018, p. 50) desenvolve a ideia de que

[...] a meritocracia, em sua forma neoliberal, tende a endossar um sistema competitivo e linear de mobilidade social e a funcionar como um mito ideológico para obscurecer as desigualdades, incluindo o papel que esse discurso da meritocracia desempenha na verdade para restringir a mobilidade social. Seu mito da mobilidade é usado para criar a ideia de condições equitativas que não existem.

Aglutinando as duas ideias em uma única reflexão, a perpetuação do Discurso contra as cotas, que é apresentado pelas bases ideológicas neoliberais, atende a determinada necessidade de manutenção da ideologia da meritocracia. A quais objetivos obscuros o dominante está atendendo para que sejam gerados tantos discursos não exitosos para reforçar que a política não presta? Para que ou para quem é necessário que este Discurso tenha a manutenção em dia? Por que criar o cenário idealizado de que há condições equitativas reais na sociedade que atendem de forma suficiente às minorias?

Desconfiada de que todos já saibamos as respostas, a reflexão não é apenas para o CEFET/RJ, mas para a sociedade brasileira como um todo. Não apenas para as escolas de Ensino Básico que hoje atendem à política de cotas (CEFETs e IFFs), mas também às Universidades que ainda lutam pelo acesso mais democrático dos alunos e permanência deles diante da cultura de meritocracia. Não só a meritocracia de acesso às instituições, mas a de permanência nelas, já que são reforçados e até criados mais mecanismos de exclusão e expulsão de alunos que não acompanham exigências cada vez mais seletivas. A quem interessa todo o trabalho oculto de dificultar a ampliação de uma boa formação para toda a sociedade?

$\mathrm{Na}$ próxima seção, indico os encaminhamentos que proponho com esta tese, frente à metodologia proposta e junto aos conceitos aqui apresentados e desenvolvidos. 


\section{7. Encaminhamentos}

A discussão teórica que apresentei neste capítulo desenvolveu de forma articulada diferentes vertentes teóricas. Essa convergência de teorias se relaciona à tese da seguinte maneira:

1. Labov (1972) esquematizou a estrutura narrativa de modo a observar a organização das experiências pessoais de forma situada no espaço e tempo. $\mathrm{Na}$ análise aqui empreendida, lanço olhar para a estrutura da narrativa, para as sequências e a relação entre os eventos. A partir disso, esta pesquisa trará possibilidades de focarmos nas construções discursivas sobre as cotas e nos modos como os sistemas de coerência presentes na ordem social (neo)liberal em que vivemos constroem os estigmas dos alunos.

2. O sistema de coerência (LINDE, 1993) da meritocracia foi historicamente trabalhado de forma minuciosa por diversos segmentos político/sociais do Brasil e, conforme poderá ser visto na análise dos dados, esse sistema é atualizado pelas narrativas sobre cotas. As narrativas analisadas dos docentes trazem à tona especificidades sobre o campo de pesquisa, não podendo deixar de lado as características identitárias do próprio CEFET/RJ para que essa construção do ideal do mérito permaneça em atualização.

3. Com esta pesquisa, proponho pensar sobre uma ótica contemporânea desse discurso, atentando para quais Discursos estão na ordem social (neo)liberal sobre o mérito e as cotas. Como o Discurso de ordem socioeconômica, por exemplo, se manifesta em histórias individualizadas de sofrimento ou sucesso? Nas análises, esse tipo de questionamento também fez parte do entendimento sobre as construções discursivas dos estigmas nas narrativas.

4. As narrativas específicas desta pesquisa, o que chamo aqui de discurso com "d" minúsculo, atualizam o Discurso dessa ordem social. A relação entre os discursos é de mão dupla. Ela pode cristalizar, transformar em algo cada vez mais sólido, como acredito que o sistema de meritocracia seja, e naturalizar esse sistema a ponto de perder de vista que é um discurso social e não apenas natural, mas que é visto como natural, dada a transformação que o próprio discurso proporciona ao sistema.

5. É através dos itens de avaliação, pelo Sistema de Avaliatividade (MARTIN; WHITE, 2005; NÓBREGA, 2009; WHITE, 2004;), que eu busco entender nesta pesquisa a forma como os estigmas sobre cotas são construídos. 
O que fez com que eu combinasse a análise de narrativa com o Sistema de Avaliatividade foi a percepção de que, nas narrativas, havia uma forte carga avaliativa.

6. As estratégias retóricas de Wodak et. al (2009) entram nessa pesquisa para situar criticamente a construção discursiva dos estigmas sobre cotas. $O$ tom crítico necessário ao entendimento entre as relações micro e macro está na forma como os participantes das entrevistas utilizam determinadas estratégias do discurso para ratificar, modificar, corromper, transformar, reforçar, etc. os índices sobre cotas e sobre os alunos "cotistas".

E é nesse alinhavado de teorias que esta tese se apresenta. A partir do próximo capítulo, as construções discursivas dos estigmas imputados aos alunos que acessam o CEFET/RJ pela política de cotas ficam mais evidentes. A partir de agora, o entrecruzamento teórico-metodológico que proponho tomará forma analítica. 


\title{
5 \\ Como os estigmas são construídos discursivamente nas narrativas
}

\begin{abstract}
"Matemática, no primeiro bimestre, eu fiquei com três vírgula oito e aí eu falei pro meu pai 'olha fiquei com três vírgula oito, caraca não acredito', eu mesma não acreditei, eu olhei pra minha prova, eu fiquei 'caramba' porque quando a gente tava no ensino fundamental, é, geralmente os alunos que estudam aqui eles são os melhores da escola deles, então, tipo, eu tava acostumada a tirar nove, dez, eu olhei praquele três vírgula oito eu fiquei 'cara, como assim, tem alguma coisa errada, eu sou boa em matemática, que que tá acontecendo' e aí começou a entrar na minha mente que eu não era boa em matemática."
\end{abstract}

(Trecho da entrevista realizada com Yasmin, aluna participante desta pesquisa.)

Nesta seção que se inicia, trarei as narrativas dos docentes entrevistados e buscarei mostrar como os estigmas sobre os alunos que acessam o CEFET/RJ pela política de cotas se constroem discursivamente. Para isso, como já dito no capítulo 3 de metodologia, utilizarei a organização de estratégias retóricas que Wodak et al. (2009) elaboraram. Dentro da teoria que os autores desenvolvem, há diversas estratégias que contemplaram sua pesquisa, porém, para esta tese, seleciono apenas as que trouxeram sentido às construções que busco, e as ressignifico com novas terminologias, como já expliquei. Sendo assim, tomo as estratégias que interessam ao meu estudo como índices de um Discurso sobre determinada compreensão sobre cotas. Qual(is) sistema(s) de coerência(s) sobre cotas está(ão) sendo construído(s) nas narrativas a partir das estratégias?

Inicio, neste momento, a análise das narrativas em camadas, distribuídas nas seções deste capítulo 5, cada qual orientada por uma estratégia/índice sobre cotas. As estratégias retóricas fazem referência ao discurso ou narrativas dos docentes entrevistados e estão "contidas" na atualização ou manutenção da ordem social sobre as cotas. As estratégias presentes em meu estudo serão representadas em: narrativas de transferência de culpa ou responsabilidade; narrativas de trivialização das discriminações; narrativas de engajamento docente; narrativas de conservação do velho modelo; narrativas de descrédito dos alunos e da política de cotas; narrativas de descontinuação da política de cotas. Basicamente, essa sequência foi idealizada por mim com o intuito de organizar as construções discursivas. Portanto, esse arranjo que proponho não 
necessariamente aparece como padrão de ocorrência ordenada das narrativas ${ }^{33}$ dos docentes.

Identifiquei, nas narrativas dos docentes, o modo como os estigmas sobre "cotistas" e cotas são construídos por eles, e realizei a ordenação dessas narrativas da forma que proponho nas seções deste capítulo. Em um sobrevoo geral, adianto, por essa sequência de construções, que os professores, com suas histórias, transferem a culpa e trivializam as discriminações e as consequentes dores resultantes dessas situações. Então, eles se unem para projeção de imagens positivas sobre si e sobre a instituição para, assim, se defenderem diante da mudança trazida pela política de cotas. E a partir do descrédito da política e dos alunos, se constrói a ideia de que o melhor para todos é que a política de cotas não existisse.

Novamente reforço o que parece óbvio. Nesta pesquisa, e nas análises que apresento neste capítulo, não tenho o intuito de julgar ou medir quem é a favor ou contra as cotas. Tampouco colocar em xeque ou questionar o trabalho que tem sido realizado pelos docentes e pelas equipes pedagógicas para que o acesso e a permanência de todos os alunos seja cada vez mais efetiva. As críticas que faço neste estudo não são direcionadas pessoalmente aos docentes participantes desta pesquisa, mas ao sistema ideológico que anuvia nossas formações discursivas. Sistema esse que, no fim da linha, pode construir ou destruir identidades individuais dos alunos e retroceder os avanços sobre a luta pela democratização do acesso às instituições de ensino e contra as discriminações sociais e raciais.

Não me excluo das construções discursivas apontadas aqui, tendo em vista que faço parte deste universo e da cultura meritocrática à qual estamos todos expostos desde o berço. Estou ciente, também, de que a meritocracia não é o único Discurso que nos atravessa. Há questões que são típicas da colonialidade (BENTO, 2014) e do modo como as classes sociais, as raças e os gêneros entram em jogo nas relações sociais. Meu ponto aqui é chamar atenção para o que narramos, para as histórias que construímos e passamos à frente. Sugiro que, a partir dos resultados desta pesquisa, fiquemos atentos quanto a nossa responsabilidade sobre o que dizemos e com os avanços sociais na educação.

\footnotetext{
${ }^{33}$ Pode ser que o leitor se dê conta de que, ao longo deste capítulo, alguns docentes têm sido privilegiados em termos de números de narrativas aqui mencionadas e analisadas. Como estou trabalhando basicamente com excertos narrativos, nem todas as entrevistas renderam narrativas. Alguns docentes desenvolveram suas respostas de modo mais direto, oferecendo falas mais argumentativas do que narrativas e como é uma tese sobre narrativas eu pude aproveitar mais algumas entrevistas do que outras, o que acabou trazendo o desequilíbrio sobre a quantidade de narrativas de cada docente.
} 


\section{1. Narrativas de transferência de culpa ou responsabilidade}

A mudança de culpa ou responsabilidade é uma estratégia retórica encontrada nas narrativas dos docentes desta pesquisa, que indicia a diferenciação e o distanciamento entre "eles" e "nós". Foram encontrados discursos de exclusão social, anedotas e cenários fictícios, metáforas de naturalização, criação de estigmas e agência e responsabilidade seletivas. Os temas argumentativos que essas narrativas trazem (WODAK et al., 2009) são topos de isolamento, diferenciação e heteronomia. Tudo isso cria um índice não só de assimetria, mas de valor individual sobre a inferioridade ou a má qualidade do "cotista".

Para ilustrar, sigo com as narrativas selecionadas dos docentes e explico com maior detalhe quais itens lexicogramaticais valorativos foram encontrados. $A$ primeira narrativa que analiso, então, é a de Pedro. Encontro, no discurso do professor, a estratégia de construção do pessimismo ${ }^{34}$ (WODAK et al., 2009, p. 42), e mostro como se realiza nas análises que se seguem. Basicamente, por meio dessa estratégia, é construída a "luta impossível" à qual os alunos são fadados. Para reforçar o próprio argumento, a estratégia é utilizada com o viés de ameaça com um futuro temível, no caso dessa tese, para o CEFET/RJ.

\footnotetext{
34 Esse termo foi criado por mim como adaptação ao termo Cassandra Strategy, utilizado por Wodak et al. (2009). Seu significado original é o discurso da ameaça com um futuro temível, para reforçar o próprio argumento.
} 
Excerto 1: "eles mesmos se punem, eles se jubilam"

1 eles já passaram por isso no primeiro ano hh (.) então acho que 2 naturalmente isso acaba acontecendo (1.0) sabe (.) senão como Pedro 3 eu=como eu tenho costume de dizer eles abandonam (.) sabe (.) eu vejo 4 isso (.) é:: se ele não se sentir tão à vontade eles não se sentem (.) né 5 por isso é que eu sou contra (.) a:: situação do jubilamento que eu 6 costumo dizer eles mesmos eles se punem eles se jubilam

\begin{tabular}{llll}
\hline Allane & 7 & é um hum \\
\hline Pedro & $\mathbf{8}$ & porque eles não se sente acolhido pelo grupo \\
\hline Allane & $\mathbf{9}$ & um hum \\
\hline Pedro & 10 & então (1.5) eles acabam (1.0) pedindo pra sair como dizem o termo \\
\hline Allane & 11 & é \\
& 12 & né eles não ficam (1.0) porque não se sentem à vontade a turma deles \\
& 13 & passou (.) seguiu (.) e eles veem "poxa eu tô fora do grupo eu tô \\
14 & desassociado disso" (.) então (.) eles não têm uma estrutura maturidade \\
& 15 & não eu vou continuar o meu curso como na graduação quando você \\
16 & repete uma disciplina e você.:. continua tocando a sua vida (.) né eles \\
17 & são muito novos pra isso eles se sentem (.) desagrupados e eu vejo que \\
& 18 & eles acabam sain=eles preferem sair (2.0) é o que eu percebo assim \\
& 19 & como uma média
\end{tabular}

Allane 20 é e a gente viu lá né no próprio condmet né em que a gente acabou 21 vendo aquele dado lá rapidamente e a maioria é=é cota né

Pedro 22 é cota infelizmente é cota

\begin{tabular}{llll}
\hline Allane & $\mathbf{2 2}$ & então é se eles é infelizmente são são de cota \\
\hline & $\mathbf{2 3}$ & é (1.0) inclusive eu acho que:: (1.0) na pesquisa discente (.) havia (.) \\
& $\mathbf{2 4}$ & algo sobre essa pergunta (1.5) né (.) se=se ele já vivenciou se ele se \\
Pedro & $\mathbf{2 5}$ & sentiu:: né menosprezado se ele se como é=é=é alguma (.) alguma \\
& $\mathbf{2 6}$ & situação de racismo se ele visualizou e eu me recordo (2.0) que eu não \\
& $\mathbf{2 7}$ & vi (.) uma resposta assim muito efetiva dos alunos sobre isso
\end{tabular}

O estigma de fracasso iminente vai sendo desenhado na narrativa de Pedro nas linhas 6 ("eu costumo dizer eles mesmos eles se punem eles se jubilam"), 10 ("eles acabam pedindo pra sair como dizem o termo"), 12 ("eles não ficam porque não se sentem à vontade), 14 ("eles não têm uma estrutura maturidade") e 17 ("desagrupados"). Em todas essas avaliações que Pedro faz dos alunos, não há ainda a relação direta e assumida de que ele fala dos "cotistas". Mas logo na linha 22 ("infelizmente é cota") ele confirma, após se alinhar com a informação que eu mesma trago de que são alunos de cota, segundo os dados apresentados na comissão de docentes.

Essas construções ocorrem no âmbito da transferência de responsabilidade (WODAK et al., 2009, p. 36) e constantemente vêm em representações 
eufemísticas como forma de realização (WODAK et al., 2009) no discurso do docente. Há a eliminação da agência institucional e a autoria do fracasso é deliberadamente entregue aos alunos. Na construção da linha 10, não é a escola que não sustenta a permanência dos alunos, eles que optam por sair após entenderem sozinhos que não podem seguir. Pedro julga o comportamento do aluno que desiste em um movimento que me parece positivo por ser o padrão, o normal, o esperado. Não existe, por parte do docente, qualquer problematização do fato e, por isso, parece um julgamento positivo de estima social (MARTIN; WHITE, 2005; NÓBREGA, 2009; WHITE, 2004) no domínio da normalidade.

Esses itens de avaliação de Pedro em sua narrativa, colocam os alunos em sanção social (MARTIN; WHITE, 2005; NÓBREGA, 2009; WHITE, 2004). É quase um crime eles entrarem e não se sustentarem academicamente e emocionalmente na escola, já que usufruíram da política de cotas e "roubaram"35 a vaga que não era deles. Mas, ao mesmo tempo, me parece ser uma "normalidade" esperada a desistência e o pedido para saírem da escola. Sendo assim, há um conflito avaliativo nesse ponto.

Completando o sentido de culpabilização do próprio aluno pelo caminho não exitoso na escola, a narrativa de Pedro constrói essa difícil trajetória pela qual os alunos passam. Na linha 27, Pedro avalia que, aos seus olhos, não viu uma resposta "muito efetiva" sobre o sentimento dos alunos ("eu não vi uma resposta assim muito efetiva dos alunos sobre isso"). Adicionado ao item de modalização de baixa intensidade (HALLIDAY, 1985) "assim", o termo "muito efetiva" que completa 0 item é a avaliação de que a resposta que os alunos deram não foi suficiente para que ele entendesse como sendo a exposição do sentimento de discriminação por parte dos alunos. O julgamento de que não foi suficiente dá a ele mecanismos discursivos de trivializar a segregação e, assim, o estigma. Poderíamos, inclusive, completar essa linha de pensamento indicando que isso também reforça o estigma de "vitimismo" dos alunos, que vi também em outras narrativas docentes que não estão nesta seleção para análise.

Nesse mesmo final de narrativa encontramos o padrão das falas de outros docentes da pesquisa de culpabilizar o aluno por seu fracasso e sua saída da escola. Quando Pedro evoca o questionário aplicado pela escola aos alunos, ele sugere a transferência de responsabilidade do fracasso desses alunos a eles mesmos. É interessante observar a ausência de autoria ou até a eliminação de agência (WODAK et al., 2009, p. 36). O fato de a escola não estar preparada ou

\footnotetext{
${ }^{35}$ Esta metáfora será vista mais à frente, em outras análises.
} 
não prestar a devida assistência de permanência dos alunos acaba por se desfazer com esse discurso e, assim, é retirada qualquer culpa da instituição sobre a não sustentação do aluno matriculado.

Em movimento parecido de transferência de responsabilidade, a narrativa do professor Eduardo nos leva a outra forma de construção discursiva, que é o distanciamento que os docentes apresentam entre eles e as terceiras pessoas envolvidas nas narrativas. Essas pessoas se alternam com escolhas lexicais que passeiam entre "eu/nós" versus "você" e "eu/nós" versus "eles". Explico melhor após o excerto da narrativa de Eduardo ${ }^{36}$ :

\section{Excerto 2: "eles tiveram uma experiência de alunos de $1^{a}$ qualidade"}

\begin{tabular}{ccl} 
Eduardo & $\mathbf{1}$ & né (.) Pessoal do ensino médio pode falar melhor do que eu (1.0) \\
\hline Allane & $\mathbf{2}$ & eles já chegam prontos \\
\hline Eduardo & $\mathbf{3}$ & eles tiveram uma experiência (1.0) de alunos de primeira qualidade (.) \\
\hline Allane & $\mathbf{4}$ & uhum \\
\hline \multirow{2}{*}{ Eduardo } & $\mathbf{5}$ & que não precisavam nem da escola (2.0) de repente eles começaram \\
& $\mathbf{6}$ & a receber (2.0) uma enxurrada desses alunos que eram pra gente (.) \\
& $\mathbf{7}$ & faziam parte do nosso dia a dia \\
\hline Allane & $\mathbf{8}$ & uhum \\
\hline \multirow{2}{*}{ Eduardo } & $\mathbf{9}$ & e aí (.) qual é a opinião deles né é importante acho que mais do que \\
& $\mathbf{1 0}$ & mais do que a minha né
\end{tabular}

Eduardo é um professor do núcleo técnico e durante essa entrevista explica que os docentes do antigo "nível técnico" já estavam acostumados com alunos oriundos de classes socioeconômicas mais baixas, pois eles sempre atuaram com o segmento de ensino subsequente, antigo "pós-médio". Nesta modalidade, os alunos que cursavam os cursos técnicos têm já sua formação de Ensino Médio concluída e, em geral, as turmas são constituídas por alunos mais velhos, já trabalhadores e com suas famílias constituídas. Ou seja, Eduardo explica que é outro público alunado e separa, então, a sua atuação da docência dos professores do núcleo básico de ensino, antigo "nível médio".

Nesse momento, Eduardo posiciona-se como alguém mais experiente no que tange a receber "esses" alunos. No breve resumo de sua narrativa, na linha 1, ele já deixa evidente a transferência de responsabilidade em quem está mais habilitado a dizer o que vai dizer, se resguardando, assim, do que vai dizer. Eu auxilio nessa construção, na linha 2, referindo-me aos alunos do antigo sistema

\footnotetext{
${ }^{36}$ Para melhor organização e fluidez das análises, optei por reiniciar a contagem de linhas para cada narrativa de docente. Assim, sabendo a qual narrativa a análise se referencia, fica mais fácil encontrar a qual linha me refiro.
} 
de concomitância, dizendo que eles já chegavam alunos prontos, ou seja, sem faltas de conteúdos de base e oriundos dos melhores colégios particulares.

Eduardo continua sua narrativa orientando, na linha 3, e coconstruindo comigo a ideia de caracterizar os alunos do antigo sistema, dizendo que estes eram alunos de "primeira qualidade". Para que esses alunos sejam caracterizados como "de primeira qualidade", os alunos de hoje, oriundos da política cotas, não o são. Dou atenção ao item de alta gradação "primeira qualidade" que Eduardo usa. É interessante correlacionar com a fala que dá título a esta tese, quando a professora disse que a qualidade da escola iria acabar com a entrada dos novos alunos pela política de cotas. Esses discursos se interligam formando um índice sobre o aluno "cotista" como aquele que não tem qualidade. O item "primeira qualidade" aponta ao Julgamento de estima social (MARTIN; WHITE, 2005; NÓBREGA, 2009; WHITE, 2004) que é direcionado, nesse caso, aos alunos "não cotistas".

A ação complicadora da narrativa de Eduardo se dá nas linhas 5, 6 e 7, quando ele define a entrada dos alunos "cotistas" como uma "enxurrada". Enxurrada é um item, novamente, de alta gradação (HALLIDAY, 1985) que traz o significado do completamente incontrolável e devastador, como a enxurrada que a natureza produz. O não esperado, o que vem com força e descontrole, o que não se pede por. Ainda na ação complicadora, o professor retoma a ideia de que ele se exclui dessa surpresa, pois já estava acostumado a receber "esses alunos" que faziam parte do dia a dia dele. O item de avaliação "enxurrada" é de Julgamento de sanção social (MARTIN; WHITE, 2005; NÓBREGA, 2009; WHITE, 2004), trazendo a ideia de que é algo ruim contra o qual não é possível lutar.

Em sua avaliação e coda, nas linhas 9 e 10, Eduardo evoca os docentes do núcleo médio para a confirmação do que ele diz, tirando de si a responsabilidade de toda a avaliação que realizou sobre os alunos em sua pequena narrativa, concluindo, inclusive, que a opinião "deles" é mais importante do que a dele. Esse afastamento explícito não é somente sobre o significado e caracterização que ele diz sobre os alunos, mas também sobre o distanciamento que ele define entre os docentes do núcleo técnico e do núcleo médio, como se houvesse diferenças substanciais entre um e outro. A impressão que permanece é a de que são dois tipos de docentes diferentes atuando em duas escolas também diferentes, quando, na verdade, todos atuam com exatamente os mesmos alunos.

Esse movimento de afastamento sobre a responsabilidade do que se diz, que encontrei nas narrativas de Pedro e de Eduardo, ocorre quando há caracterizações sobre os alunos e relato de problemas relacionados a eles. 
Posicionamentos com os itens "nós"/"a gente", que afirmam ou contam diretamente algo, entram em cena quando o cenário é de salvação ou de resoluções, como na narrativa de Marcelo, no excerto 3.

\section{Excerto 3: falta educação}

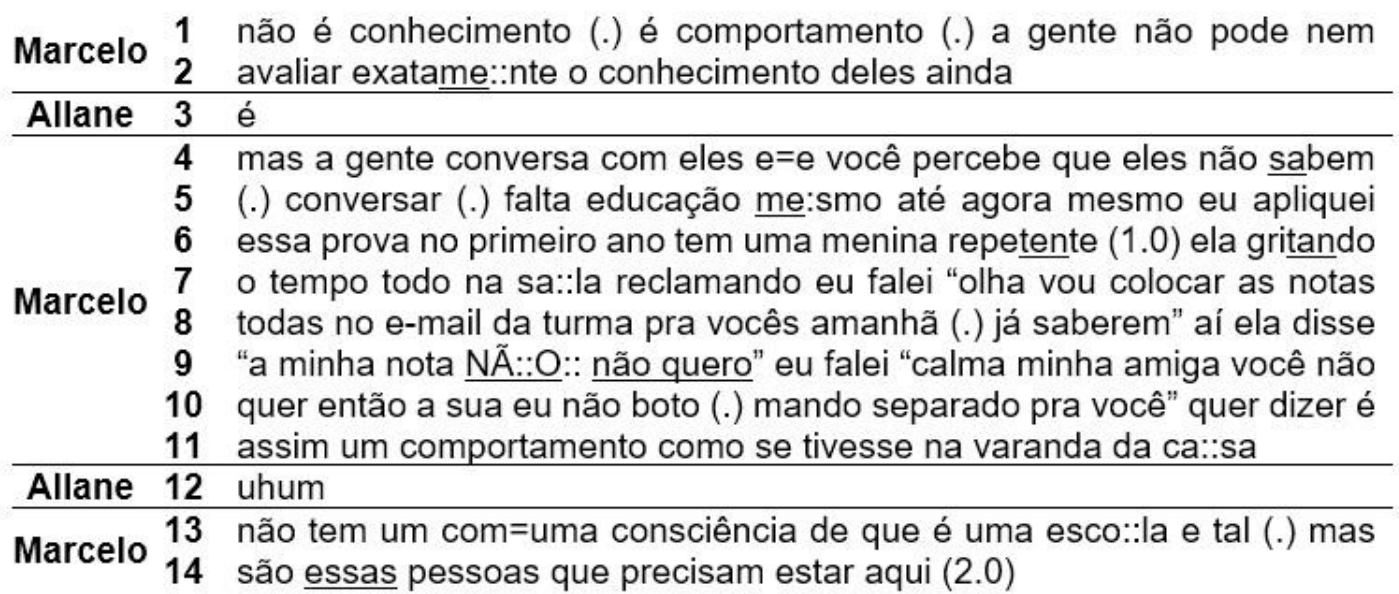

No resumo de sua narrativa, Marcelo já define que o comportamento dos alunos "cotistas" é o que está sendo avaliado, quando diz que não pode avaliar o conhecimento deles ainda quando estão entrando no CEFET. Para ele, não é possível ainda avaliar seu conhecimento, mas, já é possível julgar seu comportamento. Isso ocorre das linhas 1 a 5 , onde, dentro do resumo, está embutida uma micronarrativa cuja ação complicadora se revela no fato "da gente" conversar com "eles" e "você" perceber que eles não sabem conversar e falta mesmo educação (L4 e L5). Mais do que saber ou não, ter ou não uma formação, explicita-se uma compreensão de que práticas corporais podem ou não habitar o espaço, aquele espaço normatizado e disciplinar da escola.

Vale atentar ao movimento discursivo do docente: Marcelo traz para ele a tentativa de conversa "civilizada" utilizando o termo "a gente", distancia-se dos alunos que são "eles" e, por fim, quem percebe que eles não sabem conversar e que falta educação é "você". Ainda o item "falta educação" é de Julgamento de sanção social (MARTIN; WHITE, 2005; NÓBREGA, 2009; WHITE, 2004), indicando a avaliação do comportamento da aluna como fora de algum padrão que o docente estabelece como normativo.

Nas linhas 5 e 6, Marcelo sintetiza a narrativa ("agora mesmo eu apliquei essa prova no primeiro ano") avaliando a aluna protagonista de sua história como repetente. O docente segue a narrativa, na ação complicadora (L6 a L10) continuando a utilizar itens de avaliação de alta gradação ("gritando"; "o tempo 
todo", "reclamando"). Esses itens trazem caracterizações da falta de civilidade dos alunos esperada pelos docentes. A entonação que Marcelo dá ao reportar a voz da aluna que diz "não, não quero" também caracteriza dramaticamente o "mau" comportamento que ele narra da aluna. "Gritando" e "reclamando" também são itens de Julgamento de sanção social (MARTIN; WHITE, 2005; NÓBREGA, 2009; WHITE, 2004) que apontam para a ideia de que a aluna não sabe se portar em uma sala de aula ou, de forma mais ampla, em sociedade, o que constrói mais um estigma ao "cotista".

O professor segue para a avaliação (LABOV, 1972) das linhas 10 a 14 ("quer dizer é assim um comportamento como se tivesse na varanda da casa não tem uma consciência de que é uma escola e tal") definindo que a aluna não tem consciência do que é "uma escola". Ao indefinir o artigo que aponta a escola, Marcelo o direciona à ideia de que os alunos "cotistas" não sabem o que é qualquer escola. Escola como instituição de ensino, escola como local de formação, escola como locus de aprendizagem. A utilização do item "uma" marca o Julgamento de sanção social (MARTIN; WHITE, 2005; NÓBREGA, 2009; WHITE, 2004), que avalia o aluno como quem sequer sabe o significado do local onde está estudando e, nesse caso, o local para onde fez concurso para estudar. O paradoxo do cerne desse discurso está no fato de sabermos que o aluno se inscreve para a realização da prova do certame público para estudar no CEFET/RJ.

Esse discurso traz a ideia de que a aluna não escolheu a escola, sobrando a ela determinada obrigatoriedade de estar e frequentar um lugar que não faz sentido a ela, já que ela não tem consciência do que é "uma escola". Assim, esse significado é levado aos demais alunos que acessam pela política de cotas, coadunando com a ideia ou metáfora de senso comum de que os alunos entram no CEFET/RJ como se tivessem sido arrastados da calçada para dentro quando estavam acidentalmente passando pelas imediações. Parece cômica, mas é, na mesma proporção, trágica essa ideia. Sendo assim, mais um estigma é criado ao aluno "cotista", como aquele que não sabe nem o que está fazendo com a "chance" que lhes é dada.

Vale ressaltar, também, que Marcelo descreve, como todos os docentes, determinado comportamento dos alunos. Caracterizações de comportamentos ocorrem nas narrativas de modo que fica evidente a forma como são expectativas pré-definidas, que vão muito além da preocupação com conteúdos ou perda de "qualidade" de ensino/aprendizagem. Chega a particularizações sobre cada história contada como se quisessem deixar claro a tragicidade que envolve 
receber o aluno pela política de cotas. Mais para frente esse movimento também será analisado em outras histórias analisadas para esta tese.

Finalizando a narrativa de Marcelo, é interessante perceber que ele volta a afastar o aluno em sua coda, nas linhas 13 e 14, quando diz "mas são essas pessoas que precisam estar aqui". A formação "essas pessoas" aponta para algo distante dele. O item "mas" completa esse sentido, pois quase indica que "apesar de toda essa tragédia de comportamento" ou "infelizmente" é esse aluno que precisa estar na escola. Quando Marcelo utiliza o verbo precisar, ele está fazendo referência, contextualmente, aos primórdios da história do CEFET/RJ que tinha a filosofia de formar operários, que servem de "chão de fábrica ${ }^{37 "}$ às grandes empresas e indústrias.

Para evidenciar ainda mais esse movimento de afastamento de responsabilidades sobre o que é caracterizado sobre o aluno, em oposição à aproximação que é identificada quando o cenário é de salvação, a narrativa da professora Paloma conta a história de um aluno que, pela visão dela, conseguiu superar todas as suas "deficiências" em sua trajetória acadêmica. Paloma inicia a sua narrativa contando que, como professora do núcleo técnico, assim como Eduardo (excerto 2), já estava acostumada a receber no subsequente e pela concomitância externa alunos oriundos do estado, delimitando logo no resumo (L1 a L4) de sua narrativa que isso era um "problema" (L2).

\footnotetext{
${ }^{37}$ Esta forma de chamar os alunos formados pelo CEFET/RJ é comum entre os docentes da área técnica e fazem referência à formação mais específica de operacionalizar o que os engenheiros planejam. É como se o "chão de fábrica" colocasse a mão na massa dentro das empresas ou indústrias.
} 


\section{Excerto 4: "a gente sempre teve problema do garoto que era carente"}

1 assim vamo botar eu falo dos es=dos garotos do estado mesmo (.)

2 então a gente sempre teve proble:.:ma (.)do garoto que era carente a

3 gente identificava mas eles eram em menor número (1.0) então na

4 turma (.) a turma meio que absorvia (.) a gente (.)foi a primeira vez

5 que a gente recebeu metade da turma vi:.nda dali do sistema de cotas

6 (.) aí o que que aconteceu (1.0) eu tive alunos que entra::ram

Paloma 7 fenomenais (.) eles entraram por co:ta tinham consciência da::

8 deficiência deles (.) eu tenho um tá trabalhando agora lá em niterói (.)

9 ele tinha deficiências ele sabia que tinha (1.0) mas ele nunca baixou

10 a cabeça(1.0) a gente conversava que eu dava muito laboratório o

11 laboratório eu consigo conversar com eles que em aula eu não

12 consigo (1.0) ele falava "não fui mal mas eu vou estudar vou

13 recuperar" (.) e ele obteve assim o lu (.) chama até luan (.) luan costa

14 ele tá você acha ele no facebook ele é um menino excepcional

\begin{tabular}{|c|c|c|}
\hline Allane & 15 & já se formou né \\
\hline Paloma & $\begin{array}{l}16 \\
17 \\
18 \\
19 \\
20 \\
21\end{array}$ & $\begin{array}{l}\text { já se formo::u (1.0) ele passou pra aqui pro cefe::t (.) pra fazer } \\
\text { engenhari::a (.) aí o estaleiro onde ele tr=fez está:: gio chamou pra } \\
\text { trabalha::r já tá trabalha::ndo (1.0) a faculdade parece que ele teve } \\
\text { que trance::r ele ia fazer um outro ace::rto por causa do horá::rio né } \\
\text { (.) e ele tá morando inclusive em niterói (.) parece que ele tá } \\
\text { acomodado lá preferiu (.) se acomodar por lá }\end{array}$ \\
\hline
\end{tabular}

\begin{tabular}{lll}
\hline Allane & $\mathbf{2 2}$ & ficar mais próximo \\
\hline \multirow{4}{*}{ Paloma } & $\mathbf{2 3}$ & e.:le foi um garoto (.) ele entrou pobre (.) ele entrou ele era mu: ito \\
& $\mathbf{2 4}$ & truculento (.) truculento assim até no trata:.r ele hoje é extremamente \\
& $\mathbf{2 5}$ & educa:.do polido mas ele nunca baixou a cabeça (1.0) ele encarou de \\
& $\mathbf{2 6}$ & frente (.) ele sabia que tinha deficiência mas ele sabia que se ele \\
& $\mathbf{2 7}$ & conseguiu a vaga ele tinha seu mérito (1.0)agora eu tive garo:tos que \\
& $\mathbf{2 8}$ & botaram aquele:.: (.) como é que eu vou te explicar (.) eles falavam \\
& $\mathbf{2 9}$ & assim "eu vim da escola pública (.) eu sou fraco (.) eu não consigo ir \\
& 30 & pra frente" e esses ficaram então eu tenho (1.0) eu tive dos cotistas \\
& 31 & esses dois universos óbvio tem mais ge:nte no meio (.) do cami.nho \\
& 32 & né
\end{tabular}

A grande narrativa de Paloma é recheada de pequenas narrativas que fazem parte da grande ação complicadora. Essas pequenas narrativas trazem características meritocráticas que ela atribui ao aluno frente às adversidades dele que ela relata. A grande ação complicadora vem com diversos itens de avaliação que não só julgam, mas, também, caracterizam o aluno em diversos níveis. Esses itens igualmente identificam o aluno pontualmente, trazendo detalhes pessoais sobre a vida dele, onde mora, para qual empresa foi chamado para trabalhar, etc. Entendo essas descrições detalhadas como carga dramática que Paloma dá a sua narrativa, conferindo maior credibilidade ao que está contando e ao que contará em seguida. 
No início da sua grande ação complicadora, então, Paloma define como deficientes os alunos que entram através da política de cotas (das linhas 6 a 9). Vale destacar o peso que a palavra "deficiente" apresenta no senso comum, cujo significado se dá a pessoas com deficiências diversas como físicas, mentais, cognitivas, etc. Entendo que a docente tenha pensado em identificar a falta de base de conteúdo escolar dos alunos, mas a utilização de uma palavra com tanta força significativa me faz refletir sobre que características ela constrói para o aluno "cotista" para que escolhesse essa palavra. Essa escolha é utilizada durante toda a entrevista com Paloma e aparece em outras narrativas dos demais docentes também, sempre se referindo à deficiência de conteúdos. "Deficiente" ou "deficiências" são, então, itens de Julgamento de estima social (MARTIN; WHITE, 2005; NÓBREGA, 2009; WHITE, 2004) que se relaciona à capacidade do aluno "cotista".

A narrativa de Paloma mostra, também, o uso do termo "a gente" e "eu" que aproxima a docente do aluno de sua história, cujo principal ponto é o seu trabalho em conversar com ele e em fazê-lo "evoluir". Seu trabalho de salvação culmina na avaliação (LABOV, 1972) de sua narrativa (da linha 23 à linha 27), quando Paloma conta que o aluno saiu do estado "truculento" para "extremamente educado, polido". Esses últimos itens de avaliação são itens de Julgamento de sanção social (MARTIN; WHITE, 2005; NÓBREGA, 2009; WHITE, 2004), que envolvem avaliações à conduta dos alunos. Nesses pontos, são avaliados os comportamentos que condizem ou não com determinada normalidade que Paloma acredita moralmente ser a correta. É até possível afirmar que os mesmos itens são, também, de Julgamento de estima social (MARTIN; WHITE, 2005; NÓBREGA, 2009; WHITE, 2004), tendo em vista sua relação com a normalidade prevista pelas pessoas.

Ainda mantendo a reflexão sobre as aproximações ou distanciamentos pelo uso de "a gente", "ele" e "você" (WODAK et al., 2009), mais uma narrativa de Marcelo vem para exemplificar o movimento retórico sobre os problemas que os "cotistas" trazem. No excerto 5, Marcelo conta como se sentia ao receber os trabalhos dos alunos da primeira turma com alunos oriundos da política de cotas, em 2016. 
Excerto 5: "nós ficávamos em pânico"

\begin{tabular}{clll} 
Marcelo & $\mathbf{1}$ & no=na co::ta (.) você tinha na sala a primeira turma nossa que \\
& $\mathbf{2}$ & formou agora (.) em dois mil e ca=dezesseis né \\
\hline Allane & 3 & dezesseis é o ano passado \\
\hline & 4 & ela=ela entro::u (.) e a gente ficava meio=meio em pânico (.) nós \\
& 5 & ficávamos em pânico porque você recebia trabalhos que você não \\
Marcelo & 6 & conseguia ler (1.0) muitas vezes(.) e tentava entender aquilo e não \\
& 7 & conseguia e o outro na sala com texto que parecia que (.) foi escrito \\
& 8 & por um por um professor (.) enfim dava até pra desconfiar às vezes \\
& 9 & que não era dele
\end{tabular}

$\mathrm{Na}$ ação complicadora de sua narrativa (L4 a L8), Marcelo expõe seu sentimento de "pânico" sobre a entrada das cotas na primeira turma após a implantação da política de cotas no CEFET/RJ. A palavra "pânico", escolhida para descrever seu sentimento sobre os alunos, tem conotação de extremo medo. Vale antecipar aqui que, em algumas narrativas docentes, tenho encontrado o termo "susto" para definir também o sentimento do professor adentrando a sala de aula e se deparando com os alunos de cotas. Sob a perspectiva do avaliador (Marcelo), o Afeto (MARTIN; WHITE, 2005; NÓBREGA, 2009; WHITE, 2004) é expresso na forma de itens que avaliam as emoções dos docentes a partir da política de cotas, como "pânico" e "susto", que fazem parte de locuções adverbiais que realizam o intermédio de verbos de emoção (MAGALHÃES; NÓBREGA, 2015).

Marcelo relata que não conseguia ler os trabalhos dos alunos de cotas e enfatiza a sua história ao dizer, nas linhas 6 e 7, que havia, inclusive, um esforço de repetição nessa tentativa de entender o que os alunos escreviam ("e tentava entender aquilo e não conseguia"), porém, sem sucesso. Há um reforço na ideia de convencer que o que ele estava contando era tão real que ele até tentava a mais, mas não conseguia. Essa ideia de incompreensão se completa quando, ao final de sua ação complicadora e em sua coda avaliativa (L7 e L8), Marcelo traz a comparação com o aluno "não cotista", cujo texto era tão bem escrito que ele desconfiava que poderia ser de um professor, e não de um aluno.

Nessa oposição, o docente constrói mais um estigma ao aluno "cotista" como o que não sabe escrever ou se tenta escrever é tão incompreensível que mesmo com esforço não é possível entender, trazendo pânico aos professores. Do mesmo modo, constrói, também, a característica esperada do aluno "não cotista", que deve ser tão bom quanto um professor, a ponto de a qualidade de sua escrita se confundir com a de um docente. Essas descrições constroem o afastamento de responsabilidade do docente sobre um possível trabalho ilegível, quando a culpa por esse trabalho é exclusivamente do aluno responsável por ele. 
Do mesmo modo, são Julgamentos de estima social (MARTIN; WHITE, 2005; NÓBREGA, 2009; WHITE, 2004) que envolvem avaliações que questionam o quão capaz o aluno é de escrever um trabalho bom, ou o quão incapaz ele é a ponto de entregar um trabalho ilegível.

Atentando ao uso das primeiras e terceiras pessoas, cuja reflexão retomo neste momento. Nas linhas 4 e 5 , Marcelo traz para ele a responsabilidade sobre seu sentimento de pânico quando diz que "a gente ficava meio em pânico" e "nós ficávamos em pânico", mas assim que começa a relatar na ação complicadora o motivo do pânico, quem percebe que a redação do "cotista" estava ilegível é "você" ("você recebia trabalhos que você não conseguia ler", L5 e L6). Desse modo, Marcelo afasta o próprio julgamento que define que o "cotista" não consegue escrever de modo compreensível. Não é ele quem percebe isso, é um "você", que indica a indeterminação do sujeito coletivo que oculta os próprios professores.

Como uma forma também de afastar a responsabilidade sobre as opiniões que os docentes emitem em suas narrativas, surgem as anedotas contadas por eles das mais diversas formas, conforme veremos nos próximos excertos. As anedotas que surgem nas narrativas dos docentes parecem fazer parte do modelo construtivo dos estigmas dos alunos "cotistas".

No excerto 6, trago a narrativa da professora Ana para iniciar a exposição de como essas histórias são ilustradas pelos docentes.

\section{Excerto 6: "levei um susto"}

1 e assim (1.0) levei um susto $\uparrow$ porque tinha aluno que:: que

2 assim (.) é:.: vinha (.) não tinha NADA nem pra escrever (1.0)

3 >aí tinha um lápis eu falava assim esse lápis tá sem ponta< ele

4 começou a fazer ponta com:: com a unha (.) né com=com o

5 dente $\downarrow$ (2.0) pra começar a escrever $\downarrow$ (2.0) >aí falei assim cê

Ana 6 não tem caderno ele não< pra que caderno? falei assim temos

7 que comprar um caderno $\downarrow$ aí falou assim não tenho dinheiro pra

8 comprar caderno (2.0) hh aí começa: $\uparrow$ a gente lidar com os

9 problemas >falei assim "não peraí eu vou comprar um caderno

10 pra você" $<\mathrm{m}$ m aí co co começa a pensar hh (1.0) né (.) cara

11 não posso comprar caderno pra todo mundo (1.0)

\begin{tabular}{crll}
\hline Allane & 12 & pra todo mundo \\
\hline \multirow{2}{*}{ Ana } & 13 & né (.) não posso tirar xerox pra todo mundo >que que a gente \\
& 14 & vai fazer?< e começa já articulação $\uparrow$ \\
\hline Allane & 15 & é \\
\hline Ana & 16 & né om=com \\
\hline Allane & 17 & a instituição \\
\hline Ana & 18 & com a instituição:: $\uparrow(0.5)$ né que que pode fazer
\end{tabular}


Na linha 1 ("levei um susto "), a docente já inicia o seu resumo utilizando o item lexical "susto" para descrever seu sentimento frente ao que ela veria, o que nos leva a analisar a história a ser narrada como mais uma novidade ainda não vista no CEFET/RJ. Conduzo à interpretação de que há uma instabilidade sobre as normativas previamente estabelecidas na escola sobre o perfil de alunos ao qual os professores estavam acostumados. Pressupõe-se, em sua fala, a distinção de melhor (antes) e pior (depois) aluno. A diferença é que, dessa vez, a docente traz para o seu resumo a dimensão do Afeto para ela do item "susto", e define por Julgamento (MARTIN; WHITE, 2005; NÓBREGA, 2009; WHITE, 2004), em paralelo, a estima social do aluno "cotista", pela expectativa normativa.

Quando Ana inicia a orientação de sua narrativa ("porque tinha aluno que que assim é vinha não tinha nada nem pra escrever"), percebemos mais itens de avaliação. A professora constrói o aluno como o extremamente pobre que não possuía itens escolares básicos, evidenciando o seu Julgamento por estima social. Adicionalmente, recorro aos itens paralinguísticos para reforçar alguns aspectos de sua avaliação. Em seis segundos de fala (linhas 1 e 2), como avaliação encaixada, a professora dá três pausas e faz dois alongamentos de vogais. Esses elementos são entendidos como avaliativos por servirem como transmissores de ponto de vista do narrador (NÓBREGA, 2009, p. 80). A construção dramática da narrativa de Ana reforça o estereótipo, apontando para mais um momento de alinhamento ao sistema de coerência de senso comum que posiciona o aluno "cotista" como aquele que, por exemplo, nunca pegou em um lápis.

Seguindo a análise, Ana descreve o aluno quase que como um selvagem, nas linhas 4 e 5 . É intrigante essa descrição de comportamento quando se conhece a estrutura da escola e seu processo seletivo altamente concorrido. A carga dramática dada pela docente, com o uso de intensificadores lexicais como os advérbios ("com a unha", "com o dente"), carrega a intensidade da história enunciada pela docente. Do mesmo modo, trazem à tona o Julgamento por sanção social (MARTIN; WHITE, 2005; NÓBREGA, 2009; WHITE, 2004) que direciona o aluno "cotista" a implicações quase que legais sobre a sua conduta ou ética que esse aluno possui, pois implica uma avaliação sobre a atitude de estranhamento e de recriminação social (LIMA, 2014, p. 138).

O que encontramos na ação complicadora da narrativa da docente talvez seja o ponto alto da caracterização dos alunos "cotistas" em todas as entrevistas com os docentes realizadas para a pesquisa. Essa entrevista selecionada como 
exemplo de narrativa descreve a aproximação dos alunos a selvagens e abandonados prontos a serem "adestrados" por "superiores", representados pelos docentes do CEFET/RJ. Logo após essa descrição caricata do aluno "cotista", a docente continua sua ação complicadora e na linha 6 ("pra que caderno?") coloca o aluno como quem sequer sabe para que ele teria que possuir um caderno em sala de aula. Com isso, ela apresenta o questionamento do aluno no campo atitudinal do Julgamento de estima social (MARTIN; WHITE, 2005; NÓBREGA, 2009; WHITE, 2004).

Continua, nas linhas 6 e 7 ("temos que comprar um caderno"), colocando-se como agente de transformação do aluno, ao comprar o caderno necessário à escola. Essa construção descreve a metáfora que aludi anteriormente sobre o bom selvagem que é salvo por um homem civilizado, trazendo à tona o alinhamento ao pensamento colonial (BENTO, 2014). Aqui é possível, também, identificar outras instâncias avaliativas que ela faz no campo atitudinal, em especial, ao falar de si sobre a compra do material escolar, quando a professora se constrói positivamente, evidenciando seu Julgamento autoral por estima social positiva (MARTIN; WHITE, 2005; NÓBREGA, 2009; WHITE, 2004).

Considero a carga avaliativa dessa ação complicadora importante para o processo de caracterização dos alunos "cotistas", mesmo que não haja elementos avaliativos diretos, como adjetivos, que fariam referência direta ao aluno. Porém, entendo que a carga dramática dada pela docente ao narrar a história já é por si só um elemento de intensificação no julgamento sobre o aluno.

Ana caminha para a finalização da narrativa da linha 8 a 14, desenvolvendo a avaliação, a resolução e a coda de sua história. A resolução se dá a partir das linhas 8 e 9, onde a docente assume o aluno "cotista" como um problema. Ela posiciona cronologicamente o início desse "problema" ao dizer que "aí começa" e, nesse momento, entendo que, por contraposição, antes dos alunos "cotistas" entrarem no CEFET/RJ não havia problemas.

Duas instâncias de valoração no campo atitudinal são desenvolvidas aqui. Uma delas é o campo do Afeto negativo, ao dizer que "aí começa a gente lidar com os problemas" (compulsório) mostrando a preocupação frente à situação, em oposição ao início da primeira narrativa em que ela constrói como uma virada positiva "a nível espiritual". A outra é uma expressão avaliativa atitudinal de Julgamento de sanção social, qualificando o aluno "cotista" como "problema" (MARTIN; WHITE, 2005; NÓBREGA, 2009; WHITE, 2004).

Nesse mesmo ponto da narrativa, ainda, ela se constrói como a salvadora do aluno, quando repete que é ela quem compra o material necessário para a 
escola. Sob uma luz favorável, lança sobre si o olhar de distinção como uma pessoa de boas intenções, talvez tentando afastar-se, no momento da entrevista, da parte dos docentes que ela conhece que não concorda com a entrada de alunos através da política de cotas, sabendo que a pesquisa trata disso. Nesse ponto há, na dimensão do Afeto (MARTIN; WHITE, 2005; NÓBREGA, 2009; WHITE, 2004), o sentimento subentendido de dilema ou dúvidas sobre o que exatamente deve-se fazer para amenizar os problemas ou sustos que Ana leva com a entrada dos alunos novos.

O cenário de salvação revela a relação de movimentos de aproximação ou afastamento que aparecem no uso das palavras nas narrativas. Esse movimento de se colocar positivamente na história como salvador ocorre na pequena narrativa de Edson, que personifica a cota para posicioná-la como quem salva os alunos, como pode ser visto no excerto 7 .

\section{Excerto 7: "com certeza ela resgata muitos alunos"}

1 então eu acho que (.) se:: é=é (.) a cota ela (.) com certeza ela resgata Edson 2 (1.0) muitos alunos ela consegue tirar (1.0) se ela não salva todos é 3 pelo menos salvando alguns ali já é u::m grande Allane 4 já é alguma coisa né Edson 5 é já é alguma coisa

Junto ao meu alinhamento (L4), Edson constrói sua ação complicadora em um pequeno pedaço em que diz que "a cota com certeza ela resgata muitos alunos ela consegue tirar" e já avalia nas linhas 2 e 3 dizendo que "se ela não salva todos é pelo menos salvando alguns ali já é um grande é já é alguma coisa". Nessa pequena narrativa, a personificação da cota traz a representação da instituição como salvadora, mesmo que a cota seja vista como negativa pelo professor em outros pontos de sua narrativa. Quando a cota surge como algo positivo, é no caminho de representar o CEFET/RJ como quem salva.

Seguindo o movimento de construção de características, o professor Vicente narra a história de um aluno que confidenciou a ele não saber fazer conta alguma, conforme excerto 8 a seguir. 
Excerto 8: "pra você ver né o ponto que a gente chega"

\begin{tabular}{|c|c|c|}
\hline Vicente & $\begin{array}{l}2 \\
3 \\
4 \\
5 \\
6 \\
7 \\
8 \\
9\end{array}$ & $\begin{array}{l}\text { é teve u::m u::m garoto que tipo assim ele me entregou a prova em } \\
\text { branco (1.0) aí me chamou na porta falei "ô:: fulano eu não posso ir } \\
\text { porque eu to aplicando prova" "não eu quero falar u::m negócio pro } \\
\text { senhor que (.) eu tenho vergonha de falar aqui alto pros meus alunos } \\
\text { (.) pros os alunos colegas escutarem" ai eu fui ele falou "professor eu } \\
\text { não sei fazer cálculo conta nenhuma não tô conseguindo nem somar } \\
\text { na minha calculadora" (1.) então você vê (1.0) o ponto né que a gente } \\
\text { (.) que a gente chega então (.) eu não sei como é que de noite tem } \\
\text { cota também né (1.0) de noite no sorteio acho que tem }\end{array}$ \\
\hline & 10 & eu não sei eu acho que não acho que é só sorteio tem cota no sorteio? \\
\hline Vicente & $\begin{array}{l}11 \\
12 \\
13 \\
14 \\
15 \\
16 \\
17 \\
18\end{array}$ & $\begin{array}{l}\text { tem tem tem cota tem tem tem uma parte lá então a cota né no meu } \\
\text { meio de:: no meu ponto de vista né }(1.0) \text { eu acho que a cota não } \\
\text { funciona pra nada (1.0) né tipo assim (.) o aluno entra e não consegue } \\
\text { acompanhar o ritmo de quem (.) não é cotista e a aí a gente perde } \\
\text { porque os outros não entraram por conta dos cotistas (.) e os cotistas } \\
\text { acabam desistindo no meio do tempo do curso }(1.0) \text { então de repente } \\
\text { eu acho até que essa evasão que a gente conseguiu diminuir um } \\
\text { pouco no integrado é muito por conta das cotas (1.0) não sei se é o } \\
\text { mesmo (.) a mesma (.) }\end{array}$ \\
\hline
\end{tabular}

Em sua ação complicadora, Vicente constrói o aluno como recluso e com vergonha da situação que narra ( $L 3$ a $L 5$ ). Logo depois, ainda na ação complicadora, a voz do aluno é reportada para dizer que ele não sabia fazer conta nenhuma. Sequer na calculadora ele estava conseguindo somar. Novamente surge esse movimento de transformar o aluno "cotista" em semianalfabeto que não sabe fazer somas em calculadora ou em sua prova. Vicente usa itens de carga dramática para sua narrativa, como no resumo (L1) "ele me entregou a prova em branco". Aqui ele antecipa que o aluno não conseguiu sequer fazer uma questão de sua prova. Há o Julgamento de sanção social (MARTIN; WHITE, 2005; NÓBREGA, 2009; WHITE, 2004), pois o aluno entra no CEFET/RJ sem saber ler e fazer contas.

Sua pequena narrativa termina na linha 8 , após realizar uma coda avaliativa ("então você vê o ponto né que a gente que a gente chega") indicando uma sensação de movimento de saída de um lugar para chegada em outro ponto. Pressuponho que a saída tenha acontecido de um lugar que avalia ter sido o bom e, após as cotas, ter chegado a um que julga ser o ruim. É uma construção na dimensão do Afeto (MARTIN; WHITE, 2005; NÓBREGA, 2009; WHITE, 2004), sob a ótica do sentimento do avaliador (Vicente). Mas, ao mesmo tempo em que se sente consternado com o "ponto" onde se chegou após as cotas, o professor 
modaliza e não diz exatamente que ponto é esse, se é tão negativo ou não, indicando o baixo grau de comprometimento de Vicente (HALLIDAY, 1985).

Das linhas 12 a 19, Vicente faz uma avaliação da sua narrativa e emite opinião sobre as cotas e, apesar de não ser uma narrativa, deixo exposto no excerto para analisarmos. Nas linhas 12 e 13, o docente diz que as cotas não servem para nada, utilizando o termo "na minha opinião", o que afasta a responsabilidade sobre o que ele vai dizer (WODAK et al., 2009). A partir do momento em que decide retirar validações externas sobre o que vai dizer, ele se isenta de qualquer oposição que possa ocorrer sobre o que ele diz. É esse movimento que acontece quando ele diz que é a opinião dele, não sobrando espaço para que ele dê certeza sobre o que vai dizer, em um movimento parecido com "posso estar errado" e por isso é só "minha opinião". Esses são itens modais de baixa intensidade que mostram o baixo grau de comprometimento (HALLIDAY, 1985) com o que o professor narra.

Das linhas 13 a 16, encontro grande quantidade de avaliações sobre o aluno "cotista", com itens de alta gradação como "não consegue", "perde", "desistindo". São ações e sanções já esperadas para o "cotista". Ele entra e não consegue acompanhar o curso, "a gente perde" porque eles impediram a entrada do aluno que os professores desejam e ao final desistem do curso. Vicente fala como se o aluno estivesse jogando fora a vaga que sequer era dele. Essa ideia traz uma avaliação de Julgamento de sanção social (MARTIN; WHITE, 2005; NÓBREGA, 2009; WHITE, 2004) embutida, tendo em vista que o aluno não sabe aproveitar a vaga que Ihe foi "cedida".

Acreditando que é na contação dessas histórias que aparecem as construções projetadas sobre os alunos de cotas, compartilho aqui mais histórias contadas pelos docentes que expõem outro tipo de caracterização, que é a construção do aluno agressivo e com comportamento fora de padrões. $O$ professor Julio narrou duas histórias sobre alunos "cotistas" em que esta descrição fica explícita. O excerto 9 mostra a primeira narrativa dele. 
Excerto 9: "ele levantou pra partir pra cima de mim"

\begin{tabular}{|c|c|c|}
\hline Julio & $\begin{array}{l}1 \\
2 \\
3\end{array}$ & $\begin{array}{l}\text { por outro la::do tem um caso de menino (3.0) Ricardo (1.0) né posso até } \\
\text { depois pra efeito de pesquisa (.) pesquisar nos meus diários pra saber } \\
\text { o nome dele completo (1.0) }\end{array}$ \\
\hline Allane & 4 & aham \\
\hline Julio & & $\begin{array}{l}\text { o Ricardo (1.0) a primeira vez que ele tirou uma nota baixa (1.0) ele } \\
\text { levantou (.) pra partir pra cima de mim (.) né }\end{array}$ \\
\hline Allane & 7 & na sala de aula isso? \\
\hline Julio & $\begin{array}{l}8 \\
9 \\
10 \\
11 \\
12 \\
13 \\
14 \\
15 \\
16 \\
17 \\
18 \\
19 \\
20 \\
21 \\
22\end{array}$ & 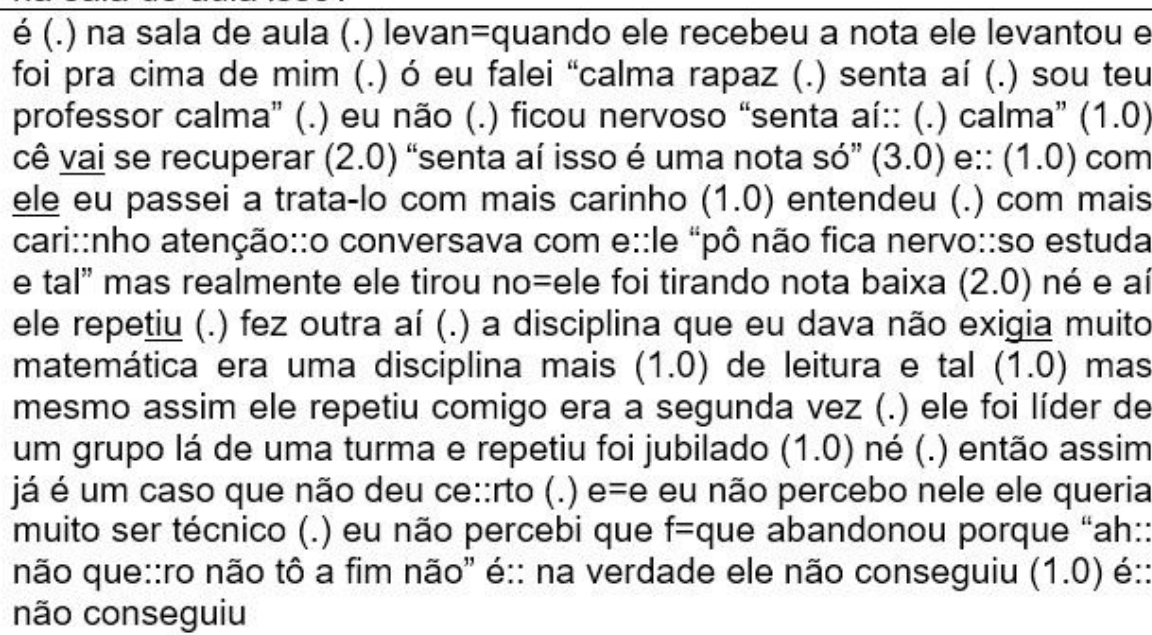 \\
\hline
\end{tabular}

No resumo de sua narrativa, nas linhas 5 e 6, Julio conta que o aluno Ricardo se levantou de sua cadeira na sala de aula para agredi-lo e desenvolve com mais detalhes a história na ação complicadora, da linha 8 à linha 18. Julio repete três vezes a palavra calma para explicitar que ele acalmou o aluno. A formação "foi pra cima de mim" (L9) está na dimensão do Julgamento de sanção social (MARTIN; WHITE, 2005; NÓBREGA, 2009; WHITE, 2004), que relata um potencial crime do aluno "cotista" que não se controlou e decidiu brigar através de agressão física com o docente.

Julio não somente se constrói como quem acalmou o aluno, mas também como quem o guiou com orientações em sua trajetória acadêmica, como ao mandar ele estudar, apesar de não ter sido exitosa ao final. Na linha 12, o professor relata que passou a tratar Ricardo com "mais carinho", o que pressupõe uma necessidade do aluno de receber carinho. Um direcionamento à atenção diferenciada é dado ao aluno "cotista", o que não é visto sendo oferecido aos alunos "não cotistas". Nenhum docente conta histórias de que teve que dar mais carinho aos alunos em geral para que eles se acalmassem e melhorassem em seu caminho acadêmico.

Nas linhas 19 a 22, Julio realiza a coda avaliativa da narrativa começando dizendo que "já é um caso que não deu certo" e concluindo que o aluno foi jubilado não por falta vontade, mas por não ter conseguido. Já na narrativa sobre a aluna 
Mariana, que exponho no excerto 10, Julio conta a história de melhora da aluna que chegou ao CEFET/RJ reclusa e maltrapilha.

\section{Excerto 10: "bem bem bicho do mato"}

\begin{tabular}{|c|c|c|}
\hline Julio & $\begin{array}{l}1 \\
2 \\
3 \\
4 \\
5 \\
6\end{array}$ & $\begin{array}{l}\text { (...) que ainda tava uma confusão (1.0) o nome dela é Mariana (1.0) não } \\
\text { tem assim muita:: uma história não sei se é interessa::nte né mas eu } \\
\text { lembro que eu fui professor (.) do primeiro período (.) e essa } \\
\text { transformação (1.0) ela se revela em alguns alunos (1.0) né:: (.) então } \\
\text { a Mariana (.) era um bicho do ma::to né eu sem ela sentava num ca::nto } \\
\text { ali você explicava algo um bicho do mato }\end{array}$ \\
\hline Allane & 7 & aham \\
\hline Julio & $\begin{array}{c}8 \\
9 \\
10 \\
11 \\
12 \\
13 \\
14\end{array}$ & $\begin{array}{l}\text { mal perguntava (.) né (.) notas be::m medianas né e be::m=be::m bicho } \\
\text { do mato e aí (.) eu não dei mais aula pro integrado (.) né e eu reencontro } \\
\text { ela ago::ra uma aluna (.) que é até questão do uniforme né (.) que muda } \\
\text { até o abando::no (.) o aquela calça muito toda rasga::da short rasga::do } \\
\text { (.) é (.) isso na minha visão significa uma melhoria na auto estima (1.0) } \\
\text { né (.) então quando ele ou até mesmo quando ele não usa uniforme } \\
\text { chefa }\end{array}$ \\
\hline & & aham aham \\
\hline
\end{tabular}

O professor mantém a caracterização primitiva, desenhada, desta vez, por uma "transformação" (L4). A palavra pressupõe a mudança de um estado ruim para outro melhor e parece ser atribuída aos alunos de cota em geral, sendo a escola a sua salvadora. No início da ação complicadora (L5), Julio usa a expressão "bicho do mato" para descrever a aluna Mariana. A expressão completa o sentido de comportamento selvagem atribuído aos alunos de cota, não somente por Julio, mas por mais docentes nas entrevistas que realizei, como a da professora Ana (excerto 6). A expressão bicho do mato conota a pessoa que se esquiva do convívio social. Essa expressão de avaliação está na dimensão do Julgamento de estima social (MARTIN; WHITE, 2005; NÓBREGA, 2009; WHITE, 2004), que se relaciona à normalidade ou falta de normalidade da aluna que se comporta como um "bicho do mato".

Essa construção discursiva é bem parecida com o que Julio faz de Ricardo, assemelhando os alunos à figura rústica de indivíduo não civilizado. Vale ressaltar que Julio utiliza intensificadores de alta gradação, ao repetir "bem bem bicho do mato" e repete a expressão, também, três vezes, o que traz a carga dramática para a sua narrativa e reforça a característica selvagem que ele atribui à Mariana. O item "bem", que é repetido para dar ênfase, é um item com alto grau de comprometimento (HALLIDAY, 1985) por parte do docente.

Ainda na ação complicadora, nas linhas 10 e 11, o professor diz que Nathalia mudou o "abandono" e descreve roupas rasgadas, usando mais itens de alto grau 
de comprometimento (HALLIDAY, 1985) que intensificam gramaticalmente o significado de sua avaliação, como "muito" e "toda". É um cenário que parece que Nathalia andava dentro da escola como uma mendiga, vestida de trapos rasgados e entocada ao canto da sala de aula sem saber como conviver socialmente. são, também, itens de Julgamento de estima social (MARTIN; WHITE, 2005; NÓBREGA, 2009; WHITE, 2004), que avaliam a aluna por um viés de rebaixamento de sua estima na comunidade escolar do CEFET/RJ,

Da linha 12 à linha 14, Julio realiza uma coda avaliativa e julga como uma "melhoria" na autoestima da aluna o fato de a escola ter mudado estas características dela, incluindo roupas diferentes do uniforme exigido pela escola. Essa história é contada em contraposição à história sobre Ricardo, que não deu certo no CEFET/RJ. Para contar que Nathalia deu certo na escola, ele a constrói com o estigma do comportamento esperado para um aluno "cotista" como selvagem, recluso e destacado do convívio social e escolar, cuja evolução se dá dentro do CEFET/RJ e, consequentemente, é atribuída aos professores o poder da salvação.

A escola como forte elemento de redenção também aparece em mais uma narrativa de Paloma, que exponho no excerto 11:

\section{Excerto 11: "eles não iam aguentar"}

1 não é todo mu::ndo (.) que tá preparado allane pra trabalhar essa Paloma 2 diversidade (1.0) a gente tem que ver que do outro la::do eles vêm eles 3 também (.) estranham né é a música que escuta que é difere::nte 4 alguns viajam pra fora eu tenho aluno que vai pro exterior

\begin{tabular}{|c|c|c|}
\hline Allane & 5 & um hum \\
\hline Paloma & $\begin{array}{l}6 \\
7\end{array}$ & $\begin{array}{l}\text { outros não vão nem ali a niteró::i não vão nem a se=a são gonçalo que } \\
\text { a gente brinca }\end{array}$ \\
\hline Allane & 8 & $\operatorname{sim}$ \\
\hline Paloma & $\begin{array}{l}9 \\
10 \\
11 \\
12 \\
13 \\
14 \\
15 \\
16\end{array}$ & $\begin{array}{l}\text { aquela vidinha (.) no mundo deles ali vão sair agora né que tã::o } \\
\text { trabalhando então (.) eu tive alunos do outro lado que também não se } \\
\text { adaptaram (1.0) mas assim eu não sei dizer allane se numericamente } \\
\text { (.) foi tão bom assim o resultado mas foi melhor do que eu esperava (.) } \\
\text { isso com certeza (.) eu ach=eu achei que ia ser uma evasão maio::r um } \\
\text { arraso maio::r (.) e que eles não iam aguentar (.) eu realmente esperava } \\
\text { (.) eu falei assim "gente eles vão vim muito fracos" (.) porque os da } \\
\text { noite são assim }\end{array}$ \\
\hline
\end{tabular}

A primeira questão que Paloma traz, no resumo de sua narrativa ("não é todo mundo que tá preparado Allane pra trabalhar essa diversidade a gente tem que ver que do outro lado eles vêm eles também se estranham né"), é delimitar 
que nem os docentes e nem os alunos "não cotistas" estão preparados para os alunos "cotistas". Os professores que não estão preparados e os alunos que se "estranham". Isso desenha a ideia do "cotista" como o aluno a ser suportado pelos demais, a ponto de se estranharem na escola. O verbo estranhar traz o sentido de algo visto como fora do comum e, assim, passível de ser censurável e está na dimensão de Julgamento de sanção social (MARTIN; WHITE, 2005; NÓBREGA, 2009; WHITE, 2004). Como é uma política compulsória e a legislação não pode deixar de ser atendida, o tratamento passa por ações e discursos de evitação.

$\mathrm{Na}$ ação complicadora, Paloma lista as diferenças mais visíveis a ela que são as relacionadas à viagem ou à mobilidade social. Da linha 4 à linha 10, a docente conta que ela tem alunos que não vão nem ao bairro vizinho. Há aqui um Julgamento por estima social (MARTIN; WHITE, 2005; NÓBREGA, 2009; WHITE, 2004), trazendo à tona o posicionamento crítico valorativo de Paloma sobre os alunos "cotistas".

Em contraposição, está o outro aluno que ela tem em sala de aula, que faz viagens exteriores. Essa caracterização é típica do aluno antigo do CEFET/RJ, que hoje ocupa $50 \%$ das vagas. No início de sua ação complicadora, Paloma precisa marcar primeiro o que é o aluno esperado para o CEFET/RJ, o que viaja ao exterior, para depois desenvolver a dificuldade do aluno "cotista", que vai sequer ao bairro vizinho.

Nas linhas 9 e 10, Paloma traz um pequeno ponto de virada (MISHLER, 2002) ("vão sair agora né que tão trabalhando") e considero que, nesse momento, ela constrói a característica de redenção que o CEFET/RJ tem. Somente após eles entrarem na escola e, por consequência do estágio obrigatório, eles terem que trabalhar em alguma empresa para cumprir as horas exigidas, eles saem daquela "vidinha no mundo deles ali" (L9) e conseguem a mobilidade social/urbana básica. Há nesse ponto uma avaliação moral por parte da professora do comportamento humano e, por isso, o Julgamento de estima social (MARTIN; WHITE, 2005; NÓBREGA, 2009; WHITE, 2004), representado pela crença de Paloma sobre a vida dos alunos "cotistas".

Peço atenção ainda aos itens "vidinha" e "mundo deles ali", que mostram afastamento da docente sobre os alunos. Não somente o afastamento, mas também um determinado sentido inferiorizado à vida e ao "mundo" dos alunos, devido ao uso do diminutivo e ao pronome "ali", que marca com evidência o afastamento dela mesma. O pronome, junto ao diminutivo, delimita os espaços físico e social da docente em relação aos alunos "cotistas", indiciando o lugar social de cada um. Esses itens juntos à expressão "eu não sei dizer" (L11), são 
modais de valor alto utilizados por Paloma, que apontam para o alto grau de comprometimento (HALLIDAY, 1985) no discurso da professora.

A avaliação (LABOV, 1972) da narrativa de Paloma vai da linha 11 à linha 14 , e denuncia o pessimismo que a professora guardava para si da espera por um "arraso" (L14). Paloma faz uso da transferência de responsabilidade do que vai dizer ao afastar alguma legitimação formal sobre o que vai dizer ("assim eu não sei dizer Allane se numericamente foi tão bom assim o resultado"), nas linhas 11 e 12, em um movimento de modalização (HALLIDAY, 1985). Assim, ela constrói o aval para continuar a dizer que o resultado após as cotas foi melhor do que o arraso que ela aguardava, blindando seu argumento com colocações vagas que o tornam incontestáveis, já que é "só uma opinião dela que ela não tem certeza".

$\mathrm{Na}$ linha 14 ela faz uma avaliação encaixada ("e que eles não iam aguentar"), completando a exposição do que era esperado após a política de cotas. Mais uma vez se constrói a expectativa de que a evasão aumentasse e de que os alunos "cotistas" abandonassem o CEFET/RJ. Paloma finaliza a sua narrativa com a coda avaliativa nas linhas 14 e 16 ("eu realmente esperava eu falei assim gente eles vão vim muito fracos porque os da noite são assim") em que compara os alunos da política de cotas do ensino integrado com os alunos do ensino subsequente, cujo turno é à noite e já foram descritas as características sobre eles mais anteriormente.

Nos excertos 12 e 13, trago duas narrativas do professor Luciano para ilustrar a expectativa sobre os alunos após a implantação da política de cotas no edital de 2013.

Excerto 12: "mais gente que tava entendendo menos o que eu tava falando"

\begin{tabular}{ccl} 
Allane & 1 & e aí quando você viu (.) qual seria a realidade o que que você viu (.) e \\
& 2 & se modifico::u comportame::nto \\
\hline 3 & não (.) em relação ao comportamento eu não vi nada em minha aula \\
4 & eu não vi nada (.) de mudança de compor=de comportamento talv=o \\
$\mathbf{5}$ & que eu vi foi mudança de=de (.) assim mais gente com menos (1.0) é \\
6 & eu percebendo mais gente que tava entendo menos o que eu estava \\
7 & falando (1.0) interagindo menos ou::ou com mais dificuldades de:::de \\
8 & de conseguir concilia:::r de uma forma eficiente (.) prestar atenção no \\
9 & que eu to fala:::ndo anotar uma fra::se copiar alguma coisa do qua::dro \\
10 & ou entender um ma::pa fo=foi faltando:: (1.0) esses elementos que \\
11 & dão a habilidade ao estudante eu vi isso isso continuou existindo isso \\
12 & existiu mais pelo menos eu perce=passei a perceber mais não sei se \\
13 & foi influenciado pelo fato de saber (.) que tinha cota ou não (.) mas eu \\
14 & comecei a perceber mais isso:: é:: principalmente em turmas de \\
15 & primeiro ano quando entrava:: turmas maio::res também isso foi um \\
16 & (.) um pouco mais agitadas isso em geral assim mesmo sendo \\
17 & primeiro ano antig=você tem um volume maior de gente um grupo \\
18 & maior de=de que tá ali mai::s mais inquieto ali na naquela postura \\
19 & tradicional de aluno (1.0) né de senta::r ouvir você fala::ndo e tal
\end{tabular}


Eu inicio a pergunta direcionada ao professor questionando se ele havia modificado seu próprio comportamento, representando os demais docentes de sua coordenação, após visualizar a realidade dos alunos com a entrada da política de cotas. Porém, Luciano logo entende que estou perguntando sobre o comportamento dos alunos e começa a discorrer sua opinião sobre a modificação e o esperado dos alunos após a nova forma de entrada.

Em seu resumo, o professor retira sua responsabilidade sobre o que vai dizer, colocando intensificadores lexicais, como "nada", sendo repetido nas duas vezes em que ele também repete que não viu nada, linhas 3 e 4 . Essa negação também é avaliativa e ocorre mesmo ele seguindo com sua narrativa e trazendo mais à frente o relato de mudanças exatamente sobre o que ele, no resumo, diz não ter visto. Com essa escolha lexical, Luciano gera ressalvas sobre o próprio argumento, criando barreiras incontestáveis, em movimento parecido com o que a docente Paloma fez na narrativa anterior à de Luciano.

Luciano desenvolve a ação complicadora da linha 5 até a linha 19, descrevendo gradativamente diversos eventos que marcam as mudanças de comportamento, que ele iniciou dizendo que não havia percebido. A enumeração de mudanças descreve menos gente entendendo o que ele estava dizendo, menos interação, mais dificuldades de conseguir prestar atenção no que é dito em sala de aula ou entender um mapa e mais dificuldade em anotar uma frase. Todas essas são avaliações de Julgamento de estima social (MARTIN; WHITE, 2005; NÓBREGA, 2009; WHITE, 2004), sobre a qual é contestada a capacidade dos alunos de estarem em sua aula e no CEFET/RJ.

É importante ressaltar o uso dos intensificadores gramaticais por Luciano, que indicam que, após as cotas, há "mais" gente com dificuldades e "menos" gente interagindo ou entendendo o que é explicado em sala de aula. Esses advérbios definem e separam cronologicamente em que momento havia mais ou menos alunos na sala de aula com as características aguardadas pela comunidade escolar. Sendo assim, os intensificadores modelam esse comportamento esperado e o definem, indiciando mais estigmas ao aluno "cotista", junto ao Julgamento de estima social (MARTIN; WHITE, 2005; NÓBREGA, 2009; WHITE, 2004) já desenvolvido por Luciano em outros pontos de sua narrativa.

Nas linhas 12 e 13, Luciano realiza uma avaliação encaixada na ação complicadora de sua narrativa ("não sei se foi influenciado pelo fato de saber que tinha cota ou não"). Assim, o professor presta contas sobre o fato de haver a possibilidade de ele ter percebido essas diferenças somente após ter consciência 
da implantação da política de cotas. Dessa forma, ele isenta a sua opinião quando apresenta a possibilidade dessas características sobre os alunos já estarem ali antes das cotas, mas, com a informação da implantação da política, ele passa, então, a reparar nas características.

Isso converge com o resumo de sua narrativa que diz, então, que não viu mudança, fechando o ciclo de afastamento de responsabilidade do argumento do discurso do docente. Quase que desenhando, visualizo esse movimento circular da seguinte forma: "não vi mudança" - "lista de mudanças" - "mas as mudanças já poderiam estar ali antes das cotas e eu não vi" = afastamento de responsabilidade. E assim, Luciano finaliza sua narrativa na coda avaliativa (L17 à L19), descrevendo que "você" tem um volume maior de alunos inquietos, fora da postura tradicional de aluno que senta e ouve o que "você" está falando.

Novamente o item "você" indetermina e afasta quem recebe o aluno problemático e inquieto, que não sabe prestar atenção no que é dito em sala de aula. Isso evidencia, mais uma vez com o uso de itens gramaticais que intensificam o significado dado por Luciano (volume "maior", grupo "maior"), a diferenciação cronológica entre antes e depois das cotas. O volume torna-se maior, trazendo uma nuance estatística a essa delimitação de espaço/tempo. Esses itens também são altamente avaliativos, pois são itens de Julgamento de sanção social (MARTIN; WHITE, 2005; NÓBREGA, 2009; WHITE, 2004), que entrega ao aluno características que fogem às regras de comportamento em sala de aula e, ao mesmo tempo, são itens de estima social (MARTIN; WHITE, 2005; NÓBREGA, 2009; WHITE, 2004), pois aguardam do aluno determinado comportamento normativo que não é cumprido a partir do momento em que Luciano percebe "maiores" inquietações.

Na segunda narrativa de Luciano, no excerto 13, há mais descrições do perfil do aluno modificado após a política de cotas. 
Excerto 13: "não tava acostumado a anotar nada na sala de aula"

\begin{tabular}{|c|c|c|}
\hline & 2 & [não] perfil do aluno mudado (.) \\
\hline & 3 & perfil do aluno muda:.:do a gente viu que tinha gente com mais mais \\
\hline & 4 & é:: mais dificuldade e essa dificuldade de abstração essa dificuldade \\
\hline & 5 & (.) de hábitos de estudo de:. e também que não tava acostumado a \\
\hline & 6 & anotar nada na sala de a:.ula é.: (.) ficavam muito só preocupado em \\
\hline & 7 & copiar o negócio do quadro e aí às vezes nem conseguiam (.) ao longo \\
\hline & 8 & da a::ula copiar o que tava no quadro ou que tava sendo projetado \\
\hline & 9 & porque eles não tinham esse hábito (.) então (.) eu nunca procurei \\
\hline & 10 & saber quem é quem se alguém é cotista ou não é:.: assim eu percebia \\
\hline & 11 & alunos com essa dificuldade (.) que tinha antes também (.) mas era \\
\hline & 12 & uma:: eles representavam menos na turma (.) eles eram menos \\
\hline & 13 & visíveis hoje é até ruim porque eles eram engolidos por pelo processo \\
\hline & 14 & mas a:: é:: nesse primeiro ano de integrado eles ficaram mais visiveis \\
\hline & 15 & e a gente (.) tentou a partir de uma mudança de=de forma de \\
\hline Luciano & 16 & apresentar conteúdos é=é junta::r e outras formas mais de $=$ de (.) \\
\hline & 17 & pensando em coisa de $=$ de (.) passar mais vi :.deos pra deba:te (.) \\
\hline & 18 & menos leitu: ra (.) porque era uma dificuldade (.) grande também de \\
\hline & 19 & interpretação de $=$ de de:: de leitura então as leituras mais pesa:das \\
\hline & 20 & não tavam dando certo então mais pesada em termo (.) mas (.) que \\
\hline & 21 & quem tava começando a lidar também com (1.0) co:m grupos que:: \\
\hline & 22 & (1.0) tinham (.) não tinham esses hábitos (.) aí sim a:: a gente (.) nosso \\
\hline & 23 & caso (.) pouquíssimas aulas por semana (.) duas aulas (.) parar pra \\
\hline & 24 & atender (.) é: esses grupos "ah vamos então fazer práticas de como \\
\hline & 25 & ler bem" isso não cabia (.) e nem dava eu também acho que deveria \\
\hline & 26 & ser uma coisa mais ampla entã:o a gente tentou pelo que que nos \\
\hline & 27 & cabia (.) uma coisa mais rápida de tenta:r (.) agrupar alguns conteúdos \\
\hline & 28 & e uma forma de apresentá-los mais (1.0) ma: is (.) é:: meno:s pesada \\
\hline & 29 & no sentido de ter leitura ou de necessidade do cara ficar (.) anotando \\
\hline & 30 & prestar=ter muita atenção na aula: (.) o tempo todo \\
\hline
\end{tabular}

Eu pergunto se aconteceu de eles mexerem no currículo para atender a alguma dificuldade esperada para os alunos após a política de cotas, e Luciano faz um grande resumo da linha 2 à linha 6 . $O$ docente descreve que passaram a ver "mais" alunos com dificuldade de abstração e de hábito de estudo, inclusive detalhando, novamente, que não estavam acostumados a anotar nada em sala de aula. Mais uma vez, como em sua narrativa anterior, Luciano realiza uma avaliação com Julgamento de sanção social (MARTIN; WHITE, 2005; NÓBREGA, 2009; WHITE, 2004), que posiciona o aluno "cotista" como aquele que tem um jeito diferente de estar na sala de aula do CEFET/RJ por não conseguir acompanhar as aulas.

Da linha 6 à linha 25, Luciano desenvolve uma ação complicadora grande, na qual deixa evidente ações mecanizadas dos alunos que apenas copiavam a matéria sem entender o sentido do que havia escrito no quadro. Junto a isso, ele reforça, nas linhas 9 e 22, que o aluno não tinha o "hábito" do que Luciano entende por estudar de forma eficiente. Essas são avaliações de Julgamento de sanção 
social (MARTIN; WHITE, 2005; NÓBREGA, 2009; WHITE, 2004), por meio da qual o aluno não somente não está apto como ele não tem, de base, hábitos relacionados a estudo para seguir na escola da forma como lhe é e será exigido. Do mesmo modo, esse item traz, também, o Julgamento de estima social (MARTIN; WHITE, 2005; NÓBREGA, 2009; WHITE, 2004), pois há o posicionamento de crítica à capacidade do aluno de permanecer no CEFET/RJ.

Nas linhas 9 e 10, o professor tenta afastar o direcionamento aos alunos "cotistas" sobre o que está dizendo ("eu nunca procurei saber quem é quem se alguém é cotista ou não"). Porém, segue em seu discurso da linha 10 à linha 13, ratificando a ideia já desenvolvida no excerto anterior (excerto 12) sobre a diferenciação cronológica entre antes e depois das cotas, por uma avaliação encaixada (LABOV, 1972) ("eu percebia alunos com essa dificuldade que tinha antes também mas era uma eles representavam menos na turma eles eram menos visíveis"). É possível perceber a utilização de itens que trazem, novamente, a nuance de validação estatística com o advérbio "menos" e que, por sua vez, marcam também a diferenciação cronológica supracitada.

Outra marca importante de construção de características específicas sobre os alunos de cotas é seguindo ainda a linha 13 ("eles eram engolidos por pelo processo"). Luciano utiliza a palavra "engolidos" para apontar o caminho, antes da política de cotas, que o antigo aluno passava quando apresentava qualquer problema que saísse dos altos padrões do CEFET/RJ. Eles eram engolidos pelo processo, metáfora que mostra que não havia qualquer possibilidade de um aluno que fosse diferente do esperado sobrevivesse academicamente na instituição.

Entendo, a partir disso, que o risco do aluno ser engolido diminui quando a política de cotas entra em ação, trazendo para a superfície visível a diversidade de alunos com os quais os docentes iriam trabalhar após a implantação da política de cotas. Aqui é exposta a força do poder da instituição e dos sistemas de coerência de meritocracia que sustentam tamanha assimetria. Há, também, neste ponto, a personificação de um "processo" que engole os alunos que não conseguem permanecer, não havendo exatamente, no discurso de Luciano, um sujeito agente desse verbo, transferindo a responsabilidade da não permanência do aluno a algo que não se sabe exatamente o que é.

Da linha 26 à linha 30, Luciano realiza a coda da narrativa, após a pequena avaliação (LABOV, 1972) que faz na linha anterior (L25). Ele conclui que a solução encontrada para atender às dificuldades dos novos alunos foi exatamente o que ele disse, no início de sua narrativa, não ter feito, que é modificar a metodologia e 
o currículo ${ }^{38}$ da disciplina. Cabe, também, atentar para o fato de que Luciano descreve uma série de atitudes que mostram o recuo dos docentes em sua forma de ensinar e sobre o conteúdo apresentado aos novos alunos. Assim, o novo aluno não teria a necessidade de ficar anotando e nem de ter muita atenção à aula (L29 e L30), atendendo às limitações esperadas de um aluno "cotista".

\subsection{1. Conclusões da seção}

As diferenças entre "nós" e "você" ficam marcadas através do que é benfeitoria e o que é ruim. "A gente" salva, se articula, muda a prática em prol dos alunos, tenta resgatar, reflete, é ainda desavisado, se preocupa. Já "você" marca a indeterminação do sujeito responsável por ações, como botar pra fora da escola, não selecionar os alunos da forma adequada, perceber os problemas que os "cotistas" causam, reprovar, não conseguir ler os trabalhos ilegíveis, ter alunos fracos e perceber características ruins.

Nos dados, há uma forte tendência à agência seletiva dos professores. Eles se excluem da agência quando há relatos de atividades ruins, descrições negativas sobre os alunos ou histórias pessimistas. Essa percepção se completa quando eles, então, se incluem de modo ativo quando as histórias contadas são histórias em que eles salvam alunos. Quando os docentes dizem "você", eles parecem referenciar os alunos e a suas ações, em especial as consideradas ruins, por estarem fora dos padrões esperados.

Já na utilização de "eles" x "a gente" / "nós", encontrei uma diferenciação explícita que distancia os falantes dos alunos "cotistas". É interessante que não vi somente essa característica no uso de "eles", mas entendi que também é uma forma de apresentar o aluno "cotista" como único e responsável pelo seu caminho escolar, seja ele exitoso ou fracassado. "Eles" que têm uma barreira interna, não conseguiram seguir em frente, são expulsos da escola (sem agente), têm deficiências, causam estranhamento (sem objeto), têm postura de vítima, vão ser

\footnotetext{
${ }^{38}$ Aqui utilizo o termo "currículo" de forma básica e até leviana, contrariando as teorias sobre o tema na área de educação. Faço isso porque não entendo como relevante explicar todo o aporte teórico que cerca as definições sobre currículo nesta tese. Desta forma, optei por utilizar o termo coadunando com o que o senso comum deposita na palavra "currículo", como reunião de tudo que se dá entre o ensino e a aprendizagem na escola, direcionando ao que comumente chamam de "matéria".
} 
"cuspidos"39 (sem agente), vêm com uma deficiência de base, repetem de ano, não sabem conversar. Mesmo para relatar caminhos positivos, também é apresentado um caminho solitário. "Eles" vão para frente, conseguem encarar de frente (sem objeto, é uma estrutura metafórica) e não abaixaram a cabeça.

Fica evidente, também, a transferência de responsabilidade pelo que é dito, com o uso de itens que afastam validações institucionais das falas dos docentes. Quando dizem "ainda não vi os números para confirmar o que vou dizer" ou "isso é a minha opinião" ou "não sei com os outros, mas na minha aula", os professores estão afastando a responsabilidade sobre tudo que irão dizer sobre as cotas e os alunos. Dessa forma, podem dizer o que quiserem sem ficarem expostos à pena pelo que emitiram.

Ainda, as anedotas são parte fundamental para que as construções sobre os alunos "cotistas" sejam elaboradas e expostas. Percebo que é através das histórias que os docentes contam que o que se espera do aluno é exposto. São histórias hiperbólicas, mas com grande valor de significado, tendo em vista que formam índices para estigmas sobre os alunos. Esses índices se estabelecem de modo não só a identificar os alunos, mas também de fortalecer e ratificar o sistema de coerência da meritocracia.

Parece que a construção exagerada das características, das ações, do que eles fazem, de como não sabem se comportar em sociedade ou de como não sabem ler, escrever ou fazer contas básicas faz parte de uma grande carga dramática nas narrativas. Entendo esta força dramática como uma busca, também, por validação do que os professores estão dizendo. Para que minha história tenha validade e para que as pessoas acreditem no que estou relatando, é preciso exagerar determinados elementos da história.

O que não é mensurável são os danos que essas histórias contadas podem trazer aos alunos a partir do momento em que são verbalizadas. Enquanto essas histórias viajam pela escola e pela sociedade, elas não são só discurso circulando, mas transmitem valores e expectativas e identificações sobre os alunos que constroem o Discurso sobre cotas. É preciso atentar, então, para a força ilocucionária que tem o discurso das anedotas. Para melhor ilustrar os resultados desta seção, apresento o Esquema 3:

\footnotetext{
${ }^{39}$ A narrativa onde aparece esta construção não foi adicionada ao capítulo de tese, mas considero relevante citá-la como exemplo do meu argumento de análise.
} 
Esquema 3: Relação entre os estigmas, narrativas e modos de realização discursiva.

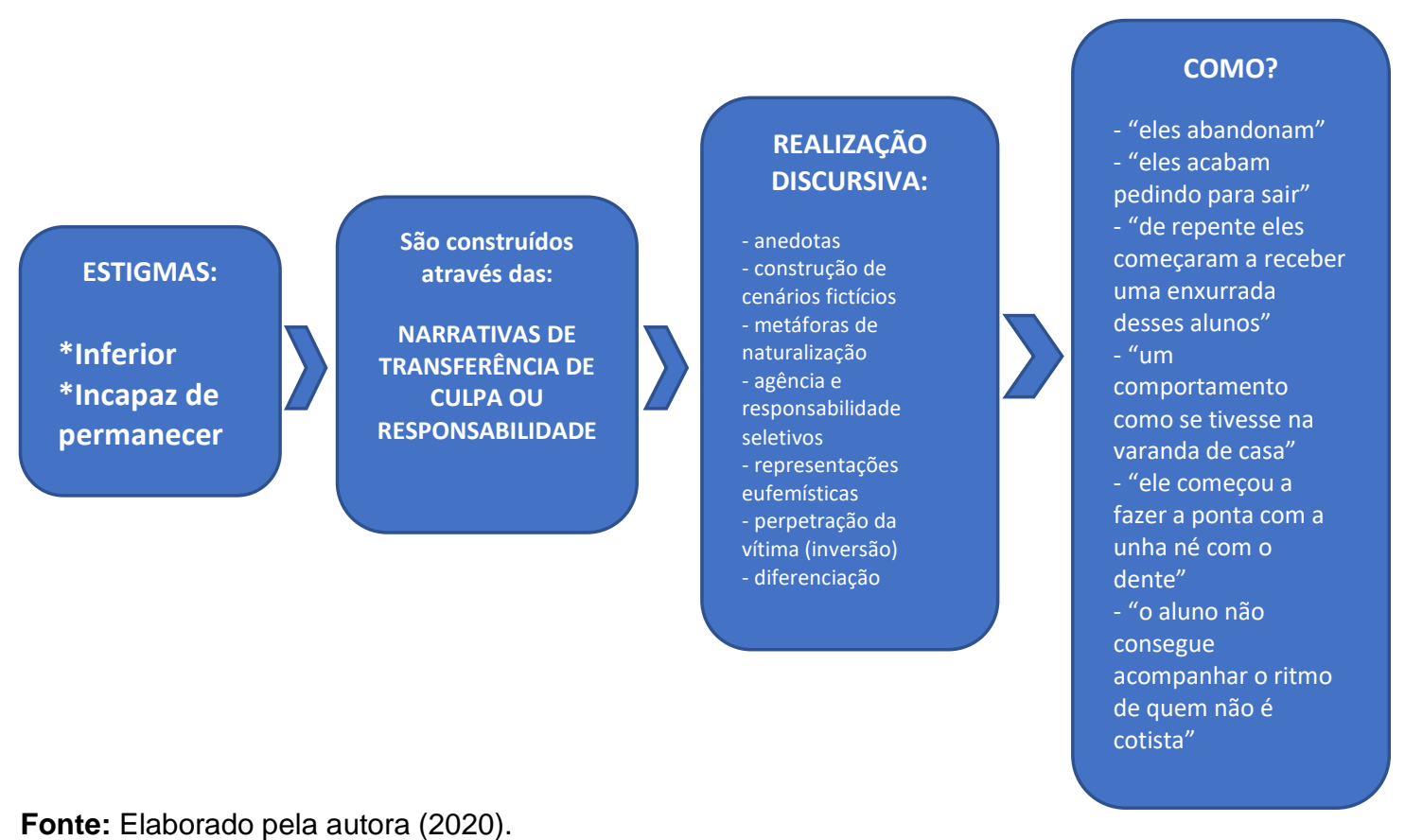

Fonte: Elaborado pela autora (2020).

Findada a discussão sobre as narrativas de transferência de culpas ou responsabilidades, parto para a análise das narrativas de trivialização das discriminações, apresentada na seção que se segue. Até aqui, entendemos quais são os estigmas que caracterizam os alunos que acessam o CEFET/RJ pela política de cotas. Apresentei como esses estigmas são construídos discursivamente pelas estratégias retóricas e das anedotas contadas pelos docentes. Agora, começo a caminhar para o outro lado que ajuda a construir essas características, que são os elementos históricos de validação do que é dito hoje sobre as cotas. Com isso, também inicio a análise das construções dos alunos "não cotistas", de modo a estabelecer as comparações que, por sua vez, estabilizam os estigmas diretos sobre cotas que já discuti nessa seção que se finda.

\section{2.}

\section{Narrativas de trivialização das discriminações}

Wodak et al. (2009, p. 36) descrevem a estratégia de trivialização mostrando o padrão de enfatizar semelhanças negativas ou características negativas em comum, ressaltando, por exemplo, diferenças entre o "antes" e o "agora" (WODAK 
et al., 2009, p. 36). O que ocorre é uma prescrição para descontinuar os caminhos da política de cotas. Há, então, um encaminhamento para a minimização das problemáticas que envolvem os alunos que acessam pela política, mediante eufemismos sugestivos.

Conforme mostrarei nas narrativas à frente nesta seção, os eufemismos usados nas narrativas sugerem coisas sobre os alunos. Coisas essas que entendo como mais índices sobre cotas e estigmas, cujos meios de realização no discurso aparecem pelas unidades que indicam diferenças, personificações e metáforas. Tais estigmas evidenciam índices de características positivas de alunos do antigo sistema (anterior às cotas), topos de valorização da experiência do professor como chancela de poder sobre a "verdade" que se fala e topos de salvador/docente - vítima/aluno "cotista", dominador - dominado.

Essas estratégias determinam as posições de poder não apenas sobre uso do Discurso sobre cotas, mas sobre a criação de índices que instanciam mais estigmas aos alunos, ao estabelecer o que é visto como verdade histórica e o que é "apenas" uma problemática pontual a ser transpassada. Para iniciar o caminho de análise que proponho nesta seção, trago mais uma narrativa de Pedro, no excerto 14. 
Excerto 14: "eles mesmos se punem, eles se jubilam"

\begin{tabular}{|c|c|c|}
\hline Pedro & $\begin{array}{l}1 \\
2 \\
3 \\
4 \\
5 \\
6\end{array}$ & $\begin{array}{l}\text { eles já passaram por isso no primeiro ano hh (.) então acho que } \\
\text { naturalmente isso acaba acontecendo (1.0) sabe (.) senão como } \\
\text { eu=como eu tenho costume de dizer eles abandonam (.) sabe (.) eu vejo } \\
\text { isso (.) é:.: se ele não se sentir tão à vontade eles não se sentem (.) né } \\
\text { por isso é que eu sou contra (.) a:: situação do jubilamento que eu } \\
\text { costumo dizer eles mesmos eles se punem eles se jubilam }\end{array}$ \\
\hline Allane & 7 & é um hum \\
\hline Pedro & 8 & porque eles não se sentem acolhidos pelo qrupo \\
\hline Allane & 9 & um hum \\
\hline Pedro & 10 & então (1.5) eles acabam (1.0) pedindo pra sair como dizem o termo \\
\hline Allane & 11 & é \\
\hline Pedro & $\begin{array}{l}12 \\
13 \\
14 \\
15 \\
16 \\
17 \\
18 \\
19\end{array}$ & $\begin{array}{l}\text { né eles não ficam (1.0) porque não se sentem à vontade a turma deles } \\
\text { passou (.) seguiu (.) e eles veem "poxa eu tô fora do grupo eu tô } \\
\text { desassociado disso" (.) então (.) eles não têm uma estrutura maturidade } \\
\text { não eu vou continuar o meu curso como na graduação quando você } \\
\text { repete uma disciplina e você.: continua tocando a sua vida (.) né eles } \\
\text { são muito novos pra isso eles se sentem (.) desagrupados e eu vejo que } \\
\text { eles acabam sain=eles preferem sair (2.0) é o que eu percebo assim } \\
\text { como uma média }\end{array}$ \\
\hline
\end{tabular}

\begin{tabular}{llll} 
Allane & 20 & é e a gente viu lá né no próprio condmet né em que a gente acabou \\
& 21 & vendo aquele dado lá rapidamente e a maioria é=é cota né \\
\hline Pedro & 22 & é cota infelizmente é cota \\
\hline Allane & 23 & então é se eles é infelizmente são são de cota \\
\hline & 24 & é (1.0) inclusive eu acho que:: (1.0) na pesquisa discente (.) havia (.) \\
& 25 & algo sobre essa pergunta (1.5) né (.) se=se ele já vivenciou se ele se \\
Pedro & 26 & sentiu:: né menosprezado se ele se como é=é=é alguma (.) alguma \\
& 27 & situação de racismo se ele visualizou eu me recordo (2.0) que eu não \\
& 28 & vi (.) uma resposta assim muito efetiva dos alunos sobre isso
\end{tabular}

Cabe ressaltar que essa narrativa já foi analisada sob a ótica de outras categorias trabalhadas na seção 5.1. Pedro parece se sentir à vontade de identificar os alunos "cotistas" como repetentes e traz a voz desses alunos para ratificar a suposta ausência de discriminação na instituição ("inclusive eu acho que na pesquisa discente havia algo sobre essa pergunta né se se ele já vivenciou se ele se sentiu né menosprezado se ele se como é é é alguma alguma situação de racismo se ele visualizou e eu me recordo que eu não vi uma resposta assim muito efetiva dos alunos sobre isso", L24 a L28). Deste modo, Pedro se afasta da avaliação sobre a percepção de que os alunos sofrem discriminação.

A estratégia de trivialização (WODAK et al., 2009, p. 36) vem deslegitimar as discriminações sofridas pelos alunos "cotistas". Penso que isso se conjugue com o discurso de que o aluno se expulsa sozinho da escola por não conseguir 
dar conta da instituição, o que indica que aquele, então, não é o local adequado a "este tipo de aluno", como já apontei na análise dessa narrativa no excerto 1.

Um dos meios pelos quais se realiza a trivialização é a minimização (WODAK et al., 2009, p. 36) que, por sua vez, se realiza discursivamente, diminuindo a dor dos diversos preconceitos que os alunos sofrem, afastando a segregação como problema. Minimizar a ponto de tornar até mesmo inexistentes os racismos, as discriminações e os assédios que os alunos "cotistas" sofrem é isentar-se de assumir como problema o discurso estigmatizante que circula na escola. Discursivamente, a estratégia de minimização aparece no excerto 14 das linhas 24 a 28, quando Pedro faz o movimento de trazer a pesquisa interna com os discentes para afirmar que eles mesmos dizem não se sentirem segregados.

A narrativa do excerto 15 é de Eduardo, que inicia sua história contando o caso de racismo que houve no CEFET/RJ e que teve grande repercussão nas mídias sociais e que já citei no capítulo 2 de contextualização desta tese.

\section{Excerto 15: "mas isso foi um caso pontual"}

1 bom (.) eu tive acesso né a:: aos problemas que surgiram (2.0) é::

2 mas grave foi aquele da (1.5) é (.) via internet né que=que houve

3 uma: (1.0) uma ofensa mútua (.) né (1.0) é:: não foi só de um lado né

4 (2.0) só que a interpretação foi unilateral né quer dizer pare=parecia

Eduardo 5 que a ofensa era=era só de prum lado né numa direção e não era

6 tem nas duas direções (2.0) e aí:: mas isso foi um caso pontual (.) e

7 num (.) num percebo isso como: até porque a:.: a escola tá muito

8 mesclada né (.) então ela:: ela:: é uma escola morena né não é mais

9 uma escola branca (.) então.: e cada dia mais

\begin{tabular}{|c|c|c|}
\hline Allane & 10 & já é visível né \\
\hline Eduardo & $\begin{array}{l}11 \\
12 \\
13 \\
14 \\
15 \\
16 \\
17 \\
18 \\
19 \\
20 \\
21 \\
22 \\
23 \\
24 \\
25 \\
26 \\
27 \\
28\end{array}$ & 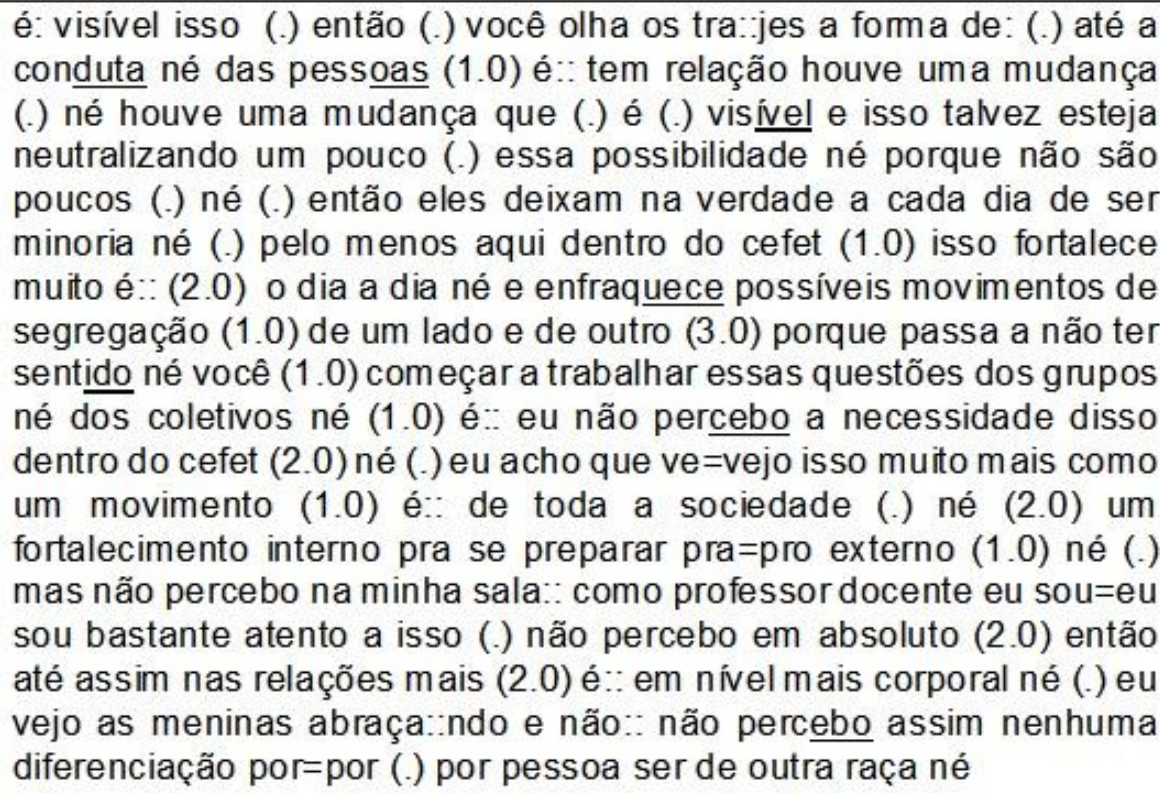 \\
\hline
\end{tabular}


A micronarrativa de Eduardo mitiga a gravidade que tem 0 caso $^{40}$ que ele conta, mas, ao mesmo tempo, o docente já emite a sua opinião sobre o ocorrido, deixando evidente que a situação de racismo foi, para ele, para os dois lados. $\mathrm{Na}$ ação complicadora, Eduardo não define a situação diretamente como racismo (L2 e L3). Ao contrário, delimita que foi um caso grave de "ofensa mútua" e ratifica o que diz quando reforça que o que foi unilateral foi a interpretação e não a ofensa. Segue logo para a avaliação de sua história, dizendo que parecia que a ofensa era só para uma direção, mas, para ele, era nas duas direções (branco para o negro e negro para o branco).

$\mathrm{Na}$ coda, Eduardo reforça que esse foi um caso pontual, retirando a possibilidade de discutirmos ou assumirmos outras muitas situações de discriminação que ocorrem no espaço escolar. Em forma de coda avaliativa, da linha 7 à linha 9, o professor avalia que a escola hoje está "mesclada". Ao dizer que "hoje" a escola não é mais branca, Eduardo delimita cronologicamente a diferenciação entre o CEFET/RJ anterior e posterior à política de cotas. E usando um direcionamento binário para caracterização dessa diferença, diz que a escola é morena e não mais branca. Essas delimitações dão abertura à emissão, de forma argumentativa após o término de sua narrativa, de sua opinião sobre racismo e coletivo negro não apenas dentro do CEFET/RJ como para a sociedade em geral.

Nas linhas 12 e 13, Eduardo traça cronologicamente uma das diferenças entre o antes e o agora, após política de cotas implantada, quando diz que "houve uma mudança visível". O item "mudança" já prevê um estado anterior diferente a algum estado atual, e como o docente cita os trajes e a forma de conduta e diz que é "visível", ele marca o que seria bom e ruim nessa troca de um estado a outro. Porém, verbaliza que a mudança serviu para neutralizar a possibilidade de haver situações de racismo na escola, tendo em vista que o negro passa a não mais ser minoria. Mesmo com a verbalização de que foi algo "bom", essa é mais uma marca de diferenciação cronológica entre o antes e o depois.

Percebo que da linha 19 à linha 22, Eduardo se coloca distante dos movimentos negros ao criticar sutilmente a necessidade de existência de grupos de resistência. Isso se dá após a elaboração de seu argumento sobre não haver mais minorias no CEFET. Nessas linhas, ele ainda invalida a importância do

\footnotetext{
40 Para melhor entendimento, vale lembrar sobre a história citada no capítulo 2 de contextualização desta tese. Uma aluna fez um post racista no facebook e reagiu também de forma racista aos comentários recebidos, inclusive direcionando ofensas e ameaças pessoais a uma colega negra. $\mathrm{O}$ caso chegou ao DEMET e lidamos da forma que descrevi no capítulo, culminando na reunião com alunos e o coletivo negro da escola.
} 
debate e luta contra o racismo na escola, com a ideia de que essa mudança já está ocorrendo em nível macrossocial. Sendo assim, para ele, não há a necessidade de "começar a trabalhar essas questões dos grupos, dos coletivos". Do mesmo modo, o professor não identifica situações de discriminação em sua sala de aula.

Nesse sentido, identifico também como avaliação o silenciamento, por parte do docente, do racismo e das discriminações que ocorrem no espaço escolar. Eduardo isenta pelo menos a sua sala de aula, construindo a ideia de que no espaço que ele atenta, e de certa forma controla, não há situações de racismo. $\mathrm{O}$ professor valida sua história com o item "absoluto" (L25) que intensifica seu discurso para frisar que não há vestígio algum de racismo em seu espaço. $\mathrm{E}$ na linha 27, também para validar sua opinião, Eduardo diz que vê "as meninas abraçando" e isso traz a ele a certeza de que não há diferenciação de tratamento por alguém ser de "outra raça".

A narrativa de Eduardo abre espaço para que ele siga seu discurso emitindo opinião sobre o racismo, inclusive justificando a ausência dele com ações que isentam as pessoas do racismo pelo senso comum. Abraçar o negro e ter um amigo negro são construções que ouvimos no dia a dia para que as pessoas se isentem da responsabilidade do racismo estrutural que existe não só na sociedade mas em todos nós. Essa ideia também está diretamente relacionada a Discursos racistas que se construíram pelo mito da democracia racial. Há de se atentar, ainda, para uma certa compreensão de racismo, que é por si mesma racista.

A tentativa de cuidar do que se fala quando o tema é o racismo fica evidente na própria escolha lexical do que os docentes estão falando. A micronarrativa de Jeremias, no excerto 16, mostra esse cuidado para a construção de sua ideia de diferenciação cronológica entre o antes e o agora da escola.

\section{Excerto 16: "as turmas estão mais coloridas"}

1 a gente via:: basicamente:: (.) falando em termos raciais (1.0) é:: que Jeremias 2 a gente tinha uma:: uma:: uma quantidade de alunos muito brancos

\begin{tabular}{clll} 
& 3 & né (.) \\
\hline Allane & 4 & é \\
\hline Jeremias & 5 & ou muito próximo do que seria o branco \\
\hline Allane & 6 & é \\
\hline \multirow{3}{*}{ Jeremias } & 7 & o que seria como que a gente pode classificar isso direito (.) e:: a gente \\
& 8 & hoje tem um grupo bastante heterogêneo as turmas estão mais \\
& 9 & colori:das
\end{tabular}


A narrativa de Jeremias não é canônica e ele já inicia sua pequena história na ação complicadora ("a gente via basicamente falando em termos raciais é que a gente tinha uma=uma=uma quantidade de alunos muito brancos né ou muito próximo do que seria o branco o que seria como que a gente pode classificar isso direito") definindo a diferença cronológica, usando o verbo no passado ("a gente via").

O professor modaliza o que vai dizer quando fala "em termos raciais", não direcionando a fala pontualmente ao negro, mas não encontra dificuldade em usar o termo "brancos" ("muito brancos", L2). Do mesmo modo, modaliza a variação de alunos não brancos na linha 5 ("ou muito próximo do que seria o branco"). O desconforto continua ao questionar, ao final de sua ação complicadora, na linha 7, "como que a gente pode classificar isso direito". Assim, ele deixa a dúvida sobre como classificar, isentando-se de qualquer uso incorreto dos termos. Dessa forma, ele demonstra, também, que entende o quão problemático pode ser verbalizar determinados termos diante das novas rupturas discursivas que a sociedade passa atualmente. Parece-me "medo" em utilizar as palavras "negro" ou "pardo".

Da linha 7 à linha 9 ("e a gente hoje tem um grupo bastante heterogêneo as turmas estão mais coloridas"), Jeremias realiza uma coda avaliativa, seguindo o padrão de mostrar a diferenciação cronológica entre antes das cotas e depois das cotas no CEFET/RJ. Nesse momento, assim como na narrativa de Eduardo, no excerto 15, a diferenciação é marcada pela "cor" dos alunos. Jeremias termina sua pequena narrativa relacionando a heterogeneidade das turmas com as cores, que se relacionam à raça no sentido de senso comum.

O professor usa o advérbio "bastante" para intensificar seu discurso e reforçar a heterogeneidade que relata. Do mesmo modo, usa outro item para intensificar e marcar a definição de que "hoje" (tempo cronológico atual) as turmas estão "mais" (intensificador - advérbio) coloridas. É interessante notar, mais uma vez, as evitações de Jeremias, que se esquiva de palavras que se relacionem à negritude, utilizando o termo "coloridas" para ilustrar a diversidade que se estabeleceu na escola após a política de cotas. Ao fim de sua narrativa, por contraposição, fica evidente que Jeremias estabelece que, no tempo anterior, possuía um público de alunos de determinada característica (branco), e o tempo atual os alunos se dividem em outras diversificadas características (branco, pardos, negros).

Para concluir a ilustração desse padrão de construção discursiva de diferenciação entre o antes e o agora, trago mais uma narrativa de Paloma (excerto 17), também não canônica e pequena, e um trecho de uma opinião que 
a professora emite, que não considero como narrativa, mas entendo como um ponto importante de sua entrevista.

\section{Excerto 17: "o aluno que eu recebo ele vem mudando"}

1 a gente tem u:m micro-ondas lá (1.0) aí eles esque:ntam e ficavam ali

2 então a gente no:ta que a escola empob=é financeiramente os jovens

3 estão mais pobres (.) então a escola vai ter que trabalhar um pouco isso

Paloma 4 (.) mas na hora eu achei que ia cair ma:.is do que caiu tá (.) porque (.)

5 assim (1.0) como é que eu vou te dizer (1.0) eu to e eu sou professora

6 do técnico há vinte e dois anos (.) tá (.) em vinte e dois anos eu notei (.)

7 que mudou o ensino (.) o aluno que eu rece:bo ele vem muda:.ndo

Paloma conta sobre um curso extraclasse oferecido pela sua coordenação (núcleo técnico) e como percebeu, a partir do curso, que o CEFET/RJ ainda não tem estrutura para receber alunos com necessidade financeira. Então, ela relata que os alunos tinham que permanecer na escola nos dois turnos, e isso trouxe a necessidade do almoço, e a escola não tem um espaço para alimentação, como um refeitório. Ela conta que os alunos comiam pelo chão dos corredores e inicia essa história na linha 1, resumindo a narrativa ("a gente tem um micro-ondas lá") e parte para a pequena ação complicadora, na mesma linha ("aí eles esquentam e ficavam ali").

$\mathrm{Na}$ avaliação (LABOV,1972) de sua narrativa, Paloma diz que nota que a escola empobreceu (L2), porém, interrompe a palavra "empobreceu" e refaz essa fala de modo eufêmico, na mesma linha ("é financeiramente os jovens estão mais pobres"). A sua pequena avaliação da narrativa abre espaço para uma coda avaliativa, através da qual ela expõe a expectativa sobre a "queda", sem dizer exatamente a qual queda ela se refere. Pressuponho que seja a queda da "qualidade" da escola ou a "qualidade" dos alunos e, sendo assim, Paloma realiza uma avaliação na dimensão de Julgamento de sanção social (MARTIN; WHITE, 2005; NÓBREGA, 2009; WHITE, 2004), já que há uma implicação quase que ilegal em mexer com a suposta qualidade do CEFET/RJ.

Da linha 5 à linha 7, Paloma traz o seu tempo de experiência na escola não só para demarcar cronologicamente a diferença entre o antes e o agora, mas para referendar a sua percepção de mudança. Porém, a sua compreensão de mudança vem de 22 anos para atualmente, o que deixa no ar a dúvida sobre em qual marco cronológico há a mudança que ela sinaliza com o verbo "mudou" ("eu notei que mudou", L6 e L7). Em que momento mudou? Não foi ao longo dos 22 anos, porque ela usaria só a forma verbal que usou ao final, na linha 7 ("ele vem mudando"). 
Nessa mesma linha, o item "mudou" determina um ponto específico que penso ser a entrada de alunos por cotas, já que no início de sua narrativa Paloma relata que a escola empobreceu após a entrada dos alunos pela política de cotas.

Já no segundo excerto de Paloma (18), ela marca as mudanças com outros itens, como "hoje" e "sempre". Nesse ponto da entrevista, eu pergunto à professora se ela se lembra ou se sabe de algum caso de discriminação na escola, mesmo que fora da sala de aula. Ela reponde que esses casos não existem, como pode ser visto no excerto abaixo.

Excerto 18: "com a cota a gente tem hoje mais afrodescendentes na sala"

\begin{tabular}{clll} 
Allane & $\mathbf{1}$ & mas você sabe que:: que já [aconteceu né] \\
\hline & 2 & & [não:.] (.) exi:.:ste mas é que(.) olha só allane \\
Paloma & 3 & até (1.0) óbvio (.) com a cota a gente tem hoje ma:is (.) afro \\
& $\mathbf{4}$ & descendentes na sala (.) mas é (.) o técnico do cefet sempre teve muito:.: \\
& $\mathbf{5}$ & $(1.0)$ mestiço vamos botar assim eu não sei como seria o temo corre:to
\end{tabular}

Paloma relaciona as cotas à negritude, demonstrando o alinhamento ao sistema de coerência de senso comum que envolve o Discurso sobre cotas no Brasil, sempre trazendo a polêmica da questão de cota racial. A professora demonstra, assim, desconhecimento da organização e distribuição de vagas com a implantação da política de cotas, tendo em vista que somente duas das quatro partes de cotas apresentam o componente raça como eliminatório.

Essa associação que Paloma faz muito diz sobre a relação direta entre a política de cotas e o que o senso comum fala e espera sobre o aluno "cotista". Além de todas as características sobre os alunos "cotistas" até agora construídas nas narrativas dos docentes, o aluno tem que ser, necessariamente, negro. Qualquer aluno branco que entrou para o CEFET/RJ pela política de cotas já possui um olhar diferenciado pela tentativa de "descartá-lo" como aluno que precisou da política. O mesmo ocorre com o aluno negro que entrou no CEFET/RJ nas vagas de ampla concorrência. Há nessa construção um Julgamento de sanção social (MARTIN; WHITE, 2005; NÓBREGA, 2009; WHITE, 2004), tendo em vista que as cotas, pelo sistema de coerência de senso comum, só podem ser oferecidas a alunos negros, retirando os brancos da possibilidade de serem pobres. Sendo assim, a política de cotas ser extensiva a brancos pobres não é legitimado tanto quanto seria se fosse apenas para negros pobres.

É possível, ainda, perceber o desconforto da docente em verbalizar palavras que apontam para a raça. Ela utiliza termos já debatidos e questionados, como 
"afrodescendentes" e "mestiço". Ela traz esses termos para informar que, como ela é professora do núcleo técnico e, consequentemente, lidou com os alunos de outros segmentos (concomitância externa e ensino subsequente), os alunos negros já frequentavam as salas de aula dessa modalidade e desse segmento de ensino.

Nas linhas 3 e 4, a docente traz as marcações cronológicas "hoje" e "sempre", que delimitam o espaço de tempo e o momento da mudança, que é a entrada da política de cotas no CEFET/RJ. Sendo assim, Paloma dá um ar de pormenorizar as diferenças existentes, tendo em vista que antes da política de cotas, na visão dela e na experiência com os outros segmentos de ensino, a diversidade racial já existia. Por esse motivo, demonstra não entender o motivo para a problematização do tema.

\subsection{1. Conclusões da seção}

A comparação cronológica encontrada nas narrativas dos docentes acaba, inevitavelmente, demarcando o "bom" e o "ruim". A partir do momento em que são descritas situações melhores da escola ou alunos melhores antigamente, pressuponho, por comparação, que o que há atualmente seja pior do que o que havia antes. Tal discurso de comparação entre tempos em minha pesquisa é um índice de deslegitimação da política de cotas. Mais do que isso, é um discurso que ajuda a trivializar qualquer luta relacionada à política, tendo em vista que torna a cota algo indefensável, já que é tão ruim diante da experiência que o CEFET/RJ já teve no passado.

Do mesmo modo, nesta seção, encontramos nas narrativas dos docentes, as formas verbais de construção que mais parecem uma procuração de plenos poderes pelo que se fala. Quando os professores trazem o peso do tempo em que trabalham na escola e "tudo" que sabem sobre a instituição e sobre os alunos, eles pegam para si o poder de selecionar e decidir o que é bom e o que é ruim. Isso é verbalizado no discurso que ratifica as características dos alunos que eles acham que faziam parte da manutenção da qualidade da escola.

Seguindo o caminho de análise, continuo junto às seções trazendo à reflexão e à discussão as construções encontradas em meus dados. Até agora apresentei como se constroem discursivamente as características e estigmas dos 
alunos "cotistas" (seção 5.1.) e, depois, na presente seção, como se constrói a trivialização das discriminações e das problemáticas que envolvem as cotas. Para melhor ilustrar os resultados, especificamente desta seção, apresento o Esquema 4:

Esquema 4: Relação entre os estigmas, narrativas e modos de realização discursiva.

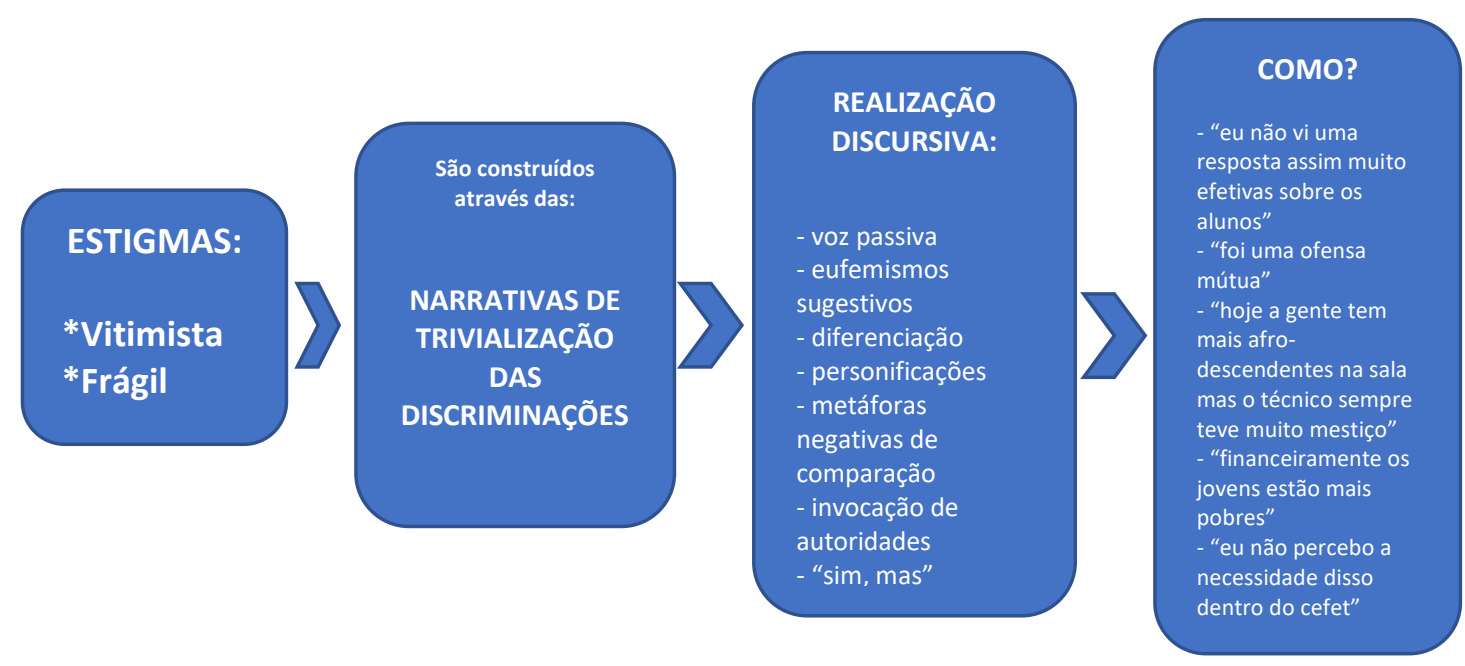

Fonte: Elaborado pela autora (2020).

Na próxima seção, discuto como acontece discursivamente a construção do engajamento entre os docentes, ou a demonstração disso, para que essa construção de política do fracasso seja justificada coletivamente, ganhando força a deslegitimação das cotas.

\section{3. \\ Narrativas de engajamento docente}

Nas narrativas de engajamento aparecem topos implícitos ou explícitos de comparação, incluindo a ideia de que "nós somos superiores a eles" que permeia o discurso de "estamos todos no mesmo barco". Mostrarei nas análises desta seção que os meios de realização (WODAK et al., 2009) ocorrem através da construção da singularidade.

Especificamente para as narrativas de engajamento coletivo, é possível identificar o sentimento de preocupações ou sofrimentos compartilhados. Isso ocorre por meio de comparações, que trazem ao foco determinada preocupação 
conjunta justificada por um nível nacional, e por meio de unificação de forças contra a perda da autonomia e unicidade.

Para melhor ilustrar, inicio trazendo o excerto 19, do docente Eduardo.

\section{Excerto 19: "a gente não vai conseguir resgatar"}

\begin{tabular}{|c|c|c|}
\hline & & \\
\hline & 1 & năo eu acho que.: e a a mınha sensação (.) por maıs que a ge \\
\hline & 2 & faça é uma sensação de impotência (1.0) diante do quadro (1.0) \\
\hline & 3 & porque esse quadro (.) ele é um quadro extremamente grave e que \\
\hline & 4 & na verdade é um acúmulo de deficiências (1.0) é um acúmulo de \\
\hline & 5 & danos (.) né (.) que são feitos ao longo de nove anos de fundamental \\
\hline & 6 & (.) e aí antes até na=na no no maternal no pré-matemal (.) quer dizer \\
\hline & 7 & na verdade é uma condição de família (.) e (.) é uma marca profunda \\
\hline & 8 & (.) né e:: (.) que a gente não vai conseguir resgatarvocê pode minorar \\
\hline duardo & 9 & um pouco (.) né (.) é:: mitigar o problema mas resolver o problema \\
\hline & 10 & eu acho eu a gente não pode colocar isso como meta (1.0) porque:: \\
\hline & 11 & a frustração vai ser enorme (2.0) porque você coloca um programa \\
\hline & 12 & de matemática onde você tem um número $x$ de inscrições (.) aí a \\
\hline & 13 & procura vai diminuindo vai diminuindo vai diminuindo e você vê (1.0) \\
\hline & 14 & que (2.0) é:: eu não tenho esses números mas é o resgate dessas \\
\hline & 15 & dessas mazelas (.) né (.) é:: ele é muito pequeno em compera =em \\
\hline & 16 & comparação ao esforço que está sendo feito pela instituição \\
\hline & 17 & ntendeu (1.0) então:.: é=é muito difícil \\
\hline
\end{tabular}

Da linha 1 à linha 11 do excerto 19, Eduardo expõe uma série de opiniões que entendo como sendo componentes de um grande resumo, com diversos itens de avaliação. A começar pela descrição de seu sentimento de "impotência" (L2) sobre a impossibilidade de que algo possa ser feito com tantos "danos", como dito pelo professor. Na linha 3, o docente usa o item de alta gradação "extremamente grave", descrevendo o quadro de "problemas" que a cota traz. Nesse ponto, Eduardo está referenciando as falhas do sistema educacional brasileiro como causa principal dos alunos de cota chegarem ao CEFET/RJ com tantas "deficiências" e "danos" acumulados (L4 e L5). Esses itens são avaliativos de Julgamento de estima social (MARTIN; WHITE, 2005; NÓBREGA, 2009; WHITE, 2004), pois têm posicionamento crítico por meio da crença de que os alunos têm "deficiências" e "danos" diversos acumulados, tornando o quadro "extremamente grave".

Depois, Eduardo transfere a culpa dos danos para a família, nas linhas 7 e 8 ("na verdade é uma condição de família e é uma marca profunda que a gente não vai conseguir resgatar"). Com esta afirmação, o professor cria mais um estigma para o aluno "cotista", que é o aluno que não possui estrutura familiar. Não apenas indicia esse estigma, mas diz que este é um dos motivos dos "danos" 
que a escola recebe ao receber os alunos, transferindo a culpa, finalmente, ao aluno. Eduardo utiliza o item "profunda" para qualificar a marca que a falta de estrutura familiar deixa no aluno (L7), o que traz a nuance de algo enraizando e, por isso, de difícil solução. Dessa forma, o docente realiza um Julgamento de estima social (MARTIN; WHITE, 2005; NÓBREGA, 2009; WHITE, 2004).

Mais uma vez o discurso de resgate aparece na linha 8, posicionando o docente e a escola como salvadores dos alunos ("a gente não vai conseguir resgatar"). Nessa pequena parte do excerto, antes mesmo de iniciar a narrativa, Eduardo traz dois índices sobre o aluno "cotista", reforçando não apenas as posições de poder onde os docentes e os alunos se encontram, mas também direcionando diretamente ao aluno, novamente, a culpa do possível insucesso da política de cotas, quando o caracteriza como um sujeito sem família estruturada. Esse é um Julgamento de sanção social (MARTIN; WHITE, 2005; NÓBREGA, 2009; WHITE, 2004), que avalia o aluno como abandonado e desestruturado em seu seio familiar.

Nas linhas 10 e 11 ("a gente não pode colocar isso como meta porque a frustração vai ser enorme"), o docente começa sua narrativa orientando a história com a construção da impossibilidade de solução do que vê como problema, quando diz que tentar resolver o problema pode trazer frustrações. "Isso" é o resumo de toda a sua opinião emitida antes de iniciar a narrativa, e também resume o discurso que analisei acima. Para dar ênfase à frustração, Eduardo utiliza o item de alta gradação "enorme" e logo segue para a sua pequena ação complicadora ("você coloca um programa de matemática ${ }^{41}$ onde você tem um número x de inscrições aí a procura vai diminuindo vai diminuindo vai diminuindo", L11 a L13).

$\mathrm{Na}$ ação complicadora, Eduardo enfatiza a história que está narrando sobre os alunos que até se interessam pelo programa de permanência matemática zero, porém, desistem no meio do caminho. Para reforçar em sua história a desistência, ele repete "vai diminuindo vai diminuindo vai diminuindo" (L13), trazendo um movimento prosódico importante que denota a gradação da evasão. É importante frisar novamente que o abandono está sendo atribuído ao aluno. Da linha 14 a 16, Eduardo realiza a avaliação (LABOV, 172), afirmando que o "resgate" é muito pequeno frente ao "esforço" (L16) que a instituição realiza com os alunos. Esta é uma avaliação de Julgamento de sanção social (MARTIN; WHITE, 2005;

${ }^{41} \mathrm{O}$ referido programa de matemática é uma das ações de política de permanência criadas pela coordenação pedagógica para a manutenção de todos os alunos com defasagens de conteúdo. É como uma aula de apoio, mas que resgata conteúdos do ensino fundamental e não atende aos conteúdos correntes do ano letivo (o que é realizado pelo programa de monitoria da disciplina). 
NÓBREGA, 2009; WHITE, 2004), já que há um gasto envolvido no investimento dos alunos e, com o sistema de coerência de senso comum de que esta vaga é doada ao aluno "cotista", há uma perda desse investimento financeiro com as desistências.

Nesse ponto da narrativa do professor, me parece que há o julgamento parecido com o que é feito quando se fala em "roubo de vagas". É como se alguém assimetricamente superior estivesse cedendo algo que não está sendo devidamente aproveitado por quem recebeu a "caridade". Na narrativa de Eduardo, isso é representado pelo "esforço que está sendo feito pela instituição" (L16). Como um investimento de baixo retorno, a política de cotas é colocada em questionamento diante do resultado que o docente acha que é desfavorável para a instituição. O próprio termo "em comparação" (L16) que Eduardo usa denota a relação investimento $x$ retorno.

Por fim, o professor realiza a sua coda avaliativa, que conclui resumindo o sentimento desse esforço todo descrito e do baixo retorno para a instituição, na linha 17 ("então é muito difícil"). O item de avaliação "difícil" é acentuado pelo item de alta gradação "muito", que enfatiza a luta difícil que os docentes e a instituição passam com a política de cotas e os alunos que a utilizam. Vale lembrar que todas essas construções fazem parte das narrativas de engajamento. Nesse momento, aparecem os topos de superioridade que justificam as afirmações de que docentes e escola são a salvação dos alunos "cotistas" e que, por essa posição superior, estes sim podem afirmar que é uma política fadada ao fracasso, porque, por mais que haja esforço, ele não é aproveitado de forma eficiente.

Para melhor expor a regularidade com que aparece a construção da má formação familiar como justificativa pelo julgamento de fracasso das cotas, trago agora no excerto 20 a narrativa de Luciano, que trata disso. 


\section{Excerto 20: "eles não tinham referência nenhuma em casa"}

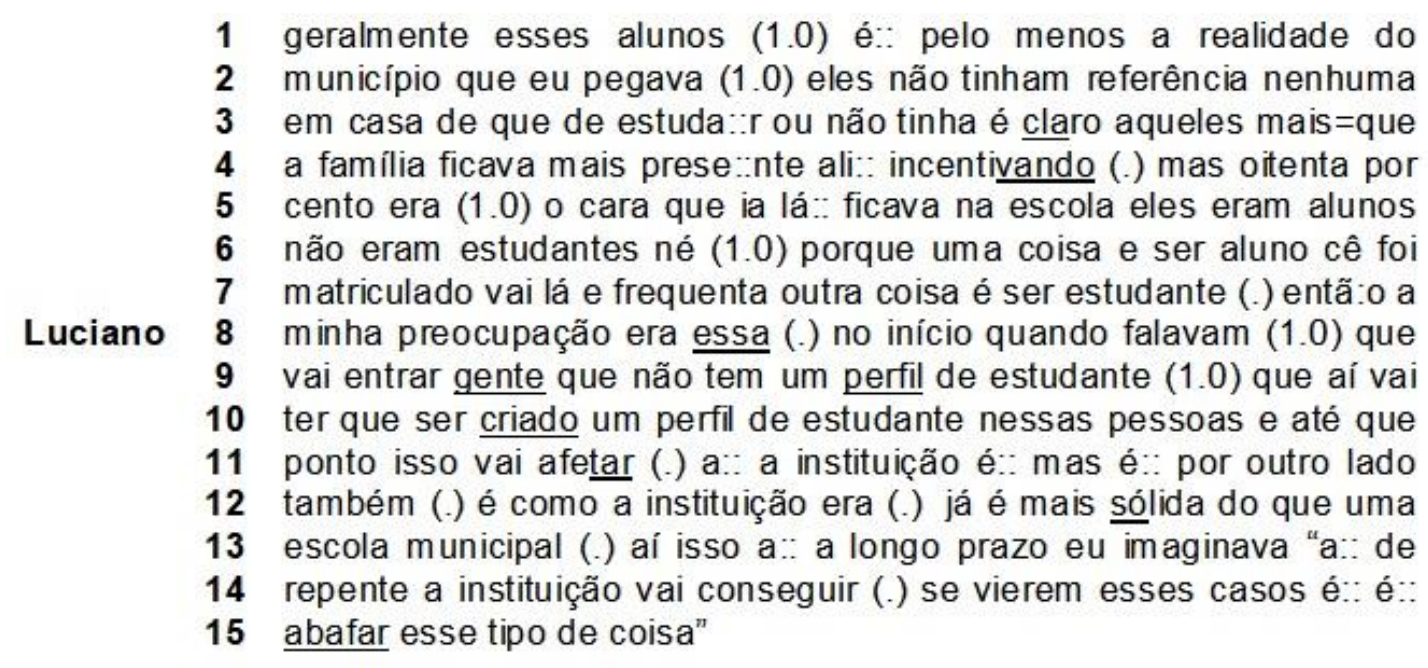

Luciano inicia o resumo de sua narrativa utilizando o topos de comparação (WODAK et al., 2009) quando, ao invés de discorrer sobre os alunos do CEFET/RJ, ele fala dos alunos do município, local onde trabalhou anteriormente. A pergunta que realizei ao docente foi como ele havia se sentido quando soube que iam entrar alunos oriundos da política de cotas no CEFET/RJ. Luciano começa, então, a falar sobre sua experiência no município, trazendo histórias do que viveu enquanto professor e desenhando uma comparação implícita do CEFET/RJ com o município. Todas as histórias eram ruins e demonstrando o comportamento desviante de determinado padrão esperado para alunos em sala de aula.

Luciano faz, então, uma relação direta entre sua experiência no município e o que ele esperava que fosse acontecer no CEFET/RJ, acreditando que esses mesmos alunos seriam os que entrariam pela política de cotas. Entendo que isso demonstre um padrão de expectativa do que os docentes estavam aguardando quando a nova política foi anunciada pelo edital. Essas comparações diretas mostram não apenas as expectativas, mas a construção do aluno "cotista" a partir de comportamentos ruins e experiências passadas pelo professor em outra instituição.

Nas linhas 2 e 3 ("eles não tinham referência nenhuma em casa do que estudar ou não"), o professor já inicia um Julgamento por estima social (MARTIN; WHITE, 2005; NÓBREGA, 2009; WHITE, 2004), construindo o imaginário de que são alunos que não têm pais ou responsáveis instruídos por educação formal. Em sua ação complicadora, Luciano modaliza a avaliação tentando amenizar a generalização sobre os alunos (L3 a L7), mas utiliza termos numéricos que 
reforçam a própria generalização. Ao mesmo tempo em que tenta amenizar o que diz, ele traz a porcentagem "oitenta porcento" para validar o que está dizendo e se fazer creditável.

Van Dijk (2017, p. 22) apresenta a ideia do que ele chama de "jogo de números" utilizado pela imprensa para trazer legitimação ao discurso que está sendo transmitido. O autor desenvolve o conceito explicando que é um "movimento retórico" que "sugere precisão e credibilidade estatística, mas que de fato é usado como um meio estratégico para enfatizar as qualidades negativas dos oponentes ou a situação atribuída para eles" (VAN DIJK, 2017, p. 22). No caso dessa narrativa, Luciano está descrevendo os alunos do município como desamparados, desmotivados e desinteressados e traz a porcentagem para legitimar o que está contando.

O professor realiza uma separação entre os significados de ser estudante e de ser aluno. O significado que ele dá ao aluno do município e ao "futuro cotista" do CEFET/RJ é o de aluno, que figura apenas a matrícula na secretaria. $O$ significado que resta ao estudante é o que frequenta e, consequentemente, se dedica de modo diferente do que ele havia citado sobre os alunos do município. Aos alunos, Luciano entrega o símbolo do abandono familiar, e essa expectativa sobra aos "cotistas".

Quando Luciano realiza a avaliação (LABOV, 1972) de sua narrativa, ele já inicia trazendo o sentimento que ele define como preocupação, quando da entrada de alunos no CEFET/RJ. Na linha 10, o professor usa o termo "criado" ("vai ter que ser criado um perfil de estudante nessas pessoas"), pressupondo que não há isso. A começar que ele se distancia dos alunos novos de cotas utilizando o item "nessas pessoas".

Partindo da ideia de que a palavra criar pressupõe a inexistência do que será criado, entendo que Luciano está dizendo efetivamente que os novos alunos "cotistas" não possuem perfil de estudante. E mais, a escola e ele, representativo dos docentes em sua narrativa, são os responsáveis por esse trabalho de criação. Nesse ponto fica evidente, então, o engajamento coletivo para que o "problema" seja tratado pelos docentes e pela escola, colocando ambos os partícipes como superiores aos "cotistas".

Luciano finaliza sua avaliação (LABOV, 1972) trazendo o termo "afetar", na linha 11 ("até que ponto isso vai afetar a instituição"). Vale, neste momento, trazer uma definição estrita do termo, que significa fazer com que alguém se sinta abalado com algo que não condiz com o "normal". Quando o professor diz que sua preocupação era a de que esse o aluno iria afetar a instituição, ele indicia o 
aluno "cotista" como quem abala um determinado sistema já estabelecido. Há nesse ponto um Julgamento por estima social (MARTIN; WHITE, 2005; NÓBREGA, 2009; WHITE, 2004), pois traz o aluno como causa de incômodo ou lesão ao status quo do CEFET/RJ.

Há a criação aqui, então, do índice de algo ruim contra o qual a instituição deverá unir forças para combater ou consertar. E consertar traz a ideia de que 0 aluno "cotista" deverá ser modificado para que se encaixe em algo já estabelecido. O aluno passa a ser, dessa forma, algo não somente a ser combatido, mas a ser modificado do errado para o certo, aos moldes de um aparente sistema imutável. Quem deve se modificar é o aluno e não a instituição. Na coda avaliativa de Luciano (L11 a L13), isso fica evidente logo no início ("como a instituição já é mais sólida do que uma escola municipal”, L12 e L13), quando o docente compara o CEFET/RJ com o sistema municipal de ensino, trazendo o valor de poder que ele atribui à escola.

O professor institui o CEFET/RJ de um poder tão forte que é óbvio que não é a escola que se modificará ao receber os alunos "cotistas". Tanto que, caso o aluno não consiga se encaixar nos moldes já existentes, ele será "abafado" (L15) pela escola. Atenção ao termo "abafar" utilizado por Luciano e a carga de poder que ele atribui à instituição que abafa "esse tipo de coisa" (L15). Ou seja, considerando todas as histórias não expostas nesse excerto, mas, que Luciano contou em momento anterior a esta narrativa, o CEFET/RJ jamais deixará que esses casos tomem lugar na escola. O item modal "eu imaginava", na linha 13 , mostra o baixo grau de comprometimento no discurso de Luciano (HALLIDAY, 1985).

A título de contextualização, Luciano conta que enfrentou alunos que traziam bombas para explodir no colégio municipal onde trabalhou e alunos que enfrentavam o docente em sala de aula, desrespeitando-o. Essas histórias estão em um artigo meu publicado em $2019^{42}$ e relatam as associações que o professor faz entre os alunos das escolas municipais com os alunos "cotistas" que entrariam no CEFET/RJ em 2013. Ou seja, os alunos do CEFET/RJ foram comparados a vândalos. Sem deixar de lado, também, a generalização que o docente faz sobre os alunos da rede municipal de ensino do Rio de Janeiro, é importante entender essa associação que Luciano faz que, por fim, criou a expectativa de

42 PEDROTTI, A. S. "Era um inferno": análise narrativa da construção discursiva da emoção do professor e suas reflexões avaliativas sobre os sistemas municipal e federal de ensino. Contraponto, v. 6, p. 22-39, 2019. 
comportamento sobre o aluno "cotista" do CEFET/RJ, que acaba por criar mais esse índice já discutido.

A narrativa de Luciano mostra a força ilocucionária desse estigma sobre o aluno "cotista" e o sentimento de coletividade para "combater" tudo de ruim que poderia vir quando da entrada deles no CEFET/RJ. No imaginário do docente, a instituição uniria forças, balizadas no forte poder que já possui, para que qualquer situação que fugisse à dita normalidade da escola fosse exterminada. Esse tipo de sentimento, essas expectativas que indiciam o aluno como vândalo, fazem parte da estratégia de engajamento para combater a política de cotas. Assim, não só os alunos são desmoralizados, mas são projetados problemas graves de conduta que trariam conturbações sérias à escola no imaginário dos docentes.

Unir forças para não deixar determinados casos evoluírem no CEFET/RJ permeou as expectativas fantasiosas, de forma que os docentes pudessem, também, se construir como elementos fundamentais nessa "luta". E, dessa forma, retorna novamente a imagem de que, engajados, os professores podem salvar a instituição e os alunos "cotistas" de tudo de ruim que poderia vir matriculado junto com os alunos da política de cotas. As duas narrativas da professora Ana, que trago nos excertos 21 e 22 a seguir, contam mais um pouco sobre esse engajamento.

\section{Excerto 21: "a gente se articula de todas as formas"}

1 aí eu to falando a gente se articula de todas as formas que eu pude eu=eu

2 eu me articulei é:: pra dar toda assistência do mundo pra=pra essa garotada Ana 3 (.) e procurando também (.) avaliações (1.0) é (.) onde avaliações muito em 4 grupo (.) onde assim se um aluno fosse mal todos iriam também (1.0) então 5 era uma forma que eu vi (.) dos garotos mais preparados (.) cuidarem (.) dos 6 menos preparados então acho que foi mais ou menos por aí

Ana inicia sua narrativa resumindo (L1) com determinada certeza de que fez de tudo o que podia ter feito para ajudar os alunos "cotistas", quando ela fala que "a gente se articula de todas as formas". "Todas as formas" indica que não há mais o que ser realizado, sem negociação, e mostra, também, a ação coletiva com o item "a gente". Isso corrobora não apenas a estratégia já discutida na seção anterior sobre o uso desse item em momentos em que a escola e os docentes fazem algo bom pelos alunos, mas também com o engajamento entre docentes e escola. No resumo ("eu me articulei para dar toda assistência do mundo pra essa garotada", L2 e L3), além de se afastar dos alunos com o item "essa garotada", 
Ana novamente traz o término de opções possíveis para a permanência exitosa do aluno no CEFET/RJ.

$\mathrm{Na}$ ação complicadora, da linha 3 à linha 5, Ana descreve suas ações com o objetivo de auxiliar os alunos, trazendo a metodologia de avaliações que realizou. Nesse ponto da narrativa, Ana traz a expectativa de que os alunos "cotistas" iriam mal nas avaliações, mas, como eram aplicadas e feitas em grupos, todos os alunos também iriam mal. Mas ela vê essa metodologia como positiva e como uma forma de os alunos "não cotistas" "cuidarem" dos menos preparados "cotistas". Mais um índice, então, é criado para o aluno de cotas, o de que precisa ser cuidado de forma diferenciada e especial e, nesse momento, não somente pelos docentes e pela instituição, mas pelos próprios alunos colegas de classe. Os itens modais "assim" (L4) e "acho" (L6) mostram o baixo grau de comprometimento (HALLIDAY, 1985) de Ana.

Entendo isso com uma fragilidade atribuída ao aluno de cotas que, de certa forma, completa o sentido dado a ele de aluno abandonado e que sequer possui estrutura familiar. Vejo como um sujeito que não tem ninguém em sua vida e que, necessariamente, precisa do CEFET/RJ, dos docentes e, agora, de seus colegas de classe "não cotistas" para que consiga ter algum cuidado e, com isso, alguma evolução em seu processo escolar. Tudo depende do engajamento docente que une forças para que o aluno não esteja desamparado.

Veja, isso tudo para que o aluno que entra pela política de cotas não atrapalhe o processo em andamento de uma escola com qualidade exemplar para a sociedade. Dessa forma, o engajamento para amparar as situações fantasiosas esperadas pela comunidade escolar vem para consertar uma política que, após tantas histórias catastróficas, não dá certo, segundo as narrativas. Mas, como a escola é obrigada por lei a aplicar a política de cotas, resta o engajamento, para que algo que tem tudo para dar errado tenha alguma chance de dar certo.

A coda de Ana não diz muito, mas finda sua narrativa com um ar de que a história toda não foi contada, mas é "mais ou menos por aí" (L6). Já em sua segunda narrativa, no excerto 22 , Ana deixa mais evidente que considera a política de cotas um problema e detalha mais o engajamento coletivo para resolver esse problema. 


\section{Excerto 22: "a gente se une não é na felicidade, eu acho que é no desespero"}

1 sim mas eu acho: (.) a gente veio (.) tem dados aí né em várias reuniões já

2 foram mostrados da: dos pra gente a gente se a acho que se articulou

3 muito a gente conse=é colocou é $:$ mais pessoas capacida: de pra dar um

4 supo::.te psicológico é:: uma ass=assistência social me::smo (.) a gente

5 conversou muito mais porque a gente se une (1.0) não é na felicidade eu

6 acho que é no desespero (1.0) né quando a gente tá lá por exemplo na

7 coordenação de fí:.sica tava todo mundo desespera:do po vamo sentar

8 vamo ver vamo ver junto que que a gente pode fazer (1.0) e aí entra a

Ana

9 coordenação de física com a coordenação de química com a matemática

10 que daqui a pouco com a biologia daqui a pouco uma reunião a gente tá

11 se articulando vamo colocar mais monitores vamo fazer isso vamo fazer

12 aquilo (1.0) então acho que a escola cresceu cara eu fiquei eu vi=vi as as

13 pessoas assim mais unidas dialogando mais pra resolver vamos colocar

14 entre aspas um=um problema que nos apareceu (1.0) e (2.0) bom eu acho

15 que (.) que se esperar o momento ce::rto o momento ideal pra que (.) ah

16 pessoal fala né "vamos esperar vamo primeiro trabalhar a educação infantil

17 e (.) fundamental pra daí:. o cara chegar no ensino médio preparado" é

18 besteira isso (.)

Dentro da narrativa de Ana, do excerto 22 , há uma pequena narrativa que se encaixa no resumo e na orientação do que chamarei de narrativa maior. Entendo que, da linha 1 à linha 6, há o resumo e a orientação da narrativa maior de Ana, mas contém uma pequena ação complicadora da linha 2 à linha 5 ("a gente acho que se articulou muito a gente colocou mais pessoas capacitadas para dar um suporte psicológico é uma assistência social mesmo, a gente conversou muito"). Há uma coda avaliativa encaixada nesse ponto nas linhas 5 e 6 (“a gente se une não é na felicidade eu acho que é no desespero").

Analisando essa pequena narrativa encaixada à grande narrativa de Ana, é importante atentar para o que discutimos nesta seção, que é o engajamento docente marcado por Ana pelos itens "a gente", que se repete diversas vezes nesse pequeno trecho. A docente relata que houve uma articulação entre profissionais capacitados, e entendo que isso inclui ela mesma, com atendimentos psicológicos e de assistência social. Ela inclui, também, "muita" conversa, que entendo que seja entre os profissionais, o que desenha um cenário de todos juntos discutindo e encontrando formas de perpassar por esse "problema".

Vale atentar, também, para o item "muito" que intensifica a articulação e deixa evidente essa força conjunta de trabalho e engajamento. A pequena coda avaliativa de Ana mostra esse movimento de união com o item "une" (L5), completando a ideia de que a situação da política de cotas no CEFET/RJ é definida como desespero (L6), mostrando como o impacto é sempre hiperbólico. No campo semântico do Afeto (MARTIN; WHITE, 2005; NÓBREGA, 2009; 
WHITE, 2004), há uma avaliação sobre a emoção de Ana, expressando insegurança por intermédio do adjetivo substantivado "desespero" (L6). Como supracitei, essa pequena narrativa faz parte do resumo da grande narrativa de Ana, que inicia sua ação complicadora, então, na linha 6, dando o exemplo da coordenação de sua disciplina.

Então, retornando à grande narrativa, na orientação (L1 e L2), Ana inicia trazendo uma validação externa ao que vai dizer, que são os dados que foram apresentados nas reuniões internas. Para dar força ao seu discurso, Ana utiliza o item "várias" (L1) para pontuar que não foi um momento único, mas em vários momentos dados foram apresentados, comprovando o que ela está por dizer. Quando ela chega ao resumo ("a gente se a acho que se articulou muito a gente conse=é colocou é $\mathrm{m}=$ mais pessoas capacidade pra dar um suporte psicológico é $\mathrm{ma}=\mathrm{uma}$ ass=assistência social mesmo a gente conversou muito mais porque a gente se une não é na felicidade eu acho que é no desespero né", L2 a L6), esse sentimento de unificação é manifestadamente demostrado pela quantidade de vezes que Ana utiliza o item "a gente". O item "acho", que segue a ideia de que "a gente se articulou", é um modal de baixa intensidade (HALLIDAY, 1985).

Corroborando com o que discuti na seção 5.1., o item "a gente" vem para descrever em forma de gradação tudo de bom que foi feito pela instituição, representada por docentes e equipes pedagógicas. "A gente" colocou mais pessoas capacitadas, "a gente" deu suporte psicológico, "a gente" conversou muito (muito - intensificador) demonstram o esforço coletivo para que o "problema" fosse amenizado e solucionado.

Nesse ponto da narrativa, fica notório não apenas sua avaliação de que as cotas são um "desespero", mas também que é nesse momento que acontece, para ela, a união entre os docentes da escola para solucionar o problema. Por oposição, a política de cotas e a entrada dos novos alunos por intermédio dela não é o sentimento de felicidade, termo que ela usa para montar o contraste entre a felicidade e o desespero em sua construção frasal.

A ação complicadora inicia com Ana contando que em sua coordenação de disciplina estavam todos desesperados (L6 e L7). Novamente, ela traz o significado de desespero para projetar o sentimento que os novos alunos causaram nos docentes, entrando na dimensão do Afeto (MARTIN; WHITE, 2005; NÓBREGA, 2009; WHITE, 2004). Ela desenvolve a ação complicadora trazendo itens que apontam para a estratégia de engajamento, como "vamos sentar" (L7), "a gente" (L8 e L10), "reunião" (L10), "articulando" (L11), "vamos colocar" (L11), "vamos fazer" (L11), mostrando muita agência da parte deles. 
Ainda como reforço dessa estratégia, Ana traz uma espécie de lista de coordenações de disciplina que poderiam se articular em reuniões, para que as forças fossem unidas para repensar o problema. Em sua história, ela constrói uma montagem escalada das coordenações, mostrando um movimento de união gradativa entre os colegiados do CEFET/RJ ("aí entra a coordenação de física com a coordenação de química, com a matemática que daqui a pouco com a biologia", L8 a L10).

Da linha 12 à linha 14 ("então acho que a escola cresceu cara eu fiquei eu vi as pessoas assim mais unidas dialogando mais para resolver vamos colocar entre aspas um problema que nos apareceu"), Ana realiza a avaliação (LABOV, 1972). É nesse ponto que Ana evidencia que a política de cotas e os alunos novos são um problema. Mesmo escolhendo modalizar o que diz, através da verbalização de que o que irá dizer deve ter aspas, a professora não deixa de dizer que é um problema. Assim, há uma avaliação direta de sanção social (MARTIN; WHITE, 2005; NÓBREGA, 2009; WHITE, 2004), quando o discurso dela indica que a política trouxe um problema para as bases "normais" e de "excelência" do CEFET/RJ, prejudicando o andamento de algo que não era problemático antes das cotas.

Dessa forma, para a docente, como solucionar um problema, senão pela união na coletividade, considerando que é por meio desse engajamento que o poder se estabelece para o "combate" ao problema? Mesmo que no discurso isso esteja travestido de soluções benéficas, isso não deixa de ser o poder institucional sendo construído, ajuntado e reforçado para que fique mais forte. Assim, aparece a estratégia de engajamento docente, para que haja a manutenção do poder já estabelecido no CEFET/RJ, fortalecendo a assimetria entre os alunos e os docentes e conservando a atualização do sistema de coerência sobre os problemas da política de cotas.

Vale ressaltar que a docente também utiliza o termo "mais" unidas (L13) para descrever que as pessoas modificaram determinado estado após a política de cotas. Essa formação define e delimita cronologicamente algo que antes das cotas não estava estabelecido, mas após as cotas as pessoas ficaram "mais unidas". Por oposição, antes das cotas não havia a união, ou a necessidade de unirem-se, mas após as cotas esse estado de individualidade se modifica, trazendo a necessidade de engajamento para resolver o problema que "nos apareceu".

É interessante, também, perceber que Ana diz que o problema "nos apareceu", o que indica que para ela não foi algo escolhido, mas surgido. O que aparece rompe com algo já assentado e não há a possibilidade de aceitação ou 
não do que surge rompendo. De fato, a Lei de Cotas (BRASIL, 2012) apenas foi atendida no CEFET/RJ quando se tornou obrigatória e mandatória após a consulta realizada pela escola (para relembrar, sugiro retornar ao capítulo 2 , onde descrevo o contexto da entrada da política de cotas no CEFET/RJ). Tendo sido mandatória, não houve possibilidade de não atendimento à legislação. E isso aparece de forma evidente no discurso da professora Ana, quando ela diz que o problema "nos apareceu". É interessante notar como o lastro histórico está presente nas narrativas sobre cotas.

Quando Ana inicia a coda de sua narrativa, na linha 14, ela faz menção ao pensamento de senso comum sobre o "erro" da política de cotas que encobre o problema maior, que é a reestruturação da educação em nível fundamental. Nesse ponto, a professora faz uma crítica a esse pensamento, crítica essa que apenas fica evidente ao final de sua coda, quando lança do item de avaliação "besteira" (L18). Ali ela delimita que se alinha à política de cotas, discordando de que ela não possa existir enquanto não forem mexidas nas bases mais fundamentais da educação brasileira. O item de modalização "eu acho", na linha 14, que dá a introdução ao que ela vai dizer nesta coda, expõe o baixo grau de comprometimento da docente (HALLIDAY, 1985).

E com a narrativa de Jeremias, exposta no excerto 23, caminho para a finalização de como as narrativas de engajamento são construídas pelos docentes. Jeremias fala sobre como a sua coordenação pensou a distribuição de professores por turmas para quando os novos alunos que acessaram o CEFET/RJ pela política de cotas chegassem.

\section{Excerto 23: "essas preocupações a gente teve"}

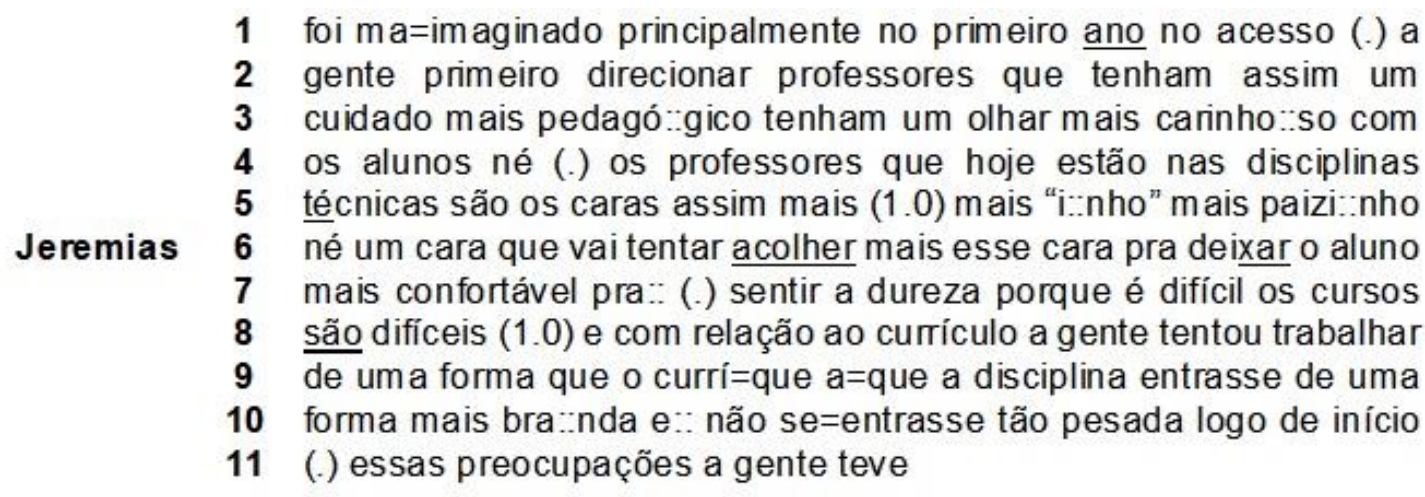

A pequena orientação de sua narrativa apenas direciona o entendimento de que a organização pensada foi exatamente focada nos alunos de cotas, tendo em vista que foi no primeiro ano que eles estariam em 2013. Ele deixa evidente que 
é pelos alunos "cotistas" que tudo que ele vai relatar foi pensado, exatamente porque no segundo, terceiro ou quarto anos não haveria "cotista" ainda. Então, na linha 1, isso fica explícito quando ele diz que "foi imaginado principalmente no primeiro ano no acesso". Jeremias utiliza o item modal de baixa intensidade "assim" repetido nas linhas 2 e 5.

Jeremias inicia a ação complicadora de sua narrativa contando como foi pensada e feita essa organização nova (L2 a L10) para os "cotistas". O professor aponta para o "cuidado" (L3) que a coordenação teve em direcionar os docentes mais "inho" (L5) às turmas de primeiro ano e, assim, conforme já relacionado acima, aos alunos "cotistas". Aqui Jeremias mostra o posicionamento da coordenação de sua disciplina sobre a necessidade de acolhimento aos alunos (L6), o que traz a ideia de fragilidade dos alunos "cotistas". Esse é um Julgamento por estima social (MARTIN; WHITE, 2005; NÓBREGA, 2009; WHITE, 2004), já que há uma avaliação moral sob a crença sobre a capacidade do aluno "cotista" no CEFET/RJ.

Do mesmo modo, é na ação complicadora ainda que Jeremias constrói o poder da instituição em "ajustar" o aluno para que ele consiga passar pela disciplina de forma mais "branda" (L10). Isso indica, novamente, o estado imutável de exigência como o CEFET/RJ é construído quando da entrada dos alunos "cotistas". Aos alunos apenas resta adaptarem-se ao que já existe secularmente, com o respaldo e as mãos do poder que a instituição tem. Aos alunos resta estar "mais confortável" (L7) para "sentir a dureza" (L7) porque a escola é "difícil" (L7 e 8). E, portanto, resta à escola o poder de acolher o aluno para que ele fique mais confortável, já que é o aluno que deve se adaptar e não a escola modificar-se.

Os itens diminutivos que Jeremias utiliza em sua narrativa também são indicativos da trivialidade com que ele trata a política de cotas e os alunos. O diminutivo não tem significado apenas para definição sintática da palavra utilizada, que nesse caso está na linha 5 ("os caras assim mais 'inho', mais paizinho"). O diminutivo também é significado do quanto ele reduz a importância da política de cotas nesse contexto relatado. Aos alunos "cotistas" são direcionados os professores mais "fracos", que fogem à regra esperada de exigência do CEFET/RJ. Por experiência autoetnográfica, quase consigo ouvir que esses docentes são os professores que passam direto os alunos, distribuindo pontos e avaliações moderadas.

Jeremias termina sua pequena narrativa realizando a coda na linha 11, indicando que essas foram as preocupações que o seu colegiado teve na época em que a política de cotas foi instituída no CEFET/RJ. O item "a gente" (L11) 
aparece para revelar o sentimento de engajamento da comunidade para solucionar o "problema". Assim como nas outras narrativas analisadas nesta seção, o discurso de Jeremias não foge ao padrão de construção retórica de engajamento para construção de estigmas sobre cotas.

\subsection{1. Conclusões da seção}

Para o suporte discursivo da estratégia de engajamento, a ideia de unificar forças inclui ratificar o esforço coletivo, mesmo que não exitoso, em melhorar ou consertar danos, como se pode ver nas narrativas analisadas. Há a constante demonstração do engajamento na comunidade escolar, evidenciando o que se quer evidenciar, que é a ideia de que "estamos fazendo o máximo que podemos" mas não está dando certo. Não somente porque a política vem com falhas, mas, principalmente, porque os alunos não conseguem usufruir do que lhes é dado. Dado no sentido de oferecido como caridade, conforme já discuti nesta seção.

Por vezes, a construção discursiva de bases ruins, tanto escolares quanto familiares, justifica o não aproveitamento por parte dos alunos a todo o trabalho que a escola despende para o seu desenvolvimento. Por outras, o próprio aluno é responsabilizado por não querer evoluir ou não querer prosseguir com os mecanismos caridosos que a escola oferece aos alunos. Não há qualquer reflexão sobre o quanto as políticas internas precisam ser revistas, aprimoradas ou adaptadas à realidade dos novos alunos e dos novos sistemas curriculares em si. O fracasso é sempre atribuído inteiramente aos alunos.

Para reforçar que o problema está com "eles" e não com "nós", os docentes utilizaram em suas narrativas itens de engajamento. Assim, não é somente a palavra de quem está narrando determinada história, mas há a validação de outras vozes do coletivo escolar, quando se convoca o "nós". O mesmo para as histórias narradas que constroem a escola como salvadora dos alunos. Esse é também um movimento de engajamento, a partir do pressuposto de que se a escola convoca políticas internas de permanência para "consertar" os "danos" causados pelas cotas, há o suposto sentimento maior de preocupação coletiva por um bem único, que é o CEFET/RJ. Para melhor ilustrar os resultados desta seção, apresento o Esquema 5: 
Esquema 5: Relação entre os estigmas, narrativas e modos de realização discursiva.

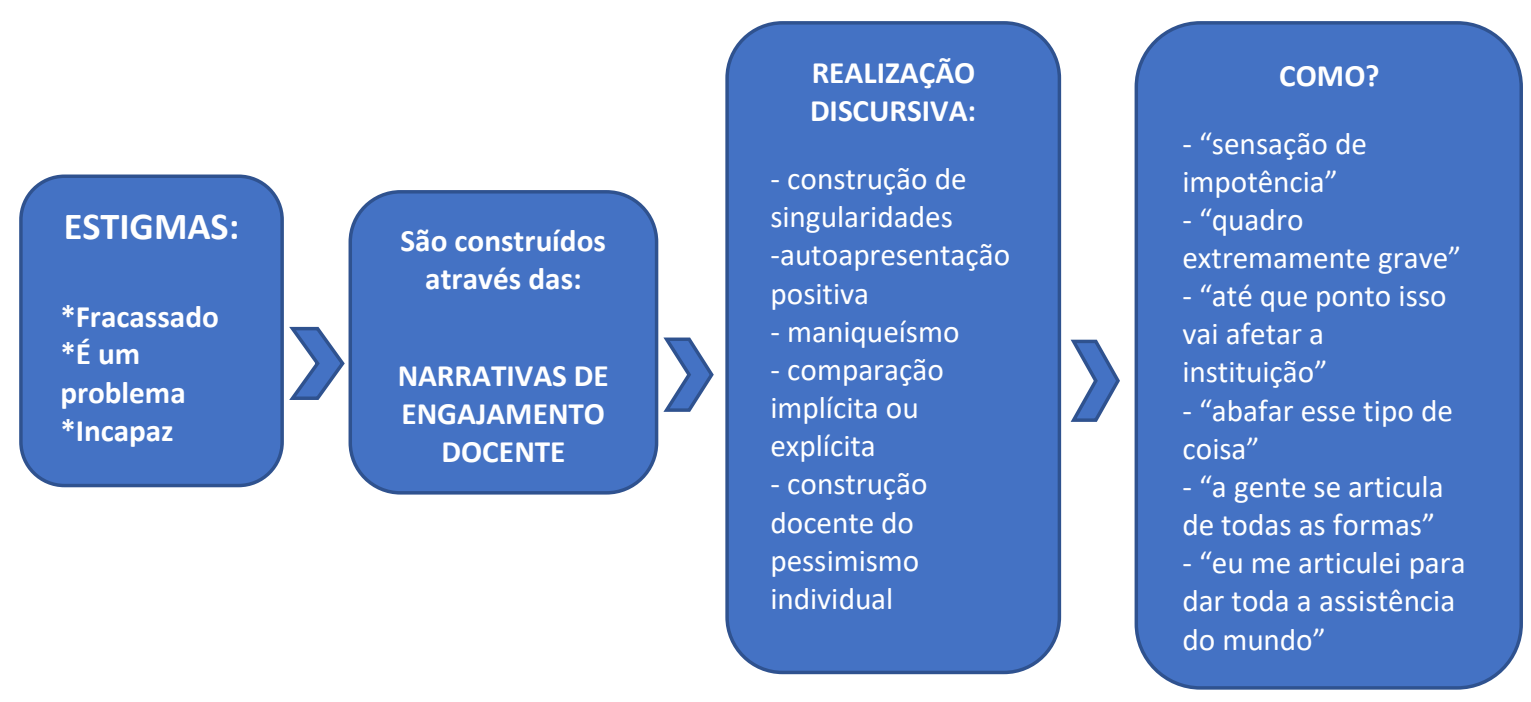

Fonte: Elaborado pela autora (2020).

Após entender como os docentes mostram a estratégia de engajamento em suas narrativas para se autoprojetarem positivamente e defenderem a instituição, analiso na próxima seção (5.4.) como histórias de conservação do velho modelo anterior às cotas criam estigmas de desordem do status quo do CEFET/RJ.

\section{4 . \\ Narrativas de conservação do velho modelo}

Para a construção dos estigmas sobre os alunos que acessam o CEFET/RJ pela política de cotas, continuo a análise gradativa de como os estigmas são construídos discursivamente. Após entender as construções de características dos alunos "cotistas" e as autoconstruções dos docentes e da instituição pela transferência de culpa ou responsabilidade, bem como compreender a trivialização das problemáticas sobre cotas e como se dá a estratégia dos discursos de engajamento docente para a construção desses estigmas, agora busco entender a construção da estratégia de conservação do velho modelo.

Com a estratégia de conservação do velho modelo, chego ao ponto da tese em que começo a analisar como se dão discursivamente as construções que 
direcionam à defesa de sistemas de coerência que perpetuam o Discurso de que a política de cotas é um "desastre" para a sociedade brasileira. Essa construção retórica se realiza por meio, principalmente, da negação da necessidade de mudança política, como veremos nesta seção. O topos central das narrativas é o sofrimento e o que há de ruim por culpa das cotas, por meio de um cenário caótico e desfavorável (WODAK et al., 2009).

Os excertos que apresento nesta seção não serão todos de narrativas, como proponho em meus objetivos específicos de tese, mas considerei importantes para analisar o discurso construído sobre cotas e sobre a estratégia de dizer que é uma política que não dará certo. Para iniciar, trago a narrativa do professor Eduardo, que mostra os julgamentos sobre as cotas com itens de avaliação como "erro", excerto 24.

\title{
Excerto 24: "eu acho que a política de cotas como política é um fracasso"
}

\begin{abstract}
1 então eu=eu=eu acho que :.: que :a política de cotas como política é Eduardo 2 um fracasso (2.0) como política é um fracasso (2.0) se a gente analisar 3 (.) com um olhar de economistas né números
\end{abstract}

O docente mostra a transferência de responsabilidade sobre o que ele fala, na linha 3, ao dizer que essa opinião que ele emite parte de um olhar de economistas. Isso ocorre porque, teoricamente, um economista pode não saber sobre educação, enquanto resta apenas aos educadores ou profissionais diretos da área a opinião legitimada sobre as cotas ou processos escolares, já que as cotas se inserem na escola. Essa é uma forma modal de construção discursiva que mostra o baixo grau de comprometimento de Eduardo em sua narrativa.

Desse modo, o que Eduardo diz nas linhas 1 e 2 é que a política de cotas é um "fracasso", repetindo a frase "como política é um fracasso", entre longas pausas. A repetição traz o tom de reforço no que ele está querendo emitir. Essas construções fazem parte da idealização do estigma de desastre iminente sobre a política de cotas. A política é um erro e é um fracasso e como, a partir disso, ela pode dar certo?

Outra forma de descreditar a política de cotas que encontrei em meus dados foi a que aparece na narrativa de Vicente, no excerto 25. O professor compara modalidades diferentes de cotas. Na realidade, ele nomeia como cota o financiamento FIES, realizando a comparação com os alunos "cotistas" do CEFET/RJ e de outra instituição na qual ele trabalhou antes do CEFET/RJ, que também utiliza a política de cotas. Então, a pergunta que faço nesse ponto da 
entrevista, após todas as experiências que ele contou, é se ele é contra ou a favor das cotas.

Excerto 25: "o pessoal sem interesse"

\begin{tabular}{|c|c|c|}
\hline Allane & $\begin{array}{l}1 \\
2\end{array}$ & $\begin{array}{l}\text { e aí você particularmente no final disso tudo na experiência que você } \\
\text { teve antes e depois você é contra ou a favor (.) das cotas? }\end{array}$ \\
\hline Vicente & 3 & eu sou contra $(1.0)$ \\
\hline Allane & 4 & tem alquma explicação mais \\
\hline Vicente & $\begin{array}{l}5 \\
6 \\
7 \\
8\end{array}$ & $\begin{array}{l}\text { é pelo:: pelo:: (.) que eu te falei eu acho que num (1.0) até na=na=na } \\
\text { eu=pr=pra você ter uma ideia eu comparo né }(.) \text { o cotista da escola } \\
\text { pública o cotista da escola particular o cotista de escola particular é o } \\
\text { cara que pega o FIES né }\end{array}$ \\
\hline Allane & 9 & é sim \\
\hline Vicente & 10 & pode dizer assim \\
\hline Allane & 11 & ou é tem bolsa né \\
\hline Vicente & $\begin{array}{l}12 \\
13 \\
14 \\
15 \\
16 \\
17 \\
18 \\
19 \\
20 \\
21 \\
22 \\
23\end{array}$ & $\begin{array}{l}\text { é ou então tem bo:Isa (.) é completamente diferente na } \\
\text { ((universidade)) o cara (.) tipo assim ele passou tinha uma aluna minha } \\
\text { que passou com média } 8,5 \text { (.) "professor posso fazer a } 3 \text { pra melhorar } \\
\text { minha média" pra você ter uma ideia né (.) aqui não o cara:. (.) tava } \\
\text { até conversando com outro colega não sei se você conhece o } \\
\text { ((professor)) que é de ((disciplina)) ele falou comigo "vicente eu peguei } \\
\text { uma turma do ((professor) })^{*} \text { que ele voltou de licença agora né (1.0) ai } \\
\text { "eu peguei uma turma do ((professor)) que tava no terceiro semestre } \\
\text { do integrado de ((curso))" eu acho que é de tarde né ele (.) dando aula } \\
\text { o pessoal sem interesse ele falou "gente mas porque isso?" "professor } \\
\text { já passei" (1.0) porque chega no terceiro bimestre você tem } 8,8,8 \\
\text { você já passou }\end{array}$ \\
\hline Allane & 24 & aham \\
\hline Vicente & 25 & com 24 pontos né \\
\hline Allane & 26 & aham \\
\hline Vicente & $\begin{array}{l}27 \\
28 \\
29 \\
30 \\
31 \\
32 \\
33 \\
34 \\
35 \\
36\end{array}$ & $\begin{array}{l}\text { então tipo assim eles que (.) tipo assim que vão estudar pras outras } \\
\text { matérias (1.0) já na faculdade particular é completamente diferente } \\
\text { eles tão eles têm o investimento do dinheiro né então o que que } \\
\text { acontece os cotistas lá que são os bolsistas e o pessoal do FIES (.) } \\
\text { são super interessados são aqueles que ficam em ci: ma tiram dú::vida } \\
\text { procuram monitoria então é eu acho até que o=a o tipo de=de cota né } \\
\text { (.) tipo de (.)é de (.) metodoloqia da nossa da nossa dos nosso sistema } \\
\text { de cotas pra escola pública (.) que eu acho que a gente tinha que ter } \\
\text { uma (.) eu não sei como mas tinha que ter uma revisada nisso aí (1.0) } \\
\text { porque primeiro cinco né (.) cê falou que são cinco né (.) é muita co:isa }\end{array}$ \\
\hline
\end{tabular}

Na linha 3, Vicente é enfático ao dizer que é contra, e na linha 4, eu indago se ele tem uma explicação mais aprofundada sobre a opinião que ele emitiu. Em seu resumo (L5 a L8), o professor segue nas linhas 6 e 7 explicando que ele compara o "cotista" de escola pública com o "cotista" de escola particular. Eu sigo a interação direcionando para o que penso sobre o "cotista" de escola particular que, particularmente, não considero como tal, mas sim como bolsista. Porém, Vicente segue mantendo a analogia e comparação entre ambos, posicionando-os sob a mesma categoria. 
Quando Vicente começa a sua ação complicadora, na linha 13, ele conta a história de uma aluna que havia passado com média alta com a quantidade de avaliações necessárias (que para o segmento subsequente, ao qual ele fazia referência, em cumprimento ao regimento interno, são duas). Ele relata que é oferecida a oportunidade de realizar a terceira prova, que oficialmente é uma prova de recuperação para quem não passou nas duas primeiras, mas que a aluna opta por não realizar, deixando de lado a oportunidade de melhorar a sua média. Vale ressaltar que Vicente considera que, em sua opinião, a aluna deixou de melhorar a sua média porque estaria "largando" a escola por já ter passado.

E é assim que ele inicia a caracterização desse "cotista" de escola pública, como o descompromissado e que não utiliza tudo que ele e os docentes julgam como necessário, mesmo que todas as etapas oficiais tenham sido cumpridas pela aluna. Vicente segue, então, com a narrativa sobre o ensino integrado, que é o foco da minha pesquisa. Na linha 21, ele já descreve os alunos como "pessoal sem interesse", mas ele traz isso na voz de outro professor, se retirando da história como avaliador e entregando ao professor que ele cita a opinião que foi emitida sobre os alunos. Aqui ele realiza uma avaliação de sanção social (MARTIN; WHITE, 2005; NÓBREGA, 2009; WHITE, 2004), já que indaga ou questiona implicitamente a conduta dos alunos que supostamente não tem interesse.

Para dar corpo à história que ele está narrando, ele traz a voz dos alunos ("professor, já passei", L21 e L22), com uma narrativa que ele ouviu do outro professor. Esses alunos dizem que estão sem interesse porque já passaram de ano no terceiro bimestre. O que Vicente está dizendo, explicando autoetnograficamente o contexto, é que o professor que ele cita é um professor e uma disciplina mais "tranquilos". E, por esse motivo, os alunos já tiram 8 nos três primeiros bimestres, não havendo mais a necessidade de obter pontuações a mais para passar de ano. Por conta disso, ele relata que os alunos deixam de mostrar interesse ou se interessar pela disciplina. Vicente está avaliando que os alunos decidem que não é mais importante estudar quando a pontuação já foi atingida, deixando evidente que julga o desinteresse dos alunos, realizando, então, uma avaliação de estima social (MARTIN; WHITE, 2005; NÓBREGA, 2009; WHITE, 2004).

Isso é relacionado diretamente aos alunos "cotistas" de escola pública, pois, em momento posterior, ele continua relatando que os alunos "cotistas" de instituição particular não deixam de se interessar e nem "abandonam" as disciplinas, pois precisam manter médias numéricas altas para que mantenham o recebimento de bolsas de estudo. Veja, não estou nesse momento questionando 
a veracidade da experiência que o docente viveu nas instituições que cita e que trabalhou, mas é preciso deixar manifesto a construção que o docente realiza sobre os alunos "cotistas" e como isso se relaciona diretamente à desmoralização da política de cotas no CEFET/RJ, que é exatamente uma instituição pública que ele cita.

$\mathrm{Na}$ ação complicadora de sua narrativa, Vicente explica melhor essa comparação que idealiza (L27 a L34), trazendo a ideia de que somente os alunos na escola particular "têm o investimento do dinheiro" (L29). Essa ideia fica evidente por Vicente utilizar o item "completamente" (L28) para dizer que na instituição particular é completamente diferente. Quando o docente utiliza esse termo, ele está realizando uma avaliação de sanção social (MARTIN; WHITE, 2005; NÓBREGA, 2009; WHITE, 2004).

Nesse ponto, está sendo construída a ideia de que o aluno de instituição pública não tem subsídio direto (como a bolsa de estudos), o que pode auxiliar na solidificação do sistema de coerência de senso comum de que as vagas sejam um bem privado, e não público. Sendo esse sistema atualizado, passa a haver a construção do sentido de que esse bem, que não é público porque, por esse caminho que Vicente narra, não existe investimento "visível" para a vaga da instituição, esta vaga passa a não ser do "cotista".

O professor explicita que o "pessoal" do FIES é "super" interessado, utilizando mais um item que intensifica a avaliação do aluno bolsista. Esse é o aluno que "vale" o investimento que recebe, pois é o que "fica em cima" (L31), "tiram dúvida" (L31), "procuram monitoria" (L32). Por oposição, Vicente está construindo, pela gradação, a imagem inversa do aluno "cotista" da instituição pública. E nessa distinção, todos os itens que ele utiliza podem avaliar o aluno do CEFET/RJ como quem não fica em cima, como quem não tira dúvida e como quem não procura a monitoria. Assim, ele avalia por estima social (MARTIN; WHITE, 2005; NÓBREGA, 2009; WHITE, 2004) o aluno matriculado pelo sistema de cotas.

Das linhas 32 a 34, Vicente atribui a culpa da política não estar certa à metodologia que o CEFET/RJ utiliza para a distribuição das cotas, em atendimento à legislação. Em momento anterior, ele pergunta como é feita essa distribuição e eu explico, durante a entrevista, como ocorre a divisão e a subdivisão das cotas especificamente no CEFET/RJ. Então, ele termina a ação complicadora realizando uma crítica a essa forma e realiza uma coda avaliativa (LABOV, 1972). sugerindo que deva haver uma revisão no sistema vigente atual de distribuição de vagas de cotas. 
Vicente utiliza o item "muita coisa" para definir que a distribuição em cinco grupos de cotas é errada, em sua visão, sem definir do que se trata o que ele define como muita coisa. Entendo que ele esteja direcionando a crítica ao repartimento do número de vagas em muitas ramificações (para relembrar como é realizada essa divisão, sugiro consultar o capítulo 1, em que explico detalhadamente como ocorre).

O mesmo professor continua desqualificando a política de cotas, trazendo a figura do cenário caótico (WODAK et al., 2009) em sua narrativa não canônica que exponho no excerto 26 . Nesse momento da entrevista, eu direciono a pergunta de modo mais direto sobre o sentimento que ele teve ao saber que entrariam alunos no CEFET/RJ pela política de cotas.

\section{Excerto 26: "foi justamente o que aconteceu"}

\begin{tabular}{ccll} 
Allane & $\mathbf{1}$ & tá então vamo (.) vou perguntar pra você sobre o integrado quando você \\
& $\mathbf{2}$ & soube que iam entrar alunos de cota metade das vagas pra cota (.) que \\
& $\mathbf{3}$ & que você pensou que ia acontecer \\
\hline \multirow{3}{*}{ Vicente } & $\mathbf{4}$ & eu já pensei que ia acontecer isso pensei que a gente já ia ter uma (.) \\
& $\mathbf{5}$ & decaída no:.: no:.: né na qualidade né não de ensino mas na qualidade \\
& $\mathbf{6}$ & de aprendizado dos alunos (.) né (.) e foi justamente o que aconteceu
\end{tabular}

O que Vicente faz é construir esse local negativo, em que deu errado atender à legislação da política. O professor anuncia qual era a sua expectativa deixando evidente que essa era negativa e relacionando-a à perda de qualidade na escola. $\mathrm{Na}$ linha 6 , a sua pequena ação complicadora conclui o que ele antecipou que seria, dizendo que foi "justamente" o que aconteceu. Vicente diz que o seu temor não era pela queda do ensino, mas a queda da qualidade de aprendizado. $O$ item "justamente" é um modal com alto grau de comprometimento (HALLIDAY, 1985) de Vicente.

Essa formação discursiva (FOUCAULT, 1996) que Vicente revela é comum nas discussões acerca do processo de ensino e aprendizagem nas escolas. O discurso dominante é a ideia de que, se dá errado, é porque os alunos não sabem aprender e não porque nós, professores ou escola, não soubemos fazer. Essa ideia é comum, inclusive, na avaliação sobre todos os alunos do CEFET/RJ, mesmo antes da política de cotas, quando, em conselhos de classe, toda a discussão é centralizada no aluno como culpado por não conseguir passar de ano ou aprender. Em nenhum momento nessas reuniões é admitido tocar na possibilidade de haver um problema na condução do docente sobre os alunos, sobre as turmas e/ou sobre o currículo. 
Mas, mesmo sendo um ideário antigo que mostra força assimétrica que o CEFET/RJ tem sobre os alunos, mantenho a análise voltada aos alunos "cotistas" e à política de cotas. Quando Vicente faz essa relação entre seu medo e o que para ele de fato ocorreu, ele está indiciando mais um estigma sobre o aluno "cotista", ao dizer que o aluno é responsável por alguma queda de qualidade, dentre as "muitas qualidades" que o CEFET/RJ sustenta, principalmente para a comunidade externa.

Do mesmo modo que ele posiciona quem é o responsável pela perda de qualidade, ele também ratifica em qual posição ele se coloca e coloca os docentes representantes da escola, qual seja, a de que por parte dos professores não houve qualquer culpa. Vicente indica diretamente a distinção de quem é o responsável pela culpa, quando faz o contraponto "não de ensino mas na qualidade de aprendizado" (L5 e L6).

Ainda retomando o item "justamente" (L6), ele denota a certeza de sua razão, como se houvesse uma ideia de completude que se projeta ao final, para ratificar a certeza de que o sentimento negativo que teve estava correto. Dessa forma, entendo que o termo seja um intensificador lexical que Vicente usa para que sua narrativa ganhe força e validade frente ao assunto que estamos discutindo naquele momento interacional da entrevista.

Mas o mais importante desse excerto é a retórica de construção do grave cenário que as cotas trouxeram à escola. Vicente engendra um quadro desfavorável para trazer à tona em seu discurso o malefício da política de cotas. Ele não só pensou no que ia acontecer sobre a decaída da qualidade, mas teve certeza quando os alunos entraram e, em um tom enfático, ele desenha o anúncio como que se dissesse "eu avisei". E assim é construído o contexto de tragédia que representa não só o que Vicente pensava, mas toda uma comunidade escolar que ele está representando, que são os docentes do CEFET/RJ.

De modo bastante parecido, a narrativa de Paloma, no excerto 27, traz essa expectativa pelo desastre pós-política de cotas.

\section{Excerto 27: "eu esperava que ia ser um arraso, que ia ser uma avalanche"}

1 então assim (2.0) foi bom (.) foi melhor do que eu esperava sim (.) eu

2 esperava que ia ser um (1.0) arra:.:so(.) que ia ser uma avalanche (.) eu

Paloma 3 não vi nenhum resultado concreto (1.0) assim eu não sei se vocês estão

4 fazendo esse levantame::nto (1.0) dos que entraram por cota dos que

5 saíram por cota sem botar no: :me 
A professora inicia a sua pequena narrativa com o resumo na linha 1 ("então assim foi bom foi melhor do que eu esperava") e segue para a ação complicadora ao final dessa linha e nas linhas 2 e 3 ("eu esperava que ia ser um arraso que ia ser uma avalanche eu não vi nenhum resultado concreto"). A sua ação complicadora demonstra poucas conclusões, mas mostra que o que Paloma vê não é ainda "resultado concreto". Entendo que ela esteja dizendo que não foi a "avalanche" que ela esperava, mas também não consegue dizer que foi bom, quando diz que não viu resultado concreto.

É preciso atentar para o termo "avalanche", que é metáfora de algo incontrolável que a força da natureza exerce. A queda intensa, violenta e repentina da neve que ocorre em uma avalanche nos indica a força do que Paloma define em sua opinião sobre cotas. Os alunos "cotistas", por essa definição, sofreriam uma queda rápida e intensiva ao entrarem no CEFET/RJ. Esse item denota uma avaliação de Julgamento de estima social (MARTIN; WHITE, 2005; NÓBREGA, 2009; WHITE, 2004), tendo em vista que trata de questões morais que Paloma traz em sua opinião e nas metáforas de sua narrativa.

Em seu sentido figurado, uma avalanche indica aquilo que invade impetuosamente e, por meio desse significado, é possível entender quais sentidos Paloma dá ao aluno que acessa o CEFET/RJ pela política de cotas. Esse mesmo significado foi dado ao aluno "cotista", pelo termo "enxurrada", na narrativa do excerto 2, analisada na primeira seção deste capítulo. É interessante notar que analogias com forças incontroláveis aparecem em outras narrativas, não apresentadas aqui, da minha pesquisa.

Do mesmo modo, sentimentos descontroláveis descritos nas narrativas também fazem parte dessas descrições do incontrolável quando se fala de alunos "cotistas", trazendo uma dimensão do Afeto (MARTIN; WHITE, 2005; NÓBREGA, 2009; WHITE, 2004), avaliando as emoções dos docentes. Portanto, não são apenas as situações que perdem o norte quando se fala em política de cotas, mas também os sentimentos retratados. Na narrativa de Jeremias, no excerto 28 , fica manifesto o cenário de local terrível, através de situações que ele e seu colegiado estavam esperando com a entrada da política de cotas. 
Excerto 28: "a gente esperar qualquer coisa"

\begin{tabular}{|c|c|c|}
\hline Jeremias & $\begin{array}{l}1 \\
2 \\
3 \\
4 \\
5 \\
6 \\
7 \\
7\end{array}$ & $\begin{array}{l}\text { assim a:: pra mim não fez grande:: impacto em termo assim de } \\
\text { aceitar ou não aceitar pra mim tava normal dentro do que eu } \\
\text { pensava que deveria ser mesmo (1.0) é:: mas houve uma } \\
\text { preocupação minha como coordenador na época de alertar os } \\
\text { professo:res que ia vir um público com menos (.) é:.: ensino de ba::se } \\
\text { (1.0) é:: com talvez mais dificuldade de relacioname:.:nto a gente } \\
\text { esperar qualquer coisa porque a gente não sabia exatamente com } \\
\text { é que }\end{array}$ \\
\hline Allane & 9 & claro \\
\hline Jeremias & $\begin{array}{l}10 \\
11 \\
12 \\
13 \\
14 \\
15 \\
16 \\
17 \\
18 \\
19 \\
20\end{array}$ & $\begin{array}{l}\text { como é que ia ser isso foi uma preocupação que a gente teve na } \\
\text { época de conversar pessoalmente com cada professo::r fazer } \\
\text { dentro de reuniôes tocava no assu::nto (.) de como é que devia ser } \\
\text { o comportamento na sala de a:ula os professores terem cuidado } \\
\text { com o que fa::lam né pra não gerar nenhum problema } \\
\text { principalmente atrito né (.) e a gente acabou observando na primeira } \\
\text { tu:ma (.) teve=teve problema com o (.) não necessariamente com } \\
\text { a questão racial mas com o problema da cota em si (1.0) né (.) teve } \\
\text { muita gente que:: não entrou pelo processo de cota achou que:.: (.) } \\
\text { a cota (.) não era legal porque nã:o (.) dava mérito à pessoa que } \\
\text { tava entrando por cota né }\end{array}$ \\
\hline
\end{tabular}

A narrativa de Jeremias tem uma avaliação encaixada logo em seu início, no resumo da linha 1 à linha 3 ("assim ah pra mim não fez grande impacto em termo assim de aceitar ou não aceitar pra mim tava normal dentro do que eu pensava que deveria ser mesmo"). Ele traz itens os modalizadores "assim" e "pra mim" logo na linha 1, indicando o baixo grau de comprometimento do docente (HALLIDAY, 1985). O professor já avalia não só que para ele a entrada de alunos novos por cotas não teve impacto, como também que não havia modificado o que ele havia esperado que fosse ocorrer. Isso não indica que não tenha havido expectativas ruins sobre os alunos "cotistas", mas que houve alguma expectativa e que essa estava correta.

Não há como saber quais eram exatamente essas expectativas, já que ele não as explicita nesse ponto da narrativa, mas é possível detectar que ele esperava que viessem alunos com pouca base de conteúdos e de dificuldade de relacionamento, pelo discurso contido em sua ação complicadora, da linha 3 à linha 17. Isso indicia que o aluno "cotista" é um aluno sem base e que tem dificuldades de se relacionar com outras pessoas. Entendo que quando Jeremias diz que o colegiado teve a preocupação com os assuntos que seriam abordados e como deveriam se comportar em sala de aula diante dos alunos "cotistas", ele está criando uma imagem de cuidado com o lidar com o aluno. Isso instancia o 
aluno como aquele que é incapaz de entender as relações interpessoais a ponto de ouvir críticas opostas às cotas, por exemplo, e criar confusão.

Mesmo que o assunto de cotas já existisse em forma de debates em sala de aula antes do atendimento à legislação, não me parece ter sido preocupação dos docentes abordar o tema ou ter que fazer reuniões personalizadas para moldar um comportamento controlado. Mas Jeremias traz essa preocupação e descreve em sua ação complicadora como ele agiu, sendo coordenador, com os docentes de forma a orientá-los sobre tudo isso. Ou seja, apenas tornou-se necessário tanto cuidado nas ações e palavras porque, a partir de então, os alunos que entrariam no CEFET/RJ não saberiam lidar com a discussão de determinados temas e poderiam gerar algum problema e "atrito".

O próprio termo "atrito" que Jeremias usa já indica a figura do choque, que significa o desacordo ou a divergência entre partes. Digo partes no sentido de particionadas mesmo, para desenhar o sentido que encontro no que Jeremias fala sobre o controle do comportamento do docente frente ao aluno "cotista". Ele espera que o aluno seja uma das partes e salva resguarda os docentes, que são a outra parte e a parte "controlável", para a evitação do conflito que ele espera que haja caso o aluno "cotista" entre em contato com divergências ideológicas sobre cotas.

Jeremias termina sua ação complicadora citando, superficialmente, o problema que ocorreu com uma das turmas do núcleo técnico de seu colegiado enfatizando que não foi pela questão racial, mas pela questão das cotas em geral. Entendo que o docente tenha trazido essa história ao final para dar corpo ao que havia dito sobre evitação de problemas. Por meio da exemplificação do que ele estava contando, sua história e os sentimentos que cercaram a sua narrativa estariam mais validadas.

A coda avaliativa de Jeremias ( $L 17$ à L20) traz uma opinião reportada de "muita gente" que não acha a cota "legal" por retirar o mérito da vaga. Ele reporta essa fala como justificativa da própria história que relata e para explicar o porquê de ter tido todo o cuidado com o comportamento dos docentes que coordenava. Nesse ponto da narrativa, ele realiza uma avaliação que justifica sua ação direcionada aos docentes pelo medo iminente da reação dos alunos "cotistas", caso algum docente trouxesse temas divergentes ou atitudes que abririam atritos em sala de aula.

Nesse cenário "terrível", há também as histórias pessoais dos alunos "cotistas", que são narradas pelos docentes para dar corpo a construções de estigmas relacionados à estrutura familiar dos alunos, conforme já discuti aqui. No 
excerto 29, a narrativa de Ana mostra essa construção, de modo que desenha a angústia da professora em ter que lidar com novos alunos com histórias como a que conta.

Excerto 29: “jamais pensei em lidar”

\begin{tabular}{|c|c|c|}
\hline \multirow{9}{*}{ Ana } & 1 & ive uma aluna (1.5) é:.: um caso horrível que:: que:: eu jamais? pens \\
\hline & 2 & em lidar? (2.0) é:: aluna falando pra mim que:: é:: (1.0) que tava \\
\hline & 3 & sendo abusada do pai (3.0) hh e já morava? em abrigo >essa menina \\
\hline & 4 & morava em ab nunca tive aluno $<$ que morasse em abrigo? sempre \\
\hline & 5 & tive aluno (.) que tivesse bom menos que fosse tudo bem >pais \\
\hline & 6 & separados tudo bem mas tivesse pai mãe que fosse uma \\
\hline & 7 & referência?< aí falei assim >"por que que ce não mora com a tua \\
\hline & 8 & mãe? aí falou assim=porque a minha mãe foi esquartejada< pelo \\
\hline & 9 & amante $^{n}$ ? \\
\hline Allane & 10 & meu deus \\
\hline Ana & $\begin{array}{l}11 \\
12\end{array}$ & se tipo de aluno? q \\
\hline & 12 & \\
\hline
\end{tabular}

Nas linhas 1 e 2, já no resumo, apresenta itens avaliativos do que está para contar. Mais uma vez, traz o ineditismo da situação quando diz que jamais pensou em lidar com o "caso horrível" da aluna, como define, dessa vez, trazendo um elemento intensificador lexical (adjetivo "horrível"). Essa introdução da história em seu resumo também nos leva a pensar que uma situação "horrível" não aconteceria com o perfil de alunos anterior ao perfil da entrada dos "cotistas".

Recorro, em paralelo, ao sistema de avaliatividade para entender que a docente realiza a primeira expressão avaliativa de Afeto autoral (MARTIN; WHITE, 2005) ao usar os itens "horrível" e "jamais", caracterizando uma avaliação externa. Os recursos paralinguísticos utilizados estão, também, na prosódia, com os três alongamentos de vogais, as duas grandes pausas e as quatro modificações de entonações, em apenas sete segundos de fala, caracterizando, ao mesmo tempo, as avaliações encaixadas (NÓBREGA, 2009, p. 79-80).

A história contada segue o padrão de alinhamento ao senso comum de que os alunos "cotistas" não se encontram em núcleo familiar organizado segundo normativas sociais estabelecidas pela e para a dita classe média. São alunos pobres, como histórias de vida construídas, vivências catastróficas embaladas por tragédias diversas. E é dessa forma que a docente constrói, na orientação de sua narrativa, a história sobre uma aluna "cotista" do CEFET/RJ, acionando diversos itens de avaliação.

Da linha 4 à linha 7 ("nunca tive aluno que morasse em abrigo sempre tive aluno que tivesse bom menos que fosse tudo bem pais separados tudo bem mas 
tivesse pai mãe que fosse uma referência"), a professora utiliza os advérbios "nunca" e "sempre" e delimita em que momento temporal ela passou a ter alunos, segundo ela, sem estrutura familiar, trazendo novamente o que parece ser uma linha imaginária que separa momento/aluno bom e momento/aluno ruim. Essa análise fica melhor explicada na Figura 1:

Figura 1: Antes e depois das cotas.

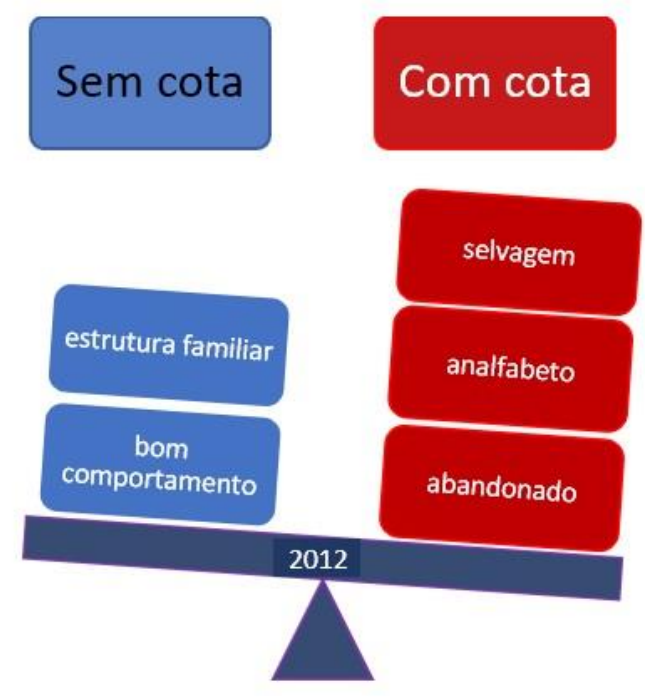

Fonte: Elaborado pela autora (2020).

Quando Ana avalia na dimensão do Julgamento (MARTIN; WHITE, 2005), pelos itens oposicionais "nunca" e "sempre", essa carga dramática se evidencia ao mostrar o peso negativo que o aluno "cotista" traz a sua vida e à vida dos docentes. A estima social dessa dimensão aparece, também, quando ela indica que o aluno não tem "referência" familiar (L7), diferente dos demais alunos para os quais ela estava acostumada a ministrar aula. Quando a professora define o que para ela significa "tudo bem" ("mas tivesse pai mãe que fosse uma referência") expõe, ali, que os alunos "cotistas", representados nessa terceira narrativa pela aluna com a história trágica, não têm seus pais como referência, por contraste.

Da linha 7 à linha 9, Ana desenvolve a ação complicadora de forma breve. A docente coloca peso dramático nas palavras utilizadas para descrever o crime. Considerando que o esquartejamento é uma morte e poderia ser representada pela própria definição original (morte), sem o detalhamento de que morte se estava falando, a docente deixa evidente essa carga dramática da história. Do mesmo modo, encontramos na palavra "amante" um item lexical avaliativo, tendo em vista a utilização dele com sua definição socialmente estabelecida como erro sob o 
modelo tradicional de relacionamento em detrimento de outras palavras eufemizantes, como "companheiro" ou "um homem" de forma genérica.

Nesse momento, há um posicionamento de Julgamento de sanção social (MARTIN; WHITE, 2005), também sobre o comportamento da mãe da aluna. Ou seja, apesar de ser uma ação complicadora pequena, vem carregada de diversas avaliações e julgamentos morais sobre a situação familiar da aluna "cotista" protagonista da história narrada. $\mathrm{O}$ ritmo acelerado com que reporta a fala da aluna, nas linhas 7, 8 e 9 ("por que que cê não mora com a tua mãe aí falou assim porque a minha mãe foi esquartejada pelo amante"), também é um recurso para a construção desse julgamento.

Ana desenvolve a avaliação (LABOV, 1972) de sua narrativa, nas linhas 11 e 12, e o distanciamento da docente com os alunos "cotistas" se explicita na forma "esse tipo de aluno", utilizada por ela para realizar a consequência da ação complicadora. O viés simbólico desse afastamento se completa com a forma "que a gente tem que lidar", definindo a obrigatoriedade estabelecida de trabalho com os alunos "cotistas", avaliando na dimensão do Afeto (MARTIN; WHITE, 2005) e marcando o sentimento de compulsoriedade ("tem que lidar").

Em mais uma narrativa de Paloma, no excerto 30, ela descreve a tragédia que é o aluno que é jubilado e não consegue se realocar mais em nenhuma escola devido ao currículo diferenciado que o CEFET/RJ tem.

\section{Excerto 30: "eles tiram a vaga de alguém"}

1 é uma pena porque eles tiram a vaga de algué::m (2.0) ficam quatro anos

2 batendo cabeça aqui (1.0) aí (.) o curso daqui quando você termina você

Paloma 3 não aproveita em lugar nenhum allane (.) não aproveita (.) na da eu sei

4 porque eu acompanhei né (.) você chega lá fo:.ra (1.0) eles não (.) um

5 como=um ou outro colégio consegue fazer uma adaptação desse nosso

6 ensino mé:.:dio mas não consegue (.) eles acabam no supleti:.vo

Paloma evidencia o discurso de posse da vaga federal que não é esperado que seja do aluno "cotista". Em seu resumo, na linha 1, já realiza uma avaliação com o item "pena" para realizar a metáfora de que o aluno "tira" a vaga de alguém. A começar pela ideia de que só é possível tirar algo de alguém quando a última possui determinada coisa, há uma metáfora de um dono para a vaga. Considerando que, na história de Paloma, o aluno "cotista" é o que tira a vaga de alguém, o dono da vaga não é ele. Do ponto de vista da avaliação, Paloma realiza um Julgamento de sanção social (MARTIN; WHITE, 2005; NÓBREGA, 2009; WHITE, 2004), considerando que, sob sua perspectiva, a docente realiza uma 
avaliação ética sobre sua concepção de posse de vaga. Há diversos sistemas de coerência nessa formação discursiva que são de grande importância para a discussão do modo como os estigmas são criados.

Aprofundando a análise dessa metáfora, o aluno "cotista" que rouba a vaga de alguém já foi analisado neste capítulo no excerto 1 , de Pedro, e excerto 4 , da própria Paloma. A partir da história agora do excerto 30, gostaria de atentar para a relação direta que o sistema de coerência contido nessa metáfora constrói, consequentemente, um aluno que não saberá aproveitar a oportunidade dada a ele por este outro alguém dono da vaga e pela instituição, pela política de cotas.

Isso aparece na forma como Paloma inicia a sua ação complicadora, na linha 2, dizendo que eles ficam quatro anos no CEFET/RJ "batendo cabeça". Apesar do trecho que recortei parecer que Paloma fala sobre a formação do aluno de cotas, ela está falando do jubilamento. Quando termina o prazo de dois anos consecutivos, que são o limite para a saída da escola, eles não conseguem, segundo a professora, aproveitar nada do que tiveram de conteúdo curricular em outra escola. Há no item "batendo cabeça" um Julgamento de estima social (MARTIN; WHITE, 2005; NÓBREGA, 2009; WHITE, 2004), que avalia a (in)competência do aluno em permanecer na escola com a chance que the é "dada".

Ela reivindica a validação do que está dizendo quando diz que sabe do que está falando porque ela mesma acompanhou. Constrói sua avaliação (LABOV, 1972) em forma de coda avaliativa, afirmando que nenhum outro colégio consegue adaptar o currículo "desse nosso" ensino médio. Há um distanciamento aparente quando ela usa o termo "desse", distanciamento esse de ideia sobre o currículo integrado, que foi amplamente contestado pelo núcleo técnico do CEFET/RJ, ao qual ela pertence.

Mas o importante nessa narrativa é a construção do imaginário do quanto as cotas são prejudiciais aos alunos que não conseguem aproveitar a oportunidade que lhes é dada pela vaga que é "transferida" de seu dono para o aluno "cotista". É um cenário caótico (WODAK et al., 2009) em que a política que deveria ser benéfica ao aluno surge na narrativa de Paloma como responsável por trazer ao aluno problemas irreversíveis, já que, em seu imaginário, ele terá perdido quatro anos de sua vida com algo que ele nunca irá aproveitar. Ou seja, é uma política que traz fracasso aos alunos, além de "retirar" a vaga que é de direito de outro alguém. 


\subsection{1. Conclusões da seção}

Ao final dessa seção, é possível entender como se constrói discursivamente a estratégia de conservação do velho modelo. Ela é construída pelo topos do cenário desfavorável e caótico que a cota traz nos ambientes não apenas de trabalho, mas simbolicamente de vida pessoal, tanto dos docentes, quanto para os alunos "cotistas" e "não cotistas".

Para o ambiente de trabalho, com a entrada da política de cotas chegam, também, as dificuldades relatadas pelos professores em histórias com sentimentos densos. As dificuldades de trabalhar com os novos alunos, as dificuldades de estarem entrando em contato com supostas histórias de tragédias de vida, as dificuldades em perceber a suposta desestruturação familiar e psicológica dos alunos, as dificuldades em ter que repensar suas metodologias para atender aos alunos com tantos buracos em sua formação.

Para a vida pessoal dos alunos, em referência aos "cotistas", as narrativas que os docentes contam giram em torno de insucessos diversos. A começar pelas histórias sobre família que surgem, denunciando sempre anedotas extremas de situações parecidas com as que vimos em jornais televisivos sensacionalistas.

Em contrapartida, as descrições exageradas sobre a incapacidade dos alunos "cotistas" em permanecer na escola são construídas de modo a encorpar as narrativas de cenário caótico dos docentes entrevistados. As generalizações das situações, como a relatada pelo professor Marcelo, em que coloca todos os alunos "cotistas" como quem entregam trabalhos ilegíveis, ou as narrativas de Patrícia e de Vicente, que apresentam o esperado fracasso em bloco, adicionadas às opiniões de Eduardo, que verbalizam que a política de cotas é um fracasso, são discursos que modelam as bases do sistema de coerência sobre cotas e formam alicerces para os índices diretos sobre os alunos que entram nas instituições pela política.

Já ao aluno "não cotista" restam os danos causados tanto pela perda de qualidade da instituição quanto pela perda quase que material de vagas. É construída nas narrativas dos docentes entrevistados a ideia de que há determinada convalescência dos alunos de ampla concorrência em terem cedido suas vagas para o atendimento da política de cotas. Consequentemente, eles cederam, então, "suas" vagas aos alunos de cotas, trazendo a obrigatoriedade de esforço máximo ao aluno "cotista", já que ele recebeu esse "presente". 
Além de instanciar a ideologia do lugar onde cada aluno deveria estar pelo sistema de coerência da meritocracia, essa ideia instancia a nuvem de eterna gratidão que o aluno "cotista" deve ter para seus benevolentes cededores de seu bem, que é a vaga em uma instituição federal. Para melhor ilustrar os resultados desta seção, apresento o Esquema 6:

Esquema 6: Relação entre os estigmas, narrativas e modos de realização discursiva.

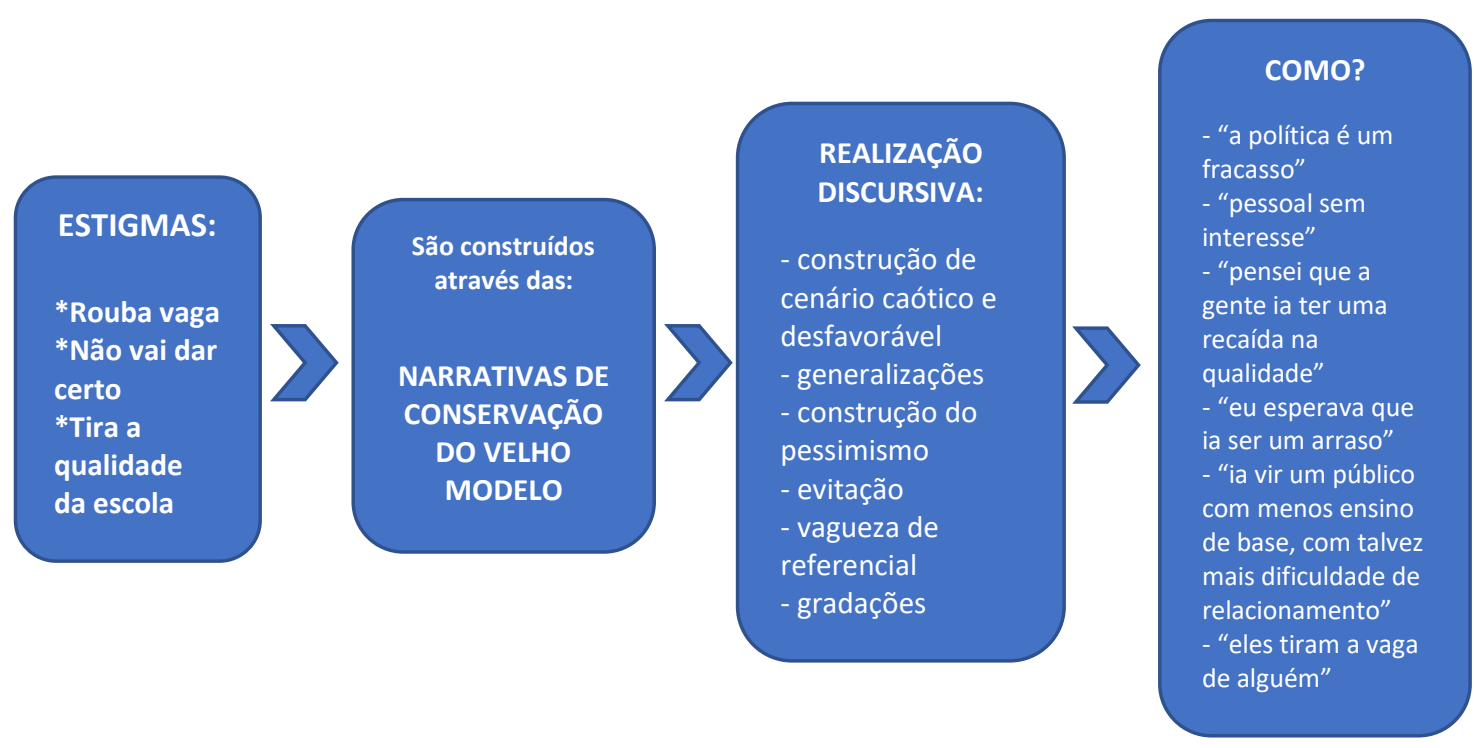

Fonte: Elaborado pela autora (2020).

$\mathrm{Na}$ próxima seção (5.5.) apresento as análises das narrativas que descreditam os alunos "cotistas" e a política de cotas, criando um caminho que pode levar à desvalorização da própria política.

\section{5 .}

Narrativas de descrédito dos alunos e da política de cotas

Nesta seção, trago, sob a ideia de Wodak et al. (2009), a estratégica de descrédito dos alunos da política de cotas. Entendendo que este é um dos componentes do discurso sobre cotas, a estratégia de descreditar a política e os "cotistas" reforça os estigmas sobre os alunos, conforme veremos agora. Como principais formas de construção discursiva, encontro as metáforas depreciativas sobre os alunos "cotistas" e a estratégia de pessimismo (WODAK et al., 2009), que também aparece em outras construções discursivas já discutidas neste capítulo. 
Mais uma vez estão presentes os topos de comparação que representam a força de determinada maioria sobre a minoria dos alunos de cotas junto a denotações depreciativas sobre os alunos. Essas atribuições depreciativas acontecem por meio de unidades lexicais com componentes semânticos que constroem singularidade em conexão com atributos negativos (WODAK et al., 2009). Para iniciar a análise dessas narrativas, apresento o excerto 31, de Pedro.

\section{Excerto 31: "ele tá lutando contra a maré"}

Allane 1 quer falar mais alguma coisa Pedro

2 (4.0) olha (1.0) é:: (2.5) relação a essa situação assim é: de cotas (1.0)

3 né (.) eu não tenho dados específicos assim pra:: pra:: pra te dizer se

4 desde a primeira turma do integrado se a gente teve uma:: uma maior

5 evasão menor inva=evasão né sobre esse tipo de=de aluno que entrou

Pedro 6 nessa faixa (1.0) sabe mas (.) me parece né assim (.) que.: e isso acho

7 que eu já vi alguns estudos no condmet né (.) quem acaba abandonando

8 mesmo é @o aluno que entra na ampla concorrência com a ideia de::

9 ter um ensino médio não pago né pago pelo governo em que ele taria

10 agregando uma formação técnica que ele poderia usar ou não no futuro

\begin{tabular}{|c|c|c|}
\hline Pedro & 12 & é exatamente \\
\hline Allane & 13 & e ao mesmo tempo com algumas outras qualidades \\
\hline Pedro & $\begin{array}{l}14 \\
15 \\
16 \\
17 \\
18 \\
19 \\
20 \\
21 \\
22 \\
23 \\
24 \\
25 \\
26 \\
27 \\
27 \\
28 \\
29 \\
30\end{array}$ & $\begin{array}{l}\text { então é esse aluno eu acho que é que entra na faixa de cotas é ele tá } \\
\text { lutando o tempo todo ali ele tá lutando contra a maré se ele já vem com } \\
\text { uma (.) uma dificuldade maior na formação né ele realmente é um:: um } \\
\text { guerreiro (.) mas eu eu tenho medo realmente de algum tipo de ação até } \\
\text { quando você me perguntou se a gente fazia algum tipo de ação (.) pra } \\
\text { tentar hh (.) é::é levantar (.) um pouco o conhecimento fazer com que } \\
\text { ele conclua o curso (.) eu tenho medo dele mesmo (1.0) né dele mesmo } \\
\text { se sentir é:: é segregado com isso (.) "tão me dando um tratamento como } \\
\text { se eu fosse um coitado" (1.0) sabe eu tenho medo disso quando eu } \\
\text { escuto as pessoas falando né que a gente talvez tivesse que ter um } \\
\text { olhar:: eu acho que esse olhar ele tem que ser muito singelo muito } \\
\text { superficial cê pode acompanhar:: tentar conversar especificam=mas do } \\
\text { momento em que se você cria alguma coisa de uma monitoria pros } \\
\text { alunos de cota:: alguma coisa assim aí você separa (1.0) aí você } \\
\text { nitidamente coloca uma barreira e ele vai ele se ele não tem uma auto } \\
\text { estima boa ele mesmo ele vai sentir "poxa (.) por que que eu tô sendo } \\
\text { tratado dessa forma?" }\end{array}$ \\
\hline Allane & 31 & ele vai perceber isso \\
\hline Pedro & 32 & ele vai perceber isso \\
\hline Allane & 33 & vai introjetar né \\
\hline Pedro & $\begin{array}{l}34 \\
35\end{array}$ & $\begin{array}{l}\text { sabe então eu sou contra esse tipo de coisas eu acho que:: as } \\
\text { oportunidades têm que ser dadas pra todos (.) assim }\end{array}$ \\
\hline Allane & 36 & pra todo mundo \\
\hline Pedro & 37 & como é dado (.) aberto pra todos \\
\hline
\end{tabular}


Pensando ser o final da entrevista, por terem se esgotado as questões do roteiro, pergunto ao professor se ele deseja falar mais alguma coisa. Pedro, então, segue por mais nove minutos falando sobre as cotas. Destes minutos finais, selecionei esse trecho por exemplificar, mais uma vez, a estratégia de pessimismo (WODAK et al., 2009, p. 42), indicando uma das formas como ocorre o desmantelamento da política de cotas a partir de topos de insucesso na caminhada dos alunos na escola.

Pedro inicia a narrativa mobilizando itens de modalização. Das linhas 2 a 6 ("olha é relação a essa situação assim é: de cotas né eu não tenho dados específicos assim pra pra pra te dizer se desde a primeira turma do integrado se a gente teve uma uma maior evasão menor inva evasão né sobre esse tipo de de aluno que entrou nessa faixa sabe mas me parece né assim que e isso acho"), ele resume e orienta a sua narrativa com bastantes pausas e hesitações que se intercalam com os modais "assim" (L2, L3, L6), "eu não tenho dados específicos" (L3), "nessa faixa" e "me parece mais assim" (L6) e "acho" (L14).

Nas linhas 5 e 6, Pedro se afasta dos alunos ("sobre esse tipo de aluno que entrou nessa faixa"), o que mostra a heteronomização (WODAK et al., 2009, p. 36), marcando o distanciamento e sustentando a noção de restrição (WODAK et al., 2009). O mesmo ocorre no início da extensa avaliação da narrativa do docente, das linhas 14 a 30, quando ele utiliza mais um item de afastamento e de avaliação negativa do aluno ("esse aluno", L14). Esse item carrega o julgamento negativo de estima social ou, no contexto específico que apresento, de uma sanção social (MARTIN; WHITE, 2005; NÓBREGA, 2009; WHITE, 2004). Como já apareceu em outras narrativas analisadas, é quase um crime ter "esse aluno" na escola. Acredito que seja daí que surja o grande esforço pelo distanciamento do aluno.

Nessa narrativa de Pedro, ele finalmente posiciona de forma direta o seu discurso, identificando o aluno do qual ele fala como sendo o "cotista". Há de se considerar que a demora no uso do termo "cotista" o identificado também cria um sentido. Pedro define todas as características sempre negativas do aluno, mas parece evitar usar a palavra "cotista" e parece, assim, evitar a identificação de qual aluno ele está falando.

Dessa forma, a construção do estigma de luta impossível fica ainda mais visível em diversos itens de avaliação de Pedro, não somente de Apreciação, (MARTIN; WHITE, 2005; NÓBREGA, 2009; WHITE, 2004), mas de Julgamento de estima social (MARTIN; WHITE, 2005; WHITE, 2004; NÓBREGA, 2009). A construção do estigma da incompetência do aluno já não fica mais velada a partir da estratégia de pessimismo (WODAK et al., 2009). 
Por essa estratégia discursiva, que habita a estratégia de descrédito (WODAK et al., 2009, p. 42) da política de cotas, é criado um cenário em que o aluno não consegue alcançar o sucesso escolar e passa por muitas "lutas" simbólicas que acaba perdendo. Nas linhas 15 e 17, Pedro evidencia essa luta ("lutando o tempo todo ali ele tá lutando contra a maré") inclusive avaliando o aluno como guerreiro. A figura do guerreiro traz à tona um cenário de guerra pelo qual o aluno perpassa quando entra na escola. Essa figura tem um atributo com significado altamente graduado que tanto pode ser visto como positivo, de estima social (MARTIN; WHITE, 2005; NÓBREGA, 2009; WHITE, 2004), se avaliado como um aluno que se esforça para tentar, como com o viés da estratégia de pessimismo, tendo em vista que é uma luta árdua.

Cabe aqui uma avaliação minha de pesquisadora/coordenadora que trabalha diretamente com os docentes e com todos os alunos. Posso afirmar, em minha experiência de 11 anos de CEFET/RJ, que essa "luta" não é só ônus de alunos que entram pela política de cotas. A luta para permanência em uma escola como o CEFET/RJ é tradicional e constante para todos os alunos, desde antes da política, mesmo quando recebíamos alunos oriundos das melhores escolas do Rio de Janeiro. Portanto, essa dificuldade foi transferida e entregue aos alunos de acesso pela política de cotas de modo que se tornou mais um dos muitos estigmas a eles atribuídos. Os itens de modalização de alto valor (HALLIDAY, 1985) das linhas 16 e 17 ("realmente") trazem à tona o posicionamento de Pedro no que se refere à luta árdua de manutenção dos alunos na escola, ratificando o Discurso desse estigma na instituição.

Nas linhas 19 e 20 ("tentar é é levantar um pouco o conhecimento fazer com que ele conclua o curso") encontramos mais itens de modalização utilizados para a construção, novamente, da figura do salvador, sustentando a apresentação positiva de si (WODAK et al., 2009, p. 39). Desta vez ele mesmo é o herói que traz as possibilidades para que o aluno conclua o curso. Do mesmo modo, Pedro avalia seu sentimento de "medo" na linha 20 à linha 22 ("eu tenho medo dele mesmo né dele mesmo se sentir é é segregado com isso tão me dando um tratamento como se eu fosse um coitado sabe eu tenho medo disso"). Porém, o medo que ele verbaliza sentir não é o medo genuíno que abrange uma preocupação literal da dimensão do Afeto (MARTIN; WHITE, 2005; NÓBREGA, 2009; WHITE, 2004). Entendo que esse medo representa o próprio Julgamento de sanção social (MARTIN; WHITE, 2005; NÓBREGA, 2009; WHITE, 2004) sobre o aluno já ser segregado e já ser um "coitado" que necessita de atendimento diferenciado. 
Próximo à finalização da avaliação narrativa do professor, na linha 28 ("aí você nitidamente coloca uma barreira"), novamente a estratégia de pessimismo (WODAK et al., 2009) constrói do estigma do aluno quando o auxílio especial da monitoria, oferecida a todos os alunos da escola, é metaforicamente transformada em uma "barreira", a qual o aluno "cotista" não consegue ultrapassar. Mais dois itens de modalização de alto valor (HALLIDAY, 1985) são utilizados ("barreira" e "nitidamente"), evidenciando tanto o nível de posicionamento do docente quanto a avaliação de estima social (MARTIN; WHITE, 2005; NÓBREGA, 2009; WHITE, 2004) sob o aluno.

A terceira narrativa de Pedro termina com uma coda avaliativa (Labov, 1972) na linha 37, mas optei por deixar uma pequena parte do restante da conversa como composição da contextualização desse excerto. Sem adentrar nova análise, apenas deixo apontado que as estratégias aqui analisadas continuam a acontecer, como nas linhas 44 e 45, em que o docente afirma que os alunos abandonariam e não suportariam o caminho escolar no CEFET/RJ. Vale a reflexão sobre essa construção retórica constante nas narrativas desse docente e dos demais docentes entrevistados.

Para exemplificar melhor a estratégia de pessimismo, trago mais uma narrativa da docente Ana, no excerto 32.

\section{Excerto 32: "há um muro invisível"}

1 mas foi a minha forma de observar (1.0) e eu comecei a me perguntar por 2 que que essas pessoas não frequentam a biblioteca (.) e não frequentam 3 monitoria (2.0) e aí eu comecei a perguntar (.) para os alunos (.) espremer 4 de alguma forma (1.0) e aí qual foi o meu susto que eu vi eu tive acho que 5 uns três ou quatro (.) que que eles não frequentavam por vergonha (.) por 6 não se sentir pertencente mesmo (.) né a (.) merecedores (1.0) ou (.) no 7 mesmo nível daquele lugar (.) por medo de serem discriminados também 8 (1.0) entã::o é uma coisa e (.) e assim aí eu ampliei um pouco (.) se vc tem 9 é (.) vc tem várias (.) vários lugares que se for ve be=aí va=vamos ampliar 10 vamos colocar rio de janeiro (1.0) bibliotecas públicas (2.0) centro cultural Ana 11 banco do brasil exposição de graça (1.0) você não vê o povão indo (1.0) e 12 é de graça (.) por que que eles não vão (.) porque eles não sent não sent 13 não se sentem que pertencem àque=àquele espaço (.) então há um muro 14 invisível (.) aí (1.0) certo (.) e:: e:: e esse muro é mu::ito=um :ito complicado 15 então mesmo que vc dê dinheiro pro cara (1.0) mesmo que você dê toda 16 a:: a:.s condições pro cara estudar e não sei o que ele não vai porque tem 17 uma barreira interna (.) essa barreira interna que também tá=tá fortemente 18 associada ao conceito de pobreza (.) é=é mu:.:ito difícil vc derrubar cara é 19 mu :ito difícil e pode ser (.) é que (.) imobilize o cara entendeu então acho 20 que isso é um lado que a gente tem que ser (.) tem que tratar com=com 21 mu: ito carinho (.) esses alunos 
Ana conta a história acerca do incômodo em perceber que os alunos "cotistas" não procuravam as monitorias que a escola oferece como política de permanência. Vale aqui trazer a informação, como atuante da coordenação pedagógica, de que os alunos precisam se prover individualmente ${ }^{43}$ para se manterem na escola no turno oposto, quando as aulas de monitoria acontecem. Dessa forma, caso o aluno tenha baixa renda, ou ele permanece no turno oposto de suas aulas regulares sem se alimentar ou eles optam por retornarem para casa.

Porém, em direção oposta ao que chamarei de adversidade financeira dos alunos, Ana já inicia sua ação complicadora, na linha 3, contando que resolveu perguntar aos alunos o motivo deles não frequentarem as monitorias. A resposta que a professora diz ter obtido foi a de que eles não frequentam por não se sentirem pertencentes àquele lugar. Mais uma vez há a "culpa" transferida ao aluno, agora sobre a busca por sua melhora acadêmica. Mesmo que essa culpa seja travestida de algo que Ana desenha com nuance de pena, quase verbalizando os alunos como "coitadinhos", há nesse ponto a transferência de culpa sobre sua evolução acadêmica na escola, como ocorreu em outros momentos das narrativas docentes já analisadas neste capítulo.

Na linha 3, ao início da ação complicadora, Ana utiliza o termo "espremer", que direciona ao entendimento de que não é algo explicitamente assumido pelos alunos a qualquer um. Mas ela projeta a imagem de que "espremendo" ela conseguiu extrair o grande motivo pelo qual os alunos "não frequentam" as monitorias. Vale ressaltar que, na orientação de sua narrativa, a professora dá ênfase, na linha 2, ao item "não frequentam", que repete duas vezes no mesmo ponto, trazendo determinada certeza e generalização de que eles de fato não frequentam.

Nas linhas 5, 6 e 7, Ana realiza uma gradação para ratificar o motivo pelo qual eles não frequentam, listando que é "por vergonha", depois "por não se sentir pertencente", depois "merecedores", depois "no mesmo nível daquele lugar" e, por fim, "por medo de serem discriminados". Parece haver um julgamento direto sobre o que ela acredita que ocorra com os alunos que justifica a não ida deles à escola no turno oposto ao regular para usufruir da política de permanência que é oferecida pelo CEFET/RJ.

A ação complicadora termina na linha 7 , e começa a longa coda avaliativa (L8 à L21) que muito diz sobre a concepção de Ana sobre a relação direta que ela realiza entre o aluno "cotista" e camadas populares bem adjacentes às estruturas

43 Esta informação se refere até o ano de 2019, quando a escrita da tese estava ainda em andamento. 
regulares de formação humana, como a escola e espaços cognatos, como bibliotecas. Ela diz que "ampliou" o que ela vê no CEFET/RJ para o Rio de Janeiro, e traz exemplos de bibliotecas públicas e centro cultural com exposições grátis. Na linha 11, ela identifica como "povão" a parcela da população que não se sente pertencente a esses espaços listados por ela. O Julgamento de sanção social (MARTIN; WHITE, 2005; NÓBREGA, 2009; WHITE, 2004) acontece de modo mais evidente quando Ana diz que eles não vão por opção, tendo em vista o suposto sentimento de não pertencimento a esses locais.

Nas linhas 13 e 14, de forma notória, Ana reforça o próprio argumento de que não adianta qualquer luta, quando diz que há um "muro invisível" e que é "muito complicado". Essas são formações discursivas que reforçam a ideia de pessimismo, já que um muro invisível sequer pode ser localizado para ser derrubado para que haja qualquer passagem do "povão" para o "outro lado" que ela descreve. Transpassar o muro invisível torna-se ainda mais sancionado por Ana quando ela utiliza de modo repetido o item "muito", na linha 14 ("muito muito complicado"). Ana entra na dimensão do Afeto (MARTIN; WHITE, 2005; NÓBREGA, 2009; WHITE, 2004) quando define com os intensificadores "muito" a sua avaliação emocional sobre a complicação.

Em seguida, a docente constrói mais reafirmações sobre a luta impossível por meio de mais uma lista de possibilidades que poderiam ser oferecidas ao "cara" (L15 e L16), mas que, ainda assim, não seria possível transpassar o muro. Nesse ponto, ela retorna a se referir ao aluno "cotista", direcionando o item "cara" para ele, pois ela regressa à ideia de estudo na linha 16 ("pro cara estudar"). Então, quando Ana lista que "mesmo que você dê dinheiro pro cara, mesmo que você dê todas as condições pro cara estudar" (L15 e L16), ele não aproveita a oportunidade por não se sentir pertencente àquele espaço. A professora realiza um Julgamento de sanção social (MARTIN; WHITE, 2005; NÓBREGA, 2009; WHITE, 2004) sobre o aluno desistente.

Nesse ponto de sua história, Ana parece entender o que eu disse logo ao início dessa análise, que é a questão financeira como forte impedimento para a permanência do aluno na escola no turno oposto ao seu turno oficial de estudo. Mas essa questão torna a ser secundária para que seja ratificado o argumento da professora sobre a escolha de não frequentar pelo sentimento de não pertencimento. Ou seja, o aluno não frequentar é opção dele devido a uma característica emocional intrínseca ao aluno "cotista", que vem de uma questão social, e mais uma vez há uma avaliação de sanção social (MARTIN; WHITE, 2005; NÓBREGA, 2009; WHITE, 2004). 
Ainda mais itens de avaliação são explicitados por Ana para que ela defina a desistência do aluno, como "barreira interna" que ela repete duas vezes na linha 17 para construir novamente a ideia de algo intransponível. A partir dessa construção, encontro mais um exemplo da estratégia de pessimismo (WODAK et al., 2009) que não apenas ameaça um futuro terrível, mas anuncia a impossibilidade de avanço positivo para o aluno.

A barreira interna, para Ana, está associada diretamente ao que ela concebe como "conceito de pobreza" (L18) e que é "muito difícil" de "derrubar" (L18) reforçado por "muito difícil" (L19). O muito difícil é de alta gradação e desenha a dificuldade de ter um suposto problema resolvido, de modo que qualquer luta árdua não consiga "derrubar" algo tão fincado e forte. O item "derrubar" também constrói a ideia da impossibilidade de vencer ou dominar o que Ana projeta estar determinado em sua história. Para completar a ideia, a docente usa o item "imobilize" (L19) que define, nesse momento, o estado do aluno diante de uma luta tão impossível de se lutar. Ao final, ele está imobilizado para agir em prol de alguma superação da situação descrita. Todos esses itens completam o argumento construído sobre a estratégia de pessimismo.

Nesse mesmo caminho, com a narrativa de Eduardo, no excerto 33, mostro como essa ideia é ordinária nas entrevistas com os docentes. Eduardo inicia a narrativa resumindo sobre os números que o Departamento tem levantado acerca da evasão e repetência de alunos. Esses dados são separados por grupos de cotas, a fim de permitir a visualização do todo sobre a evasão, a desistência e a repetência dos alunos.

\section{Excerto 33: "isso é muito pior do que não entrar"}

1 eu acho que é uma investigação cinúrgica que a gente tem que fazer 2 (1.0) pra=pra mostrar claramente esses números porque senão a 3 gente fica (.) com uma falsa impressão (.) de que é política de cotas 4 é uma política acertada (2.0) né (1.0) eu acho que da forma como ela 5 foi implementada (1.0) a forma como ela foi criada (.) ela NÃO vai 6 resolver o problema (3.0) com a chance maior até de piorar (1.0) 7 porque imagina um aluno que entra aqui (1.0) a duras penas (1.0) e

Eduardo 8 não consegue permanecer (2.0) isso é muito pior do que não entrar

9 (1.0) na minha avaliação (.) muito pior o mal eu acho que é muito 10 maior (2.0) porque além da falta de capacidade de acompanhamento 11 do curso (1.0) entra a frustração de você ser expulso da escola (1.0) 12 entendeu (3.0) por outro lado você permanecer com esse aluno aqui 13 por quanto tempo (1.0) né (.) por exemplo se não existisse o 14 jubilamento talvez esse cara saísse só depois do oitavo ano (1.0) 15 imagine (.) isso é pior ainda (.) do que sair no início (.) entendeu 
Há uma grande avaliação encaixada da linha 3 à linha 6 do resumo da narrativa de Eduardo ("senão a gente fica com uma falsa impressão de que é política de cotas é uma política acertada né eu acho que da forma como ela foi implementada a forma como ela foi criada ela não vai resolver o problema com a chance maior até de piorar"). Nessa avaliação encaixada, o docente julga a política de cotas como um erro, considerando a "forma" como ela foi implementada. Não fica claro à que "forma" o professor se refere, mas acredito que seja em relação primeiro à imposição da política na instituição de modo abrupto, tendo o departamento que retirar o edital já em circulação com inscrições realizadas.

Do mesmo modo, ele também elabora a ideia de que forma a política em si foi "criada" e entendo que ele esteja realizando uma crítica mais ampla em relação às defasagens da educação brasileira de base fundamental, discurso esse já visto aqui em análises de outras narrativas. A grande avaliação que ele realiza nesse ponto da narrativa está em dizer que a cota não vai resolver o problema, mas pode piorar tudo. O que Eduardo significa como problema é a democratização do ensino federal de qualidade a todas as minorias do país, como ele mesmo cita em outros trechos da entrevista. A ideia de que a política de cotas acabará por piorar a situação é mais uma estratégia retórica que indica o pessimismo, tendo em vista a ameaça com um futuro temível.

A partir de então, já feitas essas avaliações, Eduardo segue para a sua pequena ação complicadora, nas linhas 7 e 8 ("imagina um aluno que entra aqui a duras penas e não consegue permanecer"). Na ação complicadora, aparece uma história imaginária produzida pela concepção do pessimismo, imputando ao aluno de modo imaginário tanto a entrada "a duras penas" do aluno na escola quanto a sua impossibilidade de permanência.

Logo na linha 8, ele retorna a avaliar, na avaliação (LABOV, 1972) de sua narrativa, com o mesmo ideal que desenvolveu ao início do seu discurso. Ideal este que gira em torno do quão "pior" é a política de cotas existir, tendo o docente utilizado repetidamente o item de alta gradação "muito pior" (L8 e L9) para dar força a sua concepção sobre a política. Prossegue na mesma linha utilizando mais um item de alta gradação, dizendo que é "muito maior" o mal causado pelas cotas. $O$ adjetivo substantivado "mal" define a política de cotas como Eduardo a concebe em seu discurso.

Ainda na avaliação (LABOV, 1972) de sua narrativa, Eduardo constrói o aluno como incapaz de acompanhar o curso, na linha 10 ("falta de capacidade de acompanhamento do curso"), realizando, então um Julgamento de estima social (MARTIN; WHITE, 2005; NÓBREGA, 2009; WHITE, 2004) sobre sua 
(in)capacidade. Continua a narrativa avaliando como "frustração" (L11) o sentimento que a política de cotas causa no aluno, já que ele não é capaz de acompanhar o curso para o qual passou. Em seguida, personifica a escola ao dizer que o aluno, representado pelo item "você", é expulso por não ter seguido o curso com a escola.

$\mathrm{Na}$ linha 12, ainda dentro da avaliação (LABOV, 1972) de sua narrativa, Eduardo inicia outro ponto de vista sobre o que está falando, indicado pelo item "por outro lado". Porém, o item indica a adição de mais uma perspectiva negativa sobre as cotas, somente, e não a mudança para alguma concepção positiva sobre ou para o aluno "cotista", como o termo preveria. O professor indica que, se o jubilamento ${ }^{44}$ for extinto, a escola não teria ganhos sobre o aluno, pois ele permaneceria por oito anos no CEFET/RJ. A priori ele parece estar preocupado com o aluno, quando em sua coda ("isso é pior ainda do que sair no início, entendeu", L15) diz que é pior o aluno ter mais chances de permanência. Porém, em se tratando de tudo que ele falou ao longo de sua narrativa, entendo que o uso do item de alta gradação "pior ainda" (L15) indique que ele esteja se referindo à escola e à perda de algo relacionado à escola, em consonância com o mesmo termo (pior) usado ao início de sua narrativa.

Com uma ideia bastante parecida, a narrativa de Afonso, no excerto 34 expõe a "preocupação" com o mal que a política de cotas pode fazer ao aluno. Afonso vinha falando sobre o resultado de uma prova de nivelamento realizada pela sua coordenação para que os docentes, junto ao DEMET, pudessem construir um plano melhor direcionado aos alunos que tivessem maior defasagem de conteúdos no primeiro ano.

\footnotetext{
44 Jubilamento é o termo utilizado pela comunidade escolar do CEFET/RJ para o artigo do regimento interno escolar que versa sobre o cancelamento da matrícula do aluno que repetir o ano duas vezes consecutivas. Cabe salientar que, no momento da entrevista, a possibilidade de extinção do jubilamento estava em pauta no CONDMET, com o encaminhamento da maioria dos docentes representantes votando pela sua extinção. O professor faz, então, uma crítica direta sobre esse encaminhamento para o fim do jubilamento, sendo ele contra a extinção do mesmo.
} 
Excerto 34: "era o grande mal que a gente estaria fazendo colocando o aluno aqui"

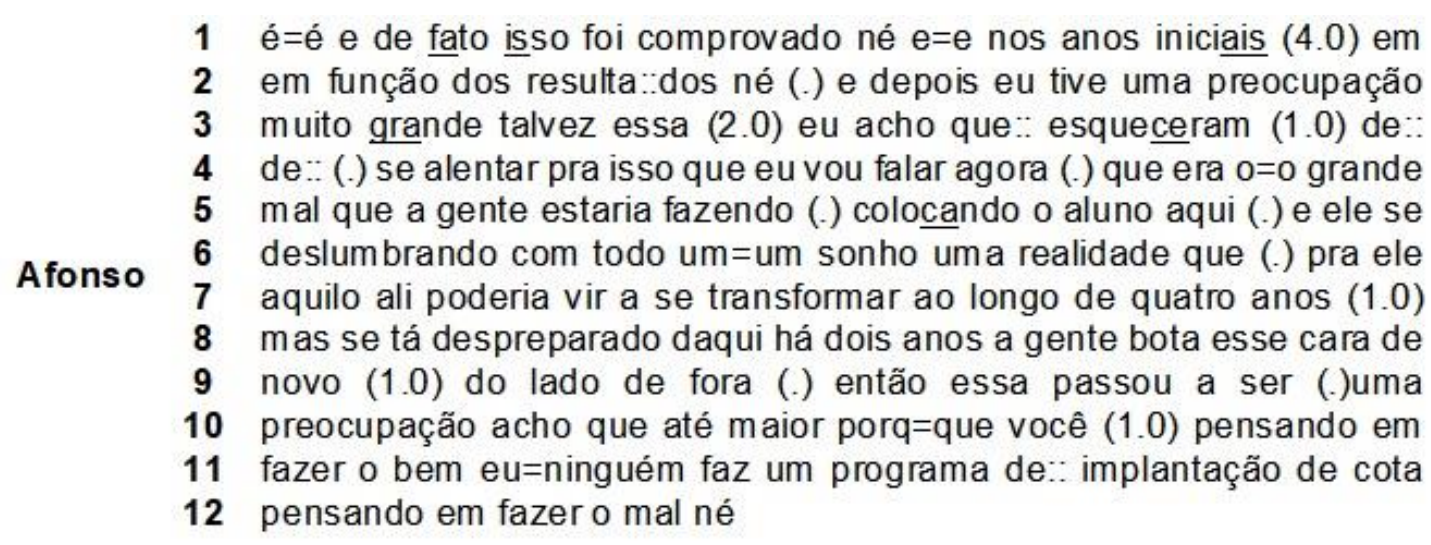

Afonso anuncia a sua preocupação logo no resumo de sua narrativa, nas linhas 2, 3 e 4 ("eu tive uma preocupação muito grande talvez essa eu acho que esqueceram de=de se alentar para isso que eu vou falar agora"). A partir desse ponto, na linha 4, o professor inicia a ação complicadora que, assim como na narrativa do excerto 33 de Eduardo, prenuncia a catástrofe que a política de cotas pode trazer ao aluno "despreparado" (L8). Afonso usa o item de alta gradação "grande mal" (L4 e L5), que avalia a situação da cota para o aluno "cotista".

A partir de então, vale ressaltar o item "colocando", metáfora que traz a ideia de que o aluno "cotista" não realizou prova de concurso como os demais, e direcionando para o entendimento do que a própria palavra diz em seu sentido literal. Ao dizer que estaríamos "colocando" o aluno, está implícita a imagem simbólica de que alguém colocou o aluno no CEFET/RJ, sem certame público. Isso também traz a este "alguém" o poder de "colocar" o aluno dentro da instituição. Creio que isso possa representar o dono da vaga (não cotista em geral e professores, ou seja, a instituição) que "coloca" o "cotista" na vaga que lhe é cedida ou doada, e não o aluno que entra na escola.

Junto à estratégia de pessimismo que apresentei nas narrativas acima, foi possível encontrar mais um meio de realização da construção discursiva de estigmas nas narrativas dos docentes. As denotações e metáforas depreciativas (WODAK et al., 2009) fizeram também parte dessas construções. Porém, correndo o risco de parecer descontextualizar as histórias, opto por disponibilizar apenas pedaços das narrativas, e não elas inteiras, para exemplificar a forma como as metáforas constroem características depreciativas para os alunos.

No excerto 35, Ana desenvolve a ideia de que o aluno "cotista" entra no CEFET/RJ sem sequer conseguir fazer conta (L2) e que a instituição é 
responsável por transformar o aluno em dois meses (L3 e L4) em alguém que consegue realizar uma prova e se comportar direito, conforme exponho abaixo.

\section{Excerto 35: "o cara não sabe nem fazer conta e tá aqui no CEFET/RJ"}

1 o que eu vi essa galera (.) é (.) com o mesmo preconceito de repente que

2 eu ti:.ve (.) porra lá "o cara não tem não sabe nem fazer conta e tá aqui no Ana 3 no cefet $^{n}$ e ver esse garoto crescer (.) crescer muito no final daqui a do is

4 meses o cara já tá le::ndo tá falando be::m tá fazendo uma boa pro::va tá se

5 comportando dire::ito tá correndo atrá::s

O preconceito a que ela se refere na primeira linha é sobre o aluno que não "sabe nem fazer conta" (L2) e não sobre a fala dela fazendo a construção de um aluno analfabeto. Essa me parece ser uma avaliação de estima social (MARTIN; WHITE, 2005; NÓBREGA, 2009; WHITE, 2004) que aponta para a (in)competência do aluno.

Entendo que quando Ana utiliza o termo "crescer" (L3) duas vezes, adicionado ao item de alta gradação "muito" (L3), por oposição, ela está dizendo que o aluno "cotista" ainda não cresceu. Isso coloca o aluno em posição inferior aos demais alunos, fazendo uma metáfora depreciativa sobre o "cotista". Há nesse ponto um Julgamento de estima social (MARTIN; WHITE, 2005; NÓBREGA, 2009; WHITE, 2004), com a avaliação da evolução do nada para o crescimento do aluno. Ela faz o mesmo quando conta a história de que em dois meses "o cara" (L4), item que marca o distanciamento dela com os alunos, evolui após a sua permanência na escola.

Para construir essa evolução, Ana realiza uma gradação de ideias estigmatizantes sobre o aluno "cotista" que se ordena da seguinte forma: $1^{\circ}$ - "já" está lendo; 2-. "tá" falando bem; 3- "tá" fazendo uma boa prova; $4^{\circ}$ - "tá" se comportando direito; 5-. "tá" correndo atrás (L4 e L5). Essa enumeração de evoluções que Ana descreve traz a sugestão da existência da diferenciação cronológica entre a entrada do aluno na escola e o resultado do caminho que ele percorreu em dois meses. O item "tá", que demarca o início de cada enumeração que a docente faz, marca a passagem de tempo, indicando que "agora", após ter sido salvo pelo CEFET/RJ, o aluno "tá" realizando tudo que ela lista.

Vale ainda atentar para os estigmas criados na narrativa de Ana, que indicam que o aluno não havia nada do que ela lista como construção após os dois meses na escola. Por oposição, se Ana diz que somente após esse tempo ele consegue realizar tudo aquilo, ela está dizendo que o aluno "cotista" entra na 
escola ainda sem ler, sem saber fazer uma boa prova, não sabendo se comportar direito e estagnado por não correr atrás. Todos esses estigmas são construídos no discurso de Ana pelo Julgamento de estima social (MARTIN; WHITE, 2005; NÓBREGA, 2009; WHITE, 2004) e reforçam o Discurso sobre a inferioridade esperada para o aluno que acessa o CEFET/RJ pela política de cotas.

Não é diferente o que o docente Edson realiza em sua narrativa, durante a entrevista de pesquisa, a qual apresento no excerto 36 .

\section{Excerto 36: "salvar aqueles que quase não têm chance nenhuma"}

1 ou:: o menos fraco né (2.0) mas aí=é é assim aí a questão especí:fica

2 das cotas né (2.0) realmente é é difícil (1.0) né é difícil porque a gente

Edson 3 tem que dar (.) assim tem que dar uma (.) é=é tem que buscar salvar 4 aqueles que quase não têm chance nenhuma lá fora (2.0) né é eu vejo 5 assim (.) tem que tentar salvar

Na linha 2, Edson utiliza duas vezes o item de avaliação com alta gradação "difícil", que indica seu posicionamento frente à entrada dos alunos "cotistas" na escola. Nesse momento de avaliação sobre suas emoções, o docente entra no campo semântico do Afeto (MARTIN; WHITE, 2005; NÓBREGA, 2009; WHITE, 2004). A ênfase que Edson dá por meio desses itens dá força à ideia de que a presença dos novos alunos na escola o retira da normalidade, que é representada em oposição por algo, então, fácil. Passa a ser "realmente" (L2) difícil a situação com a entrada dos alunos "cotistas" no CEFET/RJ.

A ideia de dificuldade trazida pelo aluno é completada com a construção de salvamento que recai sobre o docente e a instituição, quando ele utiliza o termo "a gente tem que dar" (L2 e 3) e o repete na linha 3 ("tem que dar"). O verbo "dar" direciona ao sistema de coerência de senso comum, que posiciona a instituição e os componentes nela inseridos como detentores de poder e permissão do que se pode dar, como já visto em outras narrativas. Do mesmo modo, o item "salvar" (L3 e L5) também indica o local de poder que o docente se coloca, levando à ideia de que ele, como docente e representante da instituição, é o salvador dos alunos "cotistas".

Em seguida, Edson avalia os alunos como "aqueles que quase não têm chance nenhuma lá fora" (L4). Esse é um estigma criado discursivamente sobre o aluno "cotista", que traz a ele a idealização de uma vida inexistente fora da escola. "Lá fora" (L4) denota, também, a segregação simbólica entre o CEFET/RJ e o restante da sociedade, que não tem o mesmo poder que o CEFET/RJ tem de 
salvar o aluno, tendo em vista que "lá fora" ele não tem chance "nenhuma". Ou seja, tendo usado o item "nenhuma", Edson indica que não existe possibilidade de "salvação" fora da escola, o que atribui ao aluno a ideia já discutida nesta tese sobre aproveitar a chance que é "dada" ao "cotista".

Mais exemplos de metáforas depreciativas usadas no discurso dos docentes entrevistados em minha pesquisa aparecem na narrativa de Luciano, que apresento no excerto 37 .

Excerto 37: "mesmo que ele bata a cabeça pra lá e pra cá"

\begin{tabular}{|c|c|c|}
\hline Luciano & 2 & rdo (10) nã =é \\
\hline & 3 & com a politica de cotas você concorda \\
\hline Luciano & $\begin{array}{l}4 \\
5 \\
6 \\
7 \\
8 \\
9 \\
10 \\
11 \\
12 \\
13 \\
14 \\
15 \\
16 \\
17 \\
18 \\
19\end{array}$ & 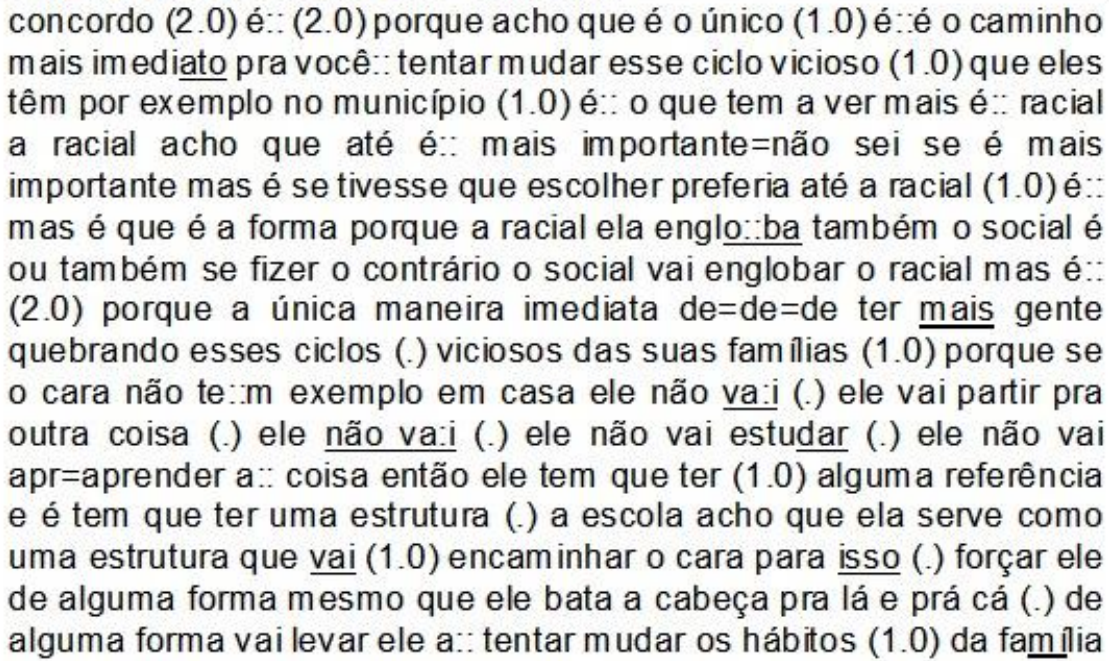 \\
\hline
\end{tabular}

Luciano utiliza o item modal "acho", na linha 4, que mostra o baixo grau de comprometimento (HALLIDAY, 1985) na resposta à pergunta direta que eu faço sobre cotas. Outro indício de receio em responder está na hesitação em responder, como está marcado internacionalmente na linha 2 ("concordo, não é"). Em seguida, o professor avalia como "ciclo vicioso" (L5) o que ele descreve em sua narrativa como o ciclo em que o aluno "cotista" ou do município se encontra por estar inserido em situação familiar desestruturada e sem referência. Este é um julgamento de sanção social (MARTIN; WHITE, 2005; NÓBREGA, 2009; WHITE, 2004) que ajuda a construir o estigma do aluno "cotista" como inserido em uma organização desestabilizada dentro de sua família. É uma denotação depreciativa que não só generaliza as situações familiares dos alunos "cotistas" como ruins, mas que constroem a ideia de que são alunos largados, tendo em vista que 
socialmente espera-se que a família forme bases que solidificam o aluno enquanto cidadão.

$\mathrm{Na}$ linha 6, Luciano realiza a comparação dos alunos "cotistas" com os alunos de município. Nesse ponto não trago esta análise para informar que a comparação é ruim porque o aluno de município é pior do que o aluno do CEFET/RJ, mas para mostrar como estruturas de senso comum são criadas através das experiências pessoais dos professores. Dessa forma, isso recai sobre a criação de estigmas que relacionam, em forma de generalizações, comportamentos vistos no município e vivenciados pelo docente que fazem com que as expectativas dele sejam transferidas para o momento da recepção dos alunos "cotistas" no CEFET/RJ, reforçando os estigmas supracitados.

Mais abaixo, após discorrer sobre sua opinião acerca das cotas raciais e socioeconômicas, Luciano retorna a dizer que existem ciclos viciosos (L12) que precisam ser quebrados. O item "quebrando" (L12) indica que é esperado que este ciclo seja algo mais rígido, direcionando novamente à ideia da estratégia de pessimismo e à luta árdua ou impossível que o "cotista" enfrenta. Luciano deixa evidente que é da família (L12) à que ele se refere quando aponta os ciclos viciosos e ratifica ao dizer que "o cara" (L13), que distancia o docente do aluno, "não tem exemplo em casa" (L13). Através desse Julgamento de estima social (MARTIN; WHITE, 2005; NÓBREGA, 2009; WHITE, 2004) fica, então, explícito o estigma sobre uma possível desestrutura familiar atribuído ao aluno "cotista".

Mais à frente, Luciano usa o item "alguma" (L15) para dizer que o aluno precisa ter alguma referência. Por exclusão, se ele diz que a escola dá essa referência (L16 e L17), ele também está dizendo que a família não dá, sendo o item "alguma" o indicativo de que, então, não há nenhuma. Para Luciano, a escola "força" (L17) o aluno a tentar mudar os hábitos da família (L19), o que reforça ainda mais a desestrutura familiar esperada para o aluno "cotista". Para descrever mais uma vez a luta árdua que o "cotista" precisa passar, Luciano usa, na linha 18, o termo "bata a cabeça pra lá e pra cá". É uma metáfora que indica certa depreciação da tentativa do aluno de se manter na escola, tendo em vista que ele vai bater a cabeça de um lado para o outro sugerindo que daquele lugar ele não sairá.

Mais um exemplo de metáfora depreciativa presente na construção discursiva do estigma do aluno "cotista" aparece no discurso do professor Jonas, no excerto 38. 
Excerto 38: "bacana pro cotista, pro não cotista, se ferrou"

\begin{tabular}{ccl} 
& 1 & vai afunilando (.) mas o cara que se inscreve aqui (.) e consegue \\
Allane & 2 & pontuação próxima (.) a da ampla concorrência ele é deslocado pra \\
& 3 & ampla concorrência e libera uma vaga \\
\hline Jonas & 4 & ah bacana \\
\hline \multirow{3}{*}{ Allane } & 5 & pra outra pessoa entrar (.) então (.) conforme vão o=o desempenho \\
& 6 & deles eles vão sendo colocados na vaga de ampla concorrência e \\
& 7 & liberam a cota \\
\hline Jonas & 8 & bacana pro ca=pro cotista pro não cotista se ferrou \\
\hline Allane & 9 & o não cotista é (.) vai por porque a gente libera pra dar mais opções \\
& 10 & mas aí ele=[ele] \\
\hline Jonas & 11 & [é] uma visão (.) em pro::I do cotista
\end{tabular}

Em determinado ponto da entrevista, o professor Jonas me questionou como era realizada a divisão de cotas no CEFET/RJ, tendo em vista que o referencial de informação que ele tinha sobre as cotas havia sido as da UERJ, local onde trabalhou por dez anos antes desse dedicar exclusivamente ao CEFET/RJ. Eu explico, então, que o aluno que se inscreve pela política de cotas vai sendo posicionado nas vagas conforme seu desempenho na prova do concurso. Dessa forma, caso ele tenha pontuação alta que se assemelhe às pontuações da ampla concorrência, ele "libera" a vaga das cotas para a qual se inscreveu e é deslocado para a vaga de ampla concorrência.

Jonas primeiro utiliza o termo "bacana" (L4) para avaliar o que eu estava explicando sobre a divisão das cotas. Porém, mais à frente, quando eu finalizo a explicação, Jonas julgou que essa forma de divisão era bacana para os "cotistas", mas não para o "não cotista". Ele conclui sua opinião avaliando que é uma visão em prol do "cotista" (L11). Nesse ponto, em seu discurso, o docente mostra não visualizar benefícios da política de cotas aos demais alunos.

Já com a narrativa de Paloma, no excerto 39, retorno à construção discursiva de estigma pelas denotações depreciativas sobre os alunos "cotistas". Paloma apenas inicia a ação complicadora de sua narrativa na linha 9, quando começa a contar a história de Marcos. Antes disso, ela trata do ensino técnico como agente social que encaminha os alunos após eles entraram no CEFET/RJ do "jeito que chegaram" (L8), conforme pode ser visto a seguir. 


\section{Excerto 39: "ele é muito mais educado hoje"}

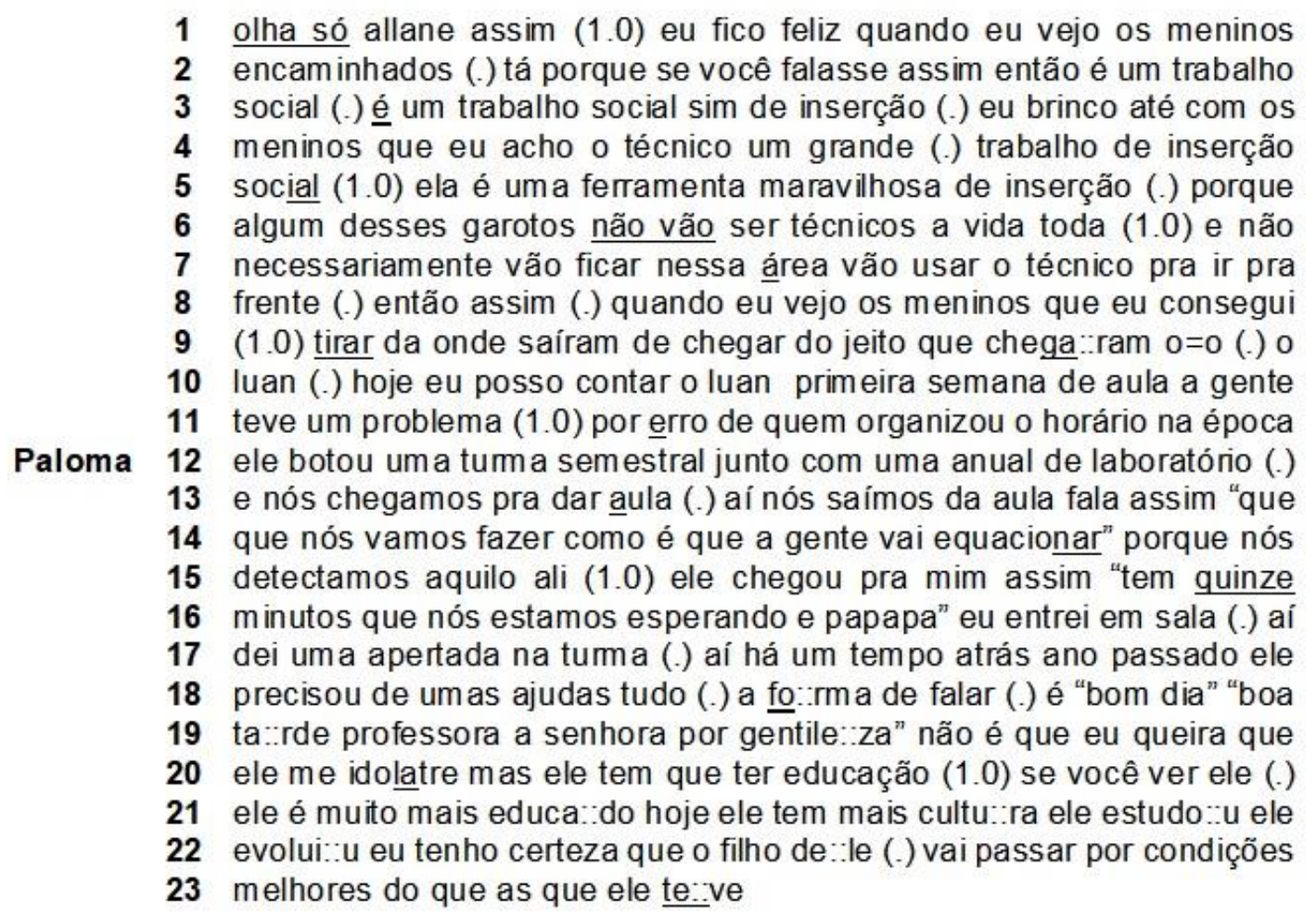

Antes de iniciar a análise da história que Paloma conta na ação complicadora, vale destacar a forma como ela se constrói como heroína dos "meninos", nas linhas 8 e 9 ("eu vejo os meninos que eu consegui tirar de onde saíram de chegar do jeito que chegaram"). Ao mesmo tempo em que ela se coloca como a única responsável pela salvação dos alunos quando usa os termos "eu consegui tirar" (L8 e L9), ela acaba se distanciando deles mesmos quando utiliza o termo "meninos" (L8).

Quando Paloma começa a narrar a história de Marcos, na ação complicadora (L10 a L19), contando que, no primeiro dia de aula, o aluno foi ríspido com ela diante de seu atraso de quinze minutos. A docente primeiramente justifica que o atraso se deu por conta de um problema de organização de horários de turmas, o que chocou duas turmas de ciclos diferentes e, assim, justificou para mim o atraso que estava na história que ela ia contar naquele momento. Paloma reporta a fala de Marcos nas linhas 15 e 16 ("tem quinze minutos que nós estamos esperando") e isso se liga ao que ela havia dito logo anteriormente nas linhas 13 e 14 ("que que nós vamos fazer, como é que a gente vai equacionar").

Nesse ponto da narrativa de Paloma, o que ela está dizendo pelo item "equacionar" (L14) é que a reclamação de Marcos sobre o atraso ou a forma como ele fala (o modo como ela prosodicamente constrói essa fala indica que ele foi ríspido) não estão em equilíbrio com o que ela estava acostumada no CEFET/RJ. 
Além de ser uma avaliação de estima social (MARTIN; WHITE, 2005; NÓBREGA, 2009; WHITE, 2004), o que Paloma está trazendo em sua narrativa quando diz isso, é a construção de uma característica negativa, como pode ser visto em muitas narrativas nas análises deste capítulo. Essas denotações depreciativas fazem parte da construção de estigmas que acabam por aparecer nas histórias que os docentes contaram nas narrativas das entrevistas.

Para traçar a mudança de comportamento e talvez o equilíbrio que Paloma sugere que a escola traz aos alunos, ela termina a ação complicadora de sua narrativa marcando cronologicamente que "um tempo atrás" (L17), Marcos a procurou, pois precisava de ajuda. Ela descreve como o aluno modificou sua conduta de falar e de abordá-la com "tudo é a forma de falar", acrescido dos itens "bom dia", "boa tarde", "senhora", "por gentileza" (L18 e L19). Todos esses itens são utilizados por Paloma para identificar o marco da mudança que ela e a escola trouxeram aos "cotistas" e como esses elementos são centrais ou quase únicos nessa mudança.

$\mathrm{Na}$ coda avaliativa que a docente realiza, das linhas 19 a 23, ela se justifica novamente dizendo que a sua exigência não é uma busca por idolatria, mas que o aluno tenha educação. A partir de então, entendo que ela esteja dizendo que o aluno, até então, não tinha educação. Entendo, também, que ela esteja significando o termo "educação" com algo relacionado a comportamento e modo de falar que ela julga como corretos. Ela termina realizando uma gradação sobre a evolução desse aluno das linhas 21 a 23 , e julga que, após essa mudança, os filhos desse aluno no futuro terão melhor condição do que ele mesmo teve. A gradação se dá na seguinte ordem: $1^{\circ}$ - ele é muito mais educado hoje (culminância); $2^{\circ}$ - ele tem mais cultura (culminância); $3^{\circ}$ - ele estudou (processo da evolução); 4º- ele evoluiu (culminância). Há um Julgamento de estima social (MARTIN; WHITE, 2005; NÓBREGA, 2009; WHITE, 2004) realizado por Paloma.

Essa construção também leva à ideia de que já que Marcos chegou ao CEFET/RJ "sem ter educação", a sua família também não tem educação, considerando que, para ela, agora que ele tem educação seus filhos também terão condições melhores no futuro. Sendo assim, mais uma vez aparece nas narrativas a construção de metáforas depreciativas não só para os alunos mas extensivo aos componentes familiares desses alunos. A família, além de desestruturada, não "tem educação", assim como os "cotistas". 


\subsection{1. Conclusões da seção}

Os itens que constroem a estratégia de pessimismo vêm reforçar que essa luta impossível dos alunos constrói fraqueza sobre a política de cotas, já que não se há onde chegar após tantas impossibilidades. Sendo assim, a existência da política é questionada a partir de discursos que reforçam a ideia de que é uma política que, ao final, "atrapalha" e "destrói" a autoestima dos próprios alunos "cotistas".

Transpus a ideia de descrédito de Wodak et al. (2009) para esta tese como apontamento de como todas as construções sobre os "cotistas" giram em torno da negativação, não somente deles mesmos enquanto sujeitos, mas de tudo que envolve os processos relacionados a eles. É uma das formas de deslegitimar a política, uma vez que está sendo atribuído às consequências dela aos próprios alunos que acabam por serem construídos como oponentes da própria evolução na escola.

Para que o objetivo oculto de desacreditar a política de cotas ocorra de modo exitoso nas narrativas, a forma mais fluida de reduzi-la a um problema é na construção das características dos sujeitos "cotistas". Isso ocorre, então, discursivamente pelas metáforas e denotações depreciativas, que acabam por ratificar diversos estigmas sobre os alunos, para além de somente descreditar a política de cotas. A partir dessas construções, os alunos absorvem todas as construções negativas sobre eles e esses estigmas são reproduzidos em várias outras histórias, como pode ser visto nas narrativas dos docentes neste estudo. Essa é a atualização do Discurso geral sobre cotas e sobre os alunos que da política usufruem. Para melhor ilustrar os resultados desta seção, apresento o Esquema 7: 
Esquema 7: Relação entre os estigmas, narrativas e modos de realização discursiva

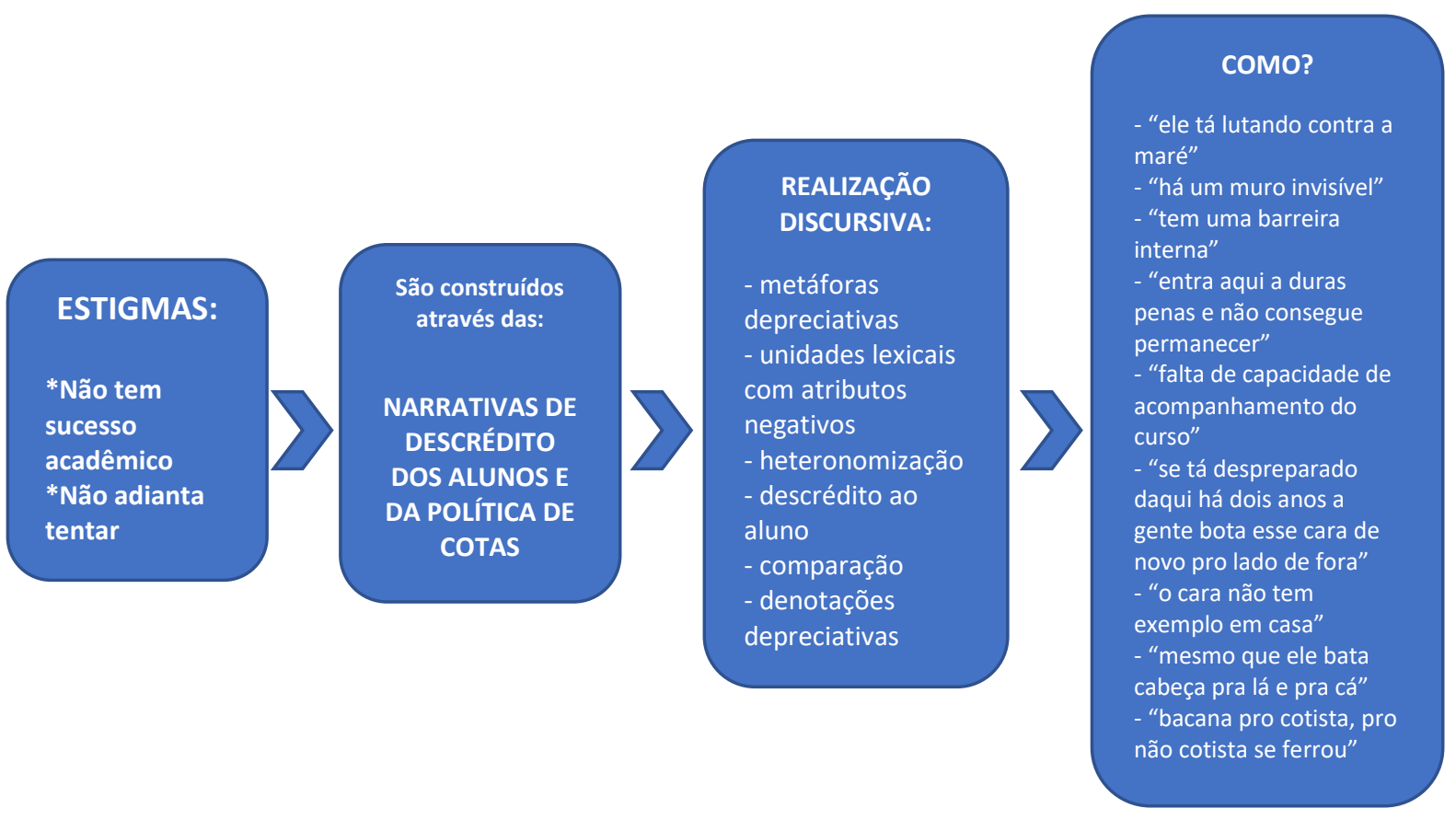

Fonte: Elaborado pela autora (2020).

Apresentadas as análises sobre o descrédito aos alunos e à política de cotas, caminho para a última seção deste capítulo (5.6.) que desenvolve a ideia da consequente construção discursiva da descontinuação da política.

\section{6.}

Narrativas de descontinuação da política de cotas

Como última a ser discutida e localizada nas narrativas, trago sob a ideia de Wodak et al. (2009) as narrativas de descontinuação da política de cotas. Novamente aparecem topos sobre o tempo, incluindo o histórico como professor que dá autonomia aos docentes para validação sobre o que eles dizem nas histórias. Portanto, há a ênfase sobre as diferenças entre o antes, o agora e o futuro. Como meios de realização no discurso, essa ênfase cronológica se dá pelos modais deônticos normativos, como "tem que" usado diretamente ou a ideia evidente de compulsoriedade. Outra ideia que se manifesta nas narrativas que analiso neste momento é a concepção de que "uma crise é também uma chance" (WODAK et al., 2009), que trazem questionamentos sugestivos. 
Nesta seção, trago narrativas não canônicas, pequenas e que de modo rápido mostram os meios de realização da estratégia de descontinuação da política de cotas. Nessas narrativas, são encontrados os itens e as ideias que eles passam sobre a cronologia que legitima as histórias que contam os caminhos de mudanças compulsórias em diversos âmbitos após a política de cotas. Vale lembrar que essas histórias de mudanças, mesmo que travestidas de positivas para a escola, formam base para a construção de estigmas sobre cotas. Para iniciar a análise dessa estratégia retórica, trago a pequena narrativa do professor Marcelo, no excerto 40.

\section{Excerto 40: "ele se acostumou com o aluno nota dez"}
Marcelo
1 eu acho que (.) $0=0$ problema o que que afe :ta o professor (1.0) é 2 porque o nosso professor ele se acostumou (.) com o aluno nota dez 3 (1.0)_ sempre foi assim (1.0) quem ve:.io de outras instituições pra 4 cá:: (.) vê diferente (1.0)

A narrativa de Marcelo tem apenas a ação complicadora ("eu acho que o o problema o que que afeta o professor é porque o nosso professor ele se acostumou com o aluno nota dez sempre foi assim") e uma coda avaliativa ("quem veio de outras instituições pra cá viu diferente"). Marcelo diz que o problema que afeta o professor é a quebra no costume que havia em receber alunos, segundo ele, "nota dez". Sempre chamamos internamente esses alunos de alunos prontos, pois não necessitam de preparo extra algum para percorrer a trajetória acadêmica dentro do CEFET/RJ, não importando o nível de exigência que a escola aplique sobre ele. Marcelo avalia a estima social (MARTIN; WHITE, 2005; NÓBREGA, 2009; WHITE, 2004) do aluno com o termo "nota dez" definindo o quão ele é capaz.

O termo que Marcelo utiliza, aluno "nota dez", indicia o aluno "cotista" como o aluno que não é "nota dez". Vale ainda ressaltar a construção problemática em relacionar o aluno bom, seja ele qual for em geral, com o aluno que tira nota dez. É uma relação numérica que desconsidera as avaliações qualitativas da formação do aluno, o que vai de encontro aos preceitos da formação integral que não só o CEFET/RJ preconiza em seus planos pedagógicos de curso $^{45}$, mas o que os

\footnotetext{
${ }^{45}$ Após minha transferência da DIAPE para o DEMET (departamento que chefia a DIAPE), uma das primeiras responsabilidades que tive foi a elaboração dos Planos Políticos de Curso (PPC) para os 11 cursos existentes no segmento de Ensino Médio e Técnico (na época, antes da modalidade integrada de ensino). Junto aos coordenadores de curso, eu fui a autora/coordenadora e revisora de todos os PPCs.
} 
estudos em educação como um todo indicam como parâmetro de filosofia educacional.

Essa parece uma construção comum feita pelos docentes da área técnica, tendo em vista que um grande número de professores do núcleo técnico não passou pela formação de licenciatura. $O$ concurso para docente efetivo no CEFET/RJ e para as vagas de docência federal de ensino técnico não tem como exigência a formação em licenciatura, podendo, por exemplo, um engenheiro ministrar aula das disciplinas técnicas, sem ter tido formação docente para tal.

Apesar da possível diferenciação entre as formações pedagógicas dos professores dos dois núcleos do CEFET/RJ, ao longo da entrevista para esta pesquisa, Marcelo relata exemplos de trabalhos que ele realizou que foram direcionados por metodologias de avaliação qualitativa que não encontro, por exemplo, em disciplinas do núcleo básico. Ainda assim, ele utiliza o termo aluno "nota dez", em alinhamento a princípios de avaliação quantitativa dos alunos que acaba por selecionar e separar, de modo equivocado, os alunos em "alunos bons" e "alunos ruins".

Nesse sentido, Marcelo cria o índice de aluno bom que não inclui os alunos "cotistas", já que em sua história os professores estão acostumados com os alunos "nota dez" que são os existentes, teoricamente, antes do atendimento à política de cotas no CEFET/RJ. Por oposição, assim, após a política de cotas, os alunos não são mais aqueles aos quais os docentes estão acostumados, ou seja, não são alunos "nota dez", direcionando à ideia de que os "cotistas" são, agora, alunos inferiores.

Sua coda avaliativa diz que os docentes que chegaram de outras instituições não perceberam essa mudança ou não sentiram esse ponto fora de seu costume. Marcelo julga como "diferente" a experiência supostamente vivida pelos docentes que chegaram após as cotas e que vieram de outras escolas. Dessa forma, ele destaca o CEFET/RJ das demais escolas que existem no Rio de Janeiro, posicionando-o como de melhor qualidade do que outras escolas, o que constrói, também, uma identidade assimétrica diferenciada para o CEFET/RJ.

Na narrativa de Marcelo, a comparação ganha o viés cronológico a partir do ponto em que ele indica, através do verbo "acostumou" (L2), a delimitação entre o antes e o agora. Ali ele posiciona cronologicamente uma coisa boa no passado e transfere ao presente a coisa ruim: a cota. Na narrativa de Eduardo, no excerto 41, também encontro esse padrão de delimitação entre o antes e o agora, mas que o docente acaba por se contradizer ao tentar se retirar da possibilidade de 
uma avaliação sobre os novos alunos de cotas que possa ser entendida como ruim, conforme podemos ver abaixo.

Excerto 41: "pra mim não alterou nada"

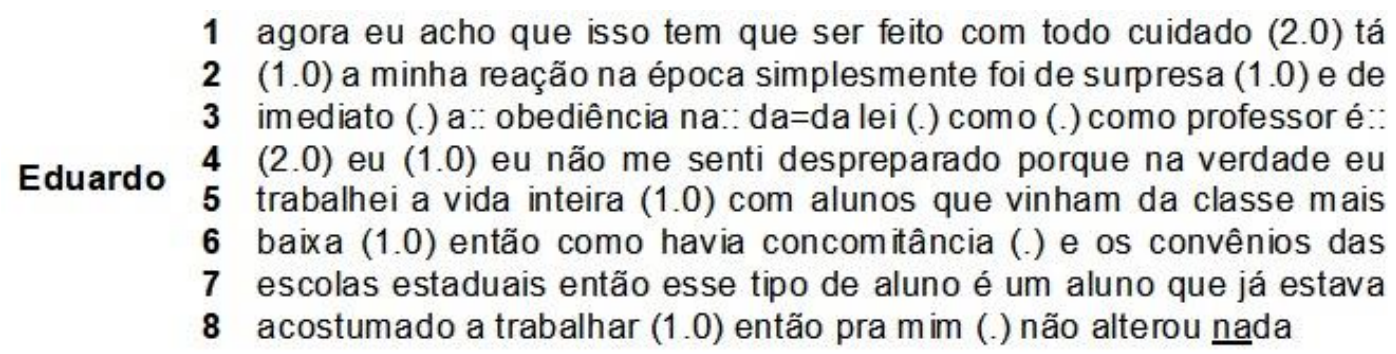

A título de entendimento do contexto de entrevista, Eduardo vinha falando sobre o cuidado que deveríamos ter ao analisarmos os dados sobre os alunos "cotistas" no CEFET/RJ, que ainda se encontrava, até aquele momento, em posse apenas da equipe pedagógica do DEMET. Dados esses relativos à pontuação de entrada, desempenho escolar e evasão. Em seu resumo (L1), ele mostra essa preocupação e logo inicia, na mesma linha, a ação complicadora de sua narrativa. Nela, ele conta como foi a sua reação ao saber que os alunos entrariam pela política de cotas a partir de 2013 , em resposta à pergunta que eu havia feito na entrevista.

Eduardo discorre sobre a "surpresa" (L2) que o tomou de "imediato" (L3) e o termo "obediência" (L3) à lei mostra a obrigatoriedade sobre a qual discuti na seção anterior, que coloca o docente na posição de destino inexorável em seu trabalho. Porém, de forma controversa, ele modifica o padrão do que havia dito, indicando que já estava acostumado com "esse tipo de aluno" (L7) e que, por isso, não se sentiu "despreparado" (L4). Quando Eduardo usa o termo "esse tipo de aluno", ele está realizando um Julgamento de estima social (MARTIN; WHITE, 2005; NÓBREGA, 2009; WHITE, 2004), que não somente o afasta dos alunos "cotistas", mas solidifica o afastamento geral deles, como se criasse uma barreira entre os alunos "cotistas" e os demais integrantes da escola.

Assim, em sua ação complicadora, ele desenvolve primeiro a surpresa, que o coloca no estado de percepção de algo diferente entre o antes e o agora, mas depois ele transcorre a história indicando o oposto, qual seja, que não houve modificação alguma para ele, conforme verbaliza em sua coda ("então pra mim não alterou nada"). Entendo essa contradição como um ajuste interacional, sabendo o docente exatamente do que trata a pesquisa. 
Sendo assim, o distanciamento de Eduardo com os alunos de "classe mais baixa" (L5 e 6) desponta na linha 7, como já discuti acima, ao dizer que ele estava acostumado a trabalhar com "esse tipo de aluno". E ao exprimir que esse tipo de aluno é de classe mais baixa esses itens são direcionados, por oposição estabelecida cronologicamente entre o antes e agora, ao aluno "cotista". Sendo assim, consigo identificar que a surpresa que o professor sentiu foi exatamente sobre o aluno que acessaria o CEFET/RJ pela política de cotas, e é dele de quem Eduardo está falando.

A próxima narrativa de Ana nos mostra como é construída a ideia de que com a crise todos evoluem em conjunto. Essa narrativa é a continuação do excerto 22, já analisado neste capítulo, quando busquei entender o discurso dos estigmas criados pela estratégia de engajamento docente (WODAK et al., 2009). Assim, Ana continua a entrevista iniciando outra narrativa, após avaliar que a política de cotas não deveria aguardar as modificações sobre o ensino fundamental no Brasil, conforme excerto 42.

\section{Excerto 42: "Foi um aprendizado eu acho que pra todo mundo"}

1 bom eu acho que (.) que se esperar o momento ce:: rto o momento ideal 2 pra que (.) ah pessoal fala né "vamos esperar vamo primeiro trabalhar a 3 educação infantil e (.) fundamental pra daí:. o cara chegar no ensino 4 médio preparado" é besteira isso (.)

\begin{tabular}{ccl}
\hline Allane & $\mathbf{5}$ & não vai... nunca chega a esse momento [né] \\
\hline & $\mathbf{6}$ & \\
& 7 & formando aí:. (.) já tem uns (.) é grupos se formando e assim (.) em \\
Ana & $\mathbf{8}$ & quatro anos os garotos num =não tem diferença nenhuma pra quem é \\
& 9 & cotista pra quem não é cotista em no:.ta (.) e.: (.) e foi um aprendizado \\
& 10 & eu acho que pra todo mundo
\end{tabular}

Dessa vez, sob a mesma ótica do engajamento analisada na seção 5.3. deste capítulo, volto o foco para a sugestão de que todos aprendem juntos com a entrada da política de cotas. É evidente que essa é uma construção com um direcionamento mais positivo sobre cotas que a docente lança sobre sua história. O que não é percebido são os estigmas criados a partir dessa ótica, em especial pela forma como Ana descreve cronologicamente a mudança de estado do aluno de sua entrada e da sua saída após os quatro anos de formação.

Ana constrói a gradação de evolução do aluno "cotista" pela escolha do item "em quatro anos", que indica um determinado espaço de tempo em que, então, desaparece a diferença entre o "cotista" e o "não cotista". O que ocorre é que, com essa escolha lexical, Ana está criando um índice sobre o aluno "cotista" como o 
aluno que entra em patamar diferente dos demais alunos. Assim, é reforçado o estigma de aluno inferior sobre o "cotista", estabelecendo a assimetria entre os próprios alunos.

$\mathrm{Na}$ linha 9, Ana ainda deixa claro que os alunos conseguem se igualar "em nota", o que leva ao entendimento de que, sob as demais características, não há mudança significativa a ponto de ser relatada em sua narrativa. No excerto 43 , mostro a narrativa de Vicente, que elabora a necessidade de mudança a partir de itens claros que delimitam diferenciação entre alunos.

\section{Excerto 43: "você tem que nivelar"}

\begin{tabular}{lll} 
Allane & $\mathbf{1}$ & quando começou né (.) e cê teve que fazer alguma modificação com a \\
& $\mathbf{2}$ & ou com a maté:: ria com a parte de ensi::no \\
\hline & $\mathbf{3}$ & Sim a gente tem que adaptar né você tem que nivelar (.) é você não \\
$\mathbf{4}$ & pode falar (.) no nível do:.:do melhor aluno nem no nível do pior aluno \\
$\mathbf{5}$ & você tem que pegar e dar uma=uma equilibrada ne (.) e eu sentia que \\
Vicente & $\mathbf{6}$ & tinha muitos alunos avancados né (.) e: (.) até no excel que já tinham \\
$\mathbf{7}$ & feito curso (.) eutros alunos que estavam atrasados entấo eu tive que \\
$\mathbf{8}$ & (.) tipo assim (.) separar em du:.:pla nosso laborató:rio não sei se você \\
$\mathbf{9}$ & conhe:ce
\end{tabular}

Eu direciono a pergunta a Vicente perguntando se ele teve que fazer alguma modificação em relação às matérias que ele ministra em sua disciplina e Vicente relaciona diretamente aos alunos. O que o docente faz é atribuir ao aluno o motivo de ter que modificar a metodologia de ensino em sua disciplina. Em momento algum ele diz que modificou a estrutura curricular, ou pontos do conteúdo programático, mas conta que modificou a forma prática que se relaciona diretamente ao "nível" dos alunos.

Vicente utiliza o termo "nivelar" que deixa evidente a diferença de "nível" que o professor julga haver entre os alunos. Acredito que ele esteja falando de nível como competência de acompanhamento do curso e de sua disciplina. Mas fica explícito que ele entende haver essa diferença, inclusive por ele identificar de modo direto aluno "melhor" e aluno "pior". No resumo de sua narrativa, da linha 3 à linha 5, Vicente usa os termos "adaptar", "nivelar", "nível" e "equilibrada" ("dar uma equilibrada"). Todos eles indicam diferenciação entre os alunos e, em se tratando de uma conversa que girou em torno da minha pergunta sobre modificação curricular da disciplina após a entrada de alunos "cotistas", entendo as posições em que o docente coloca o aluno "cotista" e o aluno "não cotista".

Como ele delimita o melhor aluno e o pior aluno, ao "cotista" resta o pior aluno e aos restantes os melhores alunos. Como marca dessas definições, Vicente utiliza o modal deôntico normativo "tem que", três vezes nesse mesmo 
ponto da narrativa ("a gente tem que adaptar" L3; "você tem que nivelar" L3; você tem que pegar e dar uma equilibrada L5). Este item indica a compulsoriedade que a situação das cotas traz para os docentes e para os alunos.

Quando Vicente entra na ação complicadora de sua narrativa, ele novamente indica a diferença ao identificar os alunos como "avançados", adicionando a informação de que esses alunos já haviam feito um curso específico, o que traz validade ao que está dizendo. Do mesmo modo, ele identifica como "atrasados" os demais alunos, item que traz a ideia de que se há alguém atrasado há alguém "em tempo". Ele segue narrando que "teve que" (item deôntico) agir de determinada forma em sua metodologia de ensino, modificando a prática do que normalmente fazia em sala de aula. $O$ item deôntico deixa explícita essa relação entre o compulsório que move algo normativo.

É possível perceber que não há resposta para a pergunta que eu realizo sobre o docente modificar a disciplina em si, mas resposta sobre a modificação de metodologia prática, que é o que se relaciona diretamente aos alunos. Dessa forma, fica evidente que o docente direciona determinada "culpa" aos alunos, inclusive quando não assume a mudança curricular, trazendo mudança somente do que faz referência a alunos. Assim, ele deixa visível que não considerou qualquer modificação de currículo e, por sua vez, ponderou modificar apenas o que ele considera como responsável pela mudança. Já que há a compulsoriedade em ter que modificar algo, que seja com os alunos, e não o que já está estabelecido em sua disciplina. E, como não é possível modificar o aluno em si, o que ocorreria com a não entrada de alunos "cotistas", que sejam modificadas as práticas para que o aluno se "nivele" e chegue ao nível dos demais alunos, deixando de ser o "pior" aluno.

\subsection{1.}

\section{Conclusões da seção}

A relação entre antes, agora e futuro, mesmo que travestidas de ideias positivas, constituem terreno para a formação e sustentação de estigmas sobre cotas e dão caminho para a desmoralização da própria política de cotas. Quando os professores contam as histórias sobre as transformações que as cotas trouxeram, mesmo sendo elas ao final positivas, é reforçada a ideia de que a política fez com que os docentes saíssem de seu status quo, trazendo mais 
trabalho, mais exaustão, mais medos, mais angústias, mais decepções e mais frustrações.

Em um sistema educacional brasileiro no qual o professor é tão sofrido pela falta de recursos materiais, financeiros, pessoais e psicológicos, trazer mais "problemas" a sua rotina escolar é iniciar um processo de "demonificação" da política de cotas. Quando as histórias são contadas com esse viés, por tantas situações difíceis de se lidar e de locais terríveis onde o docente é colocado, a causa dessas tristezas todas começa a ser colocada em xeque.

Sendo a política de cotas a grande causadora dessa necessidade compulsória de modificação e de mergulho em tristezas contadas pelos docentes, é como se estivessem auxiliando a construir em sociedade um sistema de coerência de senso comum de que a política de cotas só veio para atrapalhar ainda mais a vida dos professores. Para melhor ilustrar os resultados desta seção, apresento o Esquema 8:

Esquema 8: Relação entre os estigmas, narrativas e modos de realização discursiva.

REALIZAÇÃO DISCURSIVA:

- construção do

pessimismo

- questionamentos

sugestivos

- modais deônticos

normativos

- ênfase nas

diferenças entre

antes, agora e futuro

- histórico de

experiência do

professor

\section{como?}

- "o problema que

afeta o professor é

porque nosso

professor ele se

acostumou com o

aluno nota dez"

- "a gente tem que

adantar né"

Fonte: Elaborado pela autora (2020). 


\section{7. Conclusões do capítulo}

Pudemos perceber que são criados diversos estigmas para os alunos que acessam o CEFET/RJ pela política de cotas e que esses estigmas são construídos nos discursos dos docentes com os mesmos movimentos retóricos que acabam por desmantelar a política. Os padrões de estratégias indicados por Wodak et al. (2009) ajudam a apontar quais as noções macrossociais do sistema de coerência (LINDE, 1993) de senso comum estão sustentando estes estigmas.

O principal achado desse entrecruzamento de teorias é a percepção sobre o emergente desmantelamento da política de cotas e como isto fica visível com a localização dos itens de avaliação, modalização e julgamento que sustentam os temas argumentativos (WODAK et al., 2009) utilizados em cada estratégia discursiva. Nesta tese, os principais estigmas detectados que são criados para os alunos foram: o próprio termo "cotista", como separação e identificação dos alunos; o entendimento de que este local não é dele e que, por isso, o caminho a percorrer é quase impossível de caminhar e transpor "barreiras"; a idealização de que não estão no CEFET/RJ por mérito ou por opção; a construção da tragédia anunciada da evasão ou jubilamento; a metáfora de que são seres inferiores que precisam de um herói salvador; a construção de identidade fragilizada e fraca, frente à grande escola que agora estudam; a vitimização sobre as discriminações vividas dentro da escola; a mitificação do quanto atrapalham o andamento da "normalidade" da escola; a construção do imaginário sobre bases familiares completamente desestruturadas; a concepção da identidade fora de padrões de interação social; o imaginário da deficiência do aluno.

Discursivamente, os itens lexicogramaticais indicaram a grande frequência de modalização que variaram de valores baixo a alto, o que relaciono ao grau de comprometimento (HALLIDAY, 1985) dos docentes em relação ao tópico principal que cercava cada modal. Os tópicos cujo Discurso estão mais sedimentados na comunidade escolar e constituem estigmas mais evidentes são acompanhados de itens de modalização de valor mais alto. Já os tópicos de descrições de estigma sobre alunos de forma mais individualizada foram cercados de itens modais de valor mais baixo, indicando um nível menor de comprometimento.

A construção do pessimismo soa como uma previsão de que nada do que o aluno possa fazer e nenhum esforço que a instituição faça para sua permanência será suficiente para que ele permaneça na escola. Pelo julgamento de essas 
dificuldades serem tão enormes, e os alunos "cotistas" serem tão fracos, eles não conseguem passar de ano e optam, sozinhos, por sair da escola ou, caso tentem pela segunda vez, são jubilados. A transferência de responsabilidade se explicita aí, quando diversos termos utilizados para narrar as histórias são direcionados ao aluno como o decisor do ato de sair da escola por "perceber sua incapacidade", e não à escola como responsável por esta saída.

Sendo a responsabilidade de permanência atribuída ao aluno, o que se conjuga com o sistema de coerência da meritocracia entendo, então, que este local não é para ele. Segundo as narrativas desta pesquisa, o CEFET/RJ é uma escola para alunos que possam transpor as barreiras que se impõem pelo caminho. Dessa forma, não há autoria sobre quem colocou os obstáculos neste caminho e ultrapassá-los pode ser possível apenas para alunos de não cota, e é quase impossível para os alunos de cota. Para percorrer essa trajetória tão árdua e intransponível, fazem-se necessários os heróis, seres superiores que podem fazer o favor de ajudar os alunos "cotistas". O cenário criado nas histórias é aquele em que determinado aluno foi salvo pela ação do docente ou de outro aluno "não cotista".

Nesse sentido, os alunos "cotistas" têm identidade construída pelo estigma de fragilidade e fraqueza frente à escola que não é espaço deles, porém, já que habitam ali, são um elemento fraco emocional e academicamente. E, por esse motivo, precisam necessariamente de um elemento de salvação que, nas narrativas dos docentes entrevistados, é sempre um elemento de maior poder. A assimetria é estabelecida nas histórias e não somente atribuída aos docentes ou alunos "não cotistas", mas também à própria instituição como uma espécie de personificação. É preciso que esses elementos de poder ajam sobre os "cotistas" para que, agora sim, eles sejam salvos e tenham "alguma chance" fora do mundo que eles vivem em seu meio de criação e vivência social

O contraditório das narrativas é que, ao mesmo tempo em que os alunos são construídos como fragilizados por tantas coisas ruins que os cercam e por tantas características que os inferiorizam, os próprios docentes entrevistados não parecem lidar bem com a mesma fragilidade. Tratam como vitimização, definindo as discriminações ou racismos como casos raros e pontuais que não ocorrem na instituição com frequência. Do mesmo modo, lidam com as dificuldades de aprendizagem descritas por eles mesmos como não aproveitamento da chance que é dada aos alunos. Os alunos têm dificuldade de aprender, mas não se empenham o suficiente para isso. 
O paradoxo se dá nessa relação entre o que os docentes dizem e o que eles realizam em seus discursos. Ou seja, há a construção da fragilidade dos alunos "cotistas" e o que eles fazem com essa fragilidade é culpabilizar os alunos por elas. Isso acaba por enfraquecer a política de cotas e, por isso, entendo como uma estratégia retórica de descrédito da legitimidade que as cotas possam ter. Quando isso ocorre, evidenciam-se elementos discursivos de alinhamento ao sistema de coerência da meritocracia. Ao mesmo tempo em que são utilizados argumentos que definem e caracterizam o "cotista" como fraco e coitado, esses mesmos elementos atualizam discursivamente o ideal da meritocracia, já que os alunos deveriam lutar para passar por cima das dificuldades e, pelas histórias dos docentes da minha pesquisa, não o fazem.

$E$, por não realizarem todo o trabalho que os docentes entendem que os alunos "cotistas" deveriam fazer, há a concepção do abalo da normalidade estabelecida no CEFET/RJ. Partindo do pressuposto de que a instituição personificada tem o poder maior, especialmente sobre os alunos, todo e qualquer elemento que surja para desestruturar o estabelecido é visto como perturbador da ordem. Nas narrativas dos docentes entrevistados, há uma nuvem mítica sobre o quanto os "cotistas" atrapalham tudo que havia antes de 2013 na escola. Modificam as atividades escolares rotineiras, modificam o trabalho das equipes pedagógicas, trazendo mais problemas, oneram o andamento das aulas, trazendo atrasos de aprendizagem e conteúdo aos demais alunos, e mais trabalho aos docentes, que precisam realizar tarefas mais direcionadas aos "cotistas".

E nessa estrutura são criados, discursivamente, todos os estigmas sobre os alunos, tendo em conta que são vistos como elementos desestruturadores. E sendo os "cotistas" o ponto fora da conformidade do sistema estabelecido, entra a idealização de que eles estão no CEFET/RJ por favor e, por isso, têm que aproveitar a oportunidade que lhes foi dada. Nas narrativas, os alunos não estão nessa escola por mérito, é como se não tivessem tido opção ou escolha em entrar na escola. Há uma espécie de ocultamento ou esquecimento de que houve o concurso público realizado por eles e por todos os alunos matriculados no CEFET/RJ. O certame pelo qual passaram é completamente preterido nas histórias, quando são construídos os ideários da falta de mérito por ocuparem a vaga pública.

Para melhor ilustrar a ideia do que discuto aqui, a seguir seguem dois esquemas sobre todas essas construções dos discursos. No primeiro, mostro a relação cíclica de construção dos principais estigmas encontrados nas narrativas dos docentes entrevistados para esta pesquisa. Os estigmas se "retroalimentam" 
em uma relação em que, além de serem construídos através das narrativas, é também por meio dessas narrativas que eles são reforçados e perpetuados.

Esquema 9: Ciclo dos principais estigmas.

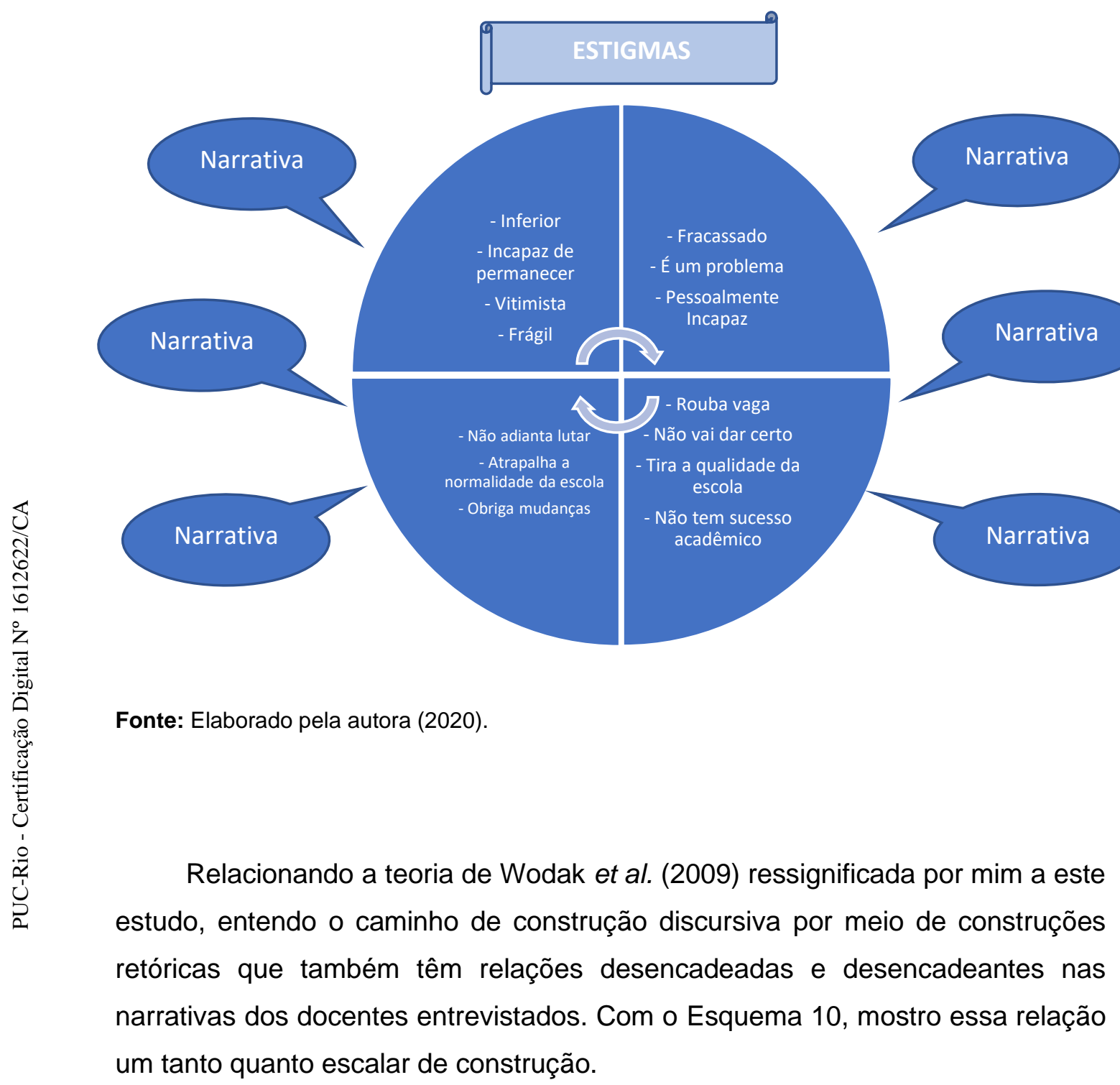


Esquema 10: Organização da construção discursiva de índices sobre o "cotista".
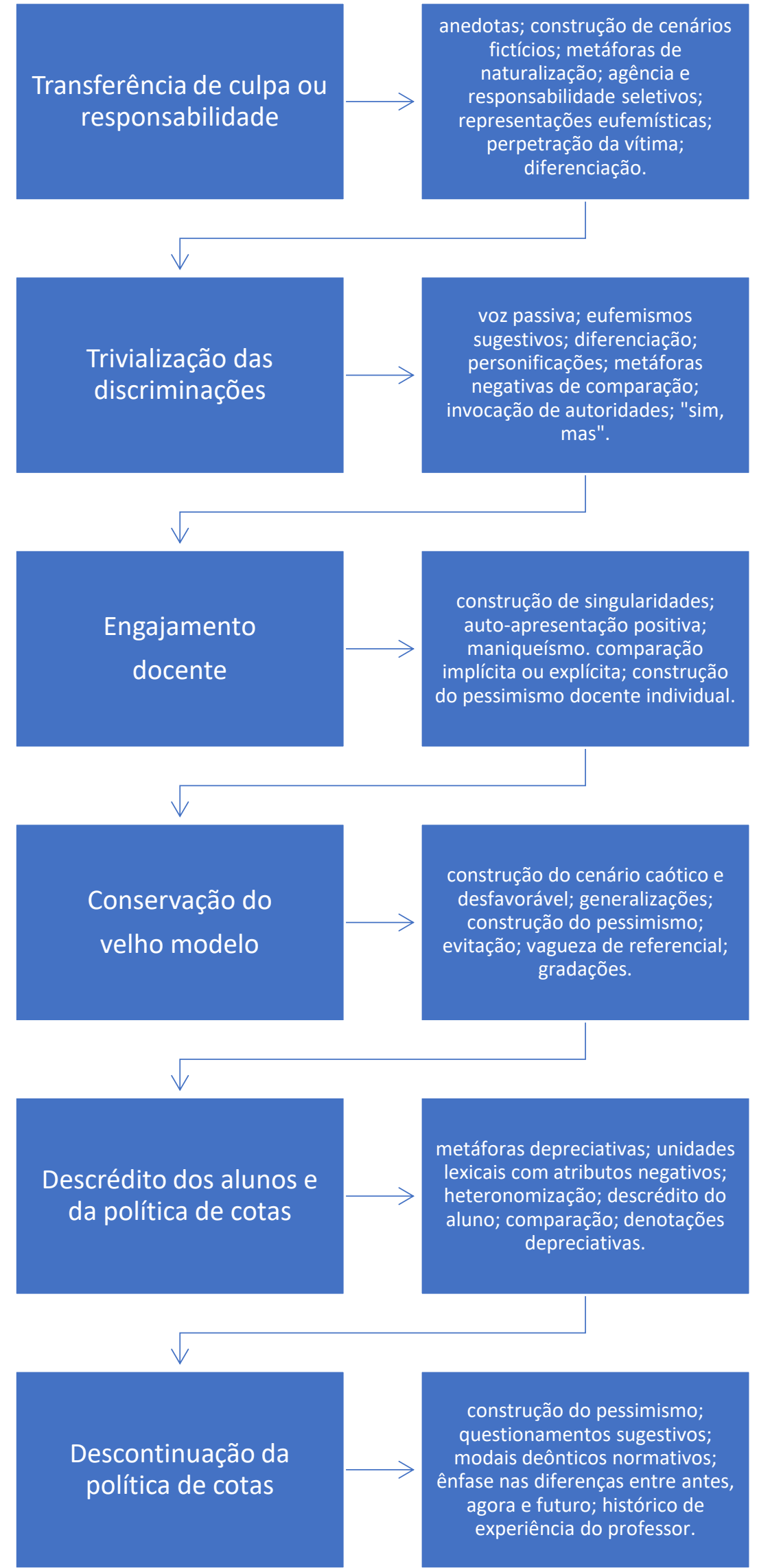

Fonte: Elaborado pela autora (2020). 
Com esse desenho, explico, de forma esquematizada, a relação de construções discursivas que acontecem nas narrativas dos docentes entrevistados nesta pesquisa. Desse modo, podemos, por fim, entender o caminho que encontrei nas histórias contadas que vão criando, transformando, ratificando e atualizando os sistemas de coerência de meritocracia sobre cotas e, por consequência, os estigmas. No próximo capítulo, discuto as conclusões finais a partir dos resultados das análises realizadas nos 43 excertos em que expus e investiguei as narrativas dos docentes, de modo a finalizar todas as reflexões que propus para esta tese. 


\section{6 \\ Considerações Finais}

"Eu não imaginava, eu não imaginava... porque no meu antigo colégio eu mantinha notas muito boas nove, dez, quando tirava um sete era um desespero, né... e aí, quando a gente, eu cheguei aqui no primeiro ano minhas notas foram horríveis, sabe eu tirei nota três em algumas matérias, então, pra mim foi horrível, não tem outra palavra, porque eu não imaginava que eu poderia cair tanto assim, então, a gente com começa a se sentir, assim, incapaz, né, a gente pensa, fala assim 'caraca, a gente não é tão boa quanto a gente imagina, né' então, eu não imaginava que eu que aqui teria um nível tão alto quanto a gente tem mas, é...foi bem forte pra mim e nenhum momento eu pensei que seria desse nível, desse jeito"

(Trecho da entrevista realizada com Suzana aluna participante desta pesquisa.)

Convido o leitor desta tese para refletirmos juntos sobre os resultados até aqui obtidos. Como dito no capítulo 4, quando realizo a exposição das teorias que minha pesquisa abraça, as narrativas são o objeto fundamental sobre o qual me debruço para construir entendimentos sobre cotas. Em nossa vida, estamos o tempo todo narrando histórias, situações, casos, etc. e, em minha concepção, esse é o melhor terreno para encontrar as respostas para o que tanto me afligiu quando ouvi, no início de tudo, em um conselho de classe, uma professora dizer que os "cotistas" iriam acabar com a qualidade da escola. Não à toa essa frase dá título a esta tese. Nos últimos dias de escrita desta tese, ao entrar por uma das portarias do CEFET/RJ para iniciar mais um dia de trabalho, deparei-me com o seguinte cartaz:

Figura 2: Cartaz exposto em um dos acessos principais do CEFET/RJ.

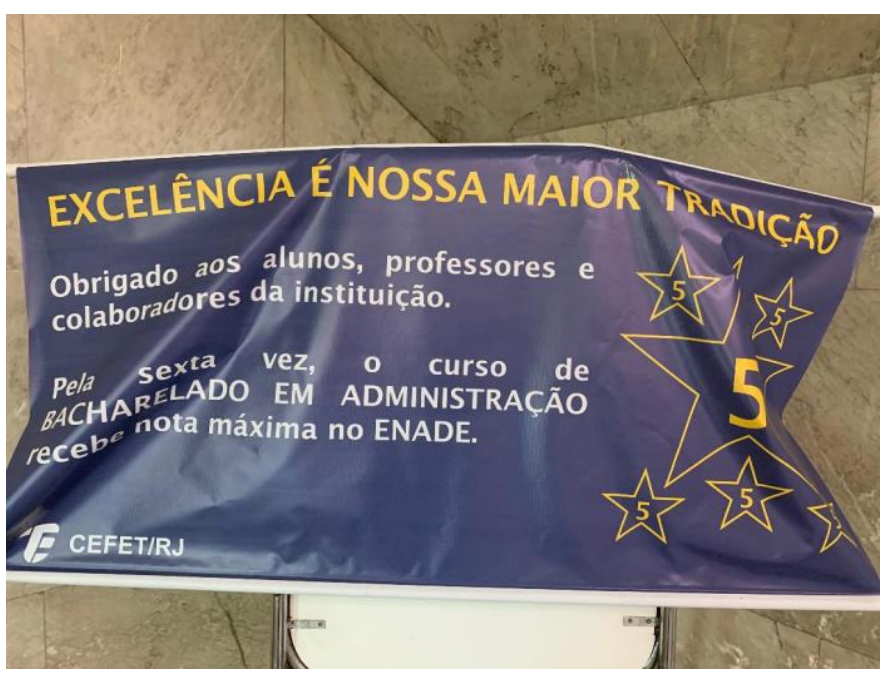

Fonte: Foto tirada pela autora em fevereiro de 2020. 
Esse cartaz é exibido em uma das portarias principais da instituição, ou seja, qualquer pessoa que adentra a escola recebe, sem escolha, uma boa pista sobre a identidade institucional da escola. Parece não haver possibilidade de que o CEFET/RJ seja algo diferente de "excelente" e, pela frase, esta é, dentre todas, a sua "maior tradição". No início e ao fim desta trajetória de pesquisa, "tradição" e "qualidade" são signos tornados relevantes para se descrever o CEFET/RJ.

É de fato possível pensar em diversas tradições que naturalmente foram construídas, sedimentadas, ao longo do centenário da instituição e ressignificadas de acordo com os contextos sociais e políticos. A "excelência" da escola foi construída ao longo do tempo com as mudanças de alunado e com as tendências mercadológicas ou industriais que guiaram, e ainda guiam, o tipo de formação que se quer oferecer e dar aos alunos. No imaginário coletivo, obviamente cercado por um determinado sistema de coerência específico, a "qualidade" e a "excelência" parecem estar ligadas diretamente a um alunado diferente do que a política de cotas tem levado à escola nos dias de hoje. Com o aluno "cotista", as tradições, construídas ao longo dos cem anos, são desestabilizadas.

E esse sistema de coerência específico do qual falo aqui é o grande achado desta tese: a meritocracia. A partir desse discurso, entendemos como a política de acesso ao CEFET/RJ está discursivamente ligada à manutenção da qualidade. As modificações que a política de cotas impôs ao concurso de acesso ao CEFET/RJ abala uma tradição, trazendo à tona os discursos, identidades e expectativas atribuídas aos "cotistas". Esta pesquisa de doutorado se dedica a investigar esses elementos e o modo como eles comparecem nas narrativas dos docentes.

Para fins de organização deste capítulo de considerações - que não considero finais -, retomo a seguir os objetivos de pesquisa que propus na introdução da tese.

\section{A partir de que recursos lexicogramaticais e discursivos as narrativas docentes constroem e negociam o estigma das cotas?}

Para o primeiro objetivo que propus para este estudo, busquei as marcas de avaliação presentes nas narrativas dos docentes. Nesse momento, identifiquei, então, os itens lexicogramaticais e paralinguísticos de avaliação nas descrições sobre os alunos "cotistas". A pioneira e grande questão que se impôs foi compreender o termo "cotista", rótulo dado aos alunos que acessam o CEFET/RJ pela política de cotas e tomado por toda a comunidade escolar como identificação 
desses alunos. Dou tamanha importância ao termo por ele ser, por si só, um índice do discurso sobre as cotas e sobre os alunos. A partir dele se dão todas as caracterizações que separam, desde o próprio termo, os alunos "tradicionais", vindos da ampla concorrência, e os alunos "novos", oriundos das cotas.

Se o adjetivo "cotista" é um índice, passei a tentar entender para quê, exatamente, a insistência nessa categorização aponta. Em termos de discurso mais macro, o termo tem um caráter segregacionista. Embora esse seja um técnico, relevante apenas durante o concurso para acesso à escola, o adjetivo é tornado relevante por toda a instituição e ao longo de toda a vida acadêmica dos alunos. Por isso, entendi esse rótulo como principal índice de estigma: o "cotista" nunca deixa de ser "cotista", desde o início do processo seletivo até a sua formatura.

No primeiro momento, os itens de avaliação foram os elementos que se destacaram nas narrativas dos docentes e, por isso, os elenquei como itens que me trariam respostas aos questionamentos sobre as construções discursivas dos estigmas. As metáforas apareceram de diversas formas e com funções um pouco diferenciadas, dependendo da estratégia ${ }^{46}$ discursiva utilizada pelo professor que narra. Neste estudo, percebi duas formas diferentes de construções metafóricas. Em uma forma, as metáforas aparecem em anedotas contadas pelos professores, naturalizando para o "cotista" comportamentos exagerados, como visto na narrativa de Ana (excerto 6), em que ela conta que o aluno fez a ponta do lápis com a unha e o dente. De outro modo, as metáforas surgem para construir descrições ou ações depreciativas dos alunos, como "ficam quatro anos batendo cabeça aqui" e "tiram a vaga de alguém" (ambas de Paloma, excerto 30). Essas metáforas colaboram para compreensão do aluno "cotista" como intruso e indesejável à instituição, criam os estigmas que inferiorizam esses alunos, atribuindo a eles expectativas de comportamentos estereotipados e situações familiares estereotipadas, bem como a falta de formação social básica de relacionamento interpessoal. Do mesmo modo, as metáforas também posicionam ideologicamente o lugar dos alunos sobre as vagas e no espaço público federal. Isso traz avaliações de sanção social sobre os alunos manifestando o Julgamento, questionando eticamente condutas e comportamentos dos alunos.

Encontrei, também, estratégias de seleção de agência e responsabilidade. A agência seletiva se dá em formações do tipo "ser expulso da escola" (excerto 33), que não apresenta agente, mas que atribui a evasão dos alunos a eles

\footnotetext{
${ }^{46}$ As estratégias serão perfeitamente discutidas na revisão do 3o objetivo, mais à frente.
} 
mesmos. Há também transferência da responsabilidade quando os docentes utilizam itens como "minha opinião". Nesse ponto, há o desvio na responsabilidade institucional para "apenas", uma opinião particularizada que pode ou não remontar uma ação (ou não ação) do CEFET/RJ como um todo. A falta de agência e responsabilidade é, por si só, uma forma de avaliação implícita sobre o que se pensa sobre os alunos "cotistas".

Outra característica discursiva, a recorrência de representações eufemísticas, trouxe itens de avaliação como "fraquinho" (narrativa não analisada), "fraco" (excertos 4, 11, 36), "dificuldade de abstração" (excerto 13), "menos preparados" (excerto 21), "uma categoria mais fraca" (narrativa não analisada), etc. que são sugestivos. Essas avaliações indiciam uma expectativa de inferioridade para os alunos "cotistas", pressupondo dificuldades por vezes exageradas e vistas como incorrigíveis. Daí, vieram mais itens, então, de avaliação que representaram um pessimismo esperado e atribuído à escola após a implantação da política de cotas. Um exemplo recorrente nas narrativas são os itens "susto" (excerto 6 e excerto 32) e "pânico" (excerto 5) que remontam, também, a uma diferenciação cronológica, qualificando os tempos de antes e após as cotas.

Os itens de avaliação que reputam inferioridade aos alunos questionam a capacidade de permanência e prosseguimento deles no caminho acadêmico dentro do CEFET/RJ, trazendo a dimensão do julgamento de estima social. E, com a transferência de responsabilidade sobre o insucesso dessa trajetória acadêmica, surgem as vozes passivas e as personificações. As vozes passivas aparecem exatamente para apagar a ação de sujeitos, também chaves, nesse processo: os docentes, as equipes pedagógicas e as pessoas que atuam diretamente nos processos educacionais didáticos e/ou de permanência dos alunos na escola. Para que esse mecanismo discursivo aconteça, também surgem as personificações, que transferem a culpa a elementos como "cota" e "escola" (a cota traz algo, a escola expulsa, etc.).

Encontrei gradações em diversas narrativas e entendo que essas construções tenham dado força dramática às histórias contadas. Os itens de avaliação de alta gradação, como "primeira qualidade", "enxurrada" (ambos no excerto 2), "gritando o tempo todo" (excerto 3), "bem, bem bicho do mato (excerto 10), etc., são intensificadores que constroem a gravidade da dificuldade sobre as cotas projetada nas histórias. Foram incontáveis os usos de itens de alta gradação pelos quais detectei o objetivo de intensificar as histórias que estavam sendo narradas sobre as cotas. 
Por fim, há ainda recursos como as evitações e hesitações, que se complementam com os numerosos itens modais por meio dos quais indiquei o grau de comprometimento dos docentes em suas narrativas. Com os itens modais, foi construída uma vagueza de referencial nas histórias narradas pelos professores. Os modais deônticos normativos serviram para enfatizar, na fala dos docentes, a diferenciação cronológica nos momentos de valoração entre o "antes" e "depois" das cotas, evidenciando características de compulsoriedade de aceitação da política de cotas e obrigatoriedade de mudanças de suas metodologias.

O segundo objetivo traçado por mim se debruçou sobre uma camada mais "macro" discursiva do discurso dos docentes, conforme abaixo.

\section{A quais sistemas de coerência os docentes se afiliam? Quais são as marcas de alinhamento dos participantes com discursos (re)produzidos e ancorados em sistemas de coerência de senso comum sobre cotas?}

Essa questão surgiu para entender os sistemas de coerência aos quais os docentes participantes se alinham na construção de suas narrativas. O principal achado desta tese, nesse sentido, foi o alinhamento dos discursos ao sistema de coerência da meritocracia. Michael Young desenvolve essa ideia no livro The Rise of the Meritocracy (1958), e é citado por Jo Littler por conta de, nessa obra, a meritocracia "ser apresentada como uma ideologia ou princípio organizativo que se tornará um problema, nos guiando a novas inequalidades de poder e formas de estratificação social" (LITTLE, 2018, p. 35).

Percebi, através das narrativas dos professores, que as novas estruturas de poder são mantenedoras das antigas existentes no CEFET/RJ. Quando encontrei, nas narrativas, exemplos de construções discursivas que distribuem e ratificam os locais em que se encontram os "cotistas" e os "não cotistas", por exemplo, na distribuição das vagas federais, entendi que a ideologia da meritocracia, também conforme Jo Littler (2018), está guiando as estruturas da sociedade para novas posições de estratificação social. A própria separação simbólica, e porque não, ideológica, do termo "cotista" discutido no início destas considerações já marca a distribuição desses locais.

Por isso, a metáfora da escada, que apareceu em diversas narrativas dos docentes que entrevistei, foi considerada e analisada no capítulo 5, após ter sido discutida no capítulo 4. Essa metáfora aponta para a ideia, problemática, em minha opinião, de que a ascensão é individual, dependente e aptidões vocacionais 
pessoais, e isolada de fatores interseccionais que atravessam os alunos, ou do conjunto de oportunidades que o sujeito tem para seu sucesso.

Então, exemplos de construções discursivas, como a gradação "ele evoluiu, ele cresceu, ele hoje sabe se comportar, ler, etc". (excerto 40), marcam o alinhamento dos docentes, nesta pesquisa, com o sistema de coerência da meritocracia. Esse sistema de coerência monta e sustenta as assimetrias entre os alunos "cotistas" e os demais partícipes da escola, ratificando formas de segmentação social. Além disso, reforça a questão já discutida aqui sobre a quem pertence o lugar e, por consequência, a vaga pública federal.

Os elementos discursivos encontrados nas narrativas dos docentes desta pesquisa apontaram para a culpabilização do próprio aluno "cotista" sobre sua desistência, incapacidade e evasão. É aí que se entrevê o sistema de coerência de senso comum da meritocracia; no capítulo de análise, eu aponto os recursos discursivos que indexicalizam a transferência de responsabilidade sobre a permanência na escola ao aluno, isolando, como já se disse, quaisquer variáveis externas que incidam sobre seu processo educacional. E sendo o CEFET/RJ uma escola historicamente construída para os "fortes", que prima pela "tradição da qualidade", como diz seu cartaz da entrada, entendo que há, então, obstáculos postos e colocados para serem de difícil transposição.

Uma marca que aparece nos dados é a falta de agência sobre quem criou ou cria as dificuldades de permanência dos alunos. Os professores se apagam, discursivamente, como responsáveis dessas dificuldades, desresponsabilizando a instituição sobre o insucesso do aluno. Na contramão, observa-se a responsabilização direta do aluno sobre seu fracasso e sua evasão. A esse respeito, as narrativas de ascensão ao topo por esforço individual, conforme descritas por Littler (2018), estão a serviço de popularizar o sistema neoliberal que organiza o mundo a partir de interesse de poucos. Assim também são as vagas públicas do CEFET/RJ que, sob essa ótica, são simbólica e historicamente pertencentes a uma minoria, o que é reforçado por meio das histórias contadas.

Caminhando para finalizar as conclusões em torno dos objetivos propostos, relembro o terceiro objetivo desta tese:

3. Quais estratégias retóricas os docentes utilizam para criação, manipulação, manutenção, resistência, subversão, etc. dos sistemas de coerência sobre cotas vigentes na sociedade? 
Nesta tese, também analisei os dados de modo a tentar entender que estratégias retóricas são mobilizadas nas estratégias dos docentes e colaboram para a construção dos estigmas dos alunos. Nesse ponto, foi necessário adentrar as teorias da Análise Crítica do Discurso, articulando essa área com as outras teorias propostas nesta tese. Para tal, como pode ser visto no capítulo 5 de análise, dividi as narrativas em seis categorias, de acordo, primariamente, com as ideias de estratégias retóricas proposto por Wodak et al. (2009), e adaptadas por mim para esta pesquisa.

A primeira estratégia elencada por mim foi a de Transferência de culpa ou responsabilidade. Através da análise das narrativas, foi possível encontrar ocorrências discursivas de heteronomização, de apontamento de um bode expiatório, de perpetração da vítima, de inversão, de exclusão social, de metáforas de naturalização, de agência e responsabilidade seletivas e de representações eufemísticas.

Em seguida, foram analisadas as narrativas de Trivialização das Discriminações, que ocorrem por semelhança negativa. Estratégias do tipo "sim, mas", topos de "grupo pequeno" e "caso isolado", eliminação do agente, voz passiva e eufemismos, apelo/invocação à/de autoridade, minimização das problemáticas, diferenciação entre alunos e metáforas de comparação.

Seguindo as narrativas de Engajamento docente, foi possível perceber a ocorrência dessas construções discursivas através de autoapresentação positiva, maniqueísmo, construção da singularidade, preocupação de sentimentos compartilhados, unificação de forças contra a perda de autonomia e unicidade. Após o engajamento, encontrei, então, as estratégias de Conservação do velho modelo, sendo construídas discursivamente através de idealização do desastre e do sofrimento, pessimismo, evitação, vagueza de referencial, gradações, generalizações e negação da necessidade de mudança política.

Seguindo a ordenação que propus para a tese, analisei as estratégias de Descrédito dos alunos e da política de cotas, que evidenciaram a sua ocorrência discursiva através de apresentação negativa do aluno, metáforas depreciativas, estratégia de pessimismo, unidades lexicais com atributos negativos e, novamente, a heteronomização. E, por fim, detectamos as narrativas de Descontinuação da política de cotas, ocorridas por itens que apontaram para a difamação, mais uma vez ao pessimismo, a topos de desastre, à descontinuação, a topos comparação entre antes e, agora, a modais deônticos normativos e a questionamentos sugestivos. 
Em resumo, a análise das narrativas caminhou para o entendimento de que há ideologias (discursos) que percorrem o ideal de deslegitimação da política brasileira de cotas e no CEFET/RJ. Dessa forma, índices sobre cotas e sobre os "cotistas" apontam para estigmas. Tais estigmas são manipulados e mantidos enquanto interpretações quase que institucionalizadas sobre os alunos.

Muitos estigmas foram criados nos fóruns de discussão virtual e em reuniões presenciais, e esses estigmas comparecem e são reforçados em cada história contada para esta tese. Dessa forma, há a cristalização de certa visão sobre o "cotista", que deslegitima a política de cotas brasileira. Ao final, é mais sobre como é preciso comprovar que os índices criados estão certos do que atentar ou enxergar como de fato o aluno "cotista" está caminhando dentro da escola.

\section{1.}

\section{Aplicações e implicações}

Um dos maiores desafios que enfrentei na escrita desta tese foi o confronto com as minhas diferentes posições no contexto de pesquisa, com a minha atuação profissional e atuação enquanto pesquisadora. Tudo que pesquisei veio do terreno onde trabalho e atuo profissionalmente todos os dias, e as narrativas das entrevistas vieram de colegas de trabalho com quem atuo rotineiramente. O tema, além de controverso, é de interesse da comunidade escolar, incluindo os participantes da pesquisa. Sendo assim, é um dilema pessoal entender a forma como devo retornar esses resultados a todos.

Como já disse em diversos pontos deste texto, os discursos são tão bem sedimentados que, por vezes, freiam as ações críticas que possam surgir, especialmente, como resultado de pesquisas fundamentadas teoricamente como esta tese. Mas, ainda assim, entendendo a importância de retornar à instituição e a sua comunidade os resultados aqui obtidos, não apenas a publicização da tese será suficiente para os fins a que me propus quando resolvi iniciar meu doutoramento. Será necessária pelo menos uma apresentação formal dos dados, discussões e resultados de tese para que seja atingido meu objetivo principal, de gerar reflexões sobre o que propagamos ao contar histórias.

É preciso entender que narrar não é um ato simples de passar à frente uma história que aconteceu ou se viu acontecer. Narrar é dividir - e construir - com outras pessoas, ideologias, valores, concepções, sentimentos, emoções, etc. E, 
partindo dessa ideia, cabe a reflexão sobre a repercussão das histórias sobre cotas, conforme se viu aqui, para os "cotistas".

Que significados os alunos constroem sobre si, sobre seus colegas, sobre a instituição que deveria os acolher ao longo de sua formação? Além disso, em que lugar o aluno "cotista" passa a se colocar quando é apresentado a ele um espaço que, pelos sistemas de coerência da meritocracia, não lhes pertencia desde o princípio? Como esse aluno percorre sua trajetória acadêmica nesse espaço? É importante relacionar os posicionamentos sobre cotas não só aos sistemas de coerência de senso comum estabelecidos dentro da instituição, mas com o Discurso (re)produzido e atualizado com essas narrativas (re)contadas nos ambientes institucionais.

E, o viés autoetnográfico que propus na tese me proporcionou entender minha posição e lugar nessas construções de estigmas e sentidos sobre cotas e alunos. Essa pesquisa me tocou, particularmente, não só por fazer parte deste contexto, mas por coconstruir os sistemas de coerência apresentados nas análises. Após perceber os alinhamentos, as construções compartilhadas nas interações gravadas, a reprodução de discursos de senso comum, o uso deliberado do termo "cotista", como identificação dos alunos, etc. pude me refletir ao longo da pesquisa. Foi importante me perceber e me reelaborar enquanto membro dessa comunidade da qual faço parte e ajudo a manter esse sistema que eu mesma questiono nesta tese.

Por esse tipo de reflexão, os resultados desta pesquisa devem ser levados de volta à instituição, independente dos desconfortos que existirão nesse momento. Desde o início da pesquisa, eu me debrucei sobre o caráter autoetnográfico deste estudo. Do mesmo modo, também desenvolvi as questões éticas que esta pesquisa impõe, e o contato da comunidade institucional com os resultados aqui obtidos também faz parte disso. Acima de qualquer incômodo, coloco em foco, nesse momento, a importância dessas discussões gerarem as reflexões que espero que sejam geradas.

Essa importância se estende à comunidade brasileira como um todo, já que a política de cotas se aplica às instituições públicas, sejam de ensino superior sejam de ensino básico, como o CEFET/RJ. Vale um lembrete do que disse na introdução desta tese quanto à escassez de estudos sobre cotas que abarquem questões subjetivas e em especial sobre os alunos. É possível encontrar pesquisas mais quantitativas que realizam levantamentos estatísticos ou pouca análise qualitativa sobre, em geral, o desempenho acadêmico dos alunos "cotistas". Por isso, considero que minha pesquisa traga contribuições para que 
as políticas afirmativas educacionais sejam repensadas por outro viés, mais humanitário e que entenda com maior profundidade as (auto)construções sobre os alunos e suas consequências.

No campo da educação, é interessante que esses resultados tragam a possibilidade de se ponderar sobre o que é dito sobre cotas nos ambientes escolares. Do mesmo modo, espero que o cuidado com o discurso sobre cotas se torne elemento a ser considerado nas discussões pedagógicas nas instituições nas diversas frentes existentes, incluindo os currículos. Para as áreas sociológicas, almejo que as discussões aqui realizadas junto às análises se tornem passo ou passagem para uma reflexão sobre as políticas públicas afirmativas como um todo no Brasil. Pensar a construção dos estigmas a partir do discurso amplia entendimentos sobre a sociedade brasileira em si, a mesma que escreve as leis sobre as políticas afirmativas.

Para o campo da Linguística Aplicada, tenho a expectativa de que os pesquisadores da área abram os olhos para o rico caminho que a junção de teorias e metodologias de análise do discurso pode oportunizar. Abrir o caminho para a conjunção de diferentes linhas de análise diminui o distanciamento das áreas e minimiza a oposição/concorrência entre diferentes teorias de discurso. Essas podem não se anular e percorrer um caminho mais de completude do que de exclusão entre si. Considerando o caso desta tese, a pesquisa necessitou de metodologias e análise diferentes para que tomasse o sentido crítico que precisava ser capturado nas análises, diante de um tema tão importante socialmente para o Brasil.

Por fim, consigo compreender que as narrativas analisadas trouxeram sistemas de coerência da meritocracia que estão percorrendo a sociedade brasileira como um todo. Por isso, o que é replicado nas histórias contadas em minha pesquisa são reproduções de ideologias sobre cotas que estão no imaginário da população dentro e fora do CEFET/RJ. Por esse motivo, tudo que neste estudo foi descoberto é extensível a concepções sobre cotas por todas as instituições do Brasil que aplicam a política. Os estigmas criados no CEFET/RJ podem não ser os mesmos estigmas criados para os alunos "cotistas" de universidades, por exemplo, mas a base ideológica contida nas estratégias utilizadas é de nível macrossocial e pode e deve ser considerada em estudos futuros para estigmas sobre cotas. 


\section{2. Limitações}

Infelizmente esta pesquisa teve limitações e as duas principais a serem consideradas aqui foram a falta de aprofundamento nas questões étnico-raciais e a consideração também da voz dos alunos "cotistas" nas narrativas. Para a primeira questão, cabe explicar que adentrar as políticas de cotas pelo viés racial traria a possibilidade de escrever outra tese, a ser desenvolvida em outra pesquisa. As narrativas engendradas pela fase de geração de dados continham pouco material sobre raça em si, porque, nesse contexto de pesquisa, especificamente, a parcela de alunos que acessam o CEFET/RJ pelo grupo racial é pequena, conforme já explicado no início da tese como se dá a distribuição dos grupos de cotas.

Acredito que o caminho que as narrativas tomaram também foi fruto das perguntas que fiz aos docentes no momento das entrevistas. Em apenas uma pergunta eu relacionei diretamente as cotas à questão racial: quando perguntei se os docentes haviam presenciado alguma situação de discriminação ou racismo no CEFET/RJ. O que detectei a partir dessa pergunta foi o apagamento ou silenciamento do racismo nessa instituição. Os casos contados eram os mesmos por terem se tornado os mais famosos em redes sociais. Não me pareceu que essas mesmas histórias estavam sendo repetidas em diversas entrevistas da pesquisa pelo conhecimento de fato do que ocorreu dentro da instituição. O que os professores tornaram relevante nas entrevistas foi origem social, e não raça. Isso não quer dizer que não haja racismo na instituição, apenas que raça não povoa o discurso institucional. O mais marcante, a esse respeito, foram os momentos em que, logo após narrar as histórias mais conhecidas sobre o racismo, os docentes negavam que as situações de discriminação eram comuns no CEFET/RJ. Por esse motivo, entendo que há um silenciamento sobre a questão racial e sobre o racismo no CEFET/RJ.

Já sobre a segunda limitação apresentada - a ausência das narrativas dos alunos -, cabe dizer que foram geradas entrevistas com os alunos "cotistas" do grupo $5^{47}$, porém, não houve tempo hábil para adentrar analiticamente essas narrativas. Em linhas gerais, os resultados que seriam obtidos dessas análises seriam direcionados para o viés analítico da interação, tendo em vista a autoprojeção positiva de si que os alunos realizaram durante as entrevistas. Teria

\footnotetext{
47 Ver explicação sobre a distribuição das cotas no CEFET/RJ.
} 
sido interessantíssimo se houvesse tempo para realizar uma comparação entre as descrições positivas que eles desenvolveram, em oposição às caracterizações negativas que os docentes apresentaram em suas narrativas.

Por curiosidade, deixo aqui em breves linhas o que ocorreu. Como explicitei nas análises que realizei no capítulo 5 , os docentes construíram índices diversos dos estigmas sobre os alunos "cotistas". Essas caracterizações traçaram um perfil de alunos não capacitados, dentre outros, e inabilitados a cursarem o CEFET/RJ. Como já se pôde verificar nas análises desta tese, os professores os descrevem quase que como analfabetos. Ocorre que, nas narrativas dos alunos "cotistas", em um dado momento da entrevista, os alunos quase que em sua totalidade contavam histórias de como eram valorizados em suas antigas escolas, por serem os melhores alunos. Contaram que eram indicados por serem melhores alunos e que obtinham médias que beiravam dez e que, por isso, foram estimulados pelas direções e coordenações de suas antigas escolas a realizarem concursos como o do CEFET/RJ.

Essas ideias serão levantadas na próxima sessão sobre os caminhos futuros que podem ser tomados a partir desta pesquisa e para os temas que são envolvidos nesta tese em si. Infelizmente, não foi possível dar atenção a esses itens e foi escolha consciente deixá-los de lado, mesmo sabendo de sua importância. Como é bem sabido no meio acadêmico, em pesquisas de doutorado é necessário, em um dado momento, realizar escolhas para o direcionamento das análises.

\section{3. \\ Caminhos Futuros}

Esta tese abre espaço para que pesquisadores interessados na temática repliquem as metodologias analíticas aqui aplicadas. O tema de cotas é de interesse de diversas áreas do conhecimento. Ao se conjugar as metodologias que conjuguei, foi possível identificar elementos do discurso que só foram percebidos por essa "harmonização" de teorias. Essa ideia traz a possibilidade de se romperem as barreiras de união entre linhas diferentes de análise do discurso para que outras formas de associação de metodologias sejam realizadas.

Ainda seguindo o caminho do que expus na seção anterior, foram gerados dados que não foram analisados com maior profundidade e expostos neste 
estudo. As narrativas dos alunos "cotistas" podem e devem ser analisadas com o fim que descrevi como limitação de pesquisa. Adicionando essas análises em perspectiva comparativa, será possível observar como os alunos "rebatem" ou descontroem os índices sobre cotas das narrativas dos docentes, subvertendo os sistemas de coerência de senso comum sobre cotas no Brasil. Ou seja, nessas narrativas dos alunos "cotistas" que gerei e não analisei com profundidade, não há somente uma autoprojeção (micro)interacional de self, mas há tentativas ativas de desconstruções de sistemas tradicionais que formam os significados sobre qualidade de ensino, sobre preconceito, sobre cotas, etc.

Há, ainda, a possibilidade de adentrar o campo da temática étnico-racial, trabalhando sobre o discurso racializado e racista que atravessa e se constitui nas falas/narrativas dos professores. Essa questão também gera uma nova pesquisa e deve ser valorizado todo o aporte teórico sobre ela. Nesse sentido, a temática central não giraria em torno de estigmas somente, mas sobre apagamentos dos tópicos raciais nas instituições de ensino. Nessa direção, será necessário buscar os sistemas de coerência que percorrem o silenciamento, ou opção pela não exposição dos casos. Ou, por outro lado, gerar a reflexão sobre quais compreensões a comunidade escolar tem sobre o que de fato é racismo para eles.

Por fim, qualquer desses caminhos para pesquisas futuras que apontei nesta seção são importantes, não somente por serem olhares diferentes dos que ofereço aos dados que gerei, mas por já terem transcorrido quatro anos desde a geração de dados. Não somente os significados criados sobre os alunos "cotistas" modificaram-se ao longo do ciclo completo de formação da primeira entrada dos alunos no CEFET/RJ: o cenário político brasileiro e, por sua vez, institucional também mudou drasticamente. Sendo assim, com as novas governanças e com as ameaças às políticas afirmativas em geral, é de extrema importância que todos os discursos sejam acompanhados, para que se examinem as novas construções ideológicas que estão circulando pela sociedade brasileira após todas essas significativas mudanças. 


\section{Referências Bibliográficas}

ARAUJO, D. P. de. "Inclusão com mérito" e as facetas do racismo institucional nas universidades estaduais de São Paulo. Revista Direito e Práxis, Rio de Janeiro, v. 10, n. 3, p. 2182-2213, set. 2019.

BARBOSA, L. Meritocracia e Sociedade Brasileira. RAE - Revista de Administração de Empresas, São Paulo, v. 54, n. 1, p. 80-85, jan./fev. 2014.

BASTOS, L.; BIAR, L. Análise de narrativa e práticas de entendimento da vida social. Delta, n. 31 especial, p. 97-126, 2015.

BAKHTIN, M. Marxismo e Filosofia da Linguagem. Tradução de Michel Lahud e Yara Frateschi Vieria. 5. ed. São Paulo: Hucitec, 1990.

. Os gêneros do discurso. In: Estética da criação verbal. p. 261306. São Paulo, Martins Fontes, 2003.

BENTO, M. A. S. Branqueamento e branquitude no Brasil. In: CARONE, I.; BENTO, M. A. S. (orgs). Psicologia social do racismo: Estudos sobre a branquitude e branqueamento no Brasil. 6. ed. Rio de Janeiro: Vozes, 2014.

BIAR, L. Demarcando território? Situando a Linguística Aplicada indisciplinar. In: Linguagem em (re)vista, ano 6, n. 10, 2009.

Trabalho de face e estigma no encontro interacional misto: um estudo de polidez aplicado ao contexto prisional. In: Linguística, Montevideo, v. 31, n. 01. p. 127-142, 2º sem. 2015.

BLOMMAERT, J. The sociolinguistics of Globalization. Cambridge: Cambridge University Press, 2010.

BORGES, T. R. S. Por um sentir crítico: um olhar feminista interseccional sobre a socioconstrução de identidades sociais de gênero, raça/etnia e classe de professoras de línguas. 2017. 232 p. Dissertação (Mestrado) Pontifícia Universidade Católica do Rio de Janeiro, 2017.

BRASIL. Lei no 9.394, de 20 de dezembro de 1996. Estabelece as diretrizes e bases da educação nacional. Diário Oficial da República Federativa do Brasil, Brasília, DF, 23 dez. 1996.

BRASIL. Lei $n^{\circ} 12.711$, de 29 de agosto de 2012. Dispõe sobre o ingresso nas universidades federais e nas instituições federais de ensino técnico de 
nível médio e dá outras providências. Diário Oficial da República Federativa do Brasil, Brasília, DF, 30 ago. 2012.

BRUNER, J. Atos de significação. Porto Alegre: Artes Médicas, 1997.

CAVALCANTI, I. T. N. et al. Desempenho acadêmico e o sistema de cotas no ensino superior: evidência empírica com dados da Universidade Federal da Bahia. Avaliação (Campinas), Sorocaba, v. 24, n. 1, p. 305-327, maio 2019.

CHANG, $\mathrm{H}$. Autoethnography as Method. Walnut Creek, CA: Left Coast Press, 2008.

CRESWELL, J. W. Projeto de pesquisa: métodos qualitativo, quantitativo e misto. Porto Alegre: Artmed, 2007.

DENZIN, N.; LINCOLN, Y. A Disciplina e a Prática da Pesquisa Qualitativa. In: DENZIN, N.; LINCOLN, Y. O Planejamento da Pesquisa Qualitativa: teorias e abordagens. Porto Alegre: Artmed, 2006.

ELLIS, C.; ADAMS, T. E.; BOCHNER, A. P. Auto Ethnography: An Overview. Historical Social Research, v. 36, p. 273- 290, 2011.

FAIRCLOUGH, N. Critical Discourse Analysis: The Critical Study of Language. London: Longman, 2010.

FABRICIO, B. F.; BASTOS, L. C. Narrativas e identidade de grupo: a memória como garantia do "nós" perante o "outro". In: PEREIRA, M. G. D.; BASTOS, C. R. P.; PEREIRA, T. C. (orgs.). Discursos socioculturais em interação. Interfaces entre a narrativa, a conversação e a argumentação. Rio de Janeiro: Garamond, 2009. p. 39-66.

FOUCAULT, M. A Arqueologia do Saber. Petrópolis: Vozes, Lisboa: Centro do Livro Brasileiro, 1972.

FOUCAULT. A ordem do discurso. Aula inaugural no Collège de France, pronunciada em 2 de dezembro de 1970. 3. ed. Tradução de Laura Fraga de Almeida Sampaio. São Paulo: Loyola, 1996. 79 p. Título original: L’ordre du discours. Leçon inaugurale au Collège de France prononcée le 2 décembre 1970.

FRIGOTTO, G. Trabalho Como Princípio Educativo: por uma superação das ambiguidades. In: Boletim Técnico do Senac, Ano 11, n. 3, p. 175192, set.-dez. 1985.

GARCEZ, P. M. Deixa eu te contar uma coisa: o trabalho sociológico de narrar na conversa cotidiana. In: RIBEIRO, B. T.; LIMA, C. C.; DANTAS, M. T. L. (orgs.). Narrativa, Identidade e Clínica. Rio de Janeiro: Edições IPUB, 2001. 
GEE, J. P. An Introduction to Discourse Analysis: Theory and Method. London: Routledge, 2000.

GEORGAKOPOULOU, A. Narrative Performances: A study of Modern Greek storytelling. Amsterdam/Philadelphia: John Benjamins, 1997.

GOFFMAN, E. Estigma: notas sobre a manipulação da identidade deteriorada. Tradução de Márcia Bandeira de Mello Leite Nunes. 4. ed. Rio de Janeiro: Livros Técnicos e Científicos, 1988.

Ritual de Interação: ensaios sobre o comportamento face a face, tradução de Fábio Rodrigues da Silva, 2. ed. Petrópolis: Vozes, 2011.

. The frame analysis of talk. In: Frame Analysis - an essay on the organization of experience. Boston: Harper \& Row, 1986.

GUERRINI, D. et al. Acesso e democratização do ensino superior com a Lei no 12.711/2012: o câmpus de Londrina da Universidade Tecnológica Federal do Paraná (UTFPR). Revista Brasileira de Estudos Pedagógicos, Brasília, v. 99, n. 251, p. 17-36, jan. 2018.

HALLIDAY, M. Introduction to functional grammar. London: Hodder Arnold, 1985.

HOELTGEBAUM, K. F. K.; GODOI, C. K.; LENZI, F. C. Discussão e Prática da Autoetnografia: um estudo sobre aprendizagem organizacional em uma situação de catástrofe. Revista Gestão Organizacional (Online), v. 5, p. 000, 2012.

HOLANDA, B. de. Raízes do Brasil. 26. ed. São Paulo: Companhia das Letras, 1995.

LABOV, W. The transformation of experience in narrative syntax. In: Language in the Inner City. University of Pennsylvania Press, 1972.

LEMOS, I. B. Narrativas de cotistas raciais sobre suas experiências na universidade. Revista Brasileira de Educação, Rio de Janeiro, v. 22, n. 71, e227161, 2017.

LINDE, C. Life Stories: The creation of coherence. USA: Oxford, 1993.

Evaluation as Linguistic Structure and Social Practice. In: GUNNARSSON, B. L.; LINNEL, P.; NORDBERG, B. (eds.). The Construction of Professional Discourse. London: Longman, 1997. p. 151-172.

LIMA, F. F. Formas da persuasão e manifestação das ideologias no noticiário da mídia impressa paulista sobre as eleições. Filologia e Linguística Portuguesa, Brasil, v. 15, n. 1, p. 127-153, mar. 2014. 
LITTLER, J. Against Meritocracy. Culture, power and myths of mobility. London: Routledge, 2018.

LOPES, L. P. M. Contemporaneidade e construção do conhecimento na área de estudos linguísticos. SCRIPTA, Belo Horizonte, v. 7, n. 14, p. 159$171,1^{\circ}$ sem. 2004.

MAGALHÃES, C. E. A.; NÓBREGA, A. N. A Construção Identitária do Professor Coordenador de Inglês: negociação e apresentação social na interação. Calidoscopio, São Leopoldo, v. 14, p. 79-91, 2016.

MEDINA, P. R. G. Do Bacharelismo à Bacharelice: Reflexos desses fenômenos nos cursos jurídicos, ao longo do tempo. In: Ensino Jurídico, Literatura e Ética. Brasília: OAB Editora, 2009.

MANZINI, E. J. A Entrevista na Pesquisa Social. Didática, São Paulo, v. 26/27, p. 149-158, 1990/1991.

MARTIN, J.; WHITE, P. The language of evaluation: appraisal in English. New York/Hampshire: Palgrave Macmillan, 2005.

MARQUES, E. P. de S. O acesso à educação superior e o fortalecimento da identidade negra. Revista Brasileira de Educação, Rio de Janeiro, v. 23, e230098, 2018.

MELO, G. C. V; LOPES, L. P. M. "Você é uma morena muito bonita": a trajetória textual de um elogio que fere. Trabalhos em Linguística Aplicada, Campinas, n. 54, v. 1, p. 53-78, jun. 2015.

MILLER, J.; GLASSNER, B. The 'inside' and the 'outside'. Finding realities in interviews. In: SILVERMAN, D. (ed.): Qualitative Research. Theory, method and practice. London: Sage, 1997. p. 99-112.

MINAYO, M. C. S. Amostragem e Saturação em Pesquisa Qualitativa: consensos e controvérsias. Revista Pesquisa Qualitativa, São Paulo, v. 5, n. 7, p. 01-12, abril. 2017.

MISHLER, E.G. Research Interviewing: context and narrative. Cambridge, MA: Harvard University Press, 1991.

. Narrativa e identidade: a mão dupla do tempo. In: LOPES, L. P. M.; BASTOS, L. C. (eds.) Identidades: recortes multi e interdisciplinares. Campinas: Mercado de Letras, 2002.

MOEHLECKE, S. Ação afirmativa no ensino superior: entre a excelência e a justiça racial. Educação Social, Campinas, v. 25, n. 88, p. 757-776, out. 2004.

NÓBREGA, A. N. Narrativas e avaliação no processo de construção do conhecimento pedagógico: abordagem sociocultural e sociossemiótica. 
2009. 244 p. Tese (Doutorado) - Pontifícia Universidade Católica do Rio de Janeiro, Rio de Janeiro, RJ, 2009.

NÓBREGA, A. N.; ABREU, A. R. Análise crítica da construção de identidades na prática escrita escolar. Calidoscopio, São Leopoldo, v. 13, p. 251-263, 2015.

PÁDUA, E. M. Metodologia da Pesquisa: abordagem teórico-prática. Campinas, São Paulo: Editora Papirus, 2004.

PAULA, M. F. C. Políticas de democratização da educação superior brasileira: limites e desafios para a próxima década. Avaliação (Campinas), Sorocaba, v. 22, n. 2, p. 301-315, ago. 2017.

PEDROTTI, A. S. "Era um inferno": análise narrativa da construção discursiva da emoção do professor e suas reflexões avaliativas sobre os sistemas municipal e federal de ensino. Revista Contraponto, Rio Grande do Sul, v. 6, p. 22-39, 2019.

PEDROTTI, A. S.; TEIXEIRA, J. C. G. Políticas de Permanência em Foco: Análise de desempenho acadêmico dos alunos ingressantes. In: ENCONTRO INTERCAMPI DE EDUCAÇÃO PROFISSIONAL, 1., 2017, Rio de Janeiro. Anais [....] Rio de Janeiro: CEFET, 2017.

QUEIROZ, Z. C. L. S. et al. A lei de cotas na perspectiva do desempenho acadêmico na Universidade Federal de Uberlândia. Revista Brasileira de Estudos Pedagógicos, Brasília, v. 96, n. 243, p. 299-320, ago. 2015.

RABELO, A. O. A importância da investigação narrativa na Educação. Educação e Sociedade, Campinas, v. 32, n. 114, p.171-188, 2011.

RIBEIRO, D. O que é Lugar de Fala? Belo Horizonte: Letramento, Justificando, 2017. 112 p. (Feminismos Plurais)

RIESSMAN, C. K. Narrative Methods for the Human Sciences. California: Sage Publication, 2008.

Narrative analysis. Series, n. 30. Newbury Park, CA: Sage, 1993.

RODRIGUES, A. D. O Discurso Mediático. Lisboa: Mimeo, 1996.

SANTOS, A. F. "Eu era empregado, agora sou patrão": análise narrativa de testemunhos alinhados à teologia da prosperidade. 2016. 138 p. Dissertação (Mestrado) - Pontifícia Universidade Católica do Rio de Janeiro, Rio de Janeiro, RJ. 2016.

SAVIANI, D. Sobre a Concepção de Politecnia. Rio de Janeiro: Politécnico da Saúde Joaquim Venâncio/Fiocruz-EPSJV, 1989. 
SAVIANI, D. O trabalho como princípio educativo frente às novas tecnologias. In: Novas tecnologias, trabalho e educação. Petrópolis/RJ: Vozes, 1994.

SILVEIRA, Z. S. da. Concepção de Educação Tecnológica na Reforma do Ensino Médio e Técnico no Governo FHC: resultado de um processo histórico. Revista Trabalho Necessário, [s. I.], v. 6, n. 6, jun. 2008.

SCHNACK, C.; PISONI, T.; OSTERMANN, A. Transcrição de Fala: do evento real à representação escrita. Entrelinhas, [s. I.], v. 2, n. 2. 2005.

SOARES, M. L. S. O Sistema de Cotas Raciais nas Universidades: uma análise comparativa entre as interpretações populares sobre a política de cotas e a realidade a partir da experiência dos cotistas de odontologia da universidade Estadual do Rio de Janeiro. 2014. 130 p. Dissertação (Mestrado) - Centro Federal de Educação Tecnológica Celso Suckow da Fonseca, Rio de Janeiro, RJ, 2014.

TREVISOL, J. V.; NIEROTKA, R. L. Os jovens das camadas populares na universidade pública: acesso e permanência. Revista Katálysis, Florianópolis, v. 19, n. 1, p. 22-32, jun. 2016.

VAN DIJK, T. A. How Globo media manipulated the impeachment of Brazilian President Dilma Rousseff. Discourse \& Communication, Barcelona, v. 11, n. 2, p. 199-229, 2017.

WHITE, P. Valoração: a linguagem da avaliação e da perspectiva. In: Linguagem em (Dis)curso, Tubarão, v. 4, n. especial, p. 178-205, 2004.

WINK, G. "Looking for more Brazilian solutions": Rhetorical Strategies against Racial Quotas in Brazilian Higher Education. Brasiliana: Journal for Brazilian Studies, London, v. 6, n. 2, p. 3-41, 2018.

WODAK, R. et al. The Discursive Construction of National Identity. $2^{\text {nd }}$. ed. Edinburgh University Press, 2009.

YOUNG, M. The Rise of the Meritocracy 1870-2033: An essay on education and society. London: Thames and Hudson, 1958. 


\section{8 \\ Anexo A \\ Convenções de Transcrição}

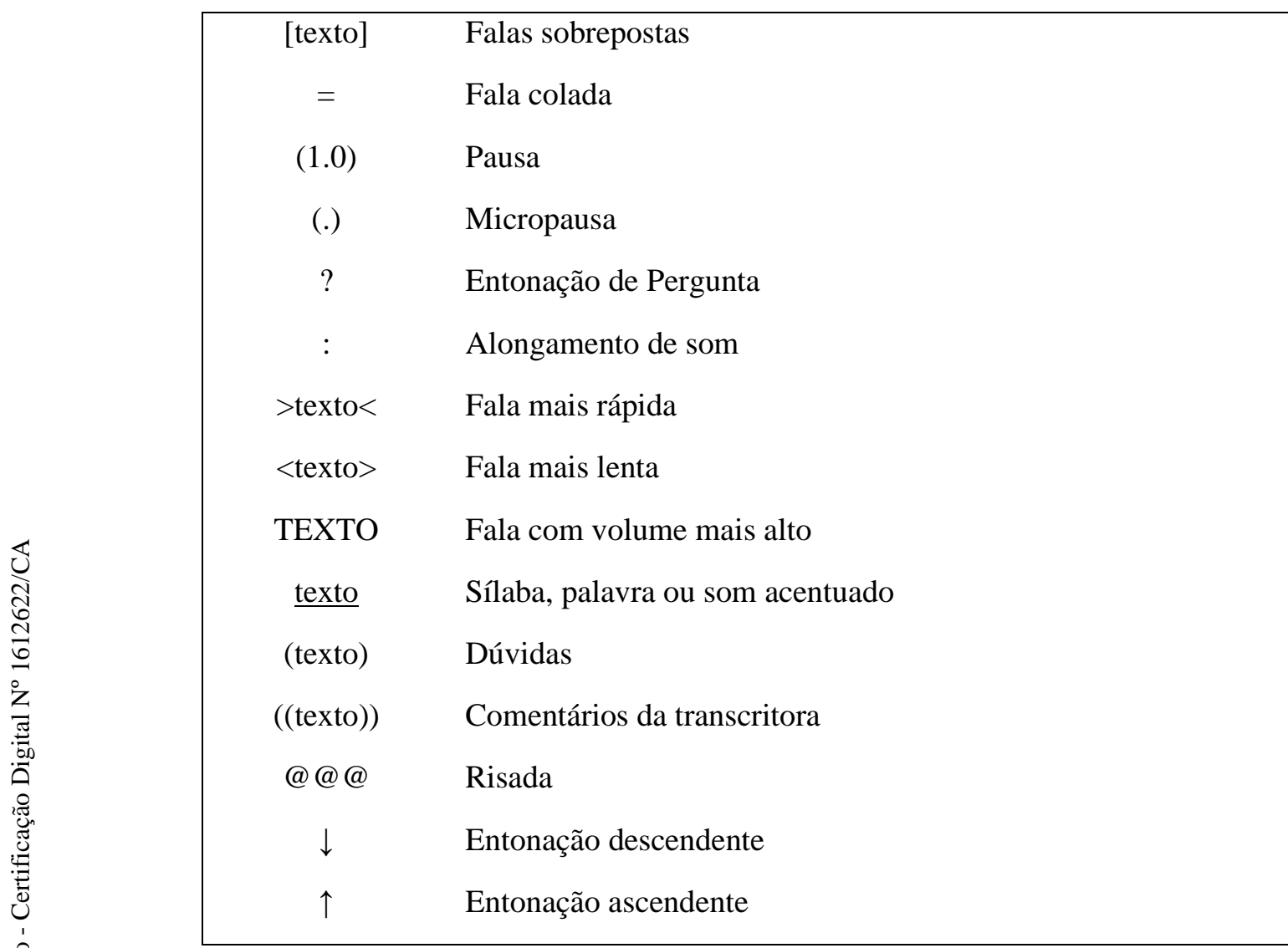

As convenções utilizadas nas narrativas desta pesquisa foram baseadas nos estudos de Análise da Conversação (Sacks, Schegloff e Jefferson, 1974). O quadro está por mim adaptado ao que foi utilizado nesta tese. 


\section{9 \\ Anexo B \\ Roteiros das entrevistas com alunos e com docentes}

\section{Roteiro de Entrevista}

ALUNA/O

1) Você entrou no CEFET pela política de cotas? Se sim, qual grupo?

2) Você concorda com a política de cotas?

3) Você acha que os alunos que acessam pela política de cotas têm tratamento diferenciado? Como?

4) Você já vivenciou ou presenciou situações de desrespeito/racismo, dentro do espaço escolar, com as/os alunas/os que acessam pela política de cotas?

5) Se sim, por parte de quem? Alunas/os, professoras/es, outras/os? Lembra-se de alguma para contar?

6) Por que você acha que isto acontece?

7) As mesmas situações ou tratamentos desrespeitosos ocorrem com os grupos de cotas não raciais também?

8) O que você acha dos programas que constituem a política de permanência para as/os alunas/os do CEFET/RJ?

9) Em uma visão de fora da gerência educacional, você acha que a evasão de alunas/os que acessam pela política de cotas é maior do que os demais?

10) Você acha que houve avanço neste estigma imposto às/aos alunas/os após a $1^{\underline{a}}$ turma formada no sistema integrado?

11) Tem alguma ideia para que o CEFET/RJ consiga melhorar a permanência (acadêmica e social) dos alunos que acessam pela política de cotas? 


\section{Roteiro de Entrevista \\ PROFESSORA/OR}

1) Quando você soube que iriam entrar alunos através da política de cotas, o que você sentiu/pensou?

2) Você pensou em alguma modificação em sua prática docente, metodologias ou currículo geral? E sua coordenação?

3) Você acha que há alguma diferença entre os alunos que acessam pelo grupo de ampla concorrência e pelos grupos de cotas?

4) Você já presenciou alguma situação de racismo ou discriminações ou em sala de aula ou dentro da coordenação ou em qualquer espaço escolar? Se não presenciou, soube?

5) Ao final desse período de finalização de um ciclo de formação, você é contra ou a favor da política de cotas? 


\section{Anexo C}

\section{Termos de consentimento livre e esclarecido}

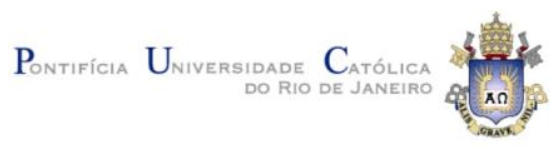

\begin{tabular}{l}
\hline TERMO DE CONSENTIMENTO LIVRE E ESCLARECIDO - DOCENTE \\
\hline DELIMITAÇÃO DO PROJETO DE PESQUISA E AGRADECIMENTO PELA PARTICIPAÇÃO \\
Você está sendo convidada(o) como voluntária(o) a participar do estudo: "Acabou a Qualidade da Escola": \\
construção de estigma em narrativas sobre cotas de ingresso no CEFET/RJ, objeto de pesquisa de doutorado \\
em Estudos da Linguagem, pela Pontificia Universidade Católica, que tem como objetivo a identificação, através \\
das narrativas, do modo como os discursos influenciam no estigma e na formação identitária dos alunos do ensino \\
técnico integrado ao médio do CEFET/RJ, bem como a formação de identidade institucional. Agradecemos a sua
\end{tabular} colaboração e delimitamos abaixo o compromisso desta pesquisa com a sua participação.

Seguindo o Art. $9^{\circ}$ do regulamento da comissão de ética, publicada através da RESOLUÇãO $\mathrm{N}^{\circ} 510$, DE 07 DE ABRIL DE 2016, são direitos dos participantes de uma pesquisa:

I - ser informado sobre a pesquisa;

Você tem o direito de ser informado de forma detalhada até que se esgotem suas dúvidas sobre o que estamos pesquisando.

II - desistir a qualquer momento de participar da pesquisa, sem qualquer prejuízo;

Você pode desistir de participar da pesquisa em qualquer momento e todos os dados referentes a você serão apagados.

III - ter sua privacidade respeitada;

Você tem o direito de não responder ou expor questões que ache que são privadas e sua decisão será respeitada em qualquer momento que solicitar.

IV - ter garantida a confidencialidade das informações pessoais;

Você tem o direito de solicitar a privacidade de seus dados, como nome e informações pessoais ou qualquer informação que possa identificar você nos dados gerados. As pesquisadoras se responsabilizam pela guarda e confidencialidade de seus dados.

V - decidir se sua identidade será divulgada e quais são, dentre as informações que forneceu, as que podem ser tratadas de forma pública;

Você tem o direito de escolher se sua identidade será divulgada e quais dados que forneceu podem ser publicados ou devem permanecer de modo confidencial.

VI - ser indenizado pelo dano decorrente da pesquisa, nos termos da Lei;

Caso ocorra algum dano decorrente da sua participação no estudo, você será devidamente indenizado, conforme determina a lei.

VII - o ressarcimento das despesas diretamente decorrentes de sua participação na pesquisa.

Caso você tenha qualquer despesa decorrente da participação na pesquisa, tais como transporte, alimentação entre outros, haverá ressarcimento dos valores gastos.

Pesquisadora: Allane de Souza Pedrotti Matos

Doutoranda em Estudos da Linguagem pela PUC-RIO

E-mail: allane_pedrotti@yahoo.com.br / Telefone: (21) 996549897

Orientadora: Liana Biar / E-mail: lianabiar@gmail.com / Telefone: (21) 98841-1418

DECLARAÇÃo

Declaro que li e entendi todas as informações presentes neste Termo de Consentimento Livre e Esclarecido e tive a oportunidade de discutir as informações deste termo. Todas as minhas perguntas foram respondidas e eu estou satisfeito com as respostas. Entendo que receberei uma via assinada e datada deste documento e que outra via assinada e datada será arquivada pelas pesquisadoras responsáveis pelo estudo.

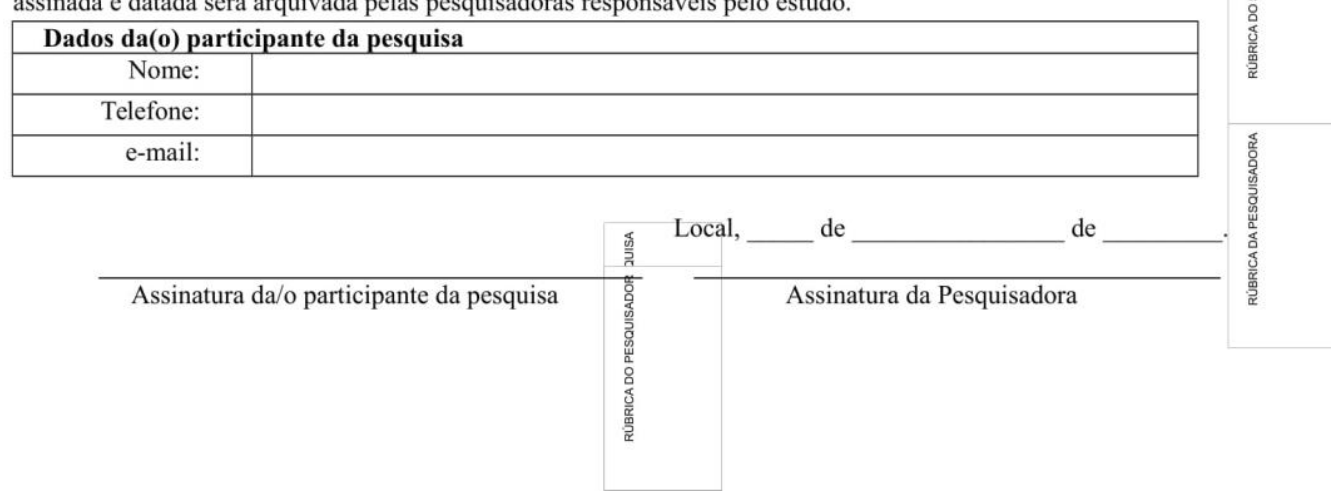


TERMO DE CONSENTIMENTO LIVRE E ESCLARECIDO - ALUNA/O MAIOR DELIMITAÇÃO DO PROJETO DE PESQUISA E AGRADECIMENTO PELA PARTICIPAÇÃO

Você está sendo convidada(o) como voluntária(o) a participar do estudo: "Acabou a Qualidade da Escola": construção de estigma em narrativas sobre cotas de ingresso no CEFET/RJ, objeto de pesquisa de doutorado em Estudos da Linguagem, pela Pontifícia Universidade Católica, que tem como objetivo a identificação, através das narrativas, do modo como os discursos influenciam no estigma e na formação identitária dos alunos do ensino técnico integrado ao médio do CEFET/RJ, bem como a formação de identidade institucional. Agradecemos a sua colaboração e delimitamos abaixo o compromisso desta pesquisa com a sua participação.

Seguindo o Art. $9^{\circ}$ do regulamento da comissão de ética, publicada através da RESOLUÇ̃̃O $\mathrm{N}^{\circ} 510, \mathrm{DE}$ 07 DE ABRIL DE 2016, são direitos dos participantes de uma pesquisa:

I - ser informado sobre a pesquisa;

Você tem o direito de ser informado de forma detalhada até que se esgotem suas dúvidas sobre o que estamos pesquisando.

II - desistir a qualquer momento de participar da pesquisa, sem qualquer prejuízo;

Você pode desistir de participar da pesquisa em qualquer momento e todos os dados referentes a você serão apagados.

III - ter sua privacidade respeitada;

Você tem o direito de não responder ou expor questões que ache que são privadas e sua decisão será respeitada em qualquer momento que solicitar.

IV - ter garantida a confidencialidade das informações pessoais;

Você tem o direito de solicitar a privacidade de seus dados, como nome e informações pessoais ou qualquer informação que possa identificar você nos dados gerados. As pesquisadoras se responsabilizam pela guarda e confidencialidade de seus dados.

V - decidir se sua identidade será divulgada e quais são, dentre as informações que forneceu, as que podem ser tratadas de forma pública;

Você tem o direito de escolher se sua identidade será divulgada e quais dados que forneceu podem ser publicados ou devem permanecer de modo confidencial.

VI - ser indenizado pelo dano decorrente da pesquisa, nos termos da Lei;

Caso ocorra algum dano decorrente da sua participação no estudo, você será devidamente indenizado, conforme determina a lei.

VII - o ressarcimento das despesas diretamente decorrentes de sua participação na pesquisa.

Caso você tenha qualquer despesa decorrente da participação na pesquisa, tais como transporte, alimentação entre outros, haverá ressarcimento dos valores gastos.

Pesquisadora: Allane de Souza Pedrotti Matos

\section{CONTATO}

Doutoranda em Estudos da Linguagem pela PUC-RIO

E-mail: allane_pedrotti@yahoo.com.br / Telefone: (21) 996549897

Orientadora: Liana Biar / E-mail: lianabiar@gmail.com / Telefone: (21) 98841-1418

DECLARAÇÃO

Declaro que li e entendi todas as informações presentes neste Termo de Consentimento Livre e Esclarecido e tive a oportunidade de discutir as informações deste termo. Todas as minhas perguntas foram respondidas e eu estou satisfeito com as respostas. Entendo que receberei uma via assinada e datada deste documento e que outra via assinada e datada será arquivada pelas pesquisadoras responsáveis pelo estudo.

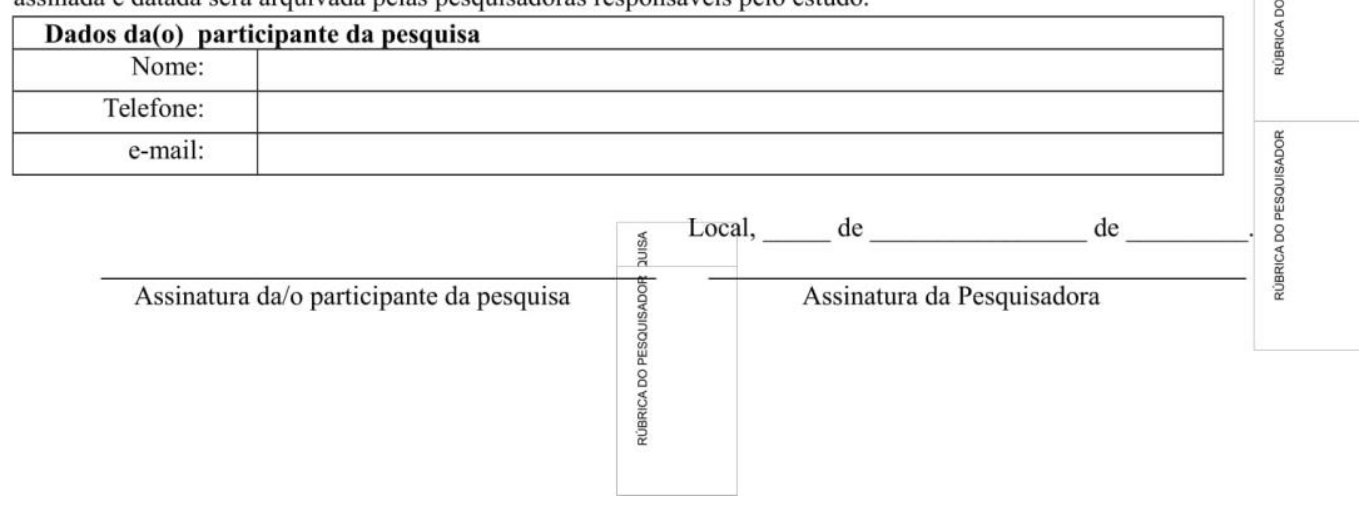




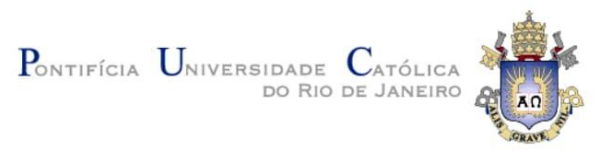

\section{\begin{tabular}{|c} 
TERMO DE ASSENTIMENTO - ALUNA/O MENOR DE IDADE \\
DELIMITAÇ̃̃O DO PROJETO DE PESQUISA E AGRADECIMENTO PELA PARTICIPAÇÃO
\end{tabular}}

Você está sendo convidada(o) como voluntária(o) a participar do estudo: "Acabou a Qualidade da Escola": construção de estigma em narrativas sobre cotas de ingresso no CEFET/RJ, objeto de pesquisa de doutorado em Estudos da Linguagem, pela Pontifícia Universidade Católica, que tem como objetivo a identificação, através das narrativas, do modo como os discursos influenciam no estigma e na formação identitária dos alunos do ensino técnico integrado ao médio do CEFET/RJ, bem como a formação de identidade institucional. Agradecemos a sua colaboração e delimitamos abaixo o compromisso desta pesquisa com a sua participação.

Seguindo o Art. $9^{\circ}$ do regulamento da comissão de ética, publicada através da RESOLUÇão $\mathrm{N}^{\circ}$ 510, DE 07 DE ABRIL DE 2016, são direitos dos participantes de uma pesquisa:

I - ser informado sobre a pesquisa;

Você tem o direito de ser informado de forma detalhada até que se esgotem suas dúvidas sobre o que estamos pesquisando.

II - desistir a qualquer momento de participar da pesquisa, sem qualquer prejuízo;

Você pode desistir de participar da pesquisa em qualquer momento e todos os dados referentes a você serão apagados.

III - ter sua privacidade respeitada;

Você tem o direito de não responder ou expor questões que ache que são privadas e sua decisão será respeitada em qualquer momento que solicitar.

IV - ter garantida a confidencialidade das informações pessoais;

Você tem o direito de solicitar a privacidade de seus dados, como nome e informações pessoais ou qualquer informação que possa identificar você nos dados gerados. As pesquisadoras se responsabilizam pela guarda e confidencialidade de seus dados.

V-decidir se sua identidade será divulgada e quais são, dentre as informações que forneceu, as que podem ser tratadas de forma pública;

Você tem o direito de escolher se sua identidade será divulgada e quais dados que forneceu podem ser publicados ou devem permanecer de modo confidencial.

VI - ser indenizado pelo dano decorrente da pesquisa, nos termos da Lei;

Caso ocorra algum dano decorrente da sua participação no estudo, você será devidamente indenizado, conforme determina a lei.

VII - o ressarcimento das despesas diretamente decorrentes de sua participação na pesquisa.

Caso você tenha qualquer despesa decorrente da participação na pesquisa, tais como transporte, alimentação entre outros, haverá ressarcimento dos valores gastos.

Pesquisadora: Allane de Souza Pedrotti Matos

CONTATO

Doutoranda em Estudos da Linguagem pela PUC-RIO

E-mail: allane_pedrotti@yahoo.com.br / Telefone: (21) 996549897

Orientadora: Liana Biar / E-mail: lianabiar@gmail.com / Telefone: (21) 98841-1418

DECLARAÇão

Declaro que li e entendi todas as informações presentes neste Termo de Consentimento Livre e Esclarecido e tive a oportunidade de discutir as informações deste termo. Todas as minhas perguntas foram respondidas e eu estou satisfeito com as respostas. Entendo que receberei uma via assinada e datada deste documento e que outra via assinada e datada será arquivada pelas pesquisadoras responsáveis pelo estudo.

\begin{tabular}{|c|c|}
\hline \multicolumn{2}{|c|}{ Dados e assinatura de assentimento da/o aluna/o participante } \\
\hline Nome: & \\
\hline Telefone: & \\
\hline e-mail: & \\
\hline
\end{tabular}

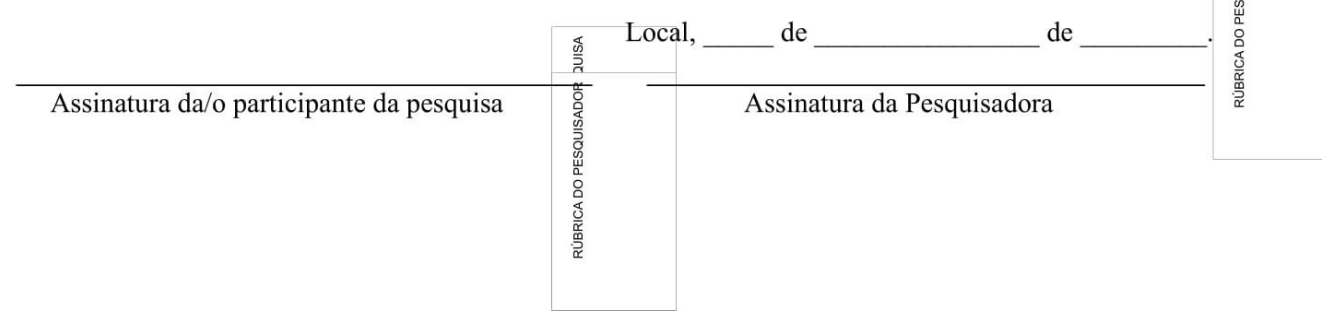




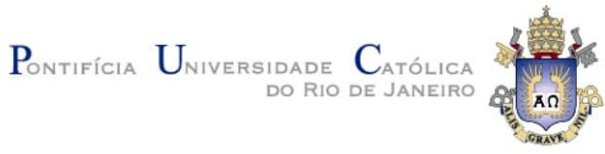

TERMO DE CONSENTIMENTO LIVRE E ESCLARECIDO - RESPONSÁVEL POR MENOR DELIMITAÇÃO DO PROJETO DE PESQUISA E AGRADECIMENTO PELA PARTICIPAÇÃO

Sua(seu) filha(o) está sendo convidada(o) como voluntária(o) a participar do estudo: "Acabou a Qualidade da Escola": construção de estigma em narrativas sobre cotas de ingresso no CEFET/RJ, objeto de pesquisa de doutorado em Estudos da Linguagem, pela Pontifícia Universidade Católica, que tem como objetivo a identificação, através das narrativas, do modo como os discursos influenciam no estigma e na formação identitária dos alunos do ensino técnico integrado ao médio do CEFET/RJ, bem como a formação de identidade institucional. Agradecemos a sua colaboração e delimitamos abaixo o compromisso desta pesquisa com a participação dela(dele). Seguindo o Art. $9^{\circ}$ do regulamento da comissão de ética, publicada através da RESOLUÇÃO N $^{\circ}$ 510, DE 07 DE ABRIL DE 2016, são direitos dos participantes de uma pesquisa:

I - ser informado sobre a pesquisa;

Você e sua(seu) filha(o) têm o direito de serem informadas(os) de forma detalhada até que se esgotem as dúvidas sobre o que estamos pesquisando.

II - desistir a qualquer momento de participar da pesquisa, sem qualquer prejuízo;

Você e sua(seu) filha(o) podem desistir de participar da pesquisa em qualquer momento e todos os dados serão apagados.

III - ter sua privacidade respeitada;

Sua(seu) filha(o) tem o direito de não responder ou expor questões que ache que são privadas e esta decisão será respeitada em qualquer momento que solicitar.

IV - ter garantida a confidencialidade das informações pessoais;

Você e sua(seu) filha(o) têm o direito de solicitar a privacidade dos dados, como nome e informações pessoais ou qualquer informação que possa identificá-la(o) nos dados gerados. As pesquisadoras se responsabilizam pela guarda e confidencialidade dos dados.

V - decidir se sua identidade será divulgada e quais são, dentre as informações que forneceu, as que podem ser tratadas de forma pública;

Você e sua(seu) filha(o) têm o direito de escolher se a identidade será divulgada e quais dados que forneceu podem ser publicados ou devem permanecer de modo confidencial.

VI - ser indenizado pelo dano decorrente da pesquisa, nos termos da Lei;

Caso ocorra algum dano decorrente da participação no estudo, vocês serão devidamente indenizados, conforme determina a lei.

VII - o ressarcimento das despesas diretamente decorrentes de sua participação na pesquisa.

Caso vocês tenham qualquer despesa decorrente da participação na pesquisa, tais como transporte, alimentação entre outros, haverá ressarcimento dos valores gastos.

CONTATO: Pesquisadora: Allane de Souza Pedrotti Matos - Doutoranda em Estudos da Linguagem pela PUCRIO / E-mail: allane_pedrotti@yahoo.com.br / Telefone: (21) 996549897 / Orientadora: Liana Biar / E-mail lianabiar@gmail.com / Telefone: (21) 98841-1418

DECLARAÇÃo: Declaro que li e entendi todas as informações presentes neste Termo de Consentimento Livre e Esclarecido e tive a oportunidade de discutir as informações deste termo. Todas as minhas perguntas foram respondidas e eu estou satisfeito com as respostas. Entendo que receberei uma via assinada e datada deste documento e que outra via assinada e datada será arquivada pelas pesquisadoras responsáveis pelo estudo.

\begin{tabular}{|l|l|}
\hline \multicolumn{2}{|c|}{ Dados e assinatura de autorização da(o) responsável pela(o) aluna(o) menor } \\
\hline Nome da(o)responsável: & \\
\hline Nome da aluna(o) menor: & \\
\hline Telefone e e-mail: & \\
\hline Assinatura de autorização & \\
\hline
\end{tabular}

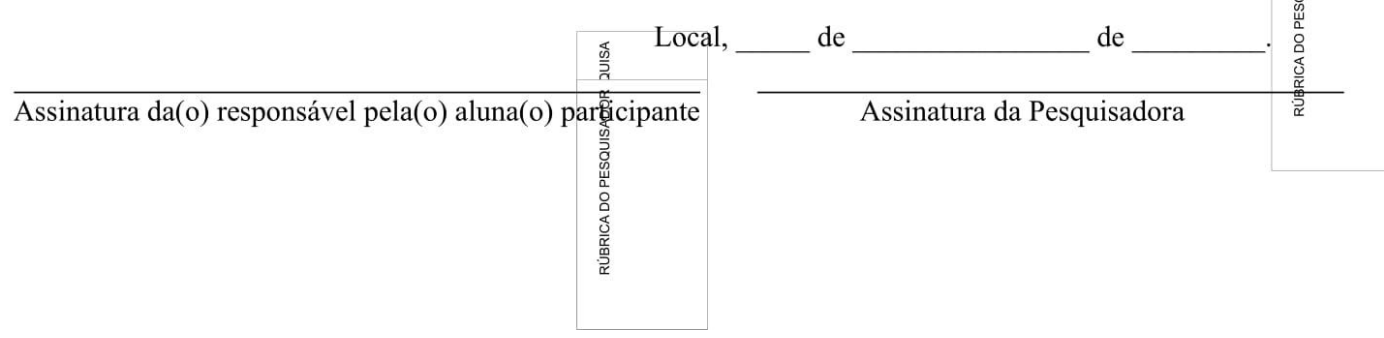

